\title{
Air Toxic Emissions from the Combustion of Coal: Identifying and Quantifying Hazardous Air Pollutants from U.S. Coals
}

by C.B. Szpunar

Environmental Assessment and Information Sciences Division, Argonne National Laboratory, 9700 South Cass Avenue, Argonne, Illinois 60439 


\section{CONTENTS}

NOTATION $\ldots \ldots \ldots \ldots \ldots \ldots \ldots \ldots \ldots \ldots \ldots \ldots \ldots \ldots \ldots \ldots \ldots \ldots$

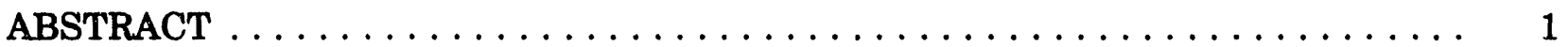

1 INTRODUCTION $\ldots \ldots \ldots \ldots \ldots \ldots \ldots \ldots \ldots \ldots \ldots \ldots \ldots \ldots \ldots$

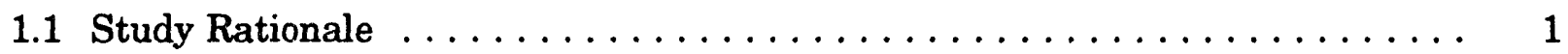

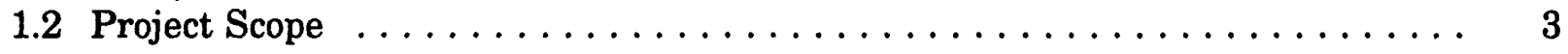

2 IDENTIFICATION OF HAZARDOUS AIR POLLUTANTS FROM COAL $\ldots \ldots \ldots$

2.1 Trace Elements . . . . . . . . . . . . . . . . . . . . . . 5

2.1.1 Hazardous Air Pollutants Identified by

U.S. Government Agencies . . . . . . . . . . . . . . . 5

2.1.2 Hazardous Air Pollutants Identified by Nongovernment

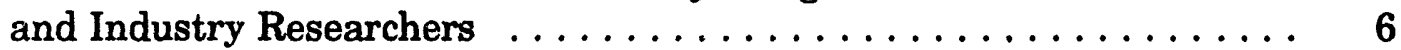

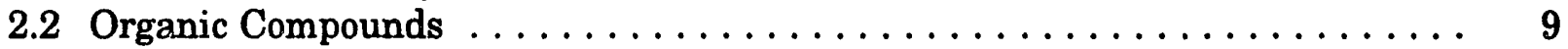

3 DESCRIPTION OF COAL COMPONENTS AND COMPOUNDS DERIVED FROM COAL CONTRIBUTING TO HAZARDOUS AIR POLLUTANTS . . . . . . . 15

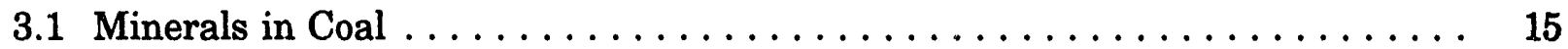

3.2 Trace Elements Inherent in Coal $\ldots \ldots \ldots \ldots \ldots \ldots \ldots$

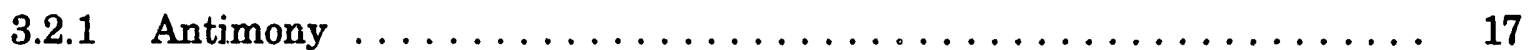

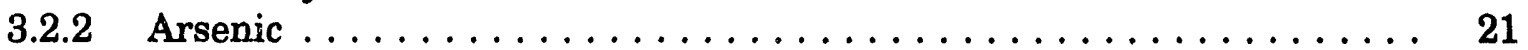

3.2 .3 Beryllium ........................... 23

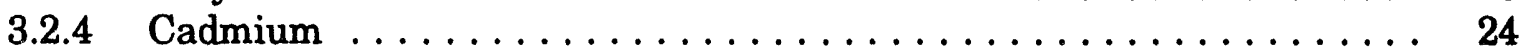

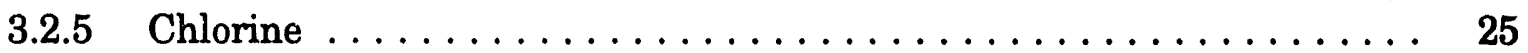

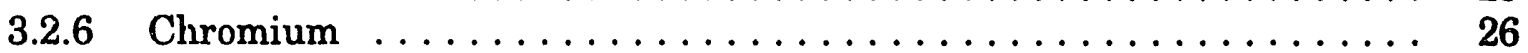

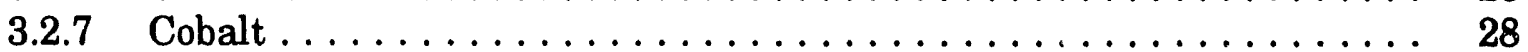

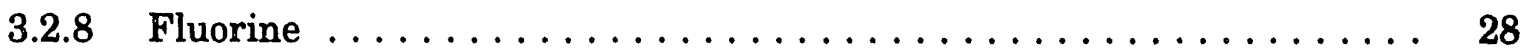

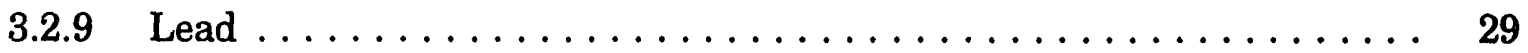

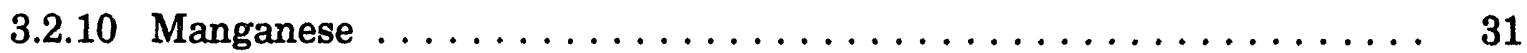

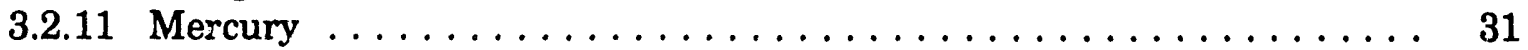

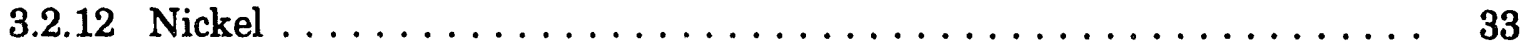

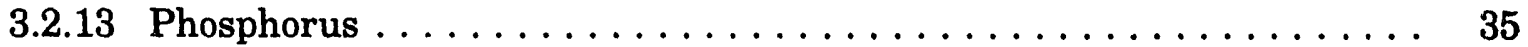

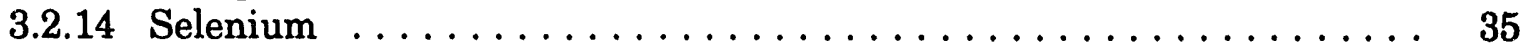

3.2 .15 Radionuclides ............................ 37

3.3 Organic Compounds Derived from Coal upon Combustion . . . . . . . . . . . . 40

3.3.1 Acetaldehyde ............................. 40

3.3 .2 Benzene ............................ 41

3.3.3 Benzidine ........................... 41

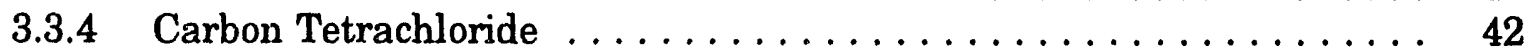

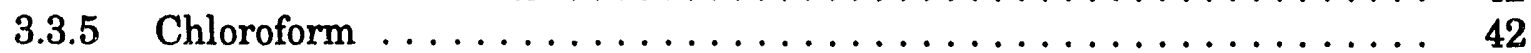

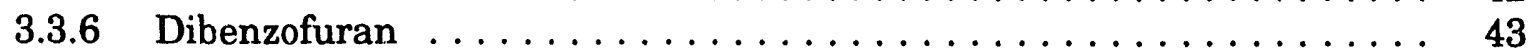

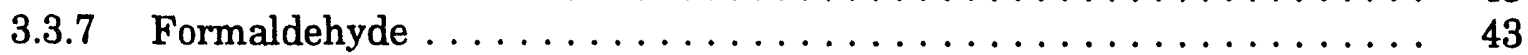

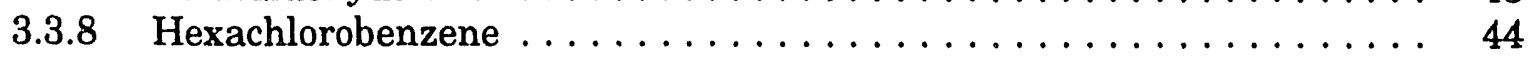




\section{CONTENTS (Cont.)}

3.3.9 Naphthalene $\ldots \ldots \ldots \ldots \ldots \ldots \ldots \ldots \ldots \ldots \ldots \ldots \ldots \ldots, 44$

3.3.10 Phenol ............................ 45

3.3.11 Polycyclic Aromatic Hydrocarbons . . . . . . . . . . . . . . 45

3.3.12 2,3,7,8-Tetrachlorodibenzo-p-dioxin $\ldots \ldots \ldots \ldots \ldots \ldots \ldots \ldots, 46$

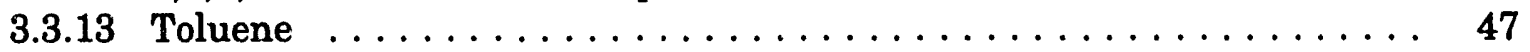

3.3.14 Trichloroethylene $\ldots \ldots \ldots \ldots \ldots \ldots \ldots \ldots \ldots \ldots \ldots \ldots, 47$

4 CHARACTERIZATION OF TRACE ELEMENTS IN U.S. COAL BY RANK AND REGION $\ldots \ldots \ldots \ldots \ldots \ldots \ldots \ldots \ldots \ldots \ldots, 49$

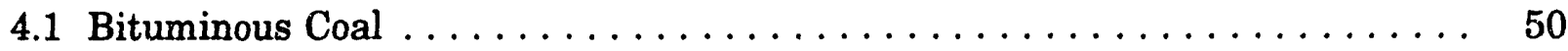

4.1.1 Appalachian Bituminous Coal $\ldots \ldots \ldots \ldots \ldots \ldots \ldots \ldots \ldots, 50$

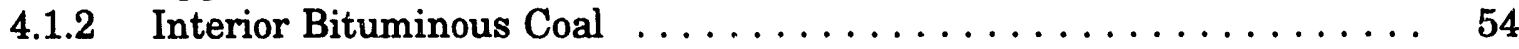

4.1.3 Rocky Mountain Bituminous Coal $\ldots \ldots \ldots \ldots \ldots \ldots \ldots \ldots \ldots, \ldots \ldots$

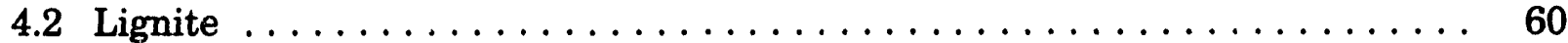

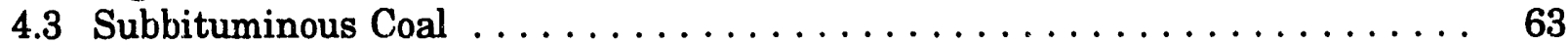

4.4 Anthracite . . . . . . . . . . . . . . . . . . . . . 64

4.5 Trace Elemental Highlights by Coal Rank and Region $\ldots \ldots \ldots \ldots \ldots \ldots 65$

4.6 Trace Elements in U.S. Coal Ash $\ldots \ldots \ldots \ldots \ldots \ldots \ldots \ldots \ldots \ldots, \ldots \ldots$

5 EFFECTS OF COMBUSTION ON THE TRACE ELEMENTS IN COAL $\ldots \ldots \ldots 73$

5.1 Combustion Types and Trace Element Emissions .............. 74

5.2 Classification of the Trace Elements - Partitioning ............ 75

6 PROJECTED TRACE ELEMENT HAZARDOUS AIR

POLLUTANT EMISSIONS $\ldots \ldots \ldots \ldots \ldots \ldots \ldots \ldots \ldots \ldots \ldots \ldots, 79$

6.1 Appalachian Bituminous Coal $\ldots \ldots \ldots \ldots \ldots \ldots \ldots \ldots \ldots \ldots \ldots, 80$

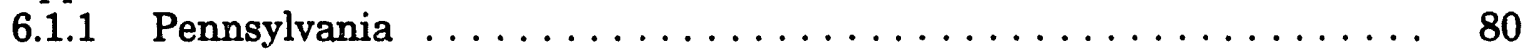

$6.1 .2 \quad$ Eastern Kentucky $\ldots \ldots \ldots \ldots \ldots \ldots \ldots \ldots \ldots \ldots \ldots \ldots, 82$

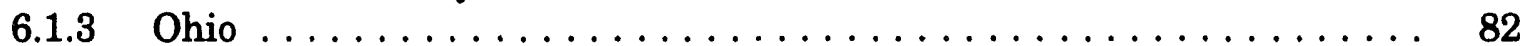

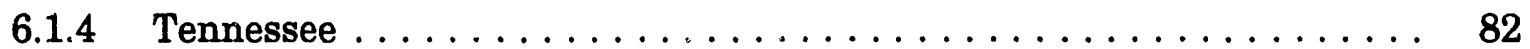

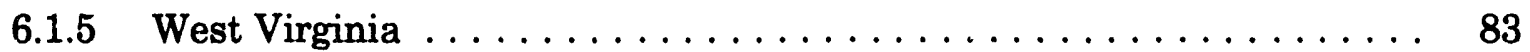

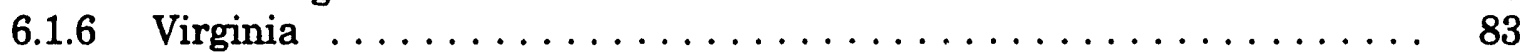

6.2 Interior Bituminous Coal $\ldots \ldots \ldots \ldots \ldots \ldots \ldots \ldots \ldots \ldots \ldots \ldots$

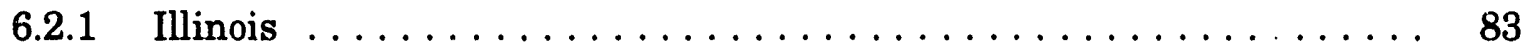

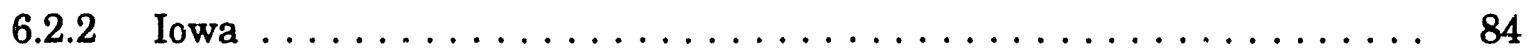

6.2 .3 Missouri $\ldots \ldots \ldots \ldots \ldots \ldots \ldots \ldots \ldots \ldots \ldots \ldots \ldots \ldots, 84$

6.2 .4 Oklahoma $\ldots \ldots \ldots \ldots \ldots \ldots \ldots \ldots \ldots \ldots \ldots \ldots \ldots \ldots$

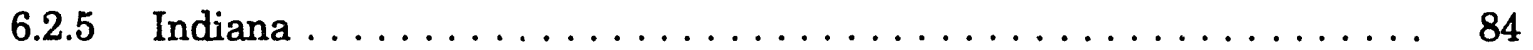

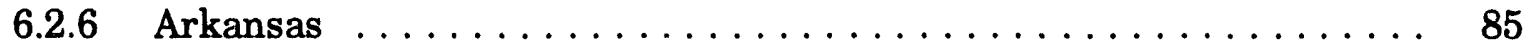

6.3 Rocky Mountain Bituminous Coal $\ldots \ldots \ldots \ldots \ldots \ldots \ldots \ldots \ldots \ldots$

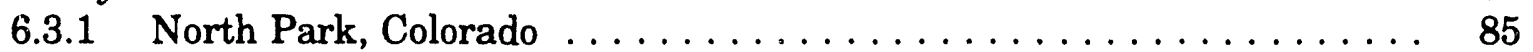

6.3.2 Hanna, Wyoming . . . . . . . . . . . . . . . . . 85

6.3.3 Black Mesa, Arizona $\ldots \ldots \ldots \ldots \ldots \ldots \ldots \ldots \ldots \ldots \ldots \ldots$

6.3 .4 Uinta, Utah . . . . . . . . . . . . . . . . . 86 


\section{CONTENTS (Cont.)}

6.4 Northern Plains Lignite and Subbituminous Coal . . . . . . . . . . 86

6.4 .1 North Dakota Lignite . . . . . . . . . . . . . . . . . 87

6.4 Wyoming Subbituminous Coal $\ldots \ldots \ldots \ldots \ldots \ldots \ldots \ldots \ldots$

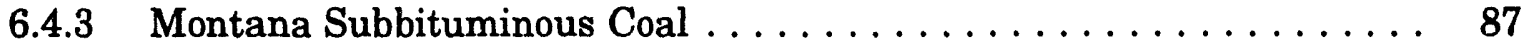

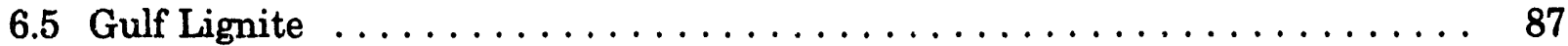

6.6 Alaskan Subbituminous Coal $\ldots \ldots \ldots \ldots \ldots \ldots \ldots$

6.7 Pennsylvanian Anthracite $\ldots \ldots \ldots \ldots \ldots \ldots \ldots \ldots \ldots \ldots$

7 MEASURED ORGANIC HAZARDOUS AIR POLLUTANT EMISSIONS $\ldots \ldots$. . 89

7.1 Identification and Quantification of Organic Emissions . . . . . . . . . 89

7.2 Organic Emissions by Plant Type and Type of Firing $\ldots \ldots \ldots \ldots \ldots$

8 HIGHLIGHTS AND FUTURE DIRECTIONS $\ldots \ldots \ldots \ldots \ldots \ldots$

APPENDIX A: Tables Listing the Calculated Annual Trace Element Emissions from a New, Modern, 500-MWe Power Plant Firing U.S. Coal . . . . 99

REFERENCES $\ldots \ldots \ldots \ldots \ldots \ldots \ldots \ldots \ldots \ldots \ldots \ldots \ldots \ldots \ldots \ldots$

BIBLIOGRAPHY $\ldots \ldots \ldots \ldots \ldots \ldots \ldots \ldots \ldots \ldots \ldots \ldots \ldots$

\section{TABLES}

1 Trace Elements: EPA- and DOE-Identified Hazardous Air Pollutants $\ldots \ldots \ldots$

2 Trace Elements of Environmental Interest $\ldots \ldots \ldots \ldots \ldots$

3 Organic Compounds: Hazardous Air Pollutants . . . . . . . . . . . . . . 10

4 Minerals in Coal $\ldots \ldots \ldots \ldots \ldots \ldots \ldots \ldots \ldots \ldots \ldots$

5 Trace Element Postcombustion Disposition $\ldots \ldots \ldots \ldots \ldots \ldots$

6 Elemental Ranges by U.S. Region and Coal Rank . . . . . . . . . . . . . . . 19

7 Elemental Average Concentrations and Calorific Values by U.S. Region

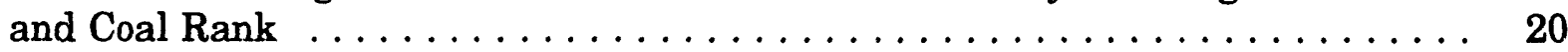

8 Typical Elemental Concentrations of Coal Burned in EEC Power Stations _. . . 21

9 U.S. Appalachian Bituminous Coal Elemental Average Concentrations and Calorific Value by State 


\section{TABLES (Cont.)}

10 U.S. Appalachian Bituminous Coal Elemental Concentration Ranges

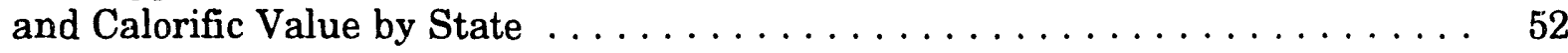

11 U.S. Elemental Average Coal Concentrations by Rank $\ldots \ldots \ldots \ldots \ldots \ldots$

12 U.S. Interior Bituminous Coal Elemental Average Concentrations and Calorific Value by State $\ldots \ldots \ldots \ldots \ldots \ldots \ldots \ldots \ldots \ldots$

13 U.S. Interior Bituminous Coal Elemental Concentration Ranges and Calorific Value by State $\ldots \ldots \ldots \ldots \ldots \ldots \ldots \ldots \ldots \ldots$

14 U.S. Rocky Mountain Bituminous Coal Elemental Average Concentrations and $\mathrm{C}$ lorific Value by State $\ldots \ldots \ldots \ldots \ldots \ldots \ldots \ldots \ldots \ldots \ldots \ldots$

15 U.S. Rocky Mountain Bituminous Coal Elemental Concentration Ranges and Calorific Value by Region .......................... 59

16 U.S. Lignite and Subbituminous Coal Elemental Average Concentrations and Calorific Value by State $\ldots \ldots \ldots \ldots \ldots \ldots \ldots \ldots \ldots \ldots \ldots$

17 U.S. Gulf and Northern Plains Lignite Elemental Concentration Ranges

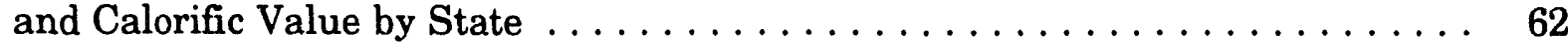

18 U.S. Northern Plains and Alaska Subbituminous Coal Elemental Concentration Ranges and Calorific Value by State ............... 63

19 U.S. Pennsylvania Anthracite Elemental Average Concentrations, Ranges, and Calorific Value ..........................

20 Highlighted Highest and Lowest U.S. Coal Elemental Average Concentrations and Ranges by Region and Rank ................ 66

21 Concentration Ranges of Trace Elements in U.S. Coal Ash $\ldots \ldots \ldots \ldots \ldots 72$

22 Assumed Simplified Emission Factors for HAP Trace Elements from Coal-Fired Power Plants . . . . . . . . . . . . . . . . . . . 80

23 Calculated Annual Significant Trace Element Emissions from a New 500-MWe Power Plant Firing U.S. Coal . . . . . . . . . . . . . . 81

24 Significant Organic Emissions Measured from PCF Power Plants . . . . . . . . . 90

25 PAH Concentrations Measured in Flue Gas from PCF Plants . . . . . . . . . 91

26 PAH Concentrations Measured in Flue Gas from Coal-Fired

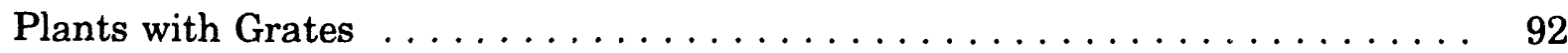




\section{TABLES (Cont.)}

27 PAH Concentrations Measured in Flue Gas from FBC Plants . . . . . . . . 93

$28 \quad$ Organic Stack Emissions Measured from Coal-Fired

Conventional Power Plants ........................ 95

A.1 Calculated Annual Trace Llement Emissions from a New, Modern, 500-MWe Power Plant Firing U.S. Appalachian Bituminous Coal

101

A.1.1 Calculated Annual Trace Element Emissions from a New, Modern, 500-MWe Power Plant Firing U.S. Pennsylvania Bituminous Coal . . . . . .

A.1.2 Calculated Annual Trace Element Emissions from a New, Modern, 500-MWe Power Plant Firing U.S. Eastern Kentucky

Bituminous Coal . . . . . . . . . . . . . . . . . . . . . . .

A.1.3 Calculated Annual Trace Element Emissions from a New, Modern, 500-MWe Power Plant Firing U.S. Ohio Bituminous Coal . . . . . . . . . . . .

A.1.4 Calculated Annual Trace Element Emissions from a New, Modern, 500-MWe Power Plant Firing U.S. Tennessee Bituminous Coal . . . . . . . . .

A.1.5 Calculated Annual Trace Element Emissions from a New, Modern, 500-MWe Power Plant Firing U.S. West Virginia Bituminous Coal . . . . . .

A.1.6 Calculated Annual Trace Element Emissions from a New, Modern, 500-MWe Power Plant Firing U.S. Virginia Bituminous Coal . . . . . . . . . . 107

A.2 Calculated Annual Trace Element Emissions from a New, Modern, 500-MWe Power Plant Firing U.S. Interior Bituminous Coal . . . . . . . . .

A.2.1 Calculated Annual Trace Element Emissions from a New, Modern, 500-MWe Power Plant Firing U.S. Illinois Bituminous Coal . . . . . . . . .

A.2.2 Calculated Annual Trace Element Emissions from a New, Modern, 500-MWe Power Plant Firing U.S. Iowa Bituminous Coal . . . . . . . . . . . .

A.2.3 Calculated Annual Trace Element Emissions from a New, Modern, 500-MWe Power Plant Firing U.S. Missouri Bituminous Coal . . . . . . . . . .

A.2.4 Calculated Annual Trace Element Emissions from a New, Modern. 500-MWe Power Plant Firing U.S. Oklahoma Bituminous Coal . . . . . . . . .

A.2.5 Calculated Annual Trace Element Emissions from a New, Modern, 500-MWe Power Plant Firing U.S. Indiana Bituminous Coal . . . . . . . . .

A.2.6 Calculated Annual Trace Element Emissions from a New, Modern, 500-MWe Power Plant Firing U.S. Arkansas Bituminous Coal 


\section{TABLES (Cont.)}

A.3 Calculated Annual Trace Element Emissions from a New, Modern, 500-MWe Power Plant Firing U.S. Rocky Mountain Bituminous Coal . . . . .

A.3.1 Calculated Annual Trace Element Emissions from a New, Modern, 500-MWe Power Plant Firing U.S. North Park, Colorado, Bituminous Coal . . . . . . . . . . . . . . . . . . . . .

A.3.2 Calculated Annual Trace Element Emissions from a New, Modern, 500-MWe Power Plant Firing U.S. Hanna, Wyoming,

Bituminous Coal . . . . . . . . . . . . . . . . . . . .

A.3.3 Calculated Annual Trace Element Emissions from a New, Modern, 500-MWe Power Plant Firing U.S. Black Mesa, Arizona,

Bituminous Coal . . . . . . . . . . . . . . . . . . . . .

A.3.4 Calculated Annual Trace Element Emissions from a New, Modern, 500-MWe Power Plant Firing U.S. Uinta, Utah, Bituminous Coal . . . . . . .

A.4 Calculated Annual Trace Dlement Emissions from a New, Modern, 500-MWe Power Plant Firing U.S. Northern Plains

Lignite/Subbituminous Coal $\ldots \ldots \ldots \ldots \ldots \ldots \ldots \ldots$

A.4.1 Calculated Annual Trace Element Emissions from a New, Modern, 500-MWe Power Plant Firing U.S. North Dakota Lignite . . . . . . . . . . . .

A.4.2 Projected Quantity of Trace Elements Likely to Be Emitted Annually from a New, Modern, 500-MWe Power Plant Firing U.S. Wyoming

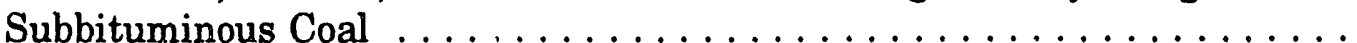

A.4.3 Calculated Annual Trace Element Emissions from a New, Modern, 500-MWe Power Plant Firing U.S. Montana Subbituminous Coal . . . . . . .

A.5 Calculated Annual Trace Element Emissionsfrom a New, Modern, 500-MWe Power Plant Firing U.S. Gulf Lignite . . . . . . . . . . . . . . .

A.5.1 Calculated Annual Trace Element Emissions from a New, Modern, 500-MWe Power Plant Firing U.S. Alabama Lignite . . . . . . . . . . . . .

A.6 Calculated Annual Trace Element Emissions from a New, Modern, 500-MWe Power Plant Firing U.S. Alaska Subbituminous Coal . . . . . . .

A.7 Calculated Annual Trace Element Emissions from a New, Modern, 500-MWe Power Plant Firing U.S. Pennsylvania Anthracite . . . . . . . . . . . 


\section{FIGURES}

1 Typical Concentrations of the Vaporous Elements - $\mathrm{Cl}, \mathrm{F}$, and $\mathrm{Hg}-$ by

U.S. Region and Coal Rank . . . . . . . . . . . . . . . . . . . 69

2 Typical Concentrations of Elements that Concentrate in Fly Ash - Sb, $\mathrm{As}, \mathrm{Cd}, \mathrm{Cr}, \mathrm{Pb}, \mathrm{Ni}$, and $\mathrm{Se}$ - by U.S. Region and Coal Rank . . . . . . . . . $\mathrm{\gamma}^{0}$

3 Typical Concentrations of $\mathrm{Hg}$ by Coal Rank for Each U.S. State where Sufficient Data Exist 


\section{NOTATION}

\section{ACRONYMS, INITLALISMS, AND ABBREVIATIONS}

$\begin{array}{ll}\text { AFBC } & \text { atmospheric fluidized-bed combustor/combustion } \\ \text { an } & \text { anthracite } \\ \text { App } & \text { Appalachian } \\ \text { bit } & \text { bituminous } \\ \text { CAA. } & \text { Clean Air Act } \\ \text { CAAA } & \text { Clean Air Act Amendments } \\ \text { CG } & \text { carcinogen } \\ \text { CSTM } & \text { Coal Supply and Transportation Model } \\ \text { DOE } & \text { U.S. Department of Energy } \\ \text { EC } & \text { European Community } \\ \text { EEC } & \text { European Economic Community } \\ \text { EPA } & \text { U.S. Environmental Protection Agency } \\ \text { EPRI } & \text { Electric Power Research Institute } \\ \text { ESP } & \text { electrostatic precipitator } \\ \text { FBC } & \text { fluidized-bed coinbustor/combustion } \\ \text { FDA } & \text { Food and Drug Administration } \\ \text { FGD } & \text { flue-gas desulfurization } \\ \text { HAP } & \text { hazardous air pollutant } \\ \text { Int } & \text { Interior } \\ \text { lig } & \text { lignite } \\ \text { max. } & \text { maximum } \\ \text { min. } & \text { minimum } \\ \text { NA } & \text { not available } \\ \text { NC } & \text { noncarcinogen } \\ \text { NESHAP } & \text { National Emission Standards for Hazardous Air Pollutants } \\ \text { NPl } & \text { Northern Plains } \\ \text { OEA } & \text { Office of Environmental Analysis } \\ \text { OSHA } & \text { Occupational Safety and Health Administration } \\ \text { PAH } & \text { polycyclic aromatic hydrocarbon } \\ \text { PCF } & \text { pulverized-coal-fired } \\ \text { Penn. } & \text { Pennsylvania } \\ \text { PETC } & \text { Pittsburgh Energy Technology Center } \\ \text { PFBC } & \text { pressurized fluidized-bed combustor/combustion } \\ \text { POM } & \text { polycyclic organic matter } \\ \text { RMitn } & \text { Rocky Mountain } \\ \text { sub } & \text { subbituminous } \\ \text { U.K. } & \text { United Kingdom } \\ \text { USGS } & \text { U.S. Geological Survey } \\ \end{array}$

\section{Chemical Symbols}

$\begin{array}{ll}\text { Al } & \text { aluminum } \\ \text { As } & \text { arsenic }\end{array}$




\section{Chemical Symbols (Cont.)}

\begin{tabular}{|c|c|}
\hline B & boron \\
\hline $\mathbf{B a}$ & barium \\
\hline $\mathrm{Be}$ & beryllium \\
\hline $\mathrm{Br}$ & bromine \\
\hline $\mathrm{Ca}$ & calcium \\
\hline $\mathrm{Cd}$ & cadmium \\
\hline $\mathrm{Cl}$ & chlorine \\
\hline Co & cobalt \\
\hline $\mathrm{Cr}$ & chromium \\
\hline $\mathrm{Cu}$ & copper \\
\hline $\mathbf{F}$ & fluorine \\
\hline $\mathrm{Fe}$ & iron \\
\hline $\mathrm{Ge}$ & germanium \\
\hline HF & hydrofluoric acid; hydrogen fluoride \\
\hline $\mathrm{H}_{2} \mathrm{~S}$ & hydrogen sulfide \\
\hline $\mathrm{HCl}$ & hydrochloric acid; hydrogen chloride \\
\hline $\mathrm{Hg}$ & mercury \\
\hline $\mathrm{K}$ & potassium \\
\hline $\mathrm{Li}$ & lithium \\
\hline Mg & magnesium \\
\hline $\mathrm{Mn}$ & manganese \\
\hline Mo & molybdenur \\
\hline $\mathbf{N}$ & nitrogen \\
\hline $\mathrm{Na}$ & sodium \\
\hline $\mathrm{Ni}$ & nickel \\
\hline $\mathrm{NO}_{\mathbf{x}}$ & nitrogen oxides \\
\hline$P^{x}$ & phosphorus \\
\hline $\mathrm{Pb}$ & lead \\
\hline $\mathbf{R a}$ & radium \\
\hline $\mathrm{Rn}$ & radon \\
\hline $\mathbf{S}$ & sulfur \\
\hline $\mathrm{Sb}$ & antimony \\
\hline Se & selenium \\
\hline $\mathrm{Si}$ & silicon \\
\hline $\mathrm{Sn}$ & $\operatorname{tin}$ \\
\hline $\mathrm{SO}_{2}$ & sulfur dioxide \\
\hline $\mathrm{Sr}$ & strontium \\
\hline $\mathrm{Th}$ & thorium \\
\hline $\mathrm{Ti}$ & titanium \\
\hline $\mathrm{Tl}$ & thallium \\
\hline $\mathrm{U}$ & uranium \\
\hline V & vanadium \\
\hline $\mathrm{Zn}$ & zinc \\
\hline
\end{tabular}




\section{Units of Measure}

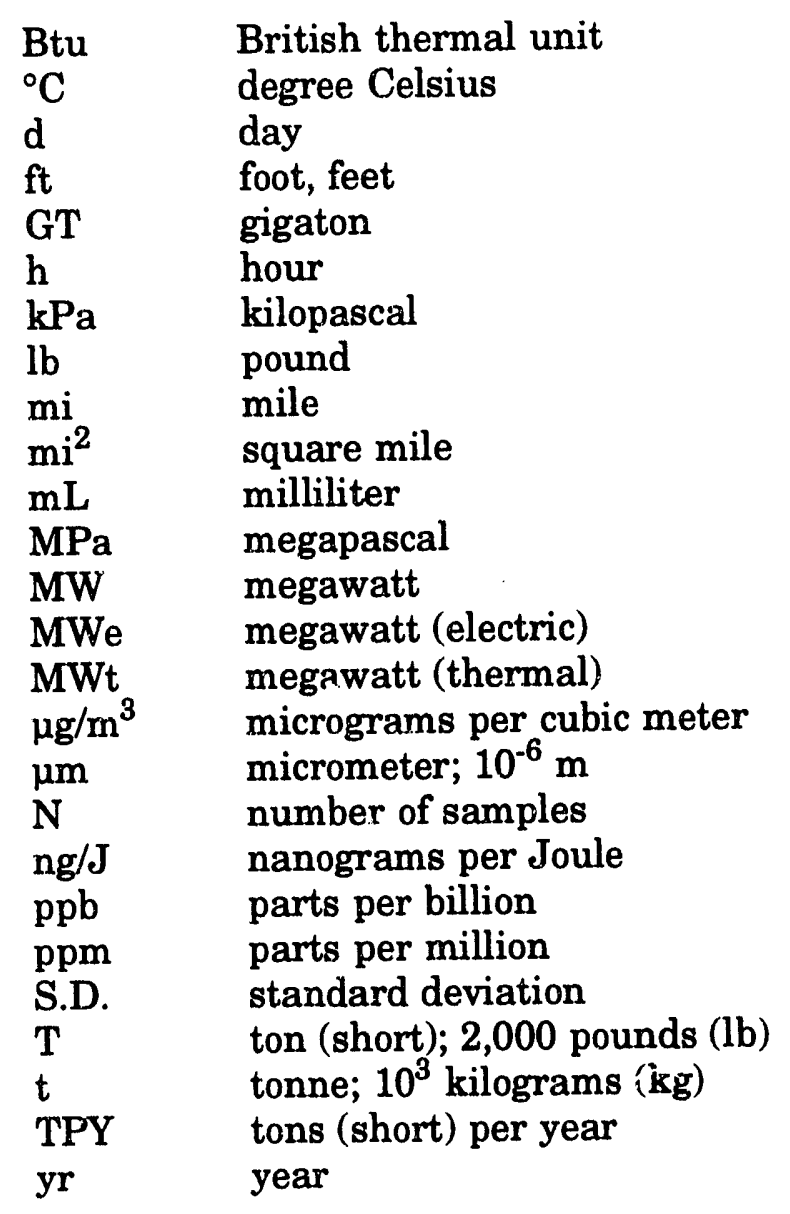




\title{
AIR TOXIC EMISSIONS FROM THE COMBUSTION OF COAL: IDENTIFYING AND QUANTIFYING HAZARDOUS AIR POLLUTANTS FROM U.S. COALS
}

by

C.B. Szpunar

\begin{abstract}
This report addresses the key air toxic emissions likely to emanate from continued and expanded use of domestic coal. It identifies and quantifies those trace elements specified in the U.S. 1990 Clean Air Act Amendments, by tabulating selected characterization data on various source coals by region, state, and rank. On the basis of measurements by various researchers, this report also identifies those organic compounds likely to be derived from the coal combustion process (although their formation is highly dependent on specific boiler config ations and operating conditions).
\end{abstract}

\section{INTRODUCTION}

\subsection{STUDY RATIONALE}

Significant changes are expected in the regulation of hazardous air pollutants (HAPs), changes caused primarily by Title III of the 1990 Clean Air Act Amendments (CAAA) and secondarily by Section 112(b) of the Clean Air Act (CAA), as amended in 1990 (U.S. Congress 1990). The CAA requires the regulation of 189 HAPs (later changed to 188 with the exclusion of hydrogen sulfide, $\mathrm{H}_{2} \mathrm{~S}$ ), although not all are considered significant for the generation of electricity.

The U.S. Environmental Protection Agency (EPA) is required by the 1990 CAAA to promulgate rules for all "major" sources of any of these HAPs. According tu the Hazardous Air Pollutants section of the new Title III, any stationary source emitting 10 tons* per year (TPY) of one HAP or 25 TPY of a combination of HAPs will be considered and designated a major source. In contrast to the original National Emission Standards for Hazardous Air Pollutants (NESHAP), which were designed to protect public health to "an ample margin of safety," the new Title III, in its first phase, will regulate by industrial category those sources emitting HAPs in excess of the 10/25-TPY threshold levels, regardless of health risks.

\footnotetext{
"The word "ton," abbreviated "T," means a short ton or 2,000 lb. The short ton is used as the unit of measure (rather than the metric ton $=10^{3} \mathrm{~kg}$ ) unless otherwise noted.
} 
The trace elements normally associated with the mineral matter in coal and the various compounds formed during coal combustion have the potential to produce hazardous air toxic emissions from coal-fired elect i. utilities. Under Title III, the EPA is required to perform certain studies, prior to any regulation of electric utilities. These studies are the following:

1. A study of the hazards to public health reasonably anticipated to occur as a result of emissions of pollutants by electric utility steam generating units. This study also will describe the development of alternative control strategies for emissions that may warrant regulation and provide the data for the determination to be made as to whether regulation of electric utility steam generating units is appropriate and necessary (due November 1993).

2. A study of mercury $(\mathrm{Hg})$ emissions from electric utility steam generating units, municipal waste combustion units, and other sources, considering the rate and mass of such emissions, the health and environmental effects of such ernissions, the technologies that are available to control such emissions, and the costs of such technologies (due November 1994).

3. A study to determine the threshold level of $\mathrm{Hg}$ exposure below which adverse human health effects are not expected to occur (due November 1993).

Despite the statutory deadline, the EPA has decided to combine the first two studies into a single study not expected to be final before November 1995. The U.S. Department of Energy (DOE) and the Electric Power Research Institute (EPRI) are actively involved in aspects of these studies.

In July 1992, the EPA fublished its initial list (previously published in draft) of categories of major and area sources under Section 112(c)(1) of the CAA, as amended in 1990 (EPA 1992). However, the EPA declined to list radionuclide emitters and electric utility steam generating units above $25 \mathrm{MW}$ at this time. The EPA is expected to revisit these source categories when sufficient additional information becomes available.

Some experts believe that, despite its great costs, the air toxics title (III) could also provide great benefits to the U.S. public. However, many experts believe the potential benefits are not great enough to justify the costs. Therefore, potential responses to HAP legislation need to identify both the energy-related industries affected and the options available for compliance.

Besides the EPA mandate to promulgate rules about health for major sources of the listed HAFs, the DOE maintains a vested interest in addressing policy questions involving the domestic energy sector. Because electric utility generation, coal mining, and steel producing are critical to this country's economic well-being and remain under the DOE's purview, the DOE Office of Environmental Analysis (OEA) is obligated to address policy 
questions along these lines. In addition, the OEA remains concerned about balancing the costs to the producers and users of energy with the benefits of environmental protection to workers and the general populace.

\subsection{PROJECT SCOPE}

Considerable actual HAP emissions data already exist for many of the stationary sources that will be designated as major sources under Title III. In these cases, the EP. will be able to use sound scientific data to prepare regulations. In contrast, a limited $\mathrm{d} \varepsilon$, base exists for coal-fired utility boilers. Much of the technical literature concerning toxic emissions from coal combustors consists of calculated values based on test burns under controlled conditions or incomplete material balance studies that relate the emissions of trace metals to the inorganic composition of the input coal. Also, there is a high degree of uncertainty concerning much of the data on some of the more volatile components conts... in the generated flue gas. For example, results from a literature survey indicateu that wet scrubbers may remove anywhere from 20 to $80 \%$ of the mercury from utility boiler flue gas (Brown et al. 1991).

This study was formulated to address the key air toxic emiss_ons likely to emanate from continued and expanded use of dcmestic coal, by identifying and quantifying the trace elements (primarily metals and other entities) in U.S. coals and by tabulating selected characterization data on various source coals.

By addressing the CAAA-listed trace elements in U.S. coals, this study may suggest a better way to classify domestic utility coals with respect to their air toxic emissions precursors; such a classification would enhance the mere statement of a combustion feed coal's sulfur dioxide $\left(\mathrm{SO}_{2}\right)$ emission level expected from its sulfur content.

It is even more difficult to identify and quantify potential organic compounds likely to be emitted during the coal combustion process; it is impossible to do so on the basis of source coal composition alone because specific organic emissions from combustion depend significantly on boiler configuration or design and actual operating conditions. Hence, organics are identified and quantified in this study by inference from the reported data of some actual research measurements; this compilation is offered as an indication of likely organic compounds that should be monitored.

Specifically, this study dors the following:

1. Explores and examines the literature regarding the presence, magnitude, and behavior of the precursor trace elements of potential air toxic emissions from the combustion of coals of different types; compiles and summarizes those data by coal region, by coal-producing state, and by coal rank; and suggests a systematic way of classifying those potentially offending trace elements present in coal. 
2. Identifies how the trace elements partition themselves upon coal combustion, leading to atmospheric emissions, and discusses why standard emission factors are difficult or even impossible to derive.

3. Indicates the magnitude of the anticipated emissions, through projection and calculation of the expected volumes of trace element emissions on the basis of a uev, modern, 500-MW, coal-fired plant, relative to the CAAA 10/25-TPY stipulation. (This study does not project and calculate expected volumes of real-world trace element emissions of existing coalfired plants, although such work may merit a separate study. This study does not compile studies in which trace element measurements have actually been assembled.)

4. Characterizes the organic compounds derived from coal that may be emitted upon combustion and that have been identified as air toxics.

5. Indicates the identity and quantity of these likely organic emissions by plant type. 


\section{IDENTIFICATION OF HAZARDOUS AIR POLLUTANTS FROM COAL}

Section 112(b) of the Clean Air Act, as amended in 1990, lists 188 HAPs, including compounds of antimony ( $\mathrm{Sb}$ ), arsenic, (As), beryllium (Be), ccidmium (Cd), chromium (Cr), cobalt $(\mathrm{Co})$, lead $(\mathrm{Pb})$, manganese $(\mathrm{Mn}), \mathrm{Hg}$, nickel $(\mathrm{Ni})$, and selenium (Se). Also listed are chlorine (Cl) and hydrochloric acid (HCl Iuorine (F) as hydrofluoric acid (HF), phosphorus $(\mathrm{P})$, and the radionuclides (including rauivn [Rn], thorium [Th], and uranium [U]).

The CAA also lists many specific organic compounds including benzene, carbon tetrachloride, chloroform, dibenzofuran, formaldehyde, hexachlorobenzene, phenol, dioxin, toluene, and trichloroethylene and the generic class of polycyclic organic matter (POM) (defined as organic compounds with more than one benzene ring and a builing point of $100^{\circ} \mathrm{C}$ or higher).

In addition, the CAA specifies asbestos, coke oven emissions, and fine mineral fibers ${ }^{*}$ as HAPs; but these air toxics are not discussed here becauce they are beyond the scops of this report.

\subsection{TRACE ELEMENTS}

All but 16 of the 92 naturally occurring elements have been detected in coal, mostly as trace elements, at levels below $0.1 \%$ (1,000 parts per million [ppm]) (Akers et al. 1989). The relative importance of trace elements in coal relative to coal usage is nct easily established and depends on several variables, including concentration in coal (Swaine 1990).

Swaine suggests that most of the reported possible adverse effects of trace elements in coal are unlikely to occur with modern coal use. Swaine maintains that the statement of McCarroll (1980) still holds true: "... with presently available control technology, no detectable adverse health effects will be observed associated with increased coal combustion."

Nevertheless, some researchers consider various trace elements to be of environmental concern in a number of ways. Several trace element and environmental schemes are categorized below.

\subsubsection{Hazardous Air Pollutants Identified by U.S. Government Agencies}

Those elements specifically identified and listed as HAPs in the CAA are $\mathrm{Sb}, \mathrm{As}, \mathrm{Be}$, $\mathrm{Cd}, \mathrm{Cl}, \mathrm{Cr}, \mathrm{Co}, \mathrm{F}, \mathrm{Pb}, \mathrm{Mn}, \mathrm{Hg}, \mathrm{Ni}, \mathrm{P}, \mathrm{Se}, \mathrm{Rn}, \mathrm{Th}$, and $\mathrm{U}$. Why these elements have been identified as HAPs and why they are important will become clear later in this report. Here

\footnotetext{
Emissions from facilities manufacturing or processing glass, rock, or slag fibers of an average diameter of $1 \mu \mathrm{m}$ or less.
} 
we can consider the various categories that these elements have been associated with recently in various health and risk contexts.

For example, in its December 1990 draft Source Category List (EPA 1990a), the EPA identified $\mathrm{As}, \mathrm{Be}, \mathrm{Cd}, \mathrm{Cr}, \mathrm{Pb}, \mathrm{Mn}, \mathrm{Hg}, \mathrm{Ni}, \mathrm{P}$, and $\mathrm{Se}$ as those elements requiring standards and monitoring by energy-related industry source category (Hootman and Vernet 1991) (Table 1). The EPA (1991) identified $\mathrm{As}, \mathrm{Be}, \mathrm{Cd}, \mathrm{Cr}$, and $\mathrm{Hg}$ as having high risk for adverse public health effects. In September 1990, the EPA (1990b) cited these elements (air toxics) as contributing significantly to cancer risk from outdoor exposure: $\mathrm{As}, \mathrm{Cd}, \mathrm{Cr}, \mathrm{Rn}, \mathrm{Th}$, and U. And in January 1992, the DOE (1992) Pittsburgh Energy Technology Center (PETC) identified those elements that will be measured and assessed in an upcoming research project as toxic emissions from coal-fired plants: $\mathrm{Sb}, \mathrm{As}, \mathrm{Be}, \mathrm{Cd}, \mathrm{Cl}, \mathrm{Cr}, \mathrm{Co}, \mathrm{F}, \mathrm{Pb}, \mathrm{Mn}, \mathrm{Hg}, \mathrm{Ni}, \mathrm{Se}$, $\mathrm{Rn}$, Th, and $\mathrm{U}$. (Only $\mathrm{P}$ is not included relative to the CAA list.)

\subsubsection{Hazardous Air Pollutants Identified b- Nongovernment and Industry Researchers}

The EPRI (Boutacoff 1991) has cited various trace elements as having been detected in fossil fuel power plant flue gas ( $\mathrm{Sb}, \mathrm{As}, \mathrm{Be}, \mathrm{Cd}, \mathrm{Cl}, \mathrm{Cr}, \mathrm{Co}, \mathrm{F}, \mathrm{Pb}, \mathrm{Mn}, \mathrm{Hg}, \mathrm{Ni}, \mathrm{P}$, and $\mathrm{Se}$ ) (Table 2) and as hazardous air pollutants in general (As, barium [Ba], $\mathrm{Be}, \mathrm{Cd}, \mathrm{Cl}, \mathrm{Cr}, \mathrm{Co}$, copper [Cu], F, Pb, Mn, Hg, molybdenum [Mo], Ni, P, Se, and vanadium [V]) (Mann et al. 1991).

The U.S. National Research Council has categorized the trace and minor elements of environmental concern with respect to coal utilization (Akers et al. 1989). These elements are the following:

1. Of greatest concern - As, B (boron), Cd, $\mathrm{Hg}, \mathrm{Mo}, \mathrm{N}$ (nitrogen), $\mathrm{Pb}$, $\mathrm{S}$ (sulfur), and Se;

2. Of moderate concern - $\mathrm{Cr}, \mathrm{Cu}, \mathrm{F}, \mathrm{Ni}, \mathrm{V}$, and $\mathrm{Zn}$ (zinc);

3. Of minor concern - $\mathrm{Ba}, \mathrm{Br}$ (bromine), $\mathrm{Cl}, \mathrm{Co}, \mathrm{Ge}$ (germanium), $\mathrm{Li}$ (lithium), Mn, $\mathrm{Na}$ (sodium), and $\mathrm{Sr}$ (strontium); and

4. Of a radioactive nature $-\mathrm{Rn}$, $\mathrm{Th}$, and $\mathrm{U}$.

Swaine (1982) has categorized trace elements in two ways - those of prime environmental interest and those that could be of environmental interest:

1. Of prime environmental interest - $\mathrm{As}, \mathrm{Cd}, \mathrm{Cr}, \mathrm{F}, \mathrm{Hg}, \mathrm{Ni}, \mathrm{Pb}$, and $\mathrm{Se}$;

2. Could be of environmental interest - B, Be, Cl, $\mathrm{Co}, \mathrm{Cu}, \mathrm{Mn}, \mathrm{Mo}, \mathrm{Sb}$, $\mathrm{Sn}$ (tin), Th, Tl (thallium), U, V, and $\mathrm{Zn}$. 
TABLE 1 Trace Elements: EPA- and DOE-Identified Hazardous Air Pollutants

\begin{tabular}{|c|c|c|c|c|}
\hline $\begin{array}{c}1990 \\
\text { CAA } \\
\text { HAPs }^{2}\end{array}$ & $\begin{array}{l}\text { EPA Draft } \\
\text { Source } \\
\text { Category } \\
\text { Pollutants }^{b}\end{array}$ & $\begin{array}{c}\text { EPA High-Risk } \\
\text { Pollutants for Adverse } \\
\text { Public Health Effects }\end{array}$ & $\begin{array}{l}\text { EPA Contributors } \\
\text { to Cancer Risk from } \\
\text { Outdoor Exposure }\end{array}$ & $\begin{array}{l}\text { DOE/PETC } \text { Toxic }^{\text {e }} \\
\text { Emissions to Be } \\
\text { Measured from } \\
\text { Coal-Fired Plants }\end{array}$ \\
\hline $\mathrm{Sb}$ & & & & $\mathrm{Sb}$ \\
\hline As & As & As - CG & As & $\begin{array}{l}\mathrm{As} \\
\mathrm{Ba}\end{array}$ \\
\hline $\mathrm{Be}$ & $\mathrm{Be}$ & $\mathrm{Be}-\mathrm{CG}$ & & $\begin{array}{l}\mathrm{Be} \\
\mathrm{B}\end{array}$ \\
\hline $\begin{array}{l}\mathrm{Cd} \\
\mathrm{Cl} / \mathrm{HCl}\end{array}$ & $\mathrm{Cd}$ & $\mathrm{Cd}-\mathrm{CG}$ & $\mathrm{Cd}$ & $\begin{array}{l}\mathrm{Cd} \\
\mathrm{HCl}\end{array}$ \\
\hline $\begin{array}{l}\mathrm{Cr} \\
\mathrm{Co}\end{array}$ & $\mathrm{Cr}$ & $\mathrm{Cr}-\mathrm{CG}$ & $\mathrm{Cr}$ & $\begin{array}{l}\mathrm{Cr} \\
\mathrm{Co} \\
\mathrm{Cu}\end{array}$ \\
\hline $\mathbf{H F}$ & & & & HF \\
\hline $\mathrm{Pb}$ & $\mathrm{Pb}$ & & & $\mathrm{Pb}$ \\
\hline $\mathrm{Mn}$ & $\mathrm{Mn}$ & & & $\mathrm{Mn}$ \\
\hline $\mathrm{Hg}$ & $\mathrm{Hg}$ & $\mathrm{Hg}-\mathrm{NC}^{\mathrm{h}}$ & & $\begin{array}{l}\mathrm{Hg} \\
\mathrm{Mo}\end{array}$ \\
\hline $\mathrm{Ni}$ & $\mathrm{Ni}$ & & & $\mathrm{Ni}$ \\
\hline $\mathbf{P}$ & $\mathbf{P}$ & & & $\mathbf{P}$ \\
\hline $\mathrm{Se}$ & $\mathrm{Se}$ & & & $\begin{array}{l}\mathrm{Se} \\
\mathrm{V}\end{array}$ \\
\hline$R \mathbf{n}$ & & & $\mathbf{R n}$ & Rn \\
\hline $\mathrm{Th}$ & & & Th & Th \\
\hline $\mathbf{U}$ & & & $\mathbf{U}$ & $\mathrm{U}$ \\
\hline
\end{tabular}

a U.S. Congress (1990).

b $\operatorname{EPA}(1990 \mathrm{a})$.

c EPA (1991).

d EPA (1990b).

e PETC $=$ Pittsburgh Energy Technology Center.

f DOE (1992).

g $\mathrm{CG}=$ carcinogen.

h $\mathrm{NC}=$ noncarcinogen. 
TABLE 2 Trace Elements of Environmental Interest

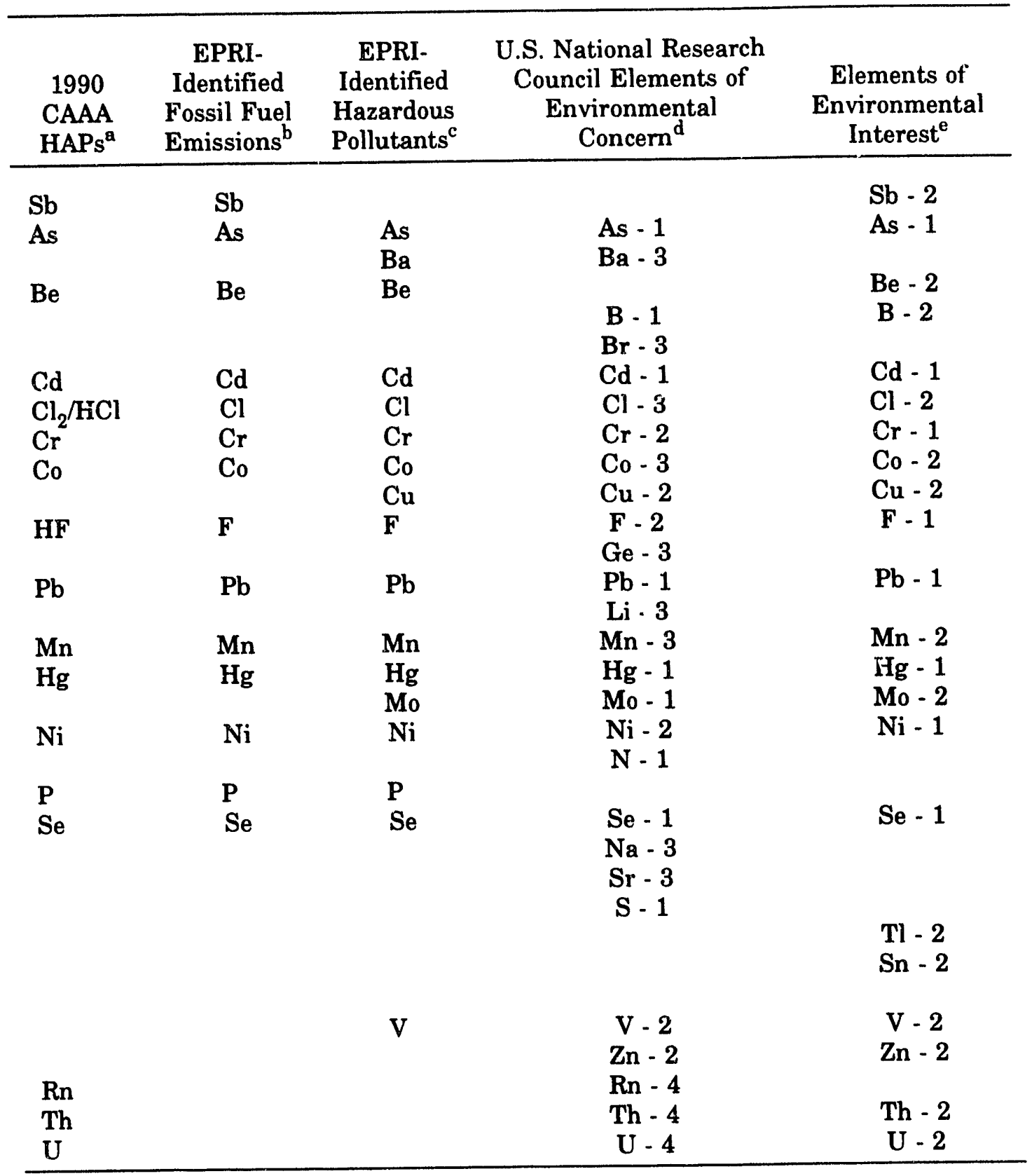

a U.S Congress (1990).

b Boutacoff (1991).

c Mann et al. (1991).

d Akers et al. (1989) lists these trace elements under the four categories of the U.S. National Research Council: 1. Of greatest concern. 2. Of moderate concern. 3. Of minor concern. 4. Of a radioactive nature.

e Swaine (1982) lists these trace elements under two categories: 1. Of prime environmental interest. 2. Could be of environmental interest. 


\subsection{ORGANIC COMPOUNDS}

The 1990 CAAA listing contains 170 organic compounds plus a generic class of POM. To some extent, Table 3 narrows that listing by identifying 47 specific organic compounds cited by the EPA, the DOE, and the EPRI as air toxic emissions related to and derived from coal combustion. 


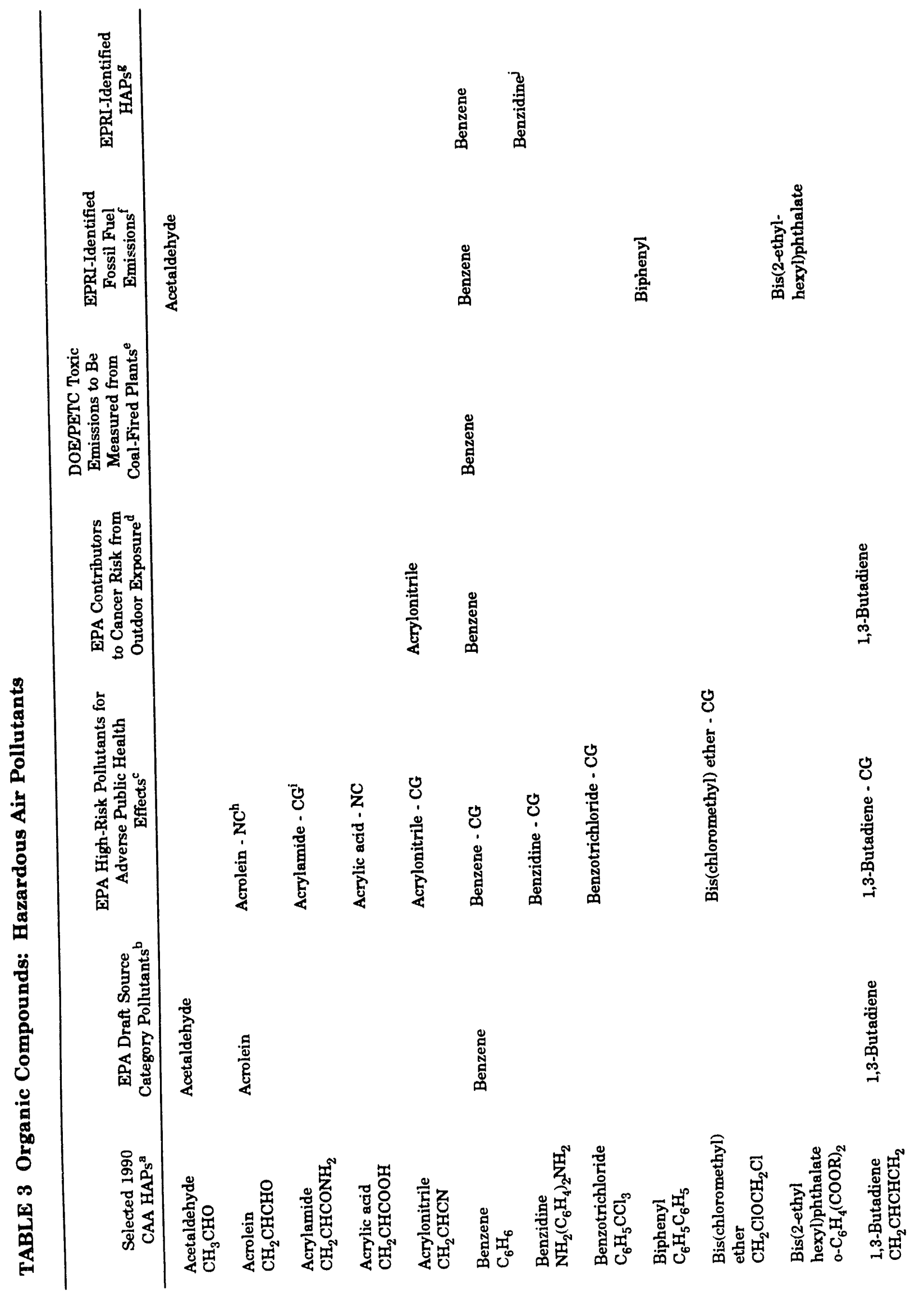




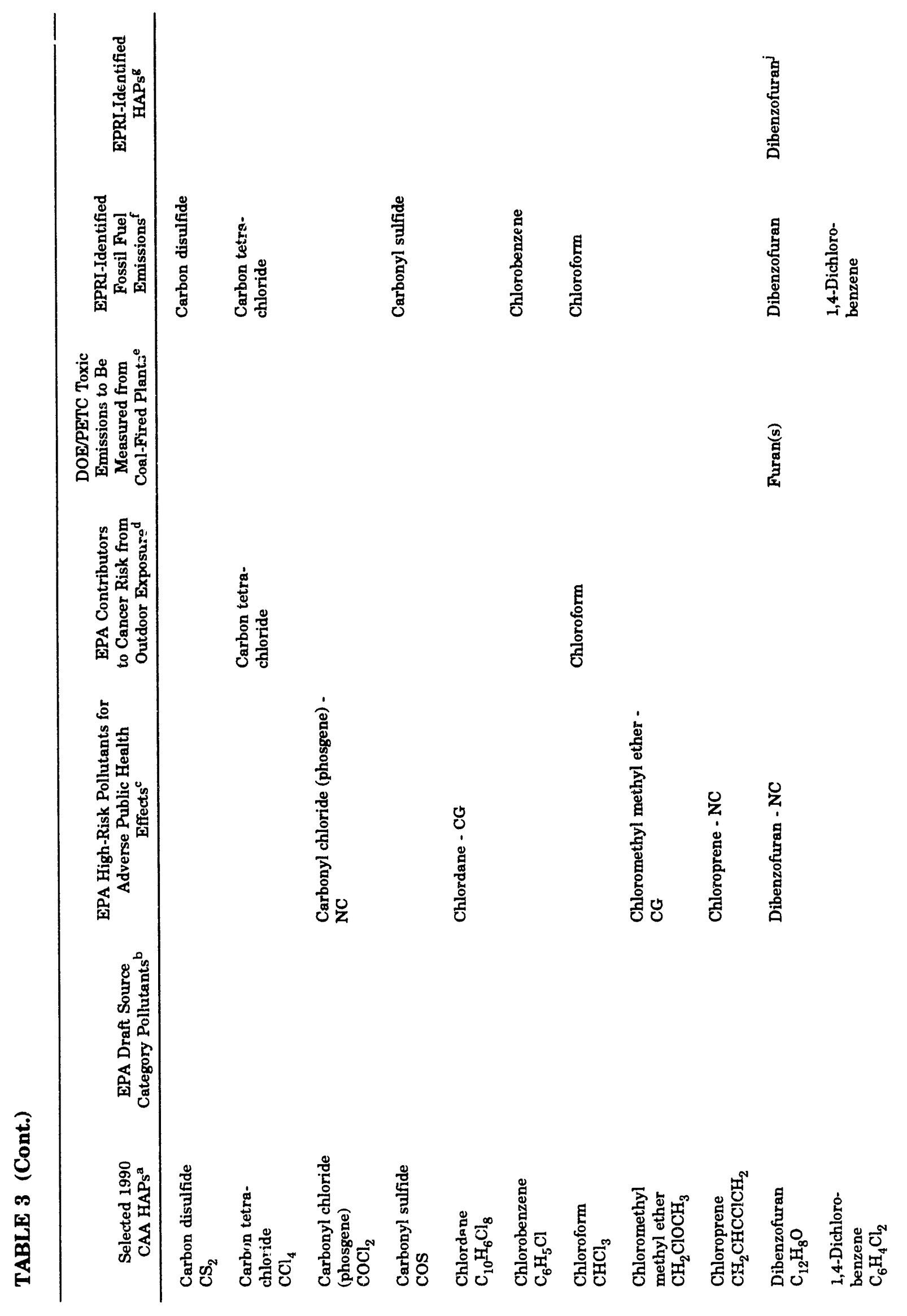




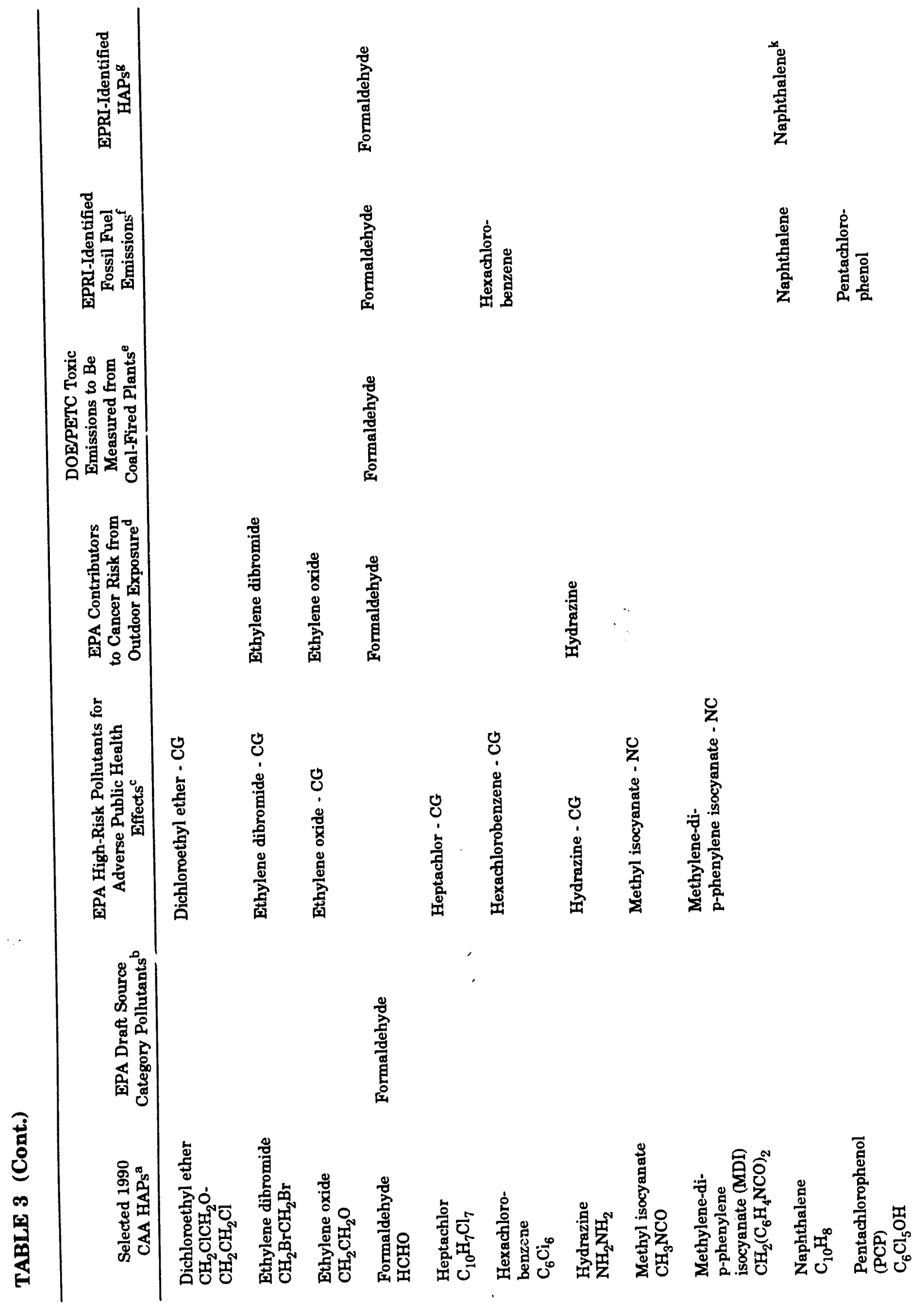




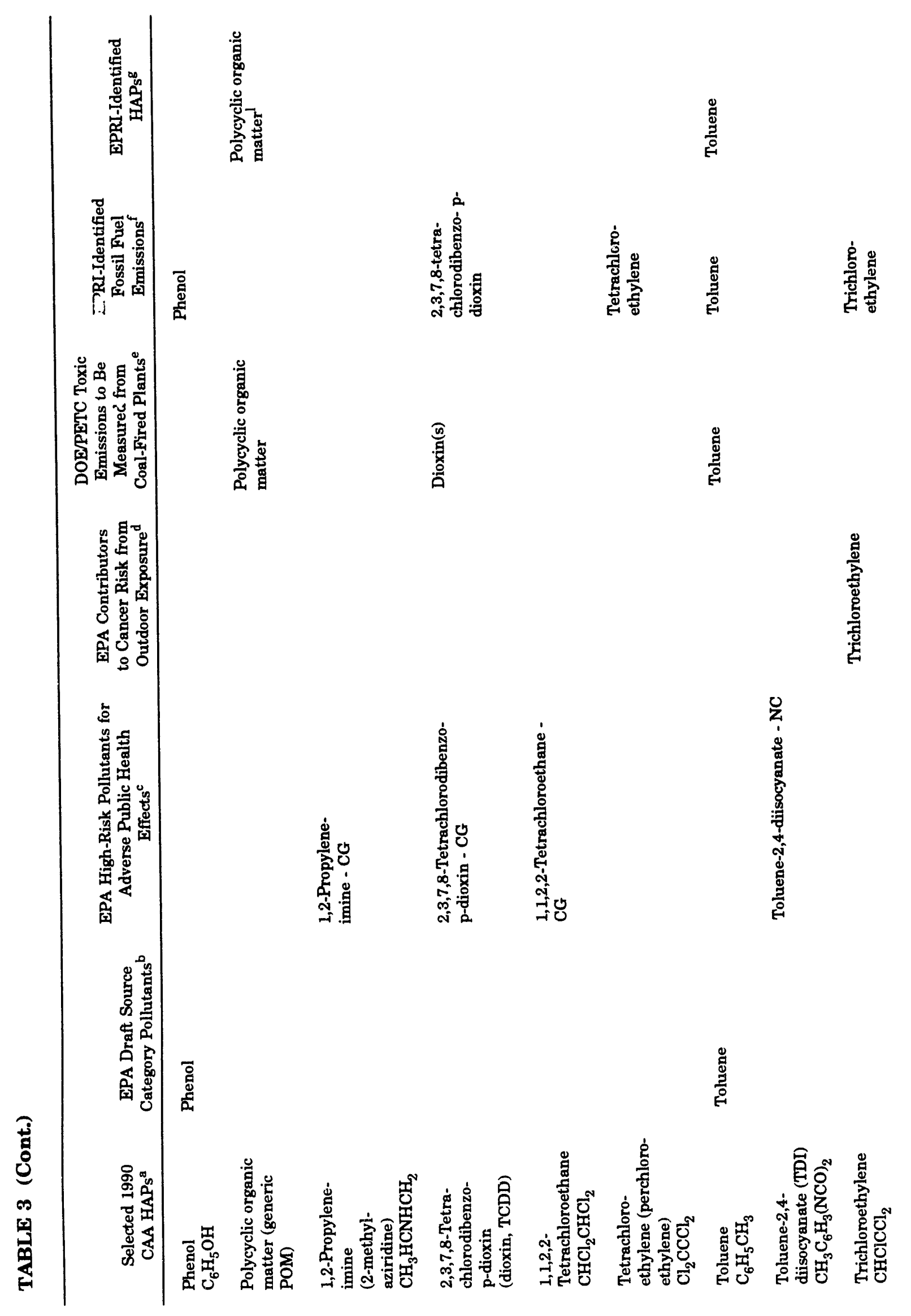




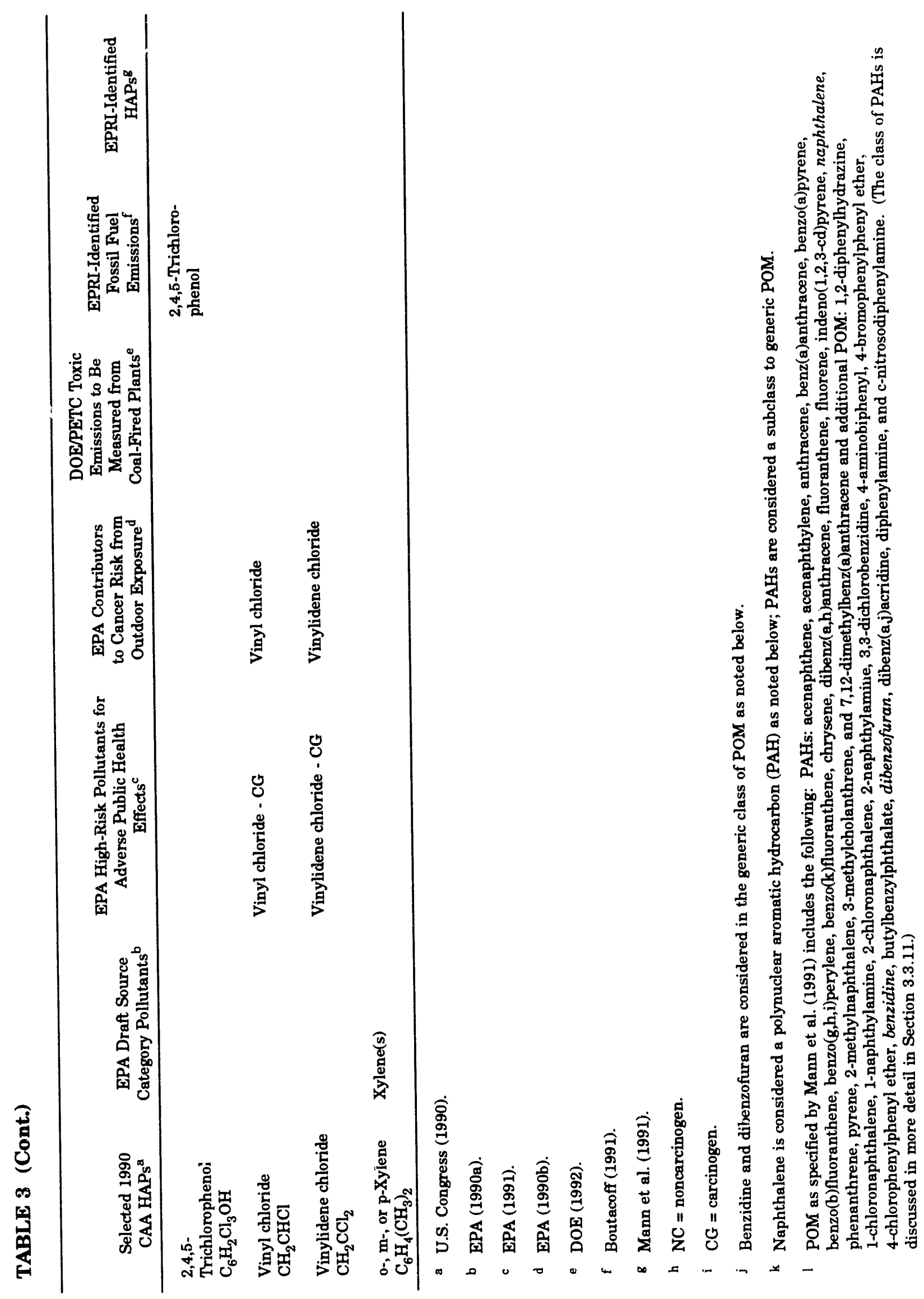




\section{DESCRIPTION OF COAL COMPONENTS AND COMPOUNDS DERIVED FROM COAL CONTRIBUTING TO HAZARDOUS AIR POLLUTANTS}

\subsection{MINERALS IN COAL}

Many distinct types of rocks and minerals have been closely associated with coals and coaly deposits. In spite of some variations from locality to locality and even within individual seams, certain classes of major minerals are present in nearly all coals. These minerals are, in decreasing abundance, the aluminosilicates or clay minerals, sulfides, sulfates, carbonates, and silica (Wewerka et al. 1976).

The principal clay minerals are kaolinite, illite, and mixed-layer illite/ montmorillonite. Most coal-associated mineral matter is usually composed of these clay mineral types - from 52\% (Illinois Basin coals) to more than 90\% (Rao and Gluskoter 1973; O'Gorman and Walker 1972, 1971; and Thiessen et al. 1936).

The main sulfide and sulfate minerals in coals are pyrite, its dimurph, marcasite, and gypsum. These minerals constitute about $25 \%$ of the mineral matter in Illinois coals (Rao and Gluskoter 1973). For U.S. coals, in general, pyrite and marcasite range from essentially zero to as high as $40 \%$ of the total inorganic matter (O'Gorman and Walker 1972). Gypsum may represent as much as $60 \%$ of the minerals in some coals, although such high percentages are unusual (O'Gorman and Walker 1972).

Carbonate minerals are found in coals in a wide range of compositions, usually as mixtures of calcite, dolomite, and siderite. These carbonates average about $9 \%$ of the mineral matter in Illinois coals (Rao and Gluskoter 1973) and do not often exceed $10 \%$ of the total inorganic material in most other U.S. coals (O'Gorman and Walker 1972, 1971).

Quartz (silica) is very seldom found in coals in large amounts. Generally, about 20\% of the mineral constituents is the maximum (O'Gorman and Walker 1972). Rao and Gluskoter (1973) report that quartz represents about $15 \%$ of the minerals in Illinois coals.

In addition to these major minerals, various other less abundant minerals have been identified in coals. Table 4 lists these minerals in decreasing abundance.

Of the many trace or minor elements in coals, most are distributed among or within the major-mineral constituents; the few exceptions are almost exclusively associated with the organic coal components (Gluskoter 1975; Ruch et al. 1974; and Zubovic 1966).

The actual associations or relationships among the various trace elements and coal

minerals have been explored in only a few instances. A positive correlation has been found between some of the trace elements in the coals and specific mineral types - $\mathrm{As}, \mathrm{Be}$, and Sb in pyrite; $\mathrm{Cd}$ and $\mathrm{Hg}$ in sphalerite; $\mathrm{Cd}, \mathrm{Mn}$, and Se in calcite; $\mathrm{Cr}, \mathrm{Mn}, \mathrm{Cd}$, and $\mathrm{Se}$ in quartz; 
TABLE 4 Minerals in Coal

\begin{tabular}{|c|c|c|}
\hline \multirow[b]{2}{*}{ Minerals } & \multicolumn{2}{|c|}{ Abundance in Coal ${ }^{\mathrm{a}}$} \\
\hline & Major & Minor \\
\hline $\begin{array}{l}\text { Alumino- } \\
\text { silicates }\end{array}$ & $\begin{array}{l}\text { Illites } \\
\text { Kaolinite } \\
\text { Illite/montmorillonite }\end{array}$ & - \\
\hline Sulfides & $\begin{array}{l}\text { Pyrite } \\
\text { Marcasite }\end{array}$ & $\begin{array}{l}\text { Sphalerite } \\
\text { Galena }\end{array}$ \\
\hline Sulfates & Gypsum & Thenardite \\
\hline Carbonates & $\begin{array}{l}\text { Calcite } \\
\text { Dolomite } \\
\text { Siderite }\end{array}$ & $\begin{array}{l}\text { Aragonite } \\
\text { Ankerite }\end{array}$ \\
\hline Silica & Quartz & - \\
\hline Oxides & - & $\begin{array}{l}\text { Hematite } \\
\text { Rutile }\end{array}$ \\
\hline Micas & - & $\begin{array}{l}\text { Muscovite } \\
\text { Chlorites }\end{array}$ \\
\hline Feldspar & - & Plagioclase \\
\hline Alunites & - & Jarosite \\
\hline
\end{tabular}

In decreasing abundance from top down.

and $\mathrm{F}$ and $\mathrm{Hg}$ in clays. Results from washability studies also suggest preferred associations among certain minerals and trace elements (Schultz et al. 1975; Deurbrouck and Jacobsen 1974; and Ruch et al. 1974); for example, $\mathrm{As}, \mathrm{Hg}, \mathrm{Pb}$, and $\mathrm{Cd}$ concentrate in the highest density washing fractions and are likely present in or as sulfide minerals. According to observations by Ruch et al. (1974), certain trace elements occur in coals as discrete micromineral phases such as $\mathrm{Cd}$ (sphalerit's), $\mathrm{Pb}$ (galena), and $\mathrm{F}$ (apatite). And, according to observations by Caruccio (1972), certain trace elements frequently occur in the various forms of pyrite present in coals.

Thus, there is considerable evidence that (1) trace elements in coals are associated mainly with the inorganic matter and (2) many of these elements are likely to be found with specific minerals (as opposed to being uniformly or randomly dispersed throughout the inorganic phases). 
Trace elements differ in their susceptibility to being removed from coal by density separation in coal washing. Nevertheless, significant amounts of these elements will collect in the coal washing refuse, which will have a higher concentration of these elements than is present in the feed coal.

\subsection{TRACE ELEMENTS INHERENT IN COAL}

Both natural and anthropogenic sources emit trace elements, mostly as airborne particulate matter, although some ( $\mathrm{Hg}$ and $\mathrm{Se}$ ) may enter the atmosphere as vapors.

Natural sources of airborne trace elements include the weathering of rocks and soils, volcanic eruptions, thermal spring activity, erosion of metal-rich surface deposits, reactions at water surfaces, forest fires, and plant growth (Swaine et al. 1988). Natural sources exceed anthropogenic sources for $\mathrm{Cr}, \mathrm{Co}, \mathrm{Mn}$, and Se (Nriagu 1990).

Anthropogenic sources of trace elements released to the atmosphere include electrical generation; mining operations; smelting; other industrial and commercial processes; waste incineration; combustion of wood, oil, and coal; agricultural operations; and tire and engine wear. Energy production, which includes fossil-fuel combustion in electrical power stations, is the largest single source of $\mathrm{Ni}$ and $\mathrm{Hg}$ emissions and the second largest global source of $\mathrm{Cd}, \mathrm{Sb}$, and Se emissions (Clarke and Sloss 1992). Fossil-fuel combustion generates an estimated $80 \%$ of the $\mathrm{Ni}, 60 \%$ of the $\mathrm{Hg}$ and $\mathrm{Se}$, and significant amounts of the $\mathrm{As}$ and $\mathrm{Sb}$ (Nriagu 1990) from anthropogenic sources. However, fossil-fuel combustion contributes only about $38 \%$ of the total $\mathrm{Hg}$ and about $52 \%$ of the total Ni from both natural and anthropogenic sources (Nriagu 1990).

Specific elements tend to associate with either organic material or discrete mineral grains. Those associated with the organic matter may be chemically bound to organic groups in the coal or may be finely disseminated mineral inclusions in the organic matrix. For example, according to many studies, Be has an affinity for the organic material.

Most trace elements are associated primarily with the mineral portion of the coal. Minerals vary from coal to coal, but aluminosilicates and silicates, carbonates, and sulfides are the major phases. Many elements of environmental concern, such as $\mathrm{As}, \mathrm{Cd}, \mathrm{Hg}, \mathrm{Pb}$, and Se, are typically associated with pyrite and other sulfide minerals. A higher proportion of organically bound trace elements appears in low-rank coals versus bituminous coals.

The elements identified in the 1990 CAAA are characterized and quantified below.

\subsubsection{Antimony}

Antimony (Sb) (atomic number 51, atomic mass 121.75) is listed as an HAP in the CAAA of 1990 (Table 1); is detected in fossil-fuel power plant flue gas by the EPRI (Boutacoff 1991); is slated to be assessed by the DOE (1992) as a toxic emission from coal-fired plants; and is listed by Swaine (1990) as a trace element that could be of environmental interest. 
Post combustion, $\mathrm{Sb}$ is preferentially concentrated in the fly ash fraction and exhibits pronounced concentiation in smaller fly ash particles (Szpunar et al. 1980). (See Table 5 for a summary of the postcombustion disposition for elements of interest.)

Antimony has no known function in living organisms and is not among the most toxic elements. It can have beneficial effects when used for medical reasons, such as treating humans infected with parasites. Exposure to Sb can cause irritations to the eyes, skin, and lungs, and can cause heart problems, vomiting, and diarrhea (DHHS 1990b). In large doses, it may produce heart disease and shortened life spans. However, no evidence of carcinogenesis or tumerogenesis has been obtained. On this basis, Sb should be considered to have a low inherent toxicity (Szpunar et al. 1980).

The low concentrations of $\mathrm{Sb}$ generally found in coals are not considered to be environmentally hazardous. The main sources of $\mathrm{Sb}$ in the atmosphere are metal smelting, waste incineration, and coal combustion (Austin and Millward 1988), while Sb has also been detected in emissions from Hawaiian volcanoes (Cadle et al. 1973). It is not clear how Sb occurs in coals, but it is likely that an organic association prevails in many coals, together with a sulfide association, which may predominate in others (Swaine 1990).

The range for most U.S. coals is from 0.04 to $16 \mathrm{ppm} \mathrm{Sb}$, but Appalachian bituminous and Rocky Mountain subbituminous coals may reach 35 to $43 \mathrm{ppm}$ (Zubovic et al. 1979) (Table 6). Typical (mean) concentrations by U.S. region range from $0.4 \mathrm{ppm}$ Sb (Rocky Mountain bituminous) to $2.1 \mathrm{ppm}$ (Alaskan subbituminous) (Swanson et al. 1976) and include Pennsylvanian anthracite at $1.1 \mathrm{ppm}$, Appalachian bituminous at $1.2 \mathrm{ppm}$, Interior bituminous at $1.7 \mathrm{ppm}$, Gulf lignite at $0.9 \mathrm{ppm}$, and Northern Plains lignite/subbituminous at $0.6 \mathrm{ppm}$ (Table 7).

TABLE 5 Trace Element Postcombustion Disposition

\begin{tabular}{ll}
\hline \multicolumn{1}{c}{ Element } & \multicolumn{1}{c}{ Disposition } \\
\hline $\mathrm{Cl}, \mathrm{F}$, and $\mathrm{Hg}$ & Primarily discharged to the atmosphere as a vapor. \\
$\mathrm{Sb}, \mathrm{As}, \mathrm{Cd}, \mathrm{Cr}, \mathrm{Pb}, \mathrm{Ni}$, and $\mathrm{Se}$ & $\begin{array}{l}\text { Preferentially concentrated in the fly ash, exhibiting } \\
\text { pronounced concentration in smaller particles. }\end{array}$ \\
$\mathrm{Be}$ & $\begin{array}{l}\text { Dual behavior: at times, preferentially concentrated in the } \\
\text { fly ash, exhibiting pronounced concentration in smaller } \\
\text { particles; at other times, distributed equally in the bottom } \\
\text { ash and fly ash. } \\
\mathrm{Co}, \mathrm{Mn}, \mathrm{Th}, \text { and } \mathrm{U}\end{array}$ \\
$\mathrm{P}$ & Distributed equally in the bottom ash and the fly ash. \\
& May be concentrated in the bottom ash. \\
\hline
\end{tabular}

a Ranked by importance to the atmosphere. 


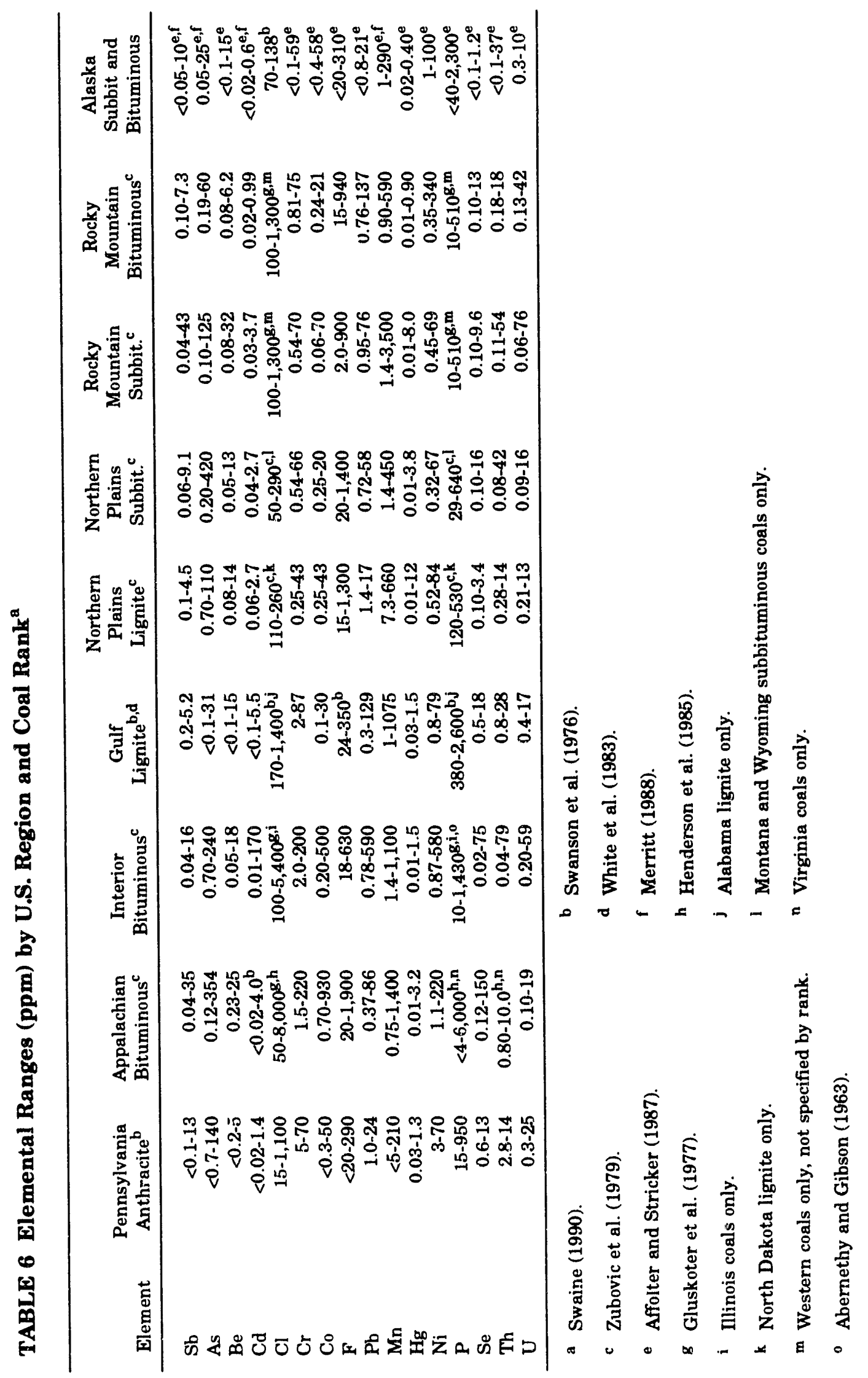




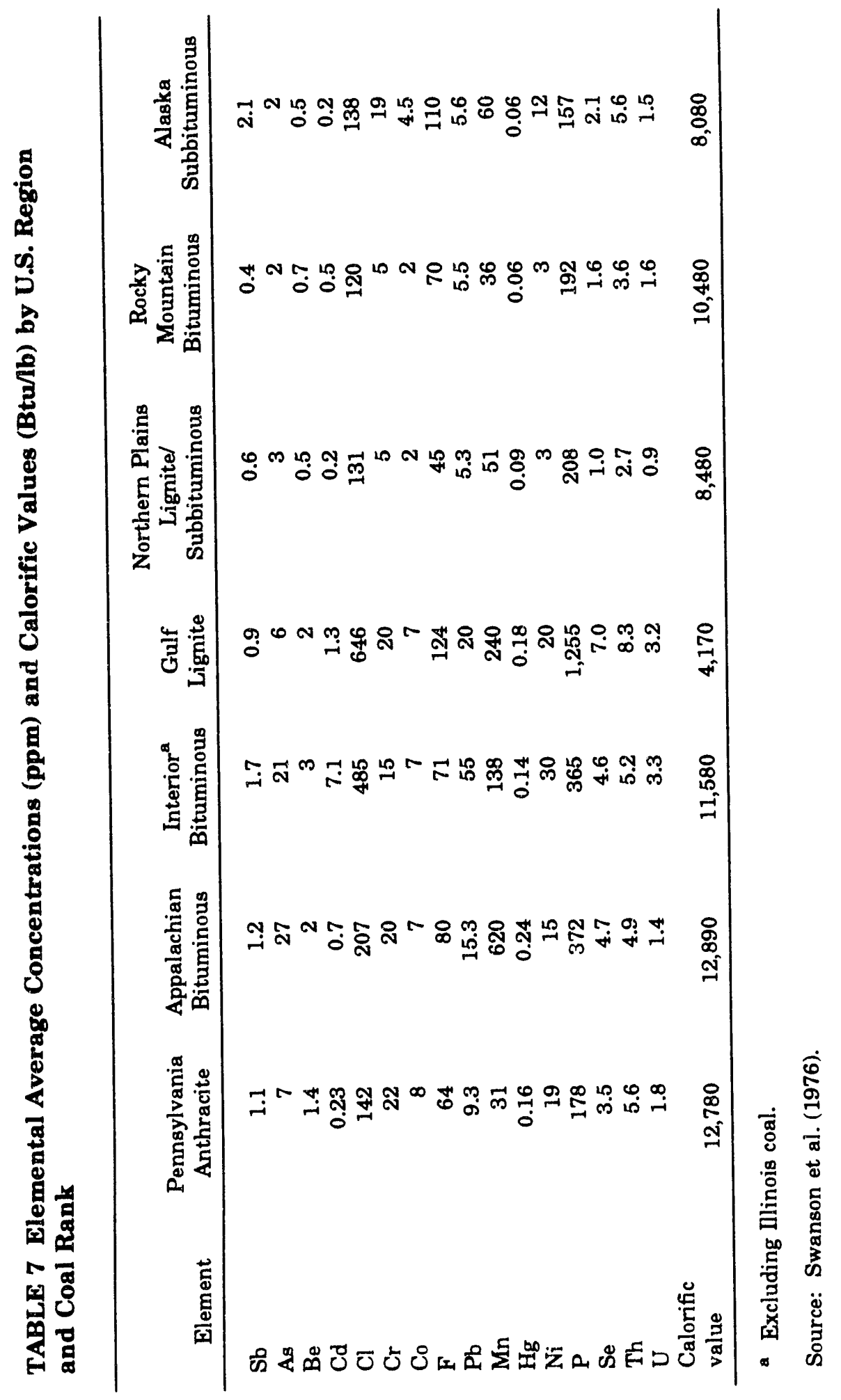


TABLE 8 Typical Elemental Concentrations of Coal Burned in EEC Power Stations (ppm)

\begin{tabular}{|c|c|c|c|c|c|c|}
\hline Element & Belgium & $\begin{array}{c}\text { West } \\
\text { Germany }\end{array}$ & France & U.K. & $\begin{array}{c}\text { Imported } \\
\text { Coal }^{\mathrm{a}}\end{array}$ & EEC Range \\
\hline $\mathrm{Sb}$ & 1.9 & 1.4 & 3.4 & 3.3 & 2.2 & $0.5-10$ \\
\hline As & 6.5 & 14.5 & 9.7 & 16.8 & 10 & $1.46-63.4$ \\
\hline $\mathrm{Be}$ & $\mathrm{NA}^{\mathrm{b}}$ & NA & NA & NA & NA & NA \\
\hline $\mathrm{Cd}$ & 0.5 & 0.5 & 0.5 & 0.3 & 0.5 & $<0.01-0.56$ \\
\hline Cl & NA & NA & NA & NA & NA & NA \\
\hline $\mathrm{Cr}$ & 60 & 25 & 36 & 32 & 44 & $6.4-260$ \\
\hline Co & NA & NA & NA & NA & NA & NA \\
\hline $\mathbf{F}$ & NA & NA & NA & NA & NA & NA \\
\hline $\mathrm{Pb}$ & 85 & 68 & 44 & 22 & 53 & $9.0-507$ \\
\hline $\mathrm{Mn}$ & NA & NA & NA & NA & NA & NA \\
\hline $\mathrm{Hg}$ & 0.38 & 0.4 & 0.2 & 0.28 & 0.28 & $0.025-1$ \\
\hline $\mathrm{Ni}$ & 55 & 45 & 38 & 38 & 38 & NA \\
\hline $\mathbf{P}$ & NA & NA & NA & NA & NA & $\mathbf{N A}$ \\
\hline Se & 1.6 & 1.5 & 1.3 & 2.8 & 1.7 & $0.3-5.05$ \\
\hline Th & 4.4 & 2.1 & 6.0 & 3.8 & 4.0 & $1.3-8.5$ \\
\hline $\mathrm{U}$ & 2.1 & 1.0 & 3.1 & 2.0 & 2.2 & $0.85-3.86$ \\
\hline
\end{tabular}

a For Denmark, Ireland, Italy, Luxembourg, and the Netherlands.

b $\mathrm{NA}=$ not available.

Source: Smith (1987).

The range for coal burned in European Economic Community (EEC) power stations is 0.5 to $10 \mathrm{ppm} \mathrm{Sb}$. Typical concentrations are the following: Belgium; $1.9 \mathrm{ppm}$; West Germany, 1.4 ppm; France, 3.4 ppm; the U.K., 3.3 ppm; and imported (Denmark, Ireland, Italy, Luxembourg, and the Netherlands), $2.2 \mathrm{ppm}$ (Smith 1987) (Table 8).

\subsubsection{Arsenic}

Arsenic (As) (atomic number 33, atomic mass 74.92) is listed as an HAP in the 1990 CAAA; is detected by the EPRI in fossil-fuel power plant flue gas (Boutacoff 1991) and is cited as an HAP (Mann et al. 1991); is cited by the EPA (1990a) in its draft source category list as a high-risk pollutant (1991), and as contributing to cancer risk from outdoor exposure (1990b); is slated to be assessed by the DOE (1992) as a toxic emission from coal-fired plants; and is listed by Swaine (1982) as a trace element of prime environmental interest. Post combustion, As is preferentially concentrated in the fly ash fraction and exhibits pronounced concentration in smaller fly ash particles (Szpunar et al. 1980) (Table 5).

In nature, As is ubiquitous and is found even in forest plants and wild animals that have supposedly never been exposed to arsenical pesticide residues, a prime source of As contamination until their use was phased out in the 1940 s. The levels of As in seafood are 
frequently in excess of established tolerance limits. Arsenicals have been used in medicine for 2,000 years, though their use is now largely discontinued. The carcinogenicity of As is the subject of considerable controversy. Arsenic has also been found to be the most effective antidote to excessive Se, and vice versa. Primary drinking water standards limit As to 0.05 ppm (Szpunar et al. 1980).

Since ancient times, As has been recognized as a human poison, and large doses can produce death. Lower levels of exposure may produce injury in a number of different body tissues or systems. By ingestion, a common effect in humans is irritation of the digestive tract, leading to pain, nausea, vomiting, and diarrhea; other effects include decreased production of red and white blood cells, abnormal heart function, blood vessel damage, liver and/or kidney injury, impaired nerve function causing a tingling feeling in the hands and feet, and skin abnormalities. Ingestion of As has been reported to increase the risk of cancer in the liver, bladder, kidneys, and lungs. Inhalation exposure may produce the same types of systemic health effects produced by ingestion, but in a much milder mode; of greater concern is lung cancer. Dermal contact may result in mild to severe irritation of the skin, eyes, or throat. On the other hand, despite all the adverse health effects associated with As exposure, there is some evidence that low levels of exposure may be beneficial to good health; although no cases of As deficiency in humans have been found, animal deficiencies have been documented (DHHS 1989b).

There has been increased interest in As in coals, as well as in rocks, soils, plants, and waste materials, probably because of possible adverse health effects of high concentrations (Swaine 1990). As with some other environmentally sensitive elements, coal tends to be seen as a major source of As, but it only contributes $1.8 \%$ of the total emissions to the atmosphere (Walsh et al. 1979), which is about the same as wood fuel. Volcanic emissions contain As (Cadle et al. 1973), and Greenland and Aruscavage (1986) estimated that about $10 \mathrm{t}$ As was emitted during eruptive emissions from Kilauea over a period of one year. Walsh et al. (1979) estimated that volcanoes contributed $22 \%$ of the total emissions of As to the atmosphere. Arsenic is most likely to be present in coal in the pyrite.

The range for most U.S. coals is from $<0.1$ to several hundred ppm As (Swaine 1990), but the Northern Plains subbituminous coals may reach $420 \mathrm{ppm}$ (Zubovic et al. 1979) (Table 6). Typical (mean) concentrations by U.S. region range from $2 \mathrm{ppm}$ As (Rocky Mountain ituminous and Alaskan subbituminous) to $27 \mathrm{ppm}$ (Appalachian bituminous) and include Pennsylvanian anthracite at $7 \mathrm{ppm}$, Interior bituminous at $21 \mathrm{ppm}$, Gulf lignite at $6 \mathrm{ppm}$, and Northern Plains lignite/subbituminous at 3 ppm (Table 7).

The range for coal burned in EEC power stations is 1.46 to $63.4 \mathrm{ppm}$ As. Typical concentrations are the following: Belgium, $6.5 \mathrm{ppm}$; West Germany, $14.5 \mathrm{ppm}$; France, $9.7 \mathrm{ppm}$; the U.K., $16.8 \mathrm{ppm}$; and imported (Denmark, Ireland, Italy, Luxembourg, and the Netherlands), 10 ppm (Smith 1987) (Table 8). 
A value above $80 \mathrm{ppm}$ As would seem to be unusual for feed coals used in power production. However, fly ash may contain several hundred ppm As, depending on the coal used. Thus, As content monitoring should be applied to landfills and leachate involved in fly ash deposition (Swaine 1990).

\subsubsection{Beryllium}

Beryllium (Be) (atomic number 4, atomic mass 9.01) is listed as an HAP in the 1990 CAAA; is detected by the EPRI in fossil-fuel power plant flue gas and is cited as an HAP; is cited by the EPA in its draft source category list and as a high-risk pollutant; is slated by the DOE/PETC as a toxic emission from coal-fired plants; and is listed by Swaine as a trace element that could be of environmental interest (references as previously cited). Beryllium and its compounds are on the carcinogen list of the Occupational Safety and Health Administration (OSHA) (Szpunar et al. 1980). Post combustion, Be has exhibited dual behavior - sometimes it preferentially concentrates in the fly ash fraction, exhibiting pronounced concentration in smaller fly ash particles; at other times, Be distributes equally in the bottom ash and the fly ash (EPA 1989) (Table 5).

Beryllium is a toxic substance that can be harmful, depending on the amount and duration of exposure. Not all of the effects that $\mathrm{Be}$ and its compounds have on human health are well understood, and not all forms of Be are equally toxic. Short-term human exposure to soluble Be compounds can lead to the development of inflammation and swelling of the lungs; removal from exposure results in a reversal of symptoms. Long-term exposure has been reported to cause chronic beryllium disease in sensitive individuals, characterized by shortness of breath, scarring of the lungs, and berylliosis (noncancerous growths in the lungs). Both acute and chronic beryllium disease can be fatal, depending on the severity of the exposure. Dermal contact may develop into a skin allergy in sensitized individuals; noncancerous growths may form on the skin if Be enters cuts. Although inhalation of Be and its compounds is presumed by the EPA to have some cancer-causing potential in the human lung, no studies in animals or humans provide convincing evidence that the ingestion of $\mathrm{Be}$ or its compounds causes cancer (DHHS 1988b).

It is generally considered that Be is organically associated in most coals; however, Be may appear in quartz and clay minerals associated with coal (Swaine 1990). According to Fishbein (1981), "Be in the environment chiefly arises from coal combustion." Despite this finding, a careful study by Gladney and Owens (1976) showed that "less than $4 \%$ of the $\mathrm{Be}$ in the coal burned is being emitted to the atmosphere."

The range for most U.S. coals is from 0.05 to $18 \mathrm{ppm}$ Be (Swaine 1990), but Appalachian bituminous and Rocky Mountain subbituminous coals may reach 25 to $32 \mathrm{ppm}$ (Zubovic et al. 1979) (Table 6). Typical (mean) concentrations by U.S. region range from $0.5 \mathrm{ppm}$ Be (Northern Plains lignite/subbituminous and Alaskan subbituminous) to $3 \mathrm{ppm}$ (Interior bituminous) and include Pennsylvanian anthracite at $1.4 \mathrm{ppm}$, Appalachian bituminous and Gulf lignite at 2 ppm, and Rocky Mountain bituminous at $0.7 \mathrm{ppm}$ (Table 7). 


\subsubsection{Cadmium}

Cadmium (Cd) (atomic number 48, atomiz mass 112.40) is listed as an HAP in the 1990 CAAA; is detected by the EPRI in fossil-fuel power plant flue gas and is cited as an HAP; is cited by the EPA in its draft source category list, as a high-risk pollutant, and as contributing to cancer risk from outdoor exposure; is slated by the DOE/PETC as a toxic emission from coal-fired plants; and is listed by Swaine as a trace element of prime environmental interest. $\mathrm{Cd}$ is on OSHA's carcinogen list. Post combustion, $\mathrm{Cd}$ is preferentially concentrated in the fly ash fraction and exhibits pronounced concentration in smaller fly ash particles (Szpunar et al, 1980) (Table 5).

Cadmium enters the biosphere through its increasing use in electroplating, in plastics as stabilizers, in paints as pigments, in Cd batteries, as a contaminant in phosphate fertilizers and sewage sludges, and in waste incineration. Coal combustion contributes about one-tenth of the amount emitted by volcanoes (Nriagu 1979). Cadmium is toxic to virtually every system in the animal body, whether ingested, injected, or inhaled. Schroeder (1967) showed a positive correlation between the Cd levels in air in U.S. cities and the incidence of cardiovascular diseases in those cities. The disease of itai-itai in Japan has now been well documented as caused by the ingestion of $\mathrm{Cd}, \mathrm{Zn}$, and $\mathrm{Pb}$ from mining operations. Primary drinking water standards limit Cd concentrations to $0.01 \mathrm{ppm}$ (Szpunar et al. 1980).

Cadmium is not known to have any beneficial effects but can cause a number of adverse health effects. Ingestion of high doses causes severe irritation to the stomach, leading to vomiting and diarrhea; inhalation of high doses leads to severe irritation of the lungs. Of greater concern is long-term, low-level exposure causing kidney and lung damage and lung cancer. Exposure injures the liver, the testes, the immune system, the nervous system, and the blood. A low but prolonged intake of $\mathrm{Cd}$ is suspected to lead to hypertension and reduced longevity in laboratory animals (DHHS 1989c).

Much is known about the harmful effects of Cd, especially from areas contaminated by some industrial wastes. It is currently an element of prime environmental concern and, hence, the levels of $\mathrm{Cd}$ in coal and coal-related materials are of interest. It is generally accepted that the main mode of occurrence of $\mathrm{Cd}$ in most coals is "... in solid solution, replacing $\mathrm{Zn}$ in the mineral sphalerite" (Gluskoter and Lindahl 1973). However, Cd is also associated with clay minerals and carbonate minerals, and it is known that pyrite may contain some $\mathrm{Cd}$ (Kirsch et al. 1980). Only minor amounts of $\mathrm{Cd}$ are organically associated in most coals, although possibly more in lower-rank coals (due to reaction with hydroxyl groups) (Swaine 1990).

The range for most U.S. coals is from 0.01 to $5 \mathrm{ppm} \mathrm{Cd,} \mathrm{but} \mathrm{Interior} \mathrm{bituminous} \mathrm{coals}$ may reach $170 \mathrm{ppm}$ (Zubovic et al. 1979) (Table 6). Typical (mean) concentrations by U.S. region range from $0.2 \mathrm{ppm} \mathrm{Cd}$ (Pennsylvanian anthracite, Northern Plains lignite/subbituminous, and Alaskan subbituminous) to $7 \mathrm{ppm}$ (Interior bituminous) and include Appalachian bituminous at $0.7 \mathrm{ppm}$, Gulf lignite at $1.3 \mathrm{ppm}$, and Rocky Mountain bituminous at $0.5 \mathrm{ppm}$ (Table 7 ). 
The range for coal burned in EEC power stations is $<0.01$ to $0.56 \mathrm{ppm} \mathrm{Cd}$. Typical concentrations are the following: Belgium, $0.5 \mathrm{ppm}$; West Germany, $0.5 \mathrm{ppm}$; France, 0.5 ppm; the U.K., 0.3 ppm; and imported (Denmark, Ireland, Italy, Luxembourg, and the Netherlands), $0.5 \mathrm{ppm}$ (Smith 1987) (Table 8).

Where low-S coals, and ipso facto usually low-Cd coals, are being used for power production, it would appear that coal combustion is only a minor source of environmental $\mathrm{Cd}$.

\subsubsection{Chlorine}

Chlorine (Cl) (atomic number 17, atomic mass 35.453 ) is listed as an HAP in the 1990 CAAA; is detected by the EPRI in fossil-fuel power plant flue gas and is cited as an HAP; is slated by the DOE/PETC as a toxic emission from coal-fired plants; and is listed by Swaine as a trace element that could be of environmental interest. Post combustion, $\mathrm{Cl}$ has primarily been considered to be discharged to the atmosphere as a vapor (Szpunar et al. 1980) (Table 5).

Long-term interest in $\mathrm{Cl}$ in coal has stemmed from the fact that relatively high $\mathrm{Cl}$ tends to be associated with deposits on boiler tubes in equipment using mechanical stokers. However, Wandless (1958) has suggested that coals with $<3,000 \mathrm{ppm} \mathrm{Cl}$ are unlikely to produce troublesome deposits in the boiler (in the convection tube area). But more importantly, high-Cl coals may give rise to corrosion of furnace walls and superheater tubes, probably because of the formation of $\mathrm{HCl}$. Collins (1990) states: "Available data indicate that chlorides can accelerate fireside corrosion in boilers. Depending upon the specific fuel chemistry and boiler conditions, its effect can be substantial. ... To combat the increased corrosion associated with high-Cl coals, mild steel tubes with thicker-than-normal front wall can be specified. Improved alloys ... are another option."

It has been estimated that coal combustion is the largest anthropogenic source of $\mathrm{Cl}$, producing, for example, about $75 \%$ of the $\mathrm{HCl}$ emitted in western Europe (with the remainder from waste incineration) (Lightowlers and Cape 1988). However, this $\mathrm{HCl}$ appears to be only a minor contributor (about $2 \%$ ) to acidity in the atmosphere. Relevant natural sources of $\mathrm{HCl}$ are volcanoes and methyl chloride, which reacts with hydroxyl radicals to eventually produce $\mathrm{HCl}$ in the atmosphere (Swaine 1990).

There has been much debate about the mode of occurrence of $\mathrm{Cl}$. It is most likely that $\mathrm{Cl}$ is somehow associated with the organic coaly matter (Martinez-Tarazona et al. 1988; Finkelman 1981; and Saunders 1980) as organochlorine compounds. The original suggestion of the predominance of inorganic $\mathrm{Cl}$ in Illinois coals (Gluskoter and Rees 1964) was modified subsequently by Gluskoter and Ruch (1971) to favor organically bound Cl. However, "the nature of the chlorine-coal bond is still uncertain" (Hodges et al. 1983). 
The high volatility of the free or inorganically bound $\mathrm{Cl}$ present in coal means that, at the temperatures present in most combustion zones, $\mathrm{Cl}$ is released as acidic gas ( $\mathrm{HCl}$ ). More complex mineral forms and organically bound portions are not released as easily and may remain in the bottom ash or may be released on fine particles. For pulverized-coal firing, the emission factor is approximately, 99\%. And low- $\mathrm{NO}_{\mathrm{x}}$ burners probably have no effect on $\mathrm{Cl}$ partitioning (Sloss 1992). But removal by flue-gas desulfurization (FGD) has been estimated at $90 \%$ (Meij 1991).

The range for most U.S. coals is from 15 to $1,400 \mathrm{ppin} \mathrm{Cl}$, but there are notable exceptions - Appalachian bituminous at $8,000 \mathrm{ppm}$ and Interior bituminous at 5,400 pprn (Henderson et al. 1985; Gluskoter et al. 1977) (Table 6). Typical (mean) concentrations by U.S. region range from $120 \mathrm{ppm} \mathrm{Cl}$ (Rocky Mountain bituminous) to $646 \mathrm{ppm}$ (Gulf liønite) and include Pennsylvanian anthracite at 142 ppm, Appalachian bituminous at 207 ppm, Interior bituminous at $485 \mathrm{ppm}$, Northern Plains lignite/subbituminous at $131 \mathrm{ppm}$, and Alaskan subbituminous at $138 \mathrm{ppm}$ (Table 7). Data on 6,000 coal samples collected by the U.S. Geological Survey (USGS) support these concentrations but indicate that coals in Appalachia and the Interior have the highest average $\mathrm{Cl}$ concentration for U.S. coal at 500 ppm (Collins 1990).

$\mathrm{Cl}$ in coal would probably not have significant negative health effects, but it may cause corrosion, as noted above (Swaine 1990), thereby affecting unit, operability.

\subsubsection{Chromium}

Chromium (Cr) (atomic number 24, atomic mass 52.00) is listed as an HAP in the 1990 CAAA; is detected by the EPRI in fossil-fuel power plant flue gas and is cited as an HAP; is cited by the EPA in its draft source category list, as a high-risk pollutant, and as contributing to cancer risk from outdoor exposure; is slated by the DOE/PETC as a toxic emission from coal-fired plants; and is listed by Swaine as a trace element of prime environmental interest. Post combustion, $\mathrm{Cr}$ is preferentially concentrated in the fly ash fraction and exhibits pronounced concentration in smaller fly ash particles (Szpunar et al. 1980) (Table 5).

Chromium is a naturally occurring element that is found in soil, volcanic dust, and gases. Primary drinking water standards limit total $\mathrm{Cr}$ to $0.05 \mathrm{ppm}$ (Szpunar et al. 1980). Chromium is found in the environment in three major states: metallic $\mathrm{Cr}$, trivalent $\mathrm{Cr}$ $\left(\mathrm{Cr}^{+3}\right)$, and hexavalent $\mathrm{Cr}\left(\mathrm{Cr}^{+6}\right)$.

Metallic $\mathrm{Cr}$ is generally produced by industrial processes. However, exposure to metallic $\mathrm{Cr}$ is not well characterized.

Trivalent $\mathrm{Cr}$ occurs naturally and is considered an essential nutrient required for normal metabolism of carbohydrate, glucose, cholesterol, and fat in humans. Signs of $\mathrm{Cr}^{+3}$ deficiency in humans include weight loss and impairment of the body's ability to remove 
glucose from the blood. The minimum human daily requirement of $\mathrm{Cr}^{+3}$ for optimal health is not known, but ingestion of 50-200 $\mu \mathrm{g} / \mathrm{d}$ has been estimated to be safe and adequate. Brewer's yeast and fresh foods are good sources of $\mathrm{Cr}^{+3}$ (DHHS 1989e).

Although short-term exposure to $\mathrm{Cr}^{+3}$ does not result in adverse health effects, very large doses of $\mathrm{Cr}^{+3}$ may prove harmful (DHHS 1989e). Although $\mathrm{Cr}^{+3}$ occurs naturally in soil, volcanic dust, and gases, it has not been found to be toxic, even when associated with wastewaters and industrial discharges.

In general, $\mathrm{Cr}^{+6}$ is also produced by industrial processes. Short-term exposure to $\mathrm{Cr}^{+6}$ can result in adverse effects at the site of contact, such as ulcers of the skin, irritation of the nasal mucosa, perforation of the nasal septum, and irritation of the gastrointestinal tract. It may also cause adverse effects in the kidney and liver. Long-term exposure to workers to airborme levels of $\mathrm{Cr}^{+6}$ has been associated with lung cancer, occurring long after exposure to $\mathrm{Cr}^{+6}$ has ended. Compounds of $\mathrm{Cr}^{+6}$ are regarded as probable carcinogens in humans exposed by inhalation. Inhalation exposure to $\mathrm{Cr}^{+6}$ may also result in adverse effects on the respiratory system and may affect the immune system (DHHS 1989e).

Hexavalent $\mathrm{Cr}$ occurs in some wastewaters and industrial situations but not usually in coal mining or usage. Because $\mathrm{Cr}^{+6}$ has been found to be toxic, it is the likely form of concern for the residual risk phase of the Section 112 CAA regulation.

Coal combustion is a source of $\mathrm{Cr}$ in the atmosphere, but volcanoes "emit large amounts" of $\mathrm{Cr}$ (Nriagu et al. 1988, pp. 125-172). The mode of occurrence of $\mathrm{Cr}$ is not certain, but association with clays (in the mineral matter) is reasonable, together with the possibility of finely divided chromites in some coals (Finkelman 1981). Given and Miller (1987) have suggested that $\mathrm{Cr}$ may be partly complexed with organic matter in some U.S. lignites and other low-rank coals (Swaine 1990).

The range for most U.S. coals is from 0.25 to $87 \mathrm{ppm} \mathrm{Cr}$, but there are notable exceptions - Appalachian bituminous at $220 \mathrm{ppm}$ and Interior bituminous at $200 \mathrm{ppm}$ (Zubovic et al. 1979) (Table 6). Typical (mean) concentrations by U.S. region range narrowly from $5 \mathrm{ppm} \mathrm{Cr}$ (Northern Plains lignite/subbituminous and Rocky Mountain bituminous) to $22 \mathrm{ppm}$ (Pennsylvanian anthracite) and include Appalachian bituminous and Gulf lignite at $20 \mathrm{ppm}$, Interior bituminous at $15 \mathrm{ppm}$, and Alaskan subbituminous at $19 \mathrm{ppm}$ (Table 7).

The range for coal burned in EEC power stations is 6.4 to $260 \mathrm{ppm} \mathrm{Cr}$. Typical concentrations are the following: Belgium, 60 ppm; West Germany, 25 ppm; France, 36 ppm; the U.K., $32 \mathrm{ppm}$; and imported (Denmark, Ireland, Italy, Luxembourg, and the Netherlands), 44 ppm (Smith 1987) (Table 8). 


\subsubsection{Cobalt}

Cobalt (Co) (atomic number 27, atomic mass 58.93) is listed as an HAP in the 1990 CAAA; is detected by the EPRI in fossil-fuel power plant flue gas and is cited as an HAP; is slated by the LOE/PETC as a toxic emission from coal-fired plants; and is listed by Swaine as a trace element that could be of environmental interest. Post combustion, Co is distributed equally in the bottom ash and the fly ash (Szpunar et al. 1980) (Table 5).

Cobalt has an important role in nutrition and is an integral part of vitamin $B_{12}$ (cyanocobalmin), a vitamin essential to maintain human health. Co has also been used as a treatment for anemia. And Co-60 in radiation treatment is used to kill cancer cells. Although higher levels of $\mathrm{Co}$ and some of its compounds are harmful, it is not as potent as $\mathrm{Ni}$ in inducing malignancies. For all species studied, it apparently has a very low order of toxicity (Szpunar et al. 1980). And, although Co is considered by some researchers to be carcinogenic, no route of exposure in humans or animals has been proven (DHHS 1990c). Workplace exposure seriously affects the lungs (asthma, pneumonia, and wheezing); allergies can develop that result in asthma and skin rashes. From 1960 until fairly recently, during which time breweries added Co to beer to stabilize the foam, heavy beer drinkers had experienced vomiting, nausea, and serious heart effects, some resulting in death.

It appears that Co may occur in coal associated with the mineral matter (linnaeite, other sulfides, and clay) (Swaine 1990) and with the organic matter (Finkelman 1981; Gluskoter et al. 1977; and Zubovic et al. 1961).

The range for most U.S. coals is from 0.1 to $70 \mathrm{ppm} \mathrm{Co}$, but there are notable exceptions - Appalachian bituminous at $930 \mathrm{ppm}$ and Interior bituminous at $500 \mathrm{ppm}$ (Zubovic et al. 1979) (Table 6). Typical (mean) U.S. concentrations range narrowly from $2 \mathrm{ppm}$ Co (in the West) to $8 \mathrm{ppm}$ (Pennsylvanian anthracite) and include Appalachian bituminous, Interior bituminous, and Gulf lignite at $7 \mathrm{ppm}$ and Alaskan subbituminous at 5 ppm (Table 7).

\subsubsection{Fluorine}

Fluorine (F) (atomic number 9, atomic mass 19.00) is listed as an HAP in the 1990 CAAA; is detected by the EPRI in fossil-fuel power plant flue gas and is cited as an HAP; is slated by the DOE/PETC as a toxic emission from coal-fired plants; and is listed by Swaine as a trace element of prime environmental interest. Post combustion, like $\mathrm{Cl}, \mathrm{F}$ has been considered to be discharged to the atmosphere primarily as a vapor (Szpunar et al. 1980) (Table 5).

Fluorine is preferentially concentrated in the bones and teeth; $98.9 \%$ of the body's content is found there. It is most well known in its controversial role in the prevention of dental caries. Higher F levels, however, will mottle the teeth (Szpunar et al. 1980). 
Fluorine is an element of great environmental interest because of its biological role and because it may be harmful under certain conditions. The mode of occurrence of $F$ in coal is in the mineral matter. According to Swaine (1990), the relative contribution from coal burning seems to be unknown, and research is needed to ascertain the fate of $\mathrm{F}$ during the combustion of coal in modern power stations. Sloss (1992), however, claims that the majority of $\mathrm{F}$ present in coal is released as a gas (HF) during combustion, with only a small percentage $(<1 \%)$ being retained in the bottom ash. A small percentage of the HF in the flue gas may adsorb to fly ash particles before emission from the stack. Fluorine may be present in two distinct forms that behave differently during the combustion process. The first is the water and acid soluble fraction (emitted in the vapor phase as HF), and the second is the water and acid insoluble fraction (inert during combustion and, thus, remaining in the ash). For pulverized-coal firing, the emission factor is approximately $90 \%$. And low- $\mathrm{NO}_{\mathrm{x}}$ burners probably have no effect on F partitioning (Sloss 1992). But removal by FGD has been estimated at 70\% (Meij 1991).

The range for most U.S. coals is from 15 to $1,400 \mathrm{ppm} \mathrm{F}$, but Appalachian bituminous is somewhat higher at $1,900 \mathrm{ppm}$ (Zubovic et al. 1979) (Table 6). Typical (mean) concentrations by U.S. region range narrowly from $45 \mathrm{ppm} F$ (Northern Plains lignite/subbituminous) to $124 \mathrm{ppm}$ (Gulf lignite) and include Pennsylvanian anthracite at $64 \mathrm{ppm}$, Appalachian bituminous at $80 \mathrm{ppm}$, Interior bituminous at $71 \mathrm{ppm}$, Rocky Mountain bituminous at $70 \mathrm{ppm}$, and Alaskan subbituminous at $110 \mathrm{ppm}$ (Table 7).

\subsubsection{Lead}

Lead $(\mathrm{Pb})$ (atomic number 82, atomic mass 207.19) is listed as an HAP in the 1990 CAAA; is detected by the EPRI in fossil-fuel power plant flue gas and is cited as an HAP; is cited by the EPA in its draft source category list; is slated by the DOE/PETC as a toxic emission from coal-fired plants; and is listed by $\mathrm{Sw}$ ine as a trace element of prime environmental interest. Post combustion, $\mathrm{Pb}$ is preferenually concentrated in the fly ash fraction and exhibits pronounced concentration in smaller fly ash particles (Szpunar et al. 1980) (Table 5).

There is probably no other element (besides $\mathrm{Hg}$ ) on which greater research efforts have been spent. The long-standing problem of $\mathrm{Pb}$ toxicity in humans has been well documented. Airborne $\mathrm{Pb}$ from automobile exhausts and from pumping gasoline is a particular point of concern. People with more than $0.5 \mathrm{ppm} \mathrm{Pb}$ in their blood show visible signs of $\mathrm{Pb}$ poisoning - constipation, headaches, anemia, paralysis, blindness, insanity, and, finally, at higher levels, death. Also, $\mathrm{Pb}$ can cause sterility, miscarriage, still births, infant mortality, and mental retardation. It has been postulated that the collapse of the Roman Empire was caused, in part, by the $\mathrm{Pb}$ poisoning of tiie ruling upper classes who consumed wine prepared and stored in $\mathrm{Pb}$-lined vessels.

There is no well-established role for $\mathrm{Pb}$ as an essential trace element in nutrition. $\mathrm{O}_{1}$, the other hand, $\mathrm{Pb}$ is a well-known cumulative poison in humans. Lead can enter the body by inhalation or ingestion, but much less $\mathrm{Pb}$ enters through the skin than through the 
lungs or gastrointestinal tract. Regardless of how $\mathrm{Pb}$ enters the body, most of it is stored in the bone. And because some $\mathrm{Pb}$ is stored in the body each time a person is exposed, the levels of $\mathrm{Pb}$ in bone and teeth increase as one gets older. Unstored $\mathrm{Pb}$ is removed through the excretory system (DHHS 1990a).

The effects of $\mathrm{Pb}$ are the same no matter how it enters the body. Exposure is especially dangerous for the unborn because their bodies can be harmed while they are being formed, resulting in premature birth, low birth weight, or spontaneous abortion. Young children are at risk because they may ingest significant amounts of $\mathrm{Pb}$ when they put toys or other objects soiled with $\mathrm{Pb}$-containing dirt in their mouths. Most of the $\mathrm{Pb}$ swallowed by children enters their bodies, and they are especially sensitive to its effects. For infants or young children, exposure has been shown to decrease intelligence scores, to retard growth, and to cause hearing problems. These effects appear to last as children get older and can interfere with successful performance in school. Moreover, these health effects can occur at exposure levels once thought to be safe. Hence, primary drinking water standards limit $\mathrm{Pb}$ concentration to $0.05 \mathrm{ppm}$ (Szpunar et al. 1980).

Exposure to high levels of $\mathrm{Pb}$ can cause brain and kidiney damage in acults and children, may increase blood pressure in middle-aged mer, and may affect the male reproductive system, especially sperm. Pica, a cl.eldren's disease, is caused by ingesting :-'b paints from household walls. Lead hav not been shown to cause cancer in humans, although the grnwth of tumors in laboratory animals exposed to $\mathrm{Pb}$ indicates that possibility (DHHS 1990a). Nevertheless, several $\mathrm{Pb}$ compounds am on OSHA's carcinogen list. Organic compounds, especially $\mathrm{Pb}$ alkyls, are even more poiscnous than inorganic compounds of $\mathrm{Pb}$. Therefore, because of the wide array of organic compuunds possibly emitted from coal-fired combustion, $\mathrm{Pb}$ poses a potentially significant threat to human beings

There appears to be litile dispute abcut the occurrence of $\mathrm{Ph}$ in the mineral matter of coal, although $23 \%$ of the $\mathrm{Pb}$ in some Polish coals is in the organic matter (Marczak and Parzentny 1985). Finkelman (1988, 1981) has associated $\mathrm{Pb}$ with galena (FoS), with some $\mathrm{Ba}$ minerals, where $\mathrm{Pb}$ can replace $\mathrm{Ba}$ (in sulfates, carbonates, phosphates, and silicates), and with pyrites. Organic association probably occurs in lor -rank coals (Swaine 1990). According to Patterson and Settle (1987), the emission of $\mathrm{Pb}$ from volcanoes is relatively small but is still very similar to that from coal burning (Bennett 1981).

The range for most U.S. coals is from 0.03 to $137 \mathrm{ppm} \mathrm{Pb}$, but Interior bituminous coals may reach $590 \mathrm{ppm}$ (Zubovic et al. 1979) (Table 6). Typical (mean) concentrations by U.S. region range from $5 \mathrm{ppm} \mathrm{Pb}$ (Northern Plains lignite/subbituminous) to t5 $\mathrm{ppm}$ (Interior bituminous) and include Pennsylvanian at $9 \mathrm{ppm}$, Appalachian bituminous at $15 \mathrm{ppm}$, Gulf lignite at $20 \mathrm{ppm}$, and Rocky Mountain bituminous and Alaskan subbituminous at $6 \mathrm{ppm}$ (Table 7).

The range for coal burned in EEC power stations is 9.0 to $507 \mathrm{ppm} \mathrm{Pb}$. Typical concentrations are the following: Belgium, 85 ppm; West Germany, 68 ppm; France, 44 ppm; the U.K., 22 ppm; and imported (Denmark, Ireland, Italy, Luxembourg, and the Netherlands): 53 ppm (Smith 1987) (Table 8). 


\subsubsection{Manganese}

Manganese (Mn) (atomic number 25, atomic mass 54.94) is listed as an HAP in the 1990 CAAA; is detected by the EPRI in fossil-fuel power plant flue gas and is cited as an HAP; is cited by the EPA in its draft source category list; is slated by the DOE/PETC as a toxic emission from coal-fired plants; and is listed by Swaine as a trace element that could be of environmental interest. Post combustion, Mn is distributed equally in the bottom ash and fly ash (Szpunar et al. 1980) (Table 5).

About 2,500-5,000 $\mathrm{gg} / \mathrm{d} \mathrm{Mn}$ is required for growth, bone formation, maintenance of reproductive functions, and glucose, lipid, and other metabolic functions. Many enzymes are activated by $\mathrm{Mr}$, which is among the least toxic of the trace elements to mammals and birds. On the other $\mathrm{l}, \mathrm{ld}$, excessive and extended exposure to $\mathrm{Mn}$ in the workplace has been shown to cause permanent injury to a part of the brain responsible for mental and emotional disturbances in humans; the resulting slow and clumsy body movements are symptoms of a disease called manganism. And males who are exposed to a high level of $\mathrm{Mn}$ may experience impotence. There is little evidence to suggest that Mn causes cancer. And, although humans cannot taste $\mathrm{Mn}$ in water at less than about $5 \mathrm{ppm}$, secondary drinking water standards limit its concentration to 0.05 ppm (DHHS 1990d; Szpunar et al. 1980).

There is interest in $\mathrm{Mn}$ because of its biological essentiality and because an excess can cause environmental problems. For most low-rank coals, the predominant mode of occurrence is organic. For higher rank coals, there are several modes, namely, in carbonate rainerals, in clays, in pyrite, and as organically bound $\mathrm{Mn}$, although the latter two modes are considered to be minor jources (Swaine 1990).

The range ior most U.S. coals is from 1 to $1,400 \mathrm{ppm} \mathrm{Mn,} \mathrm{but} \mathrm{Rocky} \mathrm{Mountain}$ bituminous soals may reach $3,500 \mathrm{ppm}$ (Zubovic et al. 1979) (Table 6). Typical (mean) concentrations by U.S. region range from $31 \mathrm{ppm} \mathrm{Mn}$ (Pennsylvanian anthracite) to $620 \mathrm{ppm}$ (Appalachian bituminous) and include Interior bituminous at $138 \mathrm{ppm}$, Gulf lignite at $240 \mathrm{ppm}$, Northern Plains lignite/subbiiuminous at $51 \mathrm{ppm}$, Rocky Mountain bituminous at $36 \mathrm{ppm}$, and Alaskan subbituminous at $60 \mathrm{ppm}$ (Table 7).

\subsubsection{Mercury}

Tercury (Hg) (atomic number 80, atomic mass 200.59) is listed as an HAP in the 1990 CAAA; is detected by the EPRI in fossil-fuel power plant flue gas and is cited as an HAP; is cited by the EPA in its draft source category list and as a high-risk pollutant; is slated by the DOE/PETC as a toxic emission from coal-fired plants; and is listed by Swaine as a trace element of prime enviror.mental interest. Post combustion, like $\mathrm{F}$ and $\mathrm{Cl}, \mathrm{Hg}$ has primarily been considered to be discharged to the atmosphere as a vapor (Szpunar et al. 1980) (Table 5).

Mercury is not a carcinogen, but it is toxic to animals and humans at even very low levels. Mercury poisoning, however, was quite prevalent, even during earlier times in certain 
professions. The expression "mad as a hatter" describes the symptoms exhibited by hat makers engaged in treating furs with mercury nitrate. During the early 1960s, widespread toxicity in Japan was traced to high $\mathrm{Hg}$ levels in the fish from Minamata Bay. Over the years, incidents of widespread $\mathrm{Hg}$ contamination have been observed in fish in Nigata, Japan, in bird populations in Sweden, in grain in Iraq, and in lakes and fish in the U.S.-Canadian Great Lakes area. At $0.2 \mathrm{ppm}$ blood level, overt neurological symptoms of $\mathrm{Hg}$ intoxication may occur - numbness and tingling of hands, feet, or lips, ataxia, constricted visual field, emotional disturbances, and others. Methyl mercury, which is formed from the inorganic $\mathrm{Hg}$ compounds in nature, is a highly toxic substance that causes neurological damage, produces chromosomal aberrations, and has teratogenic effects. Primary drinking water standards limit $\mathrm{Hg}$ content to $0.002 \mathrm{ppm}$ (2 ppb) (Szpunar et al. 1980) (Table 5).

Mercury may enter the body through inhalation, ingestion, or skin absorption. Once $\mathrm{Hg}$ has entered the body, it may be months before all of it leaves via the excretory system. Long-term exposure to either organic or inorganic $\mathrm{Hg}$ can permanently damage the brain, kidneys, and developing fetuses. The form of $\mathrm{Hg}$ and the way humans are exposed determine which health effects will predominate. For example, organic $\mathrm{Hg}$ that is eaten in contaminated fish or grain may cause greater harm to the brain and developing fetuses than to the kidney; breathed metallic $\mathrm{Hg}$ vapor may cause greater harm to the brain than to the kidneys; and inorganic $\mathrm{Hg}$ salts that are eaten in contaminated food or drunk in water may cause greater harm to the kidneys than to the brain. Thus, maternal exposure to organic $\mathrm{Hg}$ may lead to brain damage in fetuses; while adults exposed to metallic $\mathrm{Hg}$ may develop shakiness and tremors, memory loss, and kidney disease. Short-term exposure to high levels of inorganic and organic $\mathrm{Hg}$ will have similar health effects; but full recovery is more likely after short-term exposures, once the body clears itself of the contamination (DHHS 1989h).

Important natural sources of $\mathrm{Hg}$ contribute to the atmospheric concentrations volcanoes (Varekamp and Buseck 1986; Cadle et al. 1973; and Eshleman et al. 1971); volatilization from vascular plants (Kama and Siegel 1980); and degassing from land and water surfaces (Swaine 1990). Apart from coal, there are several industrial sources of $\mathrm{Hg}$ (Airey 1982), including cement-making (Fukuzaki et al. 1986) and cremation (Swaine 1984).

Extensive studies of Donbas and other Soviet coals led Dvornikov (1981a,b) to propose that $\mathrm{Hg}$ occurs in three forms, namely, mercuric sulfide ( $\mathrm{HgS}$ ), metallic (elemental) $\mathrm{Hg}$, and organomercury compounds. Mercury has been found in sphalerite from the Illinois Basin. Finkelman et al. (1979) have found a good correlation between $\mathrm{Hg}$ and pyritic S. Porritt and Swaine (1976) and Ruch et al. (1971) have found incomplete evidence for a $\mathrm{Hg}$-pyrite association. Thus, $\mathrm{Hg}$ in coals is probably associated with pyrite and sometimes sphalerite, with organically bound $\mathrm{Hg}$ still an uncertainty (Swaine 1990).

The range for most U.S. coals is from 0.01 to $4 \mathrm{ppm} \mathrm{Hg}$, but Rocky Mountain subbituminous coal may reach $8 \mathrm{ppm}$, and Northern Plains lignite may reach 12 ppm (Zubovic et al. 1979) (Table 6). Typical (mean) concentrations by U.S. region range narrowly from $0.06 \mathrm{ppm} \mathrm{Hg}$ (Rocky Mountain bituminous and Alaskan subbituminous) to $0.24 \mathrm{ppm}$ (Appalachian bituminous) and include Pennsylvanian anthracite at $0.16 \mathrm{ppm}$, Interior 
bituminous at $0.14 \mathrm{ppm}$, Gulf lignite at $0.18 \mathrm{ppm}$, and Northern Plains lignite/subbituminous at $0.09 \mathrm{ppm}$ (Table 7).

The high results and mean value of $3.3 \mathrm{ppm}$ obtained for $\mathrm{Hg}$ in some U.S. coals by Joensuu (1971) are not regarded as representative, and even the mean value of $1 \mathrm{ppm} \mathrm{Hg}$ used in the calculation of the global release of $\mathrm{Hg}$ from coal burning is much too high. Nevertheless, this high estimate is still quoted widely in papers dealing with the global cycling of $\mathrm{Hg}$ (Swaine 1990).

Despite the generally held finding that $\mathrm{Hg}$ is primarily discharged to the atmosphere as a vapor upon the combustion of coal, Diehl et al. (1972) and Swaine (1977) have reported varying amounts of $\mathrm{Hg}$ in fly ash. This occurrence may be the result of longer residence times and/or system recycling in advanced technology configurations. Moreover, Swaine (1990) contends that the often naive assumptions about releases of trace elements from coal burning, including $\mathrm{Hg}$, may be based on incorrect data and a poor understanding of operational matters. Since modern power stations aim at removing at least $99 \%$ of the fly ash, it is clear that any calculation of the $\mathrm{Hg}$ released from coal must take into consideration the $\mathrm{Hg}$ in fly ash. To that end, more measurements and further study of the $\mathrm{Hg}$ partitioning mechanism appear warranted.

The range for coal burned in EEC power stations is 0.025 to $1 \mathrm{ppm} \mathrm{Hg}$. Typical concentrations are the following: Belgium, $0.38 \mathrm{ppm}$; West Germany, $0.4 \mathrm{ppm}$; France, $0.2 \mathrm{ppm}$; the U.K., $0.28 \mathrm{ppm}$; and imported (Denmark, Ireland, Italy, Luxembourg, and the Netherlands), $0.28 \mathrm{ppm}$ (Smith 1987) (Table 8).

Mercury is the only trace element for which information on trends in atmospheric concentrations is currently available. According to Slemr and Langer (1992), the atmospheric concentration of $\mathrm{Hg}$ increased at an annual rate of $1.46 \pm 0.17 \%$ in the Northern Hemisphere and $1.17 \pm 0.16 \%$ in the Southern Hemisphere during the period 1977 to 1990 . The highest $\mathrm{Hg}$ concentrations are evident at between $40^{\circ}$ and $60^{\circ}$ latitude. This area of the Northern Hemisphere contains mcit of the industrialized nations - Canada, the countries of Europe, and the United States.

\subsubsection{Nickel}

Nickel (Ni) (atomic number 28, atomic mass 58.71) is listed as an HAP in the 1990 CAAA; is detected by the EPRI in fossil-fuel power plant flue gas and is cited as an HAP; is cited by the EPA in its draft source category list; is slated by the DOE/PETC as a toxic emission from coal-fired plants; and is listed by Swaine as a trace element of prime environmental interest. Nickel and its compounds are on OSHA's carcinogen list. Post combustion, $\mathrm{Ni}$ is preferentially concentrated in the fly ash fraction and exhibits pronounced concentration in smaller fly ash particles (Szpunar et al. 1980) (Table 5). 
Exposure to $\mathrm{Ni}$ and its compounds results from breathing air, ingesting drinking water and food that contain $\mathrm{Ni}$ and its compounds, and skin contact with a wide range of consumer products. Very small amounts of $\mathrm{Ni}$ have been shown to be essential for normal growth and reproduction in some species of animals; thus, small amounts of $\mathrm{Ni}$ are also thought to be essential to nutrition in humans. Nickel is a cofactor of the enzyme urease and can substitute for calcium (Ca) in some processes (DHHS 1988c; Szpunar et al. 1980).

The most common adverse effects of $\mathrm{Ni}$ exposure noted in the general population are skin allergies. Surveys indicate that $2.5-5.0 \%$ of the population may be sensitive to $\mathrm{Ni}$. Individuals may be sensitized by frequent or prolonged contact with $\mathrm{Ni}$-containing or $\mathrm{Ni}$-plated consumer products such as jewelry. However, in persons not sensitive to $\mathrm{Ni}$, normal long-term oral, inhalation, and skin exposures to low levels of $\mathrm{Ni}$ have not been associated with adverse health effects. Accidental or suicidal ingestion of very high amounts of some $\mathrm{Ni}$ compounds (but not $\mathrm{Ni}$ metal) may result in death.

Inhalation in the workplace has produced asthma in Ni platers exposed to nickel sulfate $\left(\mathrm{NiSO}_{4}\right)$ and in welders exposed to nickel oxide $\left(\mathrm{NiO}_{\mathrm{x}}\right)$. From the inhalation of $\mathrm{Ni}$ refinery dust, which contains nickel subsulfide, increased deaths from lung and nasal cavity cancers and possible voice-box cancer have been reported; but there are no Ni refineries in the United States and, hence, no Ni refinery dust and no nickel subsulfide (DHHS 1988c).

The carcinogenesis of $\mathrm{Ni}$ is inversely related to the solubility of its compounds, and the least soluble in aqueous media appear to be the most carcinogenic. Nickel carbonyl ( $\mathrm{NiCO}$ ) has been implicated as a possible carcinogen in metal workers and tobacco smokers (Szpunar et al. 1980).

Among the natural sources of $\mathrm{Ni}$ to the atmosphere are volcanoes (Cadle et al. 1973) and windblown dusts, each supplying several times that emitted by coal combustion, which constitutes about 1.5\% of the global emission of $\mathrm{Ni}$ in the atmosphere (Bennett 1982). The primary modes of occurrence of $\mathrm{Ni}$ in coal are probably in association with sulfides, organically, and, possibly, in clays (Swaine 1990).

The range for most U.S. coals is from 0.3 to $100 \mathrm{ppm} \mathrm{Ni}$, but Interior bituminous may reach $580 \mathrm{ppm}$, Rocky Mountain bituminous coal $340 \mathrm{ppm}$, and Appalachian bituminous coal 220 ppm (Zubovic et al. 1979) (Table 6). Typical (mean) concentrations by U.S. region range narrowly from $3 \mathrm{ppm} \mathrm{Ni}$ (in the West) to $30 \mathrm{ppm}$ (Interior bituminous) and include Pennsylvanian anthracite at $19 \mathrm{ppm}$, Appalachian bituminous at $15 \mathrm{ppm}$, Gulf lignite at $20 \mathrm{ppm}$, and Alaskan subbituminous at $12 \mathrm{ppm}$ (Table 7).

Typical concentrations for $\mathrm{Ni}$ in coal burned in EEC power stations are the following: Belgium, 55 ppm; West Germany, 45 ppm; France, 38 ppm; the U.K., 38 ppm; and imported (Denmark, Ireland, Italy, Luxembourg, and the Netherlands), 38 ppm (Smith 1987) (Table 8). 


\subsubsection{Phosphorus}

Phosphorus (P) (atomic number 15, atomic mass 30.97 ) is listed as an HAP in the 1990 CAAA; is detected by the EPRI in fossil-fuel power plant flue gas and is cited as an HAP; and is cited by the EPA in its draft source category list. Post combustion, P probably ends up as a phosphate in the bottom ash (Table 5).

Specific data are not currently available about health effects related to $\mathrm{P}$ or its compounds and coal-fired combustion with subsequent emission to the atmosphere.

Because the concentration of $P$ in coal is often below $1,000 \mathrm{ppm}$, it is regarded as a trace element. However, $\mathrm{P}$, along with nine other elements $-\mathrm{Na}, \mathrm{Ca}$, magnesium $(\mathrm{Mg})$, potassium (K), aluminum ( $\mathrm{Al}$ ), silicon ( $\mathrm{Si})$, iron ( $\mathrm{Fe}$ ), titanium ( $\mathrm{Ti})$, and $\mathrm{S}-$ is analyzed routinely as a minor element in coal and is reported as the oxide of coal ash (by convention)." In particular, there are thousands of determinations of $P$ in coal and coal ash that are carried out because of the importance of $P$ in coke for steel making. However, most of these results are not published. Finkelman (1981) has concluded that $P$ is likely to be present in most coals as a phosphate, although a smaller but uncertain proportion occurs as organic $P$ (Swaine 1990).

The range for most I..S. coals is from 10 to 2,600 ppm $P$, but a notable exception, Appalachian bituminous (Virginia coals only), may reach 6,000 ppm (Henderson et al. 1985) (Table 6). Typical (mean) concentrations by U.S. region range from 157 ppm P (Alaskan subbituminous) to $1,255 \mathrm{ppm}$ (Gulf lignite) and include Pennsylvanian anthracite at $178 \mathrm{ppm}$, Appalachian bituminous at $372 \mathrm{ppm}$, Interior bituminous at $365 \mathrm{ppm}$, Northern Plains lignite/subbituminous at 208 ppm, and Rocky Mountain bituminous at $192 \mathrm{ppm}$ (Table 7).

The elemental pattern for $\mathrm{P}$ is similar to $\mathrm{Cl}$ in U.S. coal, as noted above.

\subsubsection{Selenium}

Selenium (Se) (atomic number 34, atomic mass 78.96) is listed as an HAP in the 1990 CAAA; is detected by the EPRI in fossil-fuel power plant flue gas and is cited as an HAP; is cited by the EPA in its draft source category list; is slated by the DOE/PETC as a toxic emission from coal-fired plants; and is listed by Swaine as a trace element of prime environmental interest. Post combustion, Se is preferentially concentrated in the fly ash fraction and exhibits pronounced concentration in smaller fly ash particles (Szpunar et al. 1980) (Table 5).

\footnotetext{
*"Relationships between the behavior of ash in coal-processing operations and ash composition have been developed by establishing an empirical equation that relates some parameter of behavior to the amounts of 'oxides' in the ash. Such empirical equations have sometimes successfully predicted ash behavior from ash composition. However, they provide few insights into the actual chemical basis for the observed behavior because elements generally do not occur in ash as their oxides" (Schobert 1987).
} 
Selenium toxicity has been known since Marco Polo's time when his horses' hooves fell off after ingesting Se-accumulating plants. (Plants easily take up Se compounds from water and convert them to organic Se compounds such as selenomethionine.) However, Se is a very important element nutritionally; the relationship has been demonstrated between methionine, vitamin $\mathrm{E}_{1}$, and $\mathrm{Se}$ (at about 50-150 $\mu \mathrm{g} / \mathrm{d}$ ) as an essential nutrient. In humans, Se helps prevent damage by oxygen to tissue, as does vitamin $\mathrm{E}$.

An interesting feature of the environmental behavior of Se is that the difference between a concentration causing deficiency and that which may be harmful is relatively small: the ratio between its essential (nutritional) character and its toxic character is 1:100. Primary drinking water standards limit Se to $0.01 \mathrm{ppm}$. Se compounds (including those used in some medicated dandruff shampoos) are not absorbed well through the skin. There is little information on health effects from Se inhalation, and no studies have confirmed death from inhalation (DHHS 1989j; Szpunar et al. 1980).

Mercury is known to be a Se-antagonist in the form of methyl $\mathrm{Hg}\left(\mathrm{CH}_{3} \mathrm{Hg}^{+}\right)$, which occurs in certain seafoods. The diminished physiological activity of Se in fishmeal may be related to its high chemical affinity for $\mathrm{Hg}$. In China, there are widespread areas where Se deficiency is considered to be a factor in two diseases, namely, Keshan disease (an endemic cardiomyopathy) and Kashin-Beck disease (an endemic osteoarthropathy). Because seafood is so significant in the Asian diet and may contain especially high levels of $\mathrm{Hg}$, the nutritional activity of Se may be blocked. Hence, these diseases may affect millions of people (Levander 1987).

Ingesting large amounts of sodium selenate $\left(\mathrm{Na}_{2} \mathrm{SeO}_{4}\right)$ or sodium selenite $\left(\mathrm{Na}_{2} \mathrm{SeO}_{3}\right)$ could be life threatening without immediate treatment. If amounts of Se only somewhat higher than needed were eaten over long periods of time, several health effects could occur including brittle hair, deformed nails, and, in extreme cases, loss of feeling and control in extremities (DHHS 1989j).

Although coal burning contributes a high proportion of the Se in the atmosphere (Andren, Klein, and Talmi 1975), there are several important natural sources including volcanoes (Greenland and Aruscavage 1986; Cadle et al. 1973), volatilization from soils and plants (Zieve and Peterson 1984), and from ocean surfaces (Mosher and Duce 1983). Biomethylation of Se is an important mechanism for the cycling of Se (Cooke and Bruland 1987). Lag and Steinnes (1978) concluded that "anthropogenic Se was not the major source of the atmospheric input and that natural mechanisms must be responsible for this process" in Norway.

There are several modes of occurrence of Se in coal. Pyrite is a host for Se (Minkin et al. 1984). Finkelman (1981) discovered lead selenide (PbSe), probably in clausthalite, in coals from the Appalachian Basin. Oman et al. (1988, pp. 16-17) found organically bound Se in coals from the Powder River Basin. Thus, Se occurs in coal organically associated - in pyrite (probably in solid solution), in galena (as PbSe), and possibly in clays (Swaine 1990). 
The range for most U.S. coals is from 0.1 to $18 \mathrm{ppm}$ Se, but Appalachian bituminous coals may reach $150 \mathrm{ppm}$, and Interior bituminous coals may reach $75 \mathrm{ppm}$ (Zubovic et al. 1979) (Table 6). Typical (mean) concentrations by U.S. region range from $1.0 \mathrm{ppm}$ Se (Northern Plains lignite/subbituminous) to $7.0 \mathrm{ppm}$ (Gulf lignite) and include Pennsylvanian anthracite at $3.5 \mathrm{ppm}$, Appalachian bituminous at $4.7 \mathrm{ppm}$, Interior bituminous at $4.6 \mathrm{ppm}$, Rocky Mountain bituminous at $1.6 \mathrm{ppm}$, and Alaskan subbituminous at $2.1 \mathrm{ppm}$ (Table 7).

For nine countries of the European Community (EC), coals used in power production had a mean of $1.7 \mathrm{ppm}$ Se (Sabbioni and Goetz 1983). The range for coal burned in EEC power stations is 0.3 to $5.05 \mathrm{ppm}$ Se. Typical concentrations are the following: Belgium, $1.6 \mathrm{ppm}$; West Germany, $1.5 \mathrm{ppm}$; France, $1.3 \mathrm{ppm}$; the U.K., $2.8 \mathrm{ppm}$; and imported (Denmark, Ireland, Italy, Luxembourg, and the Netherlands), 1.7 ppm (Smith 1987) (Tahle 8).

Knowledge of Se in coal is needed to properly understand the geochemical cycle of Se and to avoid problems that could arise from the disposal of fly ash or the use of fly ash as a soil amendment (Swaine 1990). Knowledge of leachability (of Se as well as the other trace elements of interest) is also relevant.

\subsubsection{Radionuclides}

As a group, the radionuclides are listed as HAPs in the 1990 CAAA; are cited by the EPA as contributing to cancer risk from outdoor exposure; are slated by the DOE/PETC as toxic emissions from coal-fired plants; and are listed by Swaine as trace elements that could be of environmental interest. They include Th (atomic number 90, atomic mass 232.04), $\mathrm{U}$ (atomic number 92, atomic mass 238.03), and $\mathrm{Rn}$ (atomic number 86, atomic mass 222.0). Post combustion, Th and $U$ are distributed equally in the bottom ash and the fly ash (EPA 1989; Szpunar et al. 1980) (Table 5). Radon is a gas formed from the radioactive decay of $U$.

The metals Th and $U$ contribute to the radioactivity in coal and are, therefore, of interest biologically and environmentally. Both elements are present in U.S. coal at trace levels but not exceeding $100 \mathrm{ppm}$. They originate as residues left from the vegetation that formed the coal and from the associated minerals. Western U.S. coals generally contain higher amounts of $U$ resulting from epigenetic effects (groundwater working on volcanic rocks carrying dissolved $U$ into lignites near the surface) (Szpunar et al. 1980). Radon is derived from $U$ as a product of normal radioactive decay (DHHS 1990i).

Although the radiation from coal firing has been regarded as an order of magnitude higher than that from an equivalent nuclear plant, these doses are in the range of natural background (Mishra et al. 1984). Wagner et al. (1980) found that radioactivity in coal was generally about the same as that in most rocks and soils. Moreover, radiation exposure from coal-fired and nuclear power plants corresponds to $<1 \%$ of the average natural background radiation (Jacobi et al. 1982) and represents "... a very small augmentation of the natural background" (Corbett 1983, confirmed later by Salmon et al. 1984). Furthermore, coals from 
the western United States do "... not present any significant radiological hazard" (Abbott et al. 1983). However, before burning coal with more than about $30 \mathrm{ppm} U$, one should check the emissions and the solid waste products produced (Swaine 1990).

\subsubsection{Thorium}

Only a small amount of the thorium (Th) that a human inhales or ingests in food, water, or soil enters the blood. After breathing Th, one will usually sneeze, cough, or breathe out some of it within minutes. Although some forms of Th can stay in the lungs for long periods of time, almost all of it exits the body through the excretory system within days. However, the small amount left in the body may enter the bones from the blood and will stay there for many years.

After many years, exposure to Th in the workplace may cause increased chance of developing lung disease and cancer of the lung or pancreas. Changes in the genes have been shown to occur in workers who breathed Th dust. Liver diseases, blood effects, and cancer have also been shown to occur in people many years after Th was injected into their bodies for medical testing purposes. Thorium is not known, however, to cause birth defects or to affect the ability to conceive children (DHHS 1990e).

Thorium is associated with mineral matter in most coals, perhaps as monazite, with lesser amounts in zircon and xenotime (Swaine 1990).

The range for U.S. coals is from 0.04 to $79 \mathrm{ppm} \mathrm{Th}$, which is also the range for Interior bituminous coals (Zubovic et al. 1979) (Table 6). Typical (mean) concentrations by U.S. region range from $2.7 \mathrm{ppm}$ Th (Northern Plains lignite/subbituminous) to $8.3 \mathrm{ppm}$ (Gulf lignite) and include Pennsylvanian anthracite and Alaskan subbituminous at $5.6 \mathrm{ppm}$, Appalachian bituminous at $4.9 \mathrm{ppm}$, Interior bituminous at $5.2 \mathrm{ppm}$, and Rocky Mountain bituminous at $3.6 \mathrm{ppm}$ (Table 7 ).

For nine countries of the EC, coals used in power production had a mean of $4 \mathrm{ppm}$ Th (Sabbioni and Goetz 1983). The range for coal burned in EEC power stations is 1.3 to $8.5 \mathrm{ppm}$ Th. Typical Th concentrations are the following: Belgium, $4.4 \mathrm{ppm}$; West Germany, $2.1 \mathrm{ppm}$; France, $6.0 \mathrm{ppm}$; the U.K., $3.8 \mathrm{ppm}$; and imported (Denmark, Ireland, Italy, Luxembourg, and the Netherlands), $4.0 \mathrm{ppm}$ (Table 8).

\subsubsection{Uranium}

When uranium (U) dust is inhaled, most of it exits the lungs in coughs or exhalations. However, some is swallowed after breathing; that portion enters the blood, passes through the kidneys, and is eliminated within a few days. A small amount may reside in the lungs for years. About $99 \%$ of normally ingested $U$ exits through the excretory system within a few days, never passing through the blood. The $1 \%$ enters the blood, passes through the kidneys, and is eliminated in a few days. A small amount moves to the bone and may 
reside there for years. Uranium is not known to cause birth defects, to affect the ability to conceive children, or to pose a danger to human health in its natural state and at its natural level; and natural $U$ has not been shown to cause cancer in humans or animals. Nevertheless, greater exposure to enriched $U$, which has been made more radioactive, is thought to increase the chance of developing cancer (DHHS 1990j).

It seems that $U$ was carried into the coal swamps in solution as carbonate complexes (Breger et al. 1955a), which then released uranyl ions to form uranyl-organic complexes. In many coals, especially low-U coals, $U$ is predominantly organically bound (Breger et al. 1955b). A small amount of $U$ could be associated with clay (Swaine 1990). Finkelman (1981) found $U$ associated with the minerals zircon, phosphate, uraninite, apatite, rutile, and calcite.

The range for U.S. coals is from 0.06 to $76 \mathrm{ppm} \mathrm{U}$, but the Rocky Mountain subbituminous coals exhibit the widest range (Zubovic et al. 1979) (Table 6). Typical (mean) concentrations by U.S. region range from $0.9 \mathrm{ppm} \mathrm{U}$ (Northern Plains lignite/subbituminous) to $3.3 \mathrm{ppm}$ (Interior bituminous) and include Pennsylvanian anthracite at $1.8 \mathrm{ppm}$, Appalachian bituminous at $1.4 \mathrm{ppm}$, Gulf lignite at $3.2 \mathrm{ppm}$, Rocky Mountain bituminous at $1.6 \mathrm{ppm}$, and Alaskan subbituminous at $1.5 \mathrm{ppm}$ (Table 7).

For nine countries of the EC, coals used in power production had a mean of $2 \mathrm{ppm}$ $\mathrm{U}$ (Sabbioni and Goetz 1983). The range for coal burned in EEC power stations is 0.85 to $3.86 \mathrm{ppm} U$. Typical $U$ concentrations are the following: Belgium, $2.1 \mathrm{ppm}$; West Germany, $1.0 \mathrm{ppm}$; France, $3.1 \mathrm{ppm}$; the U.K., $2.0 \mathrm{ppm}$; and imported (Denmark, Ireland, Italy, Luxembourg, and the Netherlands), $2.2 \mathrm{ppm}$ (Smith 1987) (Table 8).

\subsubsection{Radon}

Radon $(\mathrm{Rn})$ is a naturally occurring, colorless, odorless, tasteless, radioactive gas that is formed from the normal decay of $U$. It slowly breaks down to other products such as radium $(\mathrm{Ra})$, which breaks down to $\mathrm{Rn}$. Radon also undergoes radioactive decay and has a half-life of about four days.

Inhalation is the primary mode of exposure. Cracks in the foundation or basement of a house may allow for increased exposure to Rn. After inhaled, most is breathed out immediately. However, some $\mathrm{Rn}$ remains in the lungs and undergoes radioactive decay. The radiation released during this process passes into lung tissue and is the cause of lung damage. Ingested Rn from drinking water passes through the walls of the stomach and intestine. After entering the blood, more than $90 \%$ of the $\mathrm{Rn}$ is exhaled shortly after having been inhaled. The rest undergoes decay.

Long-term exposure in air increases the chance of developing lung cancer (DHHS 1990i).

No coal data are available for Rn from the sources cited herein. 


\subsection{ORGANIC COMPOUNDS DERIVED FROM COAL UPON COMBUSTION}

Although difficult to characterize and quantify, the HAPs derived from trace element emissions are somewhat straightforward because they vary primarily by fuel source. The effect of combustion on the trace elements in coal will be discussed in Section 5 .

The emissions of organic HAPs, on the other hand, depend far more heavily on boiler configuration and operating conditions. Hence, these are even more difficult to identify and quantify. Neverth :ess, selected organic compounds identified as CAA HAPs are characterized below. those organic compounds presented here represent the intersection of the combined EPA sets with the combined EPRI sets (Table 3: [columns 2+3+4] intersection [columns $6+7$ ]). That is, the organic compounds considered important by this author and characterized below are identified:

1. As a CAAA HAP,

2. As a pollutant in some fashion by the EPA, and

3. As an EPRI-identified emission derived specifically from fossil-fuel combustion or as an EPRI-identified HAP - hence, of potential significance in the regulation of electric utilities.

Although naphthalene and the subclass of PAHs contained in the broad, generic category of POM do not meet the definition ${ }^{*}$ stated above, these organic compounds are also characterized below.

\subsubsection{Acetaldehyde}

Acetaldehyde $\left(\mathrm{CH}_{3} \mathrm{CHO}\right)$ is a colorless liquid, is highly flammable, and has a pungent, fruity odor. It is soluble in water, alcohol, ether, benzene, gasoline, solvent naphtha, toluene, xylene, turpentine, and acetone (Hawley 1977). It is biodegradable in water (National Research Council 1977). Acetaldehyde is derived from the oxidation of ethylene, the vapor-phase oxidation of ethanol, the vapor-phase oxidation of propane and butane, or the direct conversion of ethylene. It is used in the manufacture of acetic acid, acetic anhydride, n-butanol, 2-ethylhexanol, 1,3-butylene glycol, synthetic resins, and various dyes.

Acetaldehyde is toxic. In animals, inhaling it results in mild upper-respiratory-tract irritation and inhibition of the central nervous system; also, exposure causes eye irritation and conjunctivitis. Human exposure to acetaldehyde probably antedates recorded history. (For example, it is a major metabolite of ethyl alcohol and is present in tobacco smoke.) There have not been systematic studies bearing directly on the effect of acetaldehyde in

\footnotetext{
"Specifically, they are not identified as pollutants by the EPA.
} 
humans, although the effects of ethyl alcohol may be indicative of the effects of acetaldehyde (National Research Council 1977).

\subsubsection{Benzene}

Benzene $\left(\mathrm{C}_{6} \mathrm{H}_{6}\right)$, one of the high-volume chemicals produced in the United States, is a flammable, colorless to light-yellow, mobile, nonpolar liquid of highly refractive nature with an aromatic odor. It is soluble in alcohol, ether, acetone, carbon tetrachloride, carbon disulfide, and acetic acid and slightly soluble in water (Hawley 1977). It is derived from the hydrodealkylation of toluene, the pyrolysis of gasoline, the transalkylation of toluene by disproportionation reaction, the catalytic reforming of petroleum, the fractional distillation of coal tar, or as a by-product of coking coal (National Research Council 1977). It is used in ethylbenzene (for styrene monomer), dodecylbenzene (for detergents), cyclohexane (for nylon), phenol, nitrobenzene (for aniline), maleic anhydride, chlorobenzene, diphenyl, benzene hexachloride, benzenesulfonic acid, solvents, and antiknock gasoline.

Benzene is toxic by ingestion, inhalation, and skin absorption. Single oral or inhalation exposures to benzene at $20,000 \mathrm{ppm}$ have proven to be fatal in humans. Industrial air concentrations of benzene have been reported to give rise to giddiness, drowsiness, dizziness, headache, nausea, convulsions, unconsciousness, and paralysis (DHHS 1989d; National Research Council 1977).

From overwhelming human evidence and supporting animal studies, benzene is known to be a human carcinogen. Leukemia (cancer of the tissues that form the white blood cells) and subsequent death from cancer have occurred in some workers exposed to benzene for periods of less than 5 and up to 30 years. Long-term exposures $t_{c}$ wenzene may affect normal blood production, possibly resulting in severe anemia and internal bleeding. Studies indicate that benzene is harmful to the immune system, increasing the chance for infections and perhaps lowering the body's defense against tumors. Exposure to benzene has also been linked with genetic changes (DHHS 1989d).

\subsubsection{Benxidine}

Benzidine $\left(\mathrm{NH}_{2}\left[\mathrm{C}_{6} \mathrm{H}_{4}\right]_{2} \mathrm{NH}_{2}\right)$ is a grayish-yellow, white, or reddish gray crystalline powder; it is soluble in hot water, alcohol, and ether and slightly soluble in water (Hawley 1977). It is derived by reducing nitrobenzene with zinc dust in an alkaline solution followed by distillation, by electrolysis of nitrobenzene followed by distillation, or by nitration of diphenyl followed by reduction of the product with zinc dust in alkaline solution with subsequent distillation. It is used in organic synthesis, the manufacture of dyes, especially of Congo red, detection of blood stains, stain in microscopy, reagents, and stiffening agents in rubber compounding. It is considered in the generic class of POM with dibenzofuran (Mann et al. 1991). 
Benzidine is toxic by ingestion, inhalation, and skin absorption and is carcinogenic. Acute (short-term) exposure in large amounts can cause skin rashes, irritation, and damage to certain body tissues and organs such as the bladder. It may also cause bloody urine. Long-term exposure can result in bladder damage (lesions), which may progress to invasive cancer, if not found and treated in the early stages. Humans differ in their ability to resist the effects of long-term exposure to benzidine; averaging about 16 to 18 years, the time it takes to develop symptoms may vary from a few years to over 40 . The time required for the developmeat, of cancer decreases as the level of exposure increases (DHHS 1989f).

\subsubsection{Carbon Tetrachloride}

Carbon tetrachloride $\left(\mathrm{CCl}_{4}\right)$ is a chlorinated hydrocarbon and a colorless liquid with a sweetish, distinctive odor. It is soluble in alcohol, ether, chloroform, benzene, solvent naphtha, and most of the fixed and volatile oils, and it is insoluble in water (Hawley 1977). It is derived from the interaction of carbon disulfide and $\mathrm{Cl}$ in the presence of $\mathrm{Fe}$ or the chlorination of methane or higher hydrocarbons at $250-400^{\circ} \mathrm{C}$. It decomposes to phosgene (carbonyl chloride, $\mathrm{COCl}_{2}$ ) at high temperature. It is used in refrigerants and propellants, especially the chlorofluorohydrocarbons, metal degreasing, agricultural fumigants, chlorinating organic compounds, and production of semiconductors.

Carbon tetrachloride is highly toxic by ingestion, inhalation, and skin absorption. It is rapidly and readily absorbed from the gastrointestinal tract and by inhalation through the lungs. A fatal dose for children has been reported to be as low as $3 \mathrm{~mL}$, but there is great variation in individual susceptibility. The liver is especially sensitive to carbon tetrachloride; the kidney is also sensitive to it, with the main effect being a slowdown in urine formation, leading to a buildup of waste products in the blood. Some humans exposed to carbon tetrachloride will develop severe liver damage with little or no evidence of renal involvement, while others will suffer renal shutdown. In eight instances of either acute or subacute poisoning, seven patients suffered renal insufficiency and six of these required dialysis. Although two died from heart failure, none of the six survivors showed any evidence of liver damage (DHHS 1989g; National Research Council 1977).

Chronic exposures of 45 to $100 \mathrm{ppm}$ usually result in symptoms of gastrointestinal upset such as nausea and vomiting and nervous system symptoms such as headache, dizziness, drowsiness, and excessive fatigue. Exposures of 100 to $300 \mathrm{ppm}$ add apathy, mental confusion, and/or weight loss to the gastointestinal symptoms.

\subsubsection{Chloroform}

Chloroform (trichloromethane, $\mathrm{CHCl}_{3}$ ) is a clear, colorless, highly refractive, heavy, volatile liquid with a characteristic odor and a sweet taste, soluble in alcohol, ether, benzene, solvent naphtha, fixed and volatile oils and slightly soluble in water (Hawley 1977). It is not biodegradable in water (National Research Council 1977). It is derived from the reaction of chlorinated lime with acetone, acetaldehyde, or ethyl alcohol or is a by-product from the 
chlorination of methane. The National Cancer Institute has found that chloroform causes cancer in rats and mice; thus, the Food and Drug Administration (FDA) has banned its use in drugs, cosmetics, and food packaging, including cough medicines, toothpastes, etc. It is used in fluorocarbon refrigerants and aerosol propellants, fluorocarbon plastics and resins, solvents, analytical chemistry procedures, fumigants, and insecticides.

Chloroform is toxic by inhalation, and prolonged inhalation or ingestion may be fatal. It affects the central nervous system, liver, and kidneys. It was used as a surgical anesthetic for many years before its harmful effects on the liver and kidneys were recognized. Shortterm exposure to high concentrations in the air causes tiredness, dizziness, and headache. Longer-term exposure to high levels of chloroform in the air, or in food and drinking water, can affect liver and kidney function. Toxic effects may include jaundice and burning urination. High doses of chloroform have also been found to cause liver and kidney cancer in experimental animals (DHHS 1989a). The recommended occupational exposure to chloroform should not exceed $10 \mathrm{ppm}$ average exposure in a 10-hour day (National Research Council 1977).

\subsubsection{Dibenzofuran}

Dibenzofuran (diphenylene oxide, $\mathrm{C}_{12} \mathrm{H}_{8} \mathrm{O}$ ) is a tricyclic crystalline solid, insoluble in water and slightly soluble in alcohol, ether, and benzene (Hawley 1977). It is derived from coal tar. It is used in insecticides. It is considered in the generic class of POM with benzidine (Mann et al. 1991).

Although dibenzofuran is probably toxic, no toxicological profile was found for it at this time.

\subsubsection{Formaldehyde}

Formaldyhyde (oxymethylene, formic aldehyde, methan :l, HCHO) is a readily polymerizable gas with a strong, pungent odor, soluble in water and alcohol. It is commercially offered as a 37 to $50 \%$ aqueous solution, which may contain up to $15 \%$ methanol to inhibit polymerization. These commercial grades are referred to as formalin. It is one of the few organic compounds known to exist in outer space (Hawley 1577). It is derived from the oxidation of synthetic methanol or low-boiling petroleum gases such as propane and butane by means of silver, copper, or an iron-molybdenum oxide catalyst. It is used in urea and melamine resins, polyacetal resins, phenolic resins, ethylene glycol, pentaerythritol, hexamethylenetetramine, fertilizers, dyes, disinfectants, germicides, embalming fluids, preservatives, hardening agents, reducing agents, gold and silver recovery, oil well corrosion inhibitors, and durable-press treatment of textile fabrics. 
Formaldehyde is highly toxic by inhalation and is a strong irritant. Inhalation of its vapor from solution and skin contact with formaldehyde should be avoided. No toxicological profile was found for it at this time.

\subsubsection{Hexachlorobenzene}

Hexachlorobenzene (perchlorobenzene, $\mathrm{C}_{6} \mathrm{Cl}_{6}$ ) is a white-needled, crystalline, combustible solid, soluble in benzene and boiling alcohol but insoluble in water (Hawley 1977; National Research Council 1977). It is formed as a by-product during the manufacture of chemical solvents, chlorine-containing compounds, and pesticides. It is used in organic synthesis, fungriciries for seeds, and wood preservatives.

Hexachlorobenzene tends to remain as a solid in the environment. If it is released to the soil, half of it will still exist after 3 to 6 years; and half of what is released to lakes and groundwater will remain 30 to 300 days later. It is not clear how long particles of hexachlorobenzene will remain in the air (DHHS 1990f).

The health effects caused by breathing hexachlorobenzene or by getting it on the skin are not known. However, porphyria-induced skin disorders have been reported in humans following ingestion of bread prepared from grain containing hexachlorobenzene. And there is evidence that it is toxic to young, nursing children, who may be particularly susceptible when exposed through breast milk. Animal studies indicate that long-term ingestion can harm the liver, immune system, kidneys, and blood, can produce eruptions and pigmentations of the skin, and may lead to cancer of the liver and thyroid (DHHS 1990f).

\subsubsection{Nephthalene}

Naphthalene (tar camphor, $\mathrm{C}_{10} \mathrm{H}_{8}$ ) is a white, crystalline, volatile solid, with an odor characteristic of mothballs, soluble in benzene, absolute alcohol, and ether, but insoluble in water (DHHS 1990g; Hawley 1977). It is derived from boiling coal tar by crystallization and distillation and from petroleum fractions upon catalytic processing. It is used as an intermediate in chemicals manufacturing, moth repellent, fungicide, explosives, lubricants, synthetic resins, synthetic tanning, preservatives, solvents, textile chemicals, and scintillation counters. It is considered in the subclass of PAHs (Mann et al. 1991). (See Section 3.3.11 for a discussion of PAHs.)

Naphthalene is toxic primarily by inhalation but also by ingestion and skin absorption. Hemolytic anemia (a condition involving the breakdown of the red blood cells) is the primary health concern for humans exposed for either short or long periods of time. Other effects commonly found include nausea, vomiting, diarrhea, kidney damage, jaundice, and liver damage. Cataracts may also be caused by inhalation exposure. Neither cancer nor birth defects have been demonstrated (DHHS 1990g). 


\subsubsection{Phenol}

Phenol (carbolic acid, phenylic acid, benzophenol, hydroxybenzene, $\mathrm{C}_{6} \mathrm{H}_{5} \mathrm{OH}$ ) is a colorless or white, crystalline, combustible solid that turns pink or red if not perfectly pure or if illuminated; it absorbs water from the air and liquefies, producing a distinctive odor and a sharp burning taste. Phenol is soluble in alcohol, water, ether, chloroform, glycerol, carbon disulfide, petrolatum, fixed or volatile oils, and alkalies (DHHS 1989i; Hawley 1977). Most of the phenol in the United States is made by the oxidation of cumene, yielding acetone as a by-product. Other processes include sulfonation, chlorination of benzene, Raschig, and oxidation of benzene. It is used in phenolic plastics and resins, epoxy resins, caprolactam (for nylon and other man-made fibers), 2,4-D (2,4-dichlorophenoxyacetic acid), solvents for refining lubricating oils, adipic acid, salicylic acid, phenolphthalein, pentachlorophenol, acetophenetidine, picric acid, germicidal paints, pharmaceuticals (such as antiseptics, mouthwash, sore-throat lozenges and remedies, and wart removers), laboratory reagents, dyes and indicators, slimicides, and disinfectants.

Phenol is toxic by ingestion, inhalation, and skin absorption, and is a strong irritant to tissue. Repeated exposure to low levels of phenol in drinking water has been linked with diarrhea and mouth sores in humans; eating very large amounts has resulted in death. The effects on humans of breathing phenol in the air are unknown. Short-term exposure of animals to high levels of phenol in the air is irritating to the lungs and causes muscle tremors and loss of coordination; longer-term exposure results in paralysis and severe injury to the heart, kidneys, liver, and lungs, followed by death. Exposure to the skin causes blisters and burns on the exposed area and can result in death (DHHS 1989i).

The term "phenol" is also used to describe a class of aromatic organic compounds in which one or more hydroxy groups are attached directly to the benzene ring. Examples are phenol itself (benzophenol), the cresols, xylenols, resorcinol, and naphthols. Though technically alcohols, their properties are quite different. High-boiling phenols are mixtures containing predominantly meta-substituted alkyl phenols. They are used in phenolic resins, as fuel-oil sludge inhibitors, and as solvents and as rubber chemicals (Hawley 1977).

\subsubsection{Polycyclic Aromatic Hydrocarbons}

Polycyclic aromatic hydrocarbons (PAHs) are a group of organic chemicals that are formed during the incomplete burning of coal, oil, gas, garbage, or other organic substances. There is no known use for most of these chemicals, except for research purposes. However, a few of them are used in medicines and to make dyes, plastics, and pesticides. They are ubiquitous in the environment in air, water, and soil. There are more than $100 \mathrm{PAH}$ compounds. Although the health effects of the individual PAHs are not exactly alike, the following are considered as a representative group (DHHS 1990h):

- Acenaphthene.

- Acenaphthylene. 
- Anthracene.

- Benz(a)anthracene.

- Benzo(a)pyrene.

- Benzo(b)fluoranthene.

- Benzo(ghi)perylene.

- Benzo(k)fluoranthene.

- Chrysene.

- Dibenz(a,h)anthracene.

- Fluoranthene.

- Fluorene.

- Indeno(1,2,3-cd)pyrene.

- Phenanthrene.

- Pyrene.

As pure chemicals, PAHs generally exist as colorless, white, or pale yellow-green solids. Most do not occur alone in the environment; rather they are found as mixtures of two or more PAHs. They do not dissolve easily in water, but some readily evaporate into the air. They do not burn easily, and they will last for months to years.

PAHs may enter the body quickly and easily by inhalation, ingestion, and skin absorption. They migrate to the fatty tissues of the body and tend to be stored primarily in the kidneys, liver, and fat, with smaller amounts in the spleen, adrenal glands, and ovaries; most exit through the excretory system within a few days. Human exposure by breathing or skin contact for long periods of time may result in cancer. Animal studies indicate harmful reproductive and immune system effects, birth defects, and decreased body weight.

\subsubsection{2,3,7,8-Tetrachlorodibenzo-p-dioxin}

2,3,7,8-Tetrachlorodibenzo-p-dioxin (2,3,7,8-TCDD, TCDD), commonly referred to as dioxin, is a colorless solid with no distinguishable odor (DHHS 1987). Dioxin is a chlorinated hydrocarbon that occurs as an impurity in the manufacture of the herbicide 2,4,5-T (2,4,5-trichlorophenoxyacetic acid) and other herbicides and germicides. It can be removed by extraction with coconut charcoal. Its half-life in soil is about one year (Hawley 1977). 
Dioxin is toxic by ingestion, inhalation, and skin absorption. In humans, it causes chloracne, a severe skin lesion that usually occurs on the head and upper body; unlike common acne, chloracne is more disfiguring and often lasts for years after the initial exposure. There is evidence that dioxin causes liver damage, loss of appetite, weight loss, and digestive disorders in humans. Animal studies have indicated toxicity to the immune system, spontaneous abortions, malformations in offspring, weight loss resulting in death, and carcinogenicity (DHHS 1987).

\subsubsection{Toluene}

Toluene (methylbenzene, phenylmethane, $\mathrm{C}_{6} \mathrm{H}_{5} \mathrm{CH}_{3}$ ) is a clear, colorless liquid with a sweet, benzene-like odor, soluble in alcohol, benzene, and ether, insoluble in water (Hawley 1977). It is flammable - a dangerous fire risk. It is derived by catalytic reforming of petroleum, as a by-product of styrene production, or as a by-product of coke-oven operations (fractional distillation of coal tar) (DHHS 1989k). It is used in aviation gasoline and highoctane blending stock; benzene, phenol, and caprolactam; solvents for paints and coatings, gums, resins, most oils, rubber, and vinyl organosols; diluent and thinner in nitrocellulose lacquers; adhesive solvents in plastic toys and model airplanes; chemicals, dyes, medicines, and perfumes; polyurethane resins; explosives (trinitrotoluene [TNT]); and toluene sulfonates (detergents) (National Research Council 1977).

Toluene is toxic by ingestion, inhalation, and skin absorption. Information on acute human exposure to toluene suggests a narcotic effect at approximately $200 \mathrm{ppm}$. Irritation to the eyes and the upper respiratory tract may occur at $100 \mathrm{ppm}$. Industrial exposure for several years at a mean atmospheric toluene concentration of $125 \mathrm{ppm}$ has not produced any detectable change in blood characteristics or in liver function, although workers exposed to toluene at $100-1,100 \mathrm{ppm}$ from two weeks to five years have demonstrated evidence of mild red-cell decrease, enlarged liver, and increased mean corpuscular hemoglobin concentration. A critical literature search failed to confirm any clinical or laboratory evidence of altered liver function in workers exposed to $80-300 \mathrm{ppm}$ over many years (National Research Council 1977).

Short-term exposure affects the nervous system, producing light-headedness and euphoria at first, followed by fatigue, confusion, general weakness, dizziness, sleepiness, drunken-type actions, memory loss, nausea, loss of appetite, unconsciousness, and, in some cases, death because the person cannot breathe. These symptoms disappear when exposure is stopped. Long-term exposure has been linked with permanent brain damage that affects speech, vision, and hearing and that results in loss of muscle control, memory, and balance (DHHS 1989k).

\subsubsection{Trichloroethylene}

Trichloroethylene $\left(\mathrm{CHClCCl}_{2}\right)$ is a stable, low-boiling, colorless, photoreactive liquid with a chloroform-like odor, soluble in common organic solvents and slightly soluble in water 
(Hawley 1977). It is derived from tetrachloroethane by treatment with lime or alkali in the presence of water, or by thermal decomposition, followed by steam distillation. It is used in metal degreasing; extraction solvents for oils, fats, and waxes; solvent dyeing; dry cleaning; refrigerants and heat exchange liquids; fumigants; cleaning and drying electronic parts; diluents in paints and adhesives; textile processing; chemical intermediates; and aerospace operations (flushing liquid oxygen).

Trichloroethylene is toxic by inhalation, and it causes cancer in mice. Inhalation of trichloroethylene results in central nervous system depression, dizziness, headache, lack of coordination, sleepiness, facial numbness, and unconsciousness, as evidenced by its previous use as an anesthetic (DHHS 1988a; National Research Council 1977). Exposure also causes eye, nose, and throat irritation, which worsens after longer exposures. Animal studies have shown that inhalation or ingestion of high levels produces liver and kidney damage, effects on the immune system and blood, and cancer of the liver, kidney, and lung. Consumption of alcohol can produce heightened susceptibility to liver and kidney injury. 


\section{CHARACTERIZATION OF TRACE ELEMENTS IN U.S. COAL BY RANK AND REGION}

The United States has the world's largest recoverable coal reserves, estimated at 291 billion tons (GT). ${ }^{*}$ Anthracite and bituminous rank coals constitute $88 \%$ of this total. The former Soviet Union places second with 270 GT, followed by China (109 GT), Australia (72 GT), the former West Germany (65 GT), South Africa (64 GT), and Poland (47 GT). These seven countries account for over $918 \mathrm{GT}$, or $90 \%$ of the world's estimated recoverable reserves of coal (DOE 1989).

Thus, about $30 \%$ of the world's recoverable coal reserves resides in the United States. Total U.S. reserves have been divided by the USGS into seven geographical provinces Eastern, Interior, Gulf, Northern Great Plains (or Northern Plains), Rocky Mountain, Pacific Coast, and Alaskan. These provinces are further subdivided into regions and fields. If the coal reserves are divided roughly by rank, much of the bituminous coal and anthracite is in the East, and much of the lignite and subbituminous coal is in the South and West (Schobert 1987). The following sections characterize the trace elements in coal for the significant U.S. reserves by rank, region, and state.

This study was designed and executed specifically to identify and quantify those trace elements in U.S. coals likely to end up as air toxic emissions by assembling characterization data on various source coals (and their emission products). Thus, the study suggests a more systematic way to classify domestic utility coals with respect to their air toxic precursors, not just their expected $\mathrm{SO}_{2}$ emissions.

To that end, principal primary literature sources were examined regarding the presence and magnitude of the precursor trace elements of potential air toxic emissions from the combustion of coals of different types. These primary sources, in the order of their importance in this study, include the following:

- Swanson et al. (1976).

- Gluskoter et al. (1977).

- Zubovic et al. (1979, 1967, 1966, 1964, 1961, 1960); Zubovic $(1966 a, b)$.

- White et al. (1984).

- Swaine (1990).

- Wewerka et al. (1976).

${ }^{*} \mathrm{GT}=$ gigatons, where a ton $(\mathrm{T})$ is $2,000 \mathrm{lb}$. 
- Abernethy et al. (1969).

- O'Gorman and Walker (1972).

- Ruch et al. (1974).

- Spackman (1982).

\subsection{BITUMINOUS COAL}

\subsubsection{Appalachian Bituminous Coal}

The Eastern Province includes large deposits of bituminous coal and some anthracite. It stretches from the northeastern portion of Pennsylvania southwestward to northern Alabama. The Eastern Province is about $900 \mathrm{mi}$ long in a northeast to southwest direction, and almost $200 \mathrm{mi}$ wide at its broadest point. The coal deposits of particular interest include the anthracite field in northeastern Pennsylvania and the Appalachian Region, which begins in Pennsylvania and runs through West Virginia into Kentucky, and includes parts of southeastern Ohio and western Virginia.

The Appalachian Field is one of the greatest deposits of bituminous coal in the world. Much of this field is composed of a vertical stacking of about 50 separate coal seams, although 117 seams have been identified in West Virginia. Only about 10 of these seams are being mined. The greatest is the Pittsburgh Seam, which covers an elliptical area of roughly $20,000 \mathrm{mi}^{2}$. It lies in western Pennsylvania, southeastern Ohio, and northern West Virginia. About $5,000 \mathrm{mi}^{2}$ of the Pittsburgh Seam is being mined actively, where the seam ranges from 6 to $14 \mathrm{ft}$ thick.

When the coal was being deposited during the Carboniferous Period, this region was, at times, an extension of the Gulf of Mexico. At other times, it was cut off from the Gulf and existed as an inland sea. This change in environment while the coal was being deposited, from the saline water of the Gulf to the almost fresh water of an inland sea, has caused significant variability in the coal of the Appalachian Field. The deposition of plant debris over such a wide geographical region resulted in the plant material being buried nonuniformly throughout the region. Because coalification depends on the depth of burial, the coal seams in the Appalachian Field show some variability in properties due to this factor. Kentucky is the leading coal-producing state (Schobert 1987).

Data on U.S. Appalachian bituminous coals are tabulated by state for Pennsylvania, Ohio, West Virginia, Virginia, eastern Kentucky, and Tennessee. Typical (average) concentrations for each of the trace elements of HAP interest and calorific values are given in Table 9. Their elemental minima and maxima are given in Table 10. 


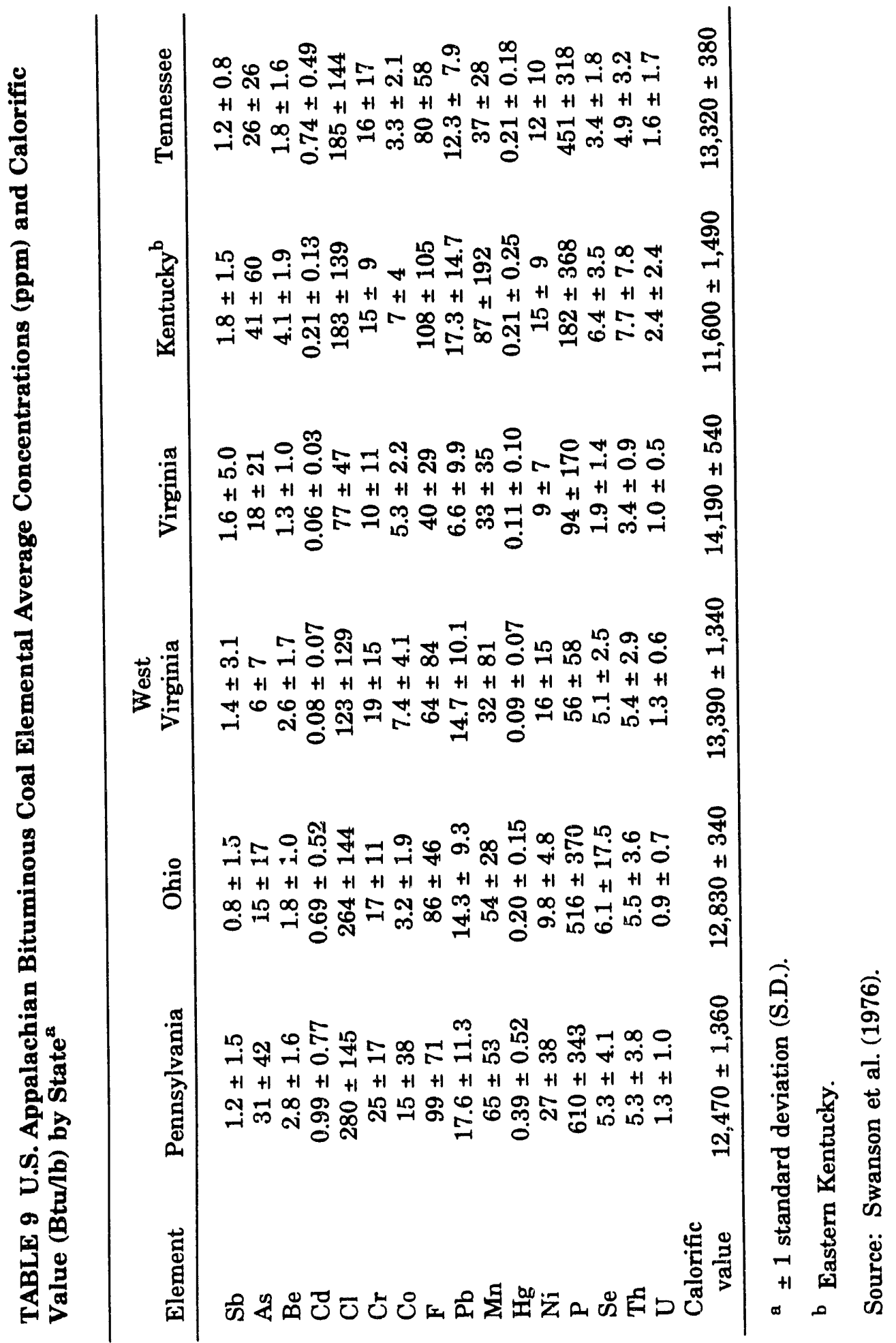




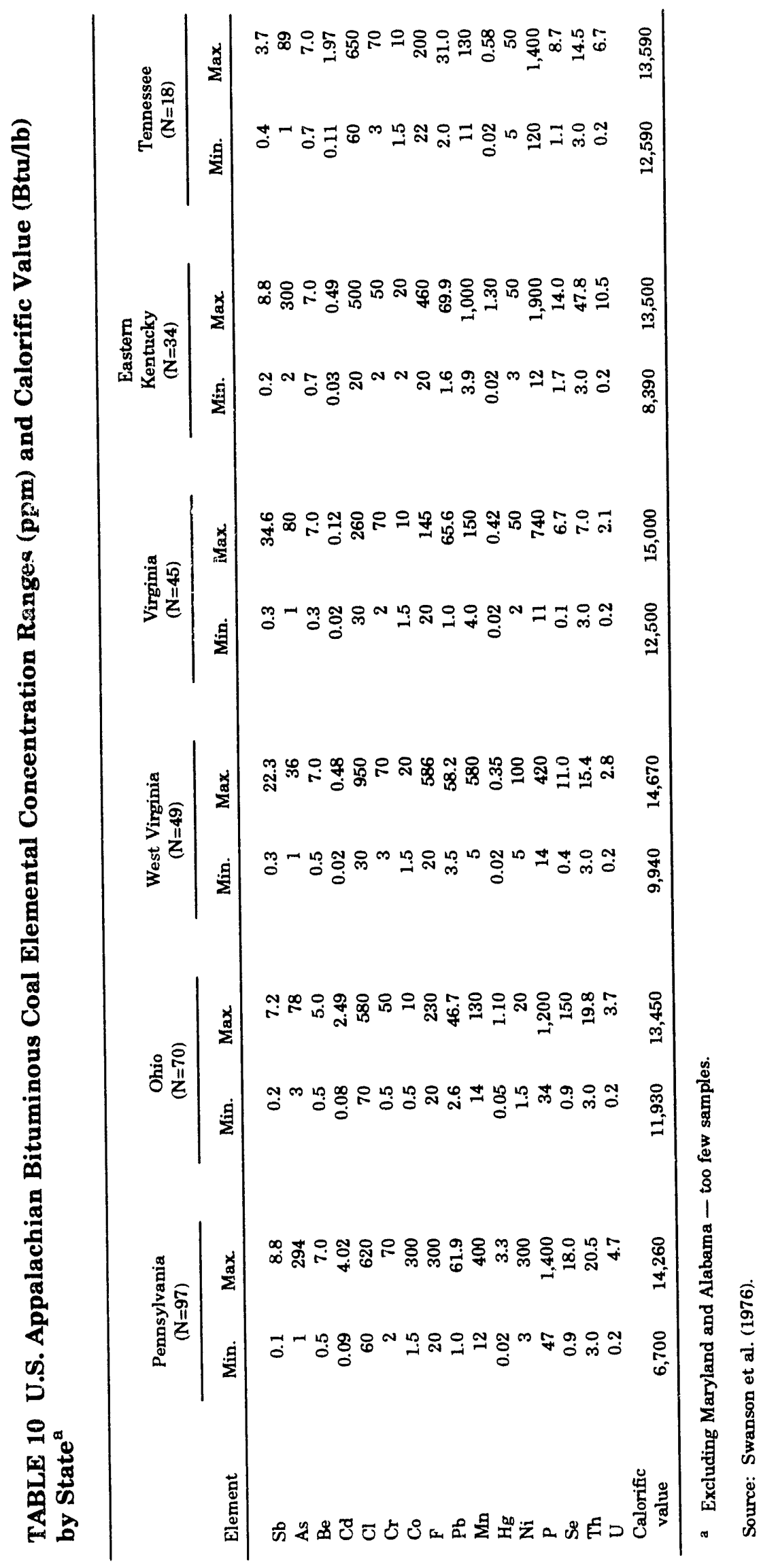


The data summarized here are from Swanson et al. (1976). Data characterizing Maryland and Alabama coals are not included here because their populations were considered nonrepresentative - there are too few samples with complete information in the source document; no data for $\mathrm{Rn}$ are available. The typical elemental concentrations are used to calculate projected emissions in Section 6.

The data summarized in Table 9 are corroborated by White et al. (1984) and lie within the range reported for the average concentrations \pm 1 standard deviation (S.D.) (Table 11), except for eastern Kentucky's Be (4.1 ppm) and Th (7.7 ppm).

Within the Appalachian Bituminous Region, Pennsylvanian coals exhibit the highest typical elemental concentrations (Table 9, in ppm) for $\mathrm{Cd}(0.99), \mathrm{Cl}$ (280), $\mathrm{Cr}$ (25), $\mathrm{Co}$ (15), $\mathrm{Pb}$ (17.6), $\mathrm{Hg}(0.39), \mathrm{Ni}(27)$, and $\mathrm{P}(610)$. Eastern Kentucky coals exhibit the highest typical concentrations for Sb (1.8), As (41), Be (4.1), F (108), Mn (87), Se (6.4), Th (7.7), and U (2.4).

TABLE 11 U.S. Elemental Average Coal Concentrations (ppm) by Rank ${ }^{\mathrm{a}}$

\begin{tabular}{ccccc}
\hline Element & $\begin{array}{c}\text { Anthracite } \\
(\mathrm{N}=52)\end{array}$ & $\begin{array}{c}\text { Bituminous } \\
(\mathrm{N}=3527)\end{array}$ & $\begin{array}{c}\text { Subbituminous } \\
(\mathrm{N}=640)\end{array}$ & $\begin{array}{c}\text { Lignite } \\
(\mathrm{N}=183)\end{array}$ \\
\hline $\mathrm{Sb}$ & $1.12 \pm 1.84$ & $1.22 \pm 2.27$ & $0.85 \pm 1.40$ & $1.01 \pm 2.23$ \\
$\mathrm{As}$ & $7.67 \pm 19.6$ & $20.3 \pm 41.8$ & $6.17 \pm 15.5$ & $22.8 \pm 138$ \\
$\mathrm{Be}$ & $1.32 \pm 0.85$ & $2.22 \pm 1.66$ & $1.30 \pm 1.77$ & $1.98 \pm 2.71$ \\
$\mathrm{Cd}$ & $0.22 \pm 0.30$ & $0.91 \pm 7.30$ & $0.38 \pm 0.47$ & $0.55 \pm 0.61$ \\
$\mathrm{Cl}$ & $\mathrm{NA}^{\mathrm{b}}$ & $\mathrm{NA}$ & $\mathrm{NA}$ & $\mathrm{NA}$ \\
$\mathrm{Cr}$ & $47.2 \pm 60.9$ & $20.5 \pm 27.5$ & $14.9 \pm 25.6$ & $13.5 \pm 18.2$ \\
$\mathrm{Co}$ & $7.27 \pm 9.42$ & $9.74 \pm 24.5$ & $6.63 \pm 18.3$ & $6.46 \pm 15.1$ \\
$\mathrm{~F}$ & $103 \pm 93.5$ & $88.5 \pm 103$ & $83.0 \pm 92.7$ & $191 \pm 360$ \\
$\mathrm{~Pb}$ & $7.32 \pm 6.92$ & $14.3 \pm 27.5$ & $6.35 \pm 5.47$ & $6.90 \pm 7.88$ \\
$\mathrm{Mn}$ & $100 \pm 200$ & $100 \pm 100$ & $100 \pm 200$ & $300 \pm 200$ \\
$\mathrm{Hg}$ & $0.23 \pm 0.27$ & $0.21 \pm 0.42$ & $0.10 \pm 0.11$ & $0.15 \pm 0.14$ \\
$\mathrm{Ni}$ & $28.5 \pm 32.0$ & $16.9 \pm 19.2$ & $7.02 \pm 8.44$ & $8.35 \pm 19.7$ \\
$\mathrm{P}$ & $700 \pm 1,000$ & $500 \pm 900$ & $1,300 \pm 1,400$ & $1,800 \pm 2,800$ \\
$\mathrm{Se}$ & $3.11 \pm 2.58$ & $3.39 \pm 4.00$ & $1.44 \pm 1.42$ & $2.70 \pm 3.67$ \\
$\mathrm{Th}$ & $6.09 \pm 2.92$ & $3.03 \pm 3.15$ & $5.13 \pm 4.64$ & $7.13 \pm 5.70$ \\
$\mathrm{U}$ & $1.94 \pm 3.38$ & $1.85 \pm 2.71$ & $2.13 \pm 3.84$ & $3.39 \pm 10.3$ \\
\hline a \pm 1 S.D. & & & & \\
b NA $=$ not available. & & &
\end{tabular}


The significant outlying maximum elemental concentrations by state (Table 10, in $\mathrm{ppm}$ ) are the following:

- Virginia - Sb (34.6);

- Eastern Kentucky - As (300), Mn (1,000), P (1,900), Th (47.8), and $\mathrm{U}(10.5)$;

- Pennsylvania - As (294), Cd (4.02), Co (300), Hg (3.3), and Ni (300);

- West Virginia - $\mathrm{Cl}(950)$ and F (586); and

- Ohio - Se (150).

\subsubsection{Interior Bituminous Coal}

Three regions make up the Interior Province - the Northern Region in Michigan; the Eastern Region in Illinois, southwestern Indiana, and western Kentucky; and the Western Region, comprising parts of Iowa, Missouri, Nebraska, Kansas, Arkansas, and Oklahoma.

The Eastern Region is the most important commercially. It occupies an area of roughly $50,000 \mathrm{mi}^{2}$. Although Illinois has more coal resources than any other state (coal underlies about two-thirds of its area), Kentucky leads the nation in coal production.

Interior Province coals were deposited primarily in shallow seas. They have not been exposed to the same degree of geological forces as the coals of the Eastern Province. Consequently, they have not matured to the same extent and tend to be of lower rank than Eastern Province coals. However, the seams are relatively horizontal and close to the surface, so mining tends to be easier (Schobert 1987).

Data on U.S. Interior bituminous coals are tabulated by state for Indiana, Iowa, Missouri, Oklahoma, Arkansas, Illinois, and western Kentucky. Typical (average) concentrations for each of the trace elements of HAP interest and calorific values are given in Table 12. Their elemental minima and maxima are given in Table 13.

The data summarized here are from Swanson et al. (1976), Gluskoter et al. (1977), and Zubovic et al. (1964). Data characterizing Michigan, Nebraska, and Kansas coals are not included here because their populations were considered nonrepresentative - there are too few samples with complete information in the source documents; no data for $\mathrm{Rn}$ are available. The typical elemental concentrations and the maximum concentrations are used to calculate projected emissions in Section 6. 


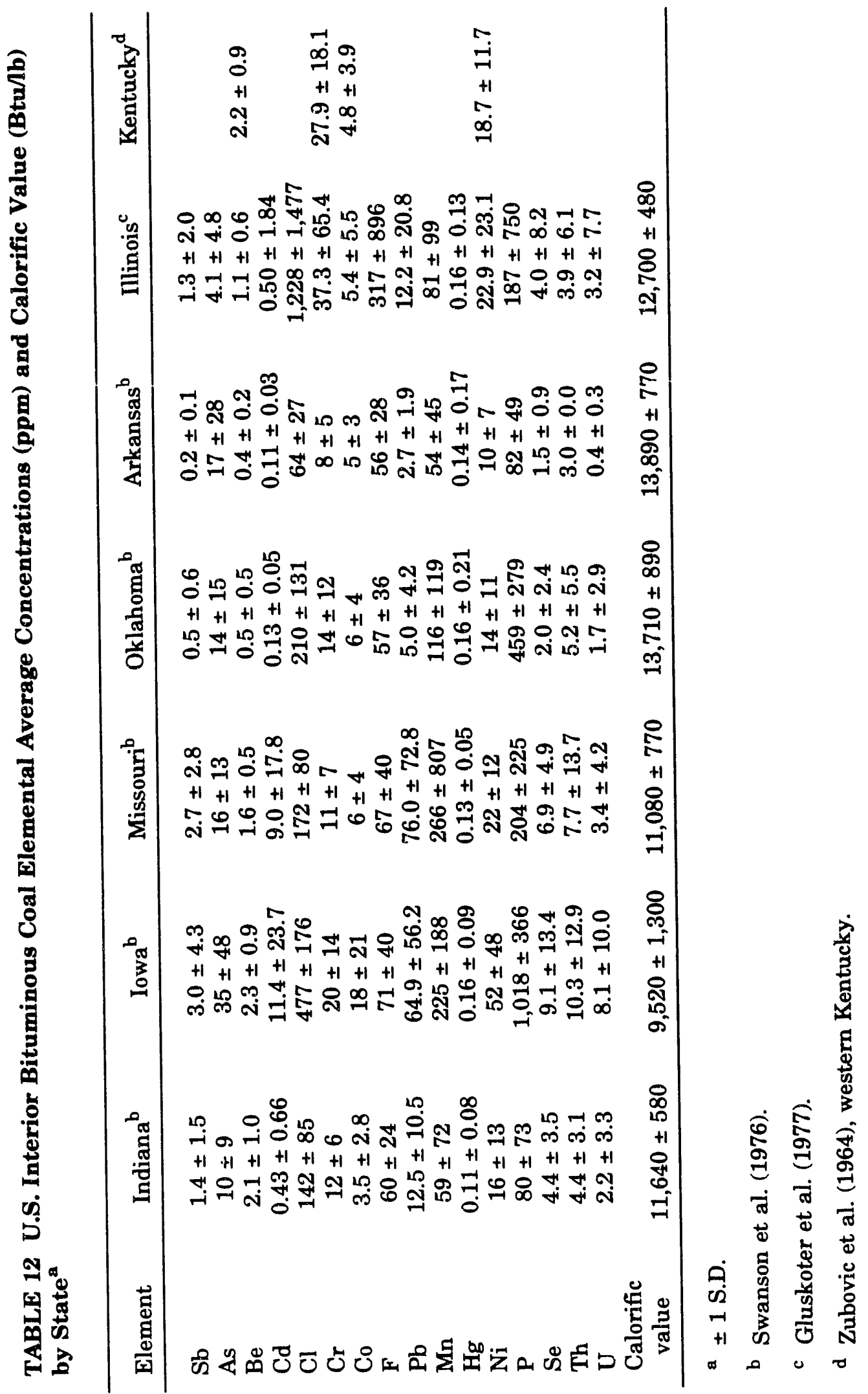


TABLE 13 U.S. Interior Bituminous Coal Elemental Concentration Ranges (ppm) and Calorific Value (Btu/lb) by State

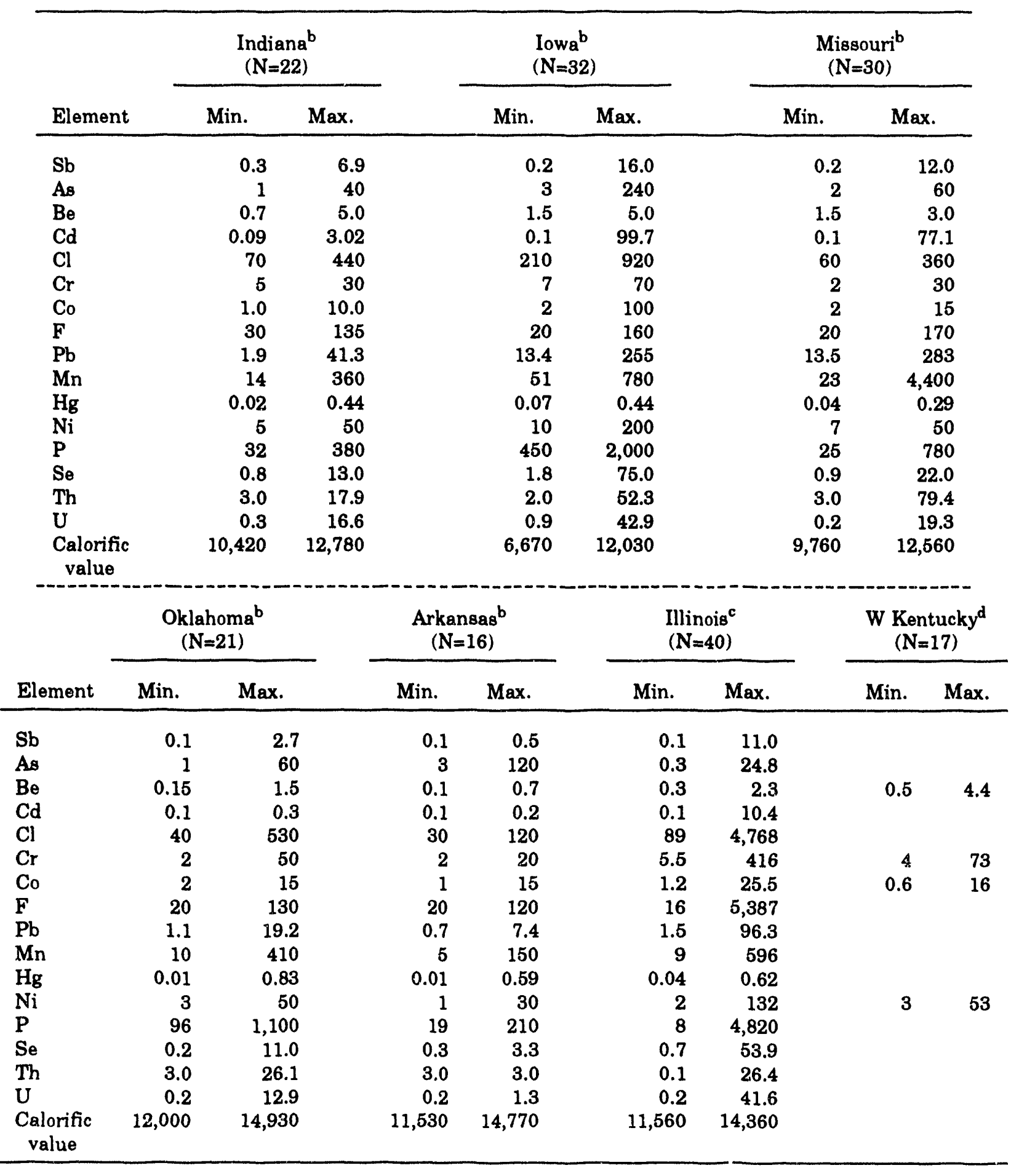

a Excluding Michigan, Nebraska, and Kansas - too few samples.

b Swanson et al. (1976).

c Gluskoter et al. (1977).

d Zubovic et al. (1964). 
The data summarized in Table 12 are corroborated by White et al. (1984) and lie within the range reported for the average concentrations \pm 1 S.D. (Table 11), except for Iowa's $\mathrm{Cd}$ (11.4 ppm), Pb (64.9 ppm), Mn (225 ppm), Ni (52 ppm), Se (9.1 ppm), Th (10.3 ppm), and $\mathrm{U}$ (8.1 ppm); Missouri's Cd (9.0 ppm), Pb (76.0 ppm), Mn (266 ppm), and Th (7.7 ppm); and Illinois's F (317 ppm).

Within the Interior Bituminous Region, Iowa coals exhibit the highest typical elemental concentrations (Table 12, in ppm) for $\mathrm{Sb}$ (3.0), As (35), Be (2.3), Cd (11.4), Co (18), $\mathrm{Ni}(52), \mathrm{P}(1,018)$, Se (9.1), Th (10.3), and U (8.1). Illinois coals exhibit the highest typical concentrations for $\mathrm{Cl}(1,228), \mathrm{Cr}$ (37.3), and $\mathrm{F}$ (317). Missouri coals exhibit the highest typical concentrations for $\mathrm{Pb}(76.0)$ and $\mathrm{Mn}$ (266). Mercury concentrations are relatively constant across the region $(0.11-0.16)$.

The significant outlying maximum elemental concentrations by state (Table 13 , in ppm) are the following:

- Iowa - Sb (16.0), As (240), Cd (99.7), Co (100), Ni (200), Se (75.0), and $\mathrm{U}(42.9)$;

- Illinois - $\mathrm{Cl}(4,768), \mathrm{Cr}(416), \mathrm{F}(5,387)$, and $\mathrm{P}(4,820)$;

- Missouri - Pb (283), Mn (4400), and Th (79.4); and

- Oklahoma - Hg (0.83).

\subsubsection{Rocky Mountain Bituminous Coal}

The Rocky Mountain Province contains the coal fields in the mountains running roughly north and south from New Mexico through Colorado, Utah, and Wyoming to Montana. Virtually every rank of coal can be found somewhere in the province. Part of the great variability in rank comes from the exposure of the coal deposits to varying degrees of thermal stress, for example, from localized magma intrusions and to varying degrees of tectonic stresses in mountain building. Hence, Rocky Mountain Province coals are higher in rank than Northern Plains coals of the same geological age because of increased thermal and tectonic stresses (Schobert 1987).

Data on U.S. Rocky Mountain bituminous coals are tabulared by coal field and state for Hanna, Wyoming; North Park, Colorado; Uinta, Utah; and Black Mesa, Arizona. Typical (average) concentrations for each of the trace elements of HAP interest and calorific values are given in Table 14. Their elemental minima and maxima are given in Table 15.

The data summarized here are from Swanson et al. (1976). Not included here are data characterizing Hams Fork and Green River, Wyoming; Boulder-Weld and Canon City, Colorado; and San Juan River, Raton Mesa, Carthage, and Jornada del Muerto, New Mexico coals because their populations were considered nonrepresentative - there are too few 
TABLE 14 U.S. Rocky Mountain Bituminous Coal Elemental Average Concentrations (ppm) and Calorific Value (Btu/lb) by State ${ }^{\mathrm{a}}$

\begin{tabular}{|c|c|c|c|c|}
\hline Element & $\begin{array}{l}\text { Hanna, } \\
\text { Wyoming }\end{array}$ & $\begin{array}{c}\text { North Park, } \\
\text { Colorado }\end{array}$ & $\begin{array}{l}\text { Uinta, } \\
\text { Utah }\end{array}$ & $\begin{array}{c}\text { Black Mesa, } \\
\text { Arizona }\end{array}$ \\
\hline Sb & $0.4 \pm 0.2$ & $0.2 \pm 0.2$ & $0.2 \pm 0.2$ & $0.3 \pm 0.1$ \\
\hline As & $3 \pm 2$ & $2 \pm 1$ & $1 \pm 1$ & $2 \pm 2$ \\
\hline $\mathrm{Be}$ & $0.4 \pm 0.5$ & $0.6 \pm 0.7$ & $0.4 \pm 0.3$ & $0.4 \pm 0.4$ \\
\hline $\mathrm{Cd}$ & $0.2 \pm 0.1$ & $0.1 \pm 0.2$ & $0.1 \pm 0.03$ & $0.09 \pm 0.04$ \\
\hline $\mathrm{Cl}$ & $115 \pm 42$ & $129 \pm 176$ & $96 \pm 44$ & $154 \pm 55$ \\
\hline $\mathrm{Cr}$ & $5 \pm 2$ & $11 \pm 16$ & $7 \pm 6$ & $3 \pm 2$ \\
\hline $\mathrm{Co}$ & $1.6 \pm 1.5$ & $2.4 \pm 2.5$ & $1.2 \pm 0.6$ & $1.2 \pm 0.7$ \\
\hline $\mathbf{F}$ & $70 \pm 33$ & $106 \pm 188$ & $61 \pm 54$ & $35 \pm 14$ \\
\hline $\mathrm{Pb}$ & $4.2 \pm 2.4$ & $4.9 \pm 4.7$ & $3.6 \pm 1.6$ & $2.4 \pm 1.1$ \\
\hline $\mathrm{Mn}$ & $41 \pm 33$ & $41 \pm 38$ & $18 \pm 33$ & $10 \pm 4$ \\
\hline $\mathrm{Hg}$ & $0.05 \pm 0.03$ & $0.05 \pm 0.04$ & $0.05 \pm 0.08$ & $0.03 \pm 0.01$ \\
\hline $\mathrm{Ni}$ & $5 \pm 3$ & $4 \pm 5$ & $2.8 \pm 2.0$ & $2.8 \pm 1.6$ \\
\hline $\mathbf{P}$ & $132 \pm 132$ & $201 \pm 142$ & $137 \pm 65$ & $333 \pm 120$ \\
\hline $\mathrm{Se}$ & $0.8 \pm 0.9$ & $1.2 \pm 1.2$ & $1.8 \pm 0.6$ & $1.6 \pm 0.3$ \\
\hline $\mathrm{Th}$ & $3.3 \pm 0.8$ & $6.7 \pm 7.3$ & $3.4 \pm 1.1$ & $3.0 \pm 0.2$ \\
\hline $\mathrm{U}$ & $1.5 \pm 0.5$ & $4.1 \pm 5.8$ & $0.9 \pm 0.7$ & $0.5 \pm 0.3$ \\
\hline \multirow{2}{*}{$\begin{array}{l}\text { Calorific } \\
\text { value }\end{array}$} & & & & $10890+630$ \\
\hline & $10,570 \pm 640$ & $10,020 \pm 1,230$ & $12,530 \pm 720$ & \\
\hline
\end{tabular}

Source: Swanson et al. (1976).

samples with complete information in the source document; no data for $\mathrm{Rn}$ are available. The typical elemental concentrations are used to calculate projected emissions in Section 6 .

The data summarized in Table 14 are corroborated by White et al. (1984) and lie within the range reported for the average concentrations \pm 1 S.D. (Table 11), except for Colorado's Th $(6.7 \mathrm{ppm})$. Indeed, trace eiemental concentratiuns for the Rocky Mountain bituminous coals are quite low relative to White et al.'s tabulation in Table 11.

Within the Rocky Mountain Bituminous Region, Wyoming coals exhibit the highest typical concentrations (Table 14, in ppm) for $\mathrm{Sb}(0.4)$, As (3), $\mathrm{Cd}(0.2)$, and $\mathrm{Mn}$ (41). Colorado coals exhibit the lighest typical elemental concentrations for $\mathrm{Be}(0.6), \mathrm{Cr}$ (11), Co (2.4), F (106), $\mathrm{Pb}$ (4.9), Mn (41), Th (6.7), and U (4.1). Utah coals exhibit the highest typical concentrations for Se (1.8), whereas Arizona coals exhibit the highest typical elemental concentrations for $\mathrm{Cl}$ (154) and $\mathrm{P}$ (333). Mercury (0.03-0.05) and $\mathrm{Ni}(3-5)$ concentrations are relatively constant across the region. 


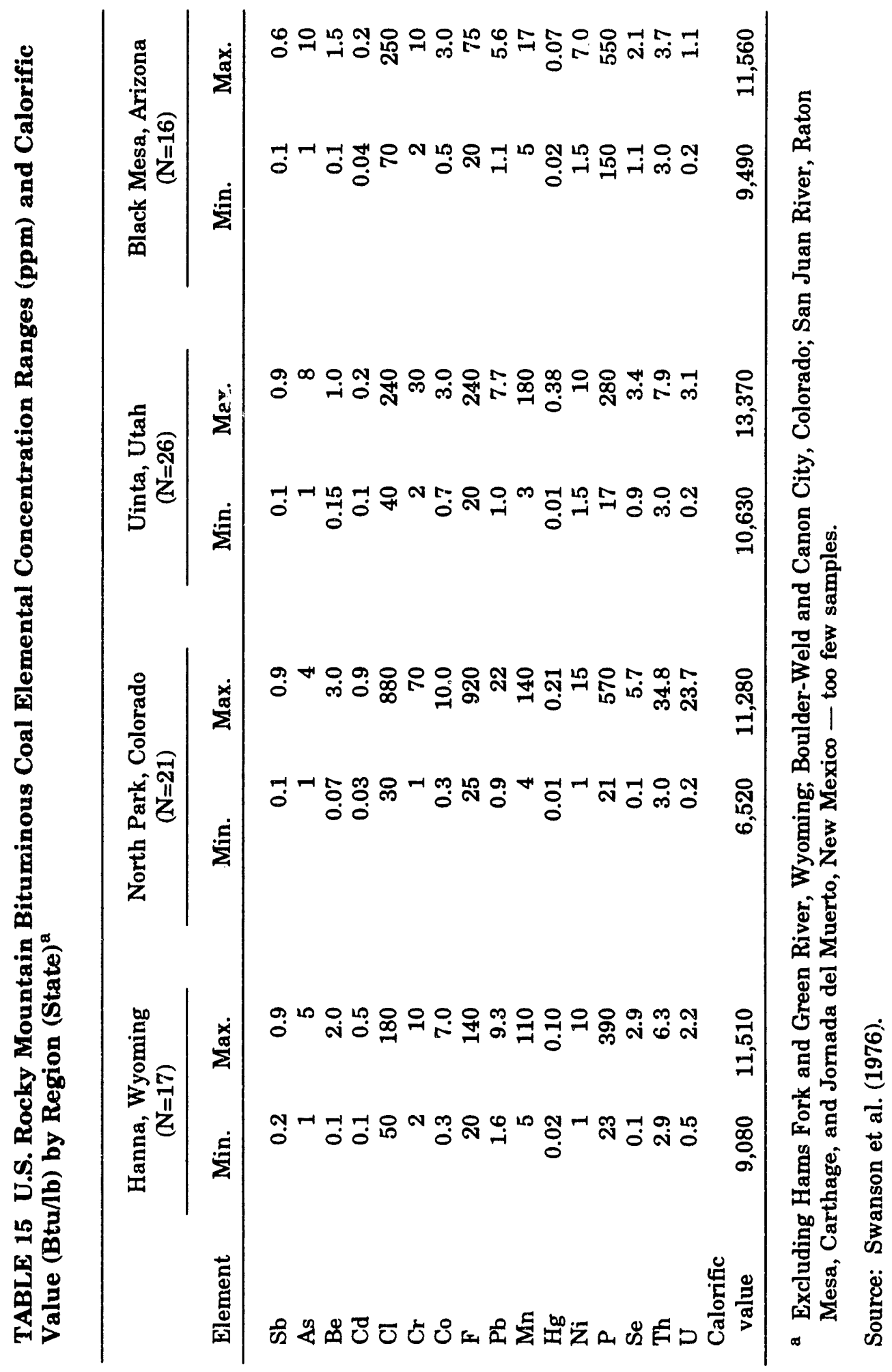


The significant outlying maximum elemental concentrations by state (Table 15 , in ppm) are the following:

- Colorado - Cl (880), Cr (70), F (920), Pb (22), Se (5.7), Th (34.8), and

$\mathrm{U}$ (23.7); and

- Utah - Mn (180) and $\mathrm{Hg}(0.38)$.

\subsection{LIGNITE}

The Gulf Province is one of two major lignite deposits in the United States; the other is the Northern Great Plains (Northern Plains) Province. The Gulf Province stretches from Alabama and Louisiana into Texas. It runs in a wide belt southwestward through Texas to the Rio Grande. Texas has become the nation's leading producer of lignite, and virtually all of the commercial development of Gulf Province lignites occurs in Texas. These lignites tend to be higher in sulfur and ash than the Northern Plains lignites because they were deposited in saline or brackish environments. The Northern Plains Province lies mostly in western North Dakota and eastern Montana, as well as in parts of northeastern Wyoming and northwestern South Dakota. The deposits of the province continue across the border into Canaua. The Fort Union Region is the largest deposit of lignite in the world.

Shipping lignites long distances is not practical because of their high moisture contents and low heating values. Electricity, on the other hand, is easy to "ship" - hence, "coal" by wire." To take advantage of the region's vast deposits of low-sulfur lignite, several large power plants were built along the Missouri River, north of Bismarck, North Dakota, in the 1970s. Since then, the province has become an exporter of electric power to the rest of the country (Schobert 1987).

Data on U.S. Alabama Gulf and North Dakota Northern Plains lignites are tabulated. Typical (average) concentrations for each of the trace elements of HAP interest and calorific values are given in Table 16. Their elemental minima and maxima are given in Table 17.

The data summarized here are from Swanson et al. (1976). Data characterizing Mississippi, Arkansas, and Texas Gulf lignites and Montana Northern Plains lignites are not included here because their populations were considered nonrepresentative - there are too few samples with complete information in the source document; no data for $\mathrm{Rn}$ are available. The typical elemental concentrations are used to calculate projected emissions in Section 6.

"Specifically lignite. 


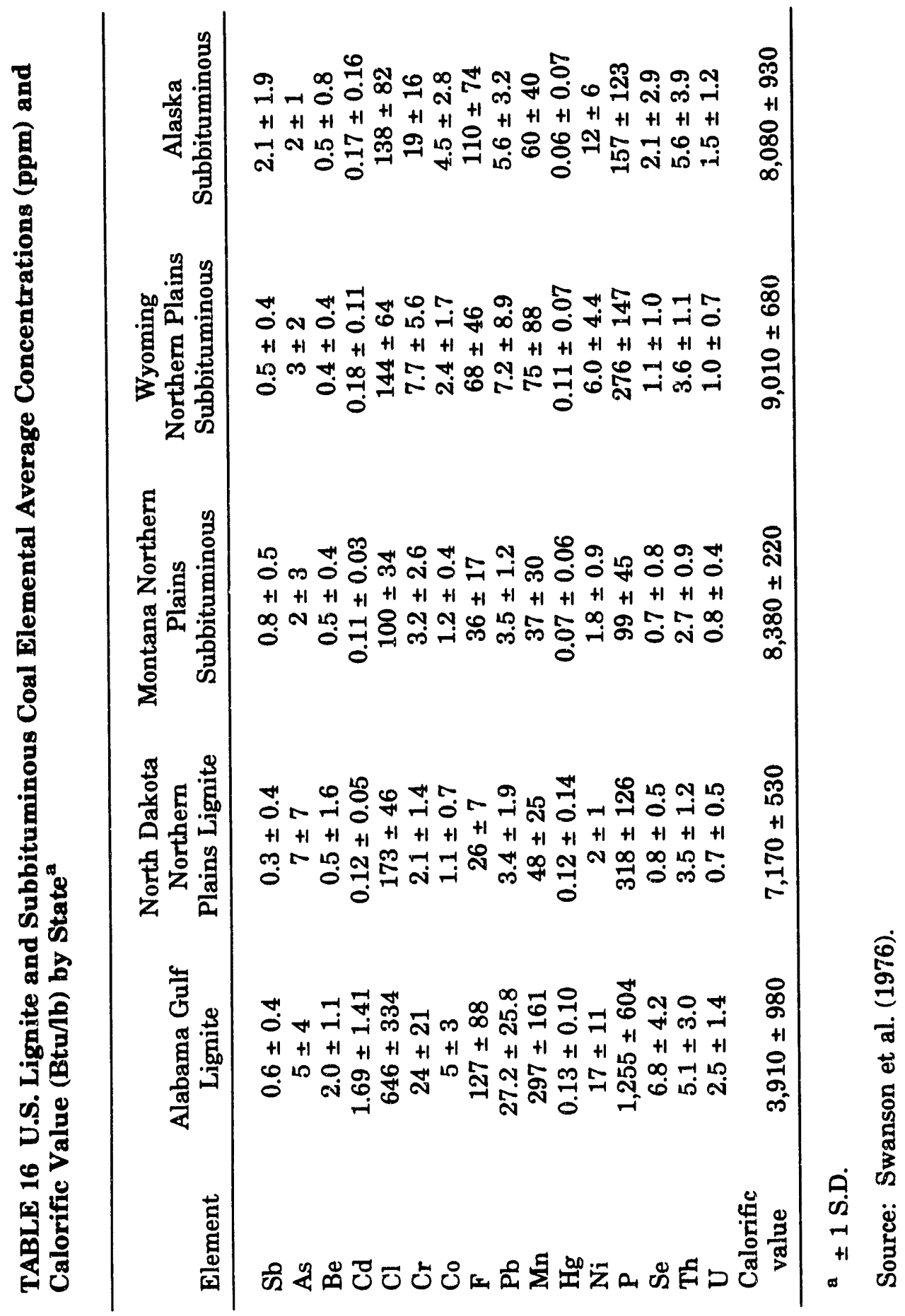


TABLE 17 U.S. Gulf and Northern Plains ${ }^{\mathrm{b}}$

Lignite Elemental Concentration Ranges (ppm) and Calorific Value (Btu/lb) by State

\begin{tabular}{|c|c|c|c|c|}
\hline \multirow[b]{2}{*}{ Element } & \multicolumn{2}{|c|}{$\begin{array}{c}\text { Alabama } \\
(N=19)\end{array}$} & \multicolumn{2}{|c|}{$\begin{array}{l}\text { North Dakota } \\
\quad(N=18)\end{array}$} \\
\hline & Min. & Max. & Min. & Max. \\
\hline $\mathrm{Sb}$ & 0.2 & 1.6 & 0.1 & 1.8 \\
\hline As & 1 & 16 & 1 & 30 \\
\hline $\mathrm{Be}$ & 0.7 & 5.0 & 0.2 & 7.0 \\
\hline $\mathrm{Cd}$ & 0.24 & 5.55 & 0.10 & 0.30 \\
\hline $\mathrm{Cl}$ & 170 & 1,400 & 110 & 260 \\
\hline $\mathrm{Cr}$ & 3 & 70 & 0.7 & 7.0 \\
\hline Co & 1 & 15 & 0.3 & 3.0 \\
\hline $\mathbf{F}$ & 24 & 340 & 20 & 40 \\
\hline $\mathrm{Pb}$ & 6.9 & 130 & 1.4 & 8.3 \\
\hline $\mathrm{Mn}$ & 91 & 690 & 21 & 120 \\
\hline $\mathrm{Hg}$ & 0.03 & 0.41 & 0.01 & 0.49 \\
\hline $\mathrm{Ni}$ & 3 & 50 & 0.7 & 5.0 \\
\hline $\mathbf{P}$ & 380 & 2,600 & 120 & 530 \\
\hline $\mathrm{Se}$ & 2.1 & 17.0 & 0.4 & 2.0 \\
\hline $\mathrm{Th}$ & 3.0 & 14.5 & 3.0 & 8.0 \\
\hline U & 0.5 & 5.7 & 0.2 & 2.6 \\
\hline $\begin{array}{l}\text { Calorific } \\
\text { value }\end{array}$ & 2,050 & 5,020 & 6,330 & 7,700 \\
\hline
\end{tabular}

a Excluding Mississippi and Arkansas - too few samples; Texas - no samples.

b Excluding Montana - no samples.

Source: Swanson et al. (1976).

The data summarized in Table 16 are corroborated by White et al. (1984) and lie within the range reported for the average concentrations \pm 1 S.D. (Table 11), except for Alabama's Cd (1.69 ppm), $\mathrm{Pb}(27.2 \mathrm{ppm})$, and $\mathrm{Se}(6.8 \mathrm{ppm})$. Indeed, trace elemental concentrations for these lignites are quite low relative to White et al.'s tabulation in Table 11.

The outlying maximum elemental concentrations by state (Table 17, in ppm) relative to White et al. (1984) (Table 11) are the following:

- Alabama - Cd (5.55), $\mathrm{rr}$ (70), Pb (130), Mn (690), Hg (0.41), Ni (50), Se (17.0), and Th (14.5); and

- North Dakota - Be (7.0) and Hg (0.49). 


\subsection{SUBBITUMINOUS COAL}

The most important Rocky Mountain coals are in the Powder River Basin. These coals are subbituminous, have low sulfur content, and occur in some of the thickest seams of the country. Because subbituminous coals have higher heating values and lower moisture contents than lignites, they are more suitable for long-distance transport. Power plants converting to low-sulfur coal in the 1970s caused a great expansion in coal production in the Powder River Basin. Coal from the region is now consumed in 20 states, with shipments predominantly to the Midwest (as far east as Ohio) and Texas (Schobert 1987).

Data on U.S. Montana and Wyoming Northern Plains and Alaskan subbituminous coals are tabulated. Typical (average) concentrations for each of the trace elements of HAP interest and calorific values are given in Table 16. Their elemental minima and maxima are given in Table 18.

TABLE 18 U.S. Northern Plains and Alaska Subbituminous Coal Elemental Concentration Ranges (ppm) and Calorific Value (Btu/lb) by State

\begin{tabular}{|c|c|c|c|c|c|c|}
\hline \multirow[b]{2}{*}{ Element } & \multicolumn{2}{|c|}{$\begin{array}{c}\text { Montana } \\
(\mathrm{N}=40)\end{array}$} & \multicolumn{2}{|c|}{$\begin{array}{c}\text { Wyoming } \\
(\mathrm{N}=35)\end{array}$} & \multicolumn{2}{|c|}{$\begin{array}{l}\text { Alaska } \\
(\mathrm{N}=13)\end{array}$} \\
\hline & Min. & Max. & Min. & Max. & Min. & Max. \\
\hline $\mathrm{Sb}$ & 0.2 & 2.5 & 0.2 & 2.1 & 0.5 & 8.1 \\
\hline As & 1 & 15 & 1 & 12 & 1 & 5 \\
\hline $\mathrm{Be}$ & 0.2 & 1.5 & 0.2 & 1.5 & 0.2 & 3.0 \\
\hline $\mathrm{Cd}$ & 0.1 & 0.2 & 0.1 & 0.4 & 0.1 & 0.6 \\
\hline $\mathrm{Cl}$ & 50 & 170 & 50 & 290 & 70 & 380 \\
\hline $\mathrm{Cr}$ & 1.0 & 15.0 & 2.0 & 30.0 & 7 & 70 \\
\hline Co & 0.5 & 2.0 & 0.7 & 7.0 & 1.5 & 10.0 \\
\hline$F$ & 20 & 80 & 30 & 255 & 35 & 335 \\
\hline $\mathrm{Pb}$ & 1.8 & 6.2 & 1.3 & 42.1 & 2.0 & 15.0 \\
\hline $\mathrm{Mn}$ & 9 & 140 & 9 & 370 & 11 & 130 \\
\hline $\mathrm{Hg}$ & 0.02 & 0.31 & 0.02 & 0.29 & 0.02 & 0.30 \\
\hline $\mathrm{Ni}$ & 0.7 & 5.0 & 1.5 & 20.0 & 5 & 30 \\
\hline $\mathrm{P}$ & 29 & 260 & 95 & 640 & 36 & 450 \\
\hline $\mathrm{Se}$ & 0.1 & 3.4 & 0.1 & 6.7 & 0.1 & 11.0 \\
\hline Th & 1.8 & 5.0 & 3.0 & 7.2 & 3.0 & 17.5 \\
\hline $\mathrm{U}$ & 0.2 & 1.7 & 0.2 & 2.9 & 0.5 & 5.2 \\
\hline $\begin{array}{l}\text { Calorific } \\
\text { value }\end{array}$ & 7,810 & 8,690 & 7,380 & 9,900 & 6,130 & 9,210 \\
\hline
\end{tabular}

Source: Swanson et al. (1976). 
The data summarized here are from Swanson et al. (1976). No data for Rn are available. The typical elemental concentrations are used to calculate projected emissions in Section 6.

All data summarized in Table 16 are corroborated by White et al. (1984) and lie within the range reported for the average concentrations \pm 1 S.D. (Table 11). Indeed, trace elemental concentrations for these subbituminous coals are quite low relative to White et al.'s tabulation in Table 11.

The outlying maximum elemental concentrations by state (Table 18 , in ppm) relative to White et al. (Table 11) are the following:

- Alaska - Sb (8.1), Cr (70), F (335), $\mathrm{Hg}(0.30)$, Se (11.0), and Th (17.5);

- Wyoming - F (255), $\mathrm{Pb}$ (42.1), $\mathrm{Mn}$ (370), $\mathrm{Hg}$ (0.29), $\mathrm{Ni}(20)$, and Se (6.7); and

- Montana - Hg (0.31) and Se (3.4).

\subsection{ANTHRACITE}

The anthracite field of the Eastern Province covers only $500 \mathrm{mi}^{2}$, yet the quality of coal is so high and the deposits are so rich that more than $20 \%$ of all the coal ever mined in the United States has come from this small part of Pennsylvania. One vein has been mined throughout the region - the Mammoth Seam, which averages $40 \mathrm{ft}$ thick.

Anthracite is found only in places where the sequence of rock and coal layers has been subjected to intense temperature and some increased pressure from rock folding. Because of the folding, the anthracite seams are generally tilted at large angles, sometimes as much as $80^{\circ}$ from the horizontal. This tilting complicates the mining process significantly. Today, U.S. anthracite contributes only a small fraction to the total coal production in the United States (Schobert 1987).

Data on U.S. Pennsylvanian anthracites are tabulated. Typical (average) concentrations for each of the trace elements of HAP interest and calorific values are given in Table 19. Their elemental minima and maxima are also given in Table 19.

The data summarized here sre from Swanson et al. (1976); no data for $\mathrm{Rn}$ are available. The typical elemental concentrations are used to calculate projected emissions in Section 6.

All the data summarized in Table 19 are corroborated by White et al. (1984) and lie within the range reported for the average concentrations \pm 1 S.D. (Table 11). Indeed, some of the trace elemental concentrations for these anthracites are quite low relative to White et al.'s tabulation in Table 11. 
TABLE 19 U.S. Pennsylvania Anthracite Elemental Average Concentrations, Ranges (ppm), and Calorific Value (Btu/lb)

\begin{tabular}{|c|c|c|c|}
\hline Element & $\begin{array}{l}\text { Average } \\
\pm 1 \text { S.D. }\end{array}$ & Min. & Max. \\
\hline $\mathrm{Sb}$ & $1.1 \pm 2.0$ & 0.1 & 12.5 \\
\hline As & $7 \pm 19$ & 1 & 140 \\
\hline $\mathrm{Be}$ & $1.4 \pm 0.9$ & 0.2 & 5.0 \\
\hline $\mathrm{Cd}$ & $0.23 \pm 0.43$ & 0.02 & 3.00 \\
\hline $\mathrm{Cl}$ & $142 \pm 152$ & 15 & 1,100 \\
\hline $\mathrm{Cr}$ & $22 \pm 13$ & 5 & 70 \\
\hline Co & $8 \pm 8.5$ & 0.3 & 50 \\
\hline $\mathbf{F}$ & $64 \pm 57$ & 20 & 290 \\
\hline $\mathrm{Pb}$ & $9.3 \pm 5.7$ & 1 & 24.2 \\
\hline $\mathrm{Mn}$ & $31 \pm 35$ & 4.8 & 213 \\
\hline $\mathrm{Hg}$ & $0.16 \pm 0.20$ & 0.03 & 1.25 \\
\hline $\mathrm{Ni}$ & $19 \pm 13$ & 3 & 70 \\
\hline $\mathbf{P}$ & $178 \pm 193$ & 15 & 950 \\
\hline Se & $3.5 \pm 2.6$ & 0.6 & 13.0 \\
\hline $\mathrm{Th}$ & $5.6 \pm 2.9$ & 2.8 & 14.4 \\
\hline $\mathbf{U}$ & $1.8 \pm 3.3$ & 0.3 & 25.2 \\
\hline $\begin{array}{l}\text { Calorific } \\
\text { value }\end{array}$ & 12,780 & 6,730 & 14,360 \\
\hline
\end{tabular}

Source: Swanson et al. (1976).

\subsection{TRACE ELEMENTAL HIGHLIGHTS BY COAL RANK AND REGION}

Table 20 compares and contrasts coal characterization data about the trace elements in U.S. coal by rank and region, from three different primary sources: Swanson et al. (1976), White et al. (1984), and Swaine (1990). Some generalizations include the following:

1. According to White et al. (1984) (Table 11), the highest mean value of various of the trace elements may serve to characterize the coals by rank:
a. Anthracite - $\mathrm{Cr}, \mathrm{Hg}$, and $\mathrm{Ni}$.
b. Bituminous - Sb, Be, Cd, $\mathrm{Co}, \mathrm{Pb}$, and $\mathrm{Se}$;
c. Subbituminous - none; and
d. Lignite - As, F, Mn, P, Th, and U. 
TABLE 20 Highlighted Highest and Lowest U.S. Coal Elemental Average Concentrations and Ranges by Region and Rank

\begin{tabular}{|c|c|c|c|c|c|c|}
\hline \multirow{3}{*}{$\frac{\text { Element }}{\mathrm{Sb}}$} & \multicolumn{6}{|c|}{ Highest Mean (ppm) } \\
\hline & \multicolumn{2}{|c|}{ by Region/Rank } & \multicolumn{2}{|c|}{ by Region ${ }^{b}$} & \multicolumn{2}{|c|}{ by Rank ${ }^{b}$} \\
\hline & 2.1 & Alaska/sub & 1.6 & Int & 1.2 & Bit \\
\hline As & 27 & App/bit & 22 & App & 23 & Lig \\
\hline $\mathrm{Be}$ & 3 & Int/bit & 2.3 & App-Int & 2.2 & Bit \\
\hline $\mathrm{Cd}$ & 7 & Int/bit & 5 & Int & 0.9 & Bit \\
\hline $\mathrm{Cl}$ & 646 & Gulf/lig & & - & & 一 \\
\hline $\mathrm{Cr}$ & 22 & Penn/an & 40 & Alaska & 47 & An \\
\hline Co & 8 & Penn/an & 19 & Alaska & 9.7 & Bit \\
\hline$F$ & 124 & Gulf/lig & 123 & RMtn & 191 & Lig \\
\hline $\mathrm{Pb}$ & 55 & Int/bit & 14 & Gulf-Alaska & 14 & Bit \\
\hline $\mathbf{M n}$ & 620 & App/bit & 300 & Gulf & 300 & Lig \\
\hline $\mathrm{Hg}$ & 0.24 & App/bit & 0.24 & App-Gulf & 0.23 & An \\
\hline $\mathrm{Ni}$ & 30 & Int/bit & 27 & Int & 28 & An \\
\hline$P$ & 1,255 & Gulf/lig & 2,200 & Alaska & 1,800 & Lig \\
\hline $\mathrm{Se}$ & 7 & Gulf/lig & 8 & Gulf & 3.4 & Bit \\
\hline Th & 8.3 & Gulf/lig & 9.0 & Gulf & 7.1 & Lig \\
\hline $\mathrm{U}$ & 3.3 & Int/bit & 3.1 & Gulf & 3.4 & Lig \\
\hline
\end{tabular}

Lowest Mean (ppm)

\begin{tabular}{|c|c|c|c|c|c|c|}
\hline \multirow{2}{*}{$\begin{array}{l}\text { Element } \\
\mathrm{Sb}\end{array}$} & \multirow[b]{2}{*}{0.6} & \multicolumn{2}{|l|}{ by Region/Rank ${ }^{\mathfrak{a}}$} & \multirow{2}{*}{$\frac{\text { by Region }^{\text {b }}}{\text { NPl }}$} & \multicolumn{2}{|c|}{ by $\operatorname{Rank}^{\mathrm{b}}$} \\
\hline & & NPl/ig-sub & 0.6 & & 0.8 & Sub \\
\hline As & 2 & RMtn/bit; Alaska/sub & 5 & Gulf-RMtn-Alaska & 6 & Sub \\
\hline $\mathrm{Be}$ & 0.5 & NP1/lig-sub; Alaska/sub & 0.8 & Alaska & 1.3 & An-sub \\
\hline $\mathrm{Cd}$ & 0.2 & NP1/ig-sub; Alaska/sub & 0.1 & App & 0.2 & An \\
\hline $\mathrm{Cl}$ & 120 & RMtn/bit & - & & - & \\
\hline $\mathrm{Cr}$ & 5 & NPl/lig-sub; RMtn/bit & 8 & $\mathrm{NPl}$ & 13 & Lig \\
\hline Co & 2 & NPl/ig-sub; RMtn/bit & 3 & NPl & 6.5 & Lig \\
\hline $\mathbf{F}$ & 45 & NPl/lig-sub & 68 & Gulf & 83 & Sub \\
\hline $\mathrm{Pb}$ & 5.3 & NPl/ig-sub & 6.4 & $\mathrm{NPl}$ & 6.4 & Sub \\
\hline $\mathrm{Mn}$ & 31 & Penn/an & - & & 100 & Bit \\
\hline $\mathrm{Hg}$ & 0.06 & RMtn/bit; Alaska/sub & 0.08 & Alaska & 0.10 & Sub \\
\hline $\mathrm{Ni}$ & 3 & NPl/ig-sub; RMtn/bit & 5.3 & $\mathrm{NPl}$ & 7 & Sub \\
\hline $\mathbf{P}$ & 157 & Alaska/sub & 300 & Gulf & 500 & Bit \\
\hline Se & 1.0 & NPl/lig-sub & 1 & NPl-Alaska & 1.4 & Sub \\
\hline Th & 2.7 & NPl/lig-sub & 3.0 & App & 3.0 & Bit \\
\hline $\mathrm{U}$ & 0.9 & NPl/lig-sub & 1.3 & Alaska & 1.8 & Bit \\
\hline
\end{tabular}


TABLE 20 (Cont.)

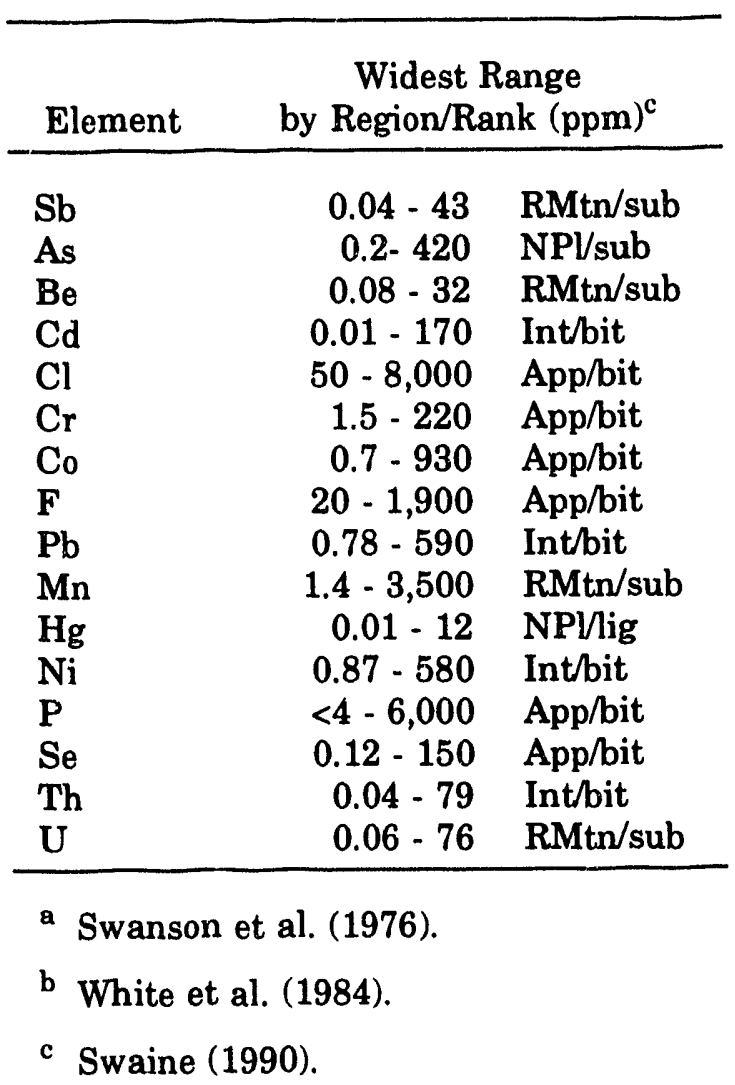

2. For each of the trace elements, the lowest mean value appears to be a nredominant characteristic of lower rank (lignite/subbituminous coals) andi'or western U.S. coals.

3. Accorsing to Swaine (1990), for each of the trace elements, the widest range of various of the trace elements may serve to characterize the coals by region and rank as follows:

a. Appalachian bituminous - $\mathrm{Cl}, \mathrm{Cr}, \mathrm{Co}, \mathrm{F}, \mathrm{P}$, and Se;

b. Interior bituminous - $\mathrm{Cd}, \mathrm{Pb}, \mathrm{Ni}$, and $\mathrm{Th}$;

c. Rocky Mountain subbituminous - Sb, Be, Mn, and U;

d. Northern Plains subbituminous - As; and

e. Northern Plains lignite - Hg.

Although Table 20 is an accurate and concise summary of the highlighted elemental concentrations by highest and lowest mean (typical) concentrations and by the widest range across regions and ranks, it may be difficult for the reader to digest. For this reason, selected 
elemental data are presented graphically and tabularly in Figures 1-3. Elements that may be emitted in the gaseous form - $\mathrm{Cl}, \mathrm{F}$, and $\mathrm{Hg}$ - and those elements that may be preferentially concentrated in the fly ash portion and then adsorbed significantly onto the smaller particulates - $\mathrm{Sb}, \mathrm{As}, \mathrm{Cd}, \mathrm{Cr}, \mathrm{Pb}, \mathrm{Ni}$, and $\mathrm{Se}$ - may be released to the atmosphere. Figure 1 indicates the typical concentrations by region and rank for the first group $-\mathrm{Cl}, \mathrm{F}$, and $\mathrm{Hg}$. Figure 2 shows typical concentrations by region and rank for the second group $\mathrm{Sb}, \mathrm{As}, \mathrm{Cd}, \mathrm{Cr}, \mathrm{Pb}, \mathrm{Ni}$, and $\mathrm{Se}$ (Swanson et al. 1976). Because $\mathrm{Hg}$ is of special interest relative to the ongoing EPA combined utility study mentioned in Chapter 1, Figure 3 represents typical $\mathrm{Hg}$ values by rank for each state where sufficient data exist. Table 5 summarizes and highlights the trace elements present in coal according to their postcombustion disposition.

\subsection{TRACE ELEMENTS IN U.S. COAL ASH}

Much information is available on trace elemental content in coal ash. Table 21 indicates the concentration ranges reported by Eschenroeder et al. (1985). Further consideration of this topic is outside the scope of the current work and is therefore left for another study and report. 


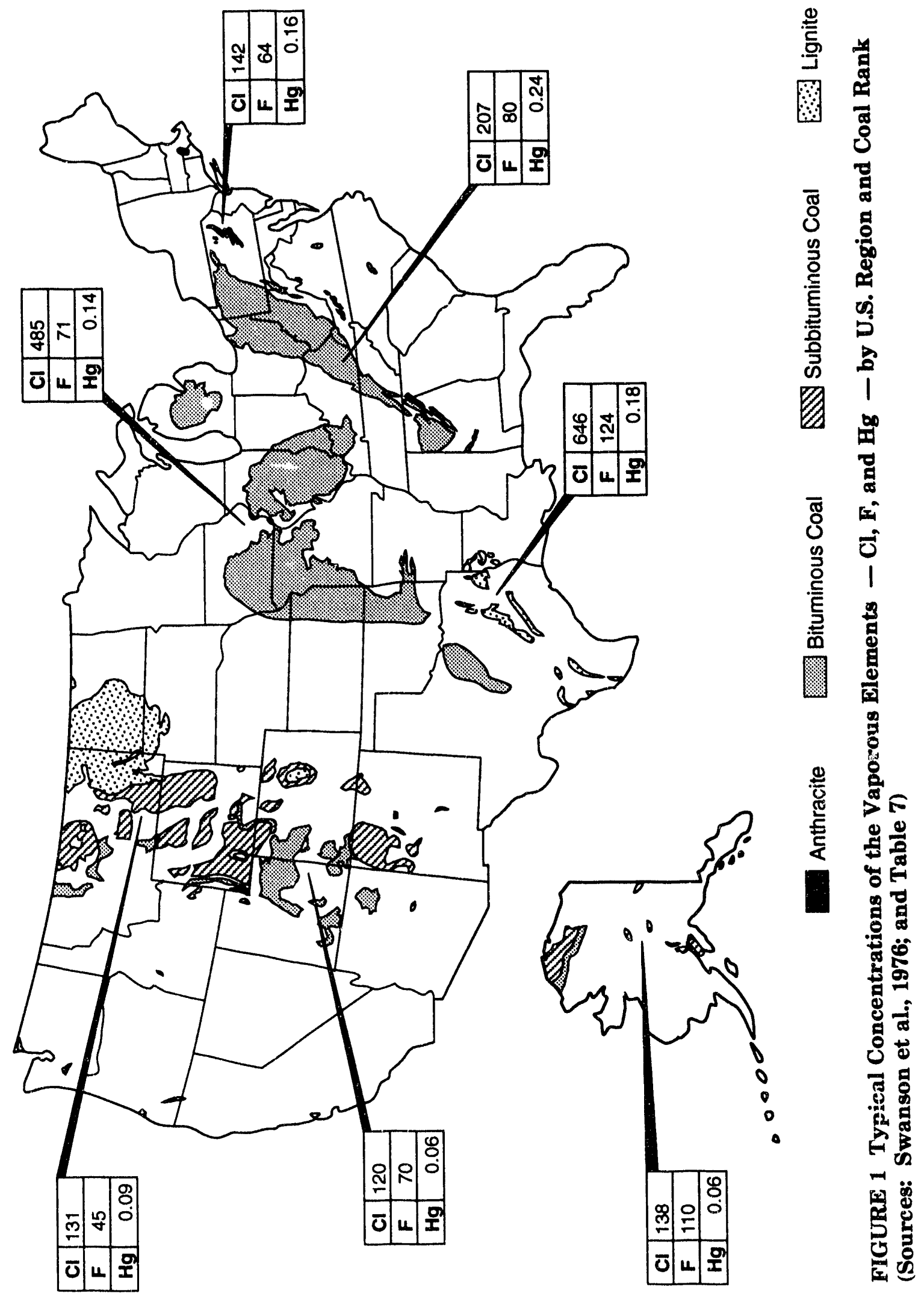




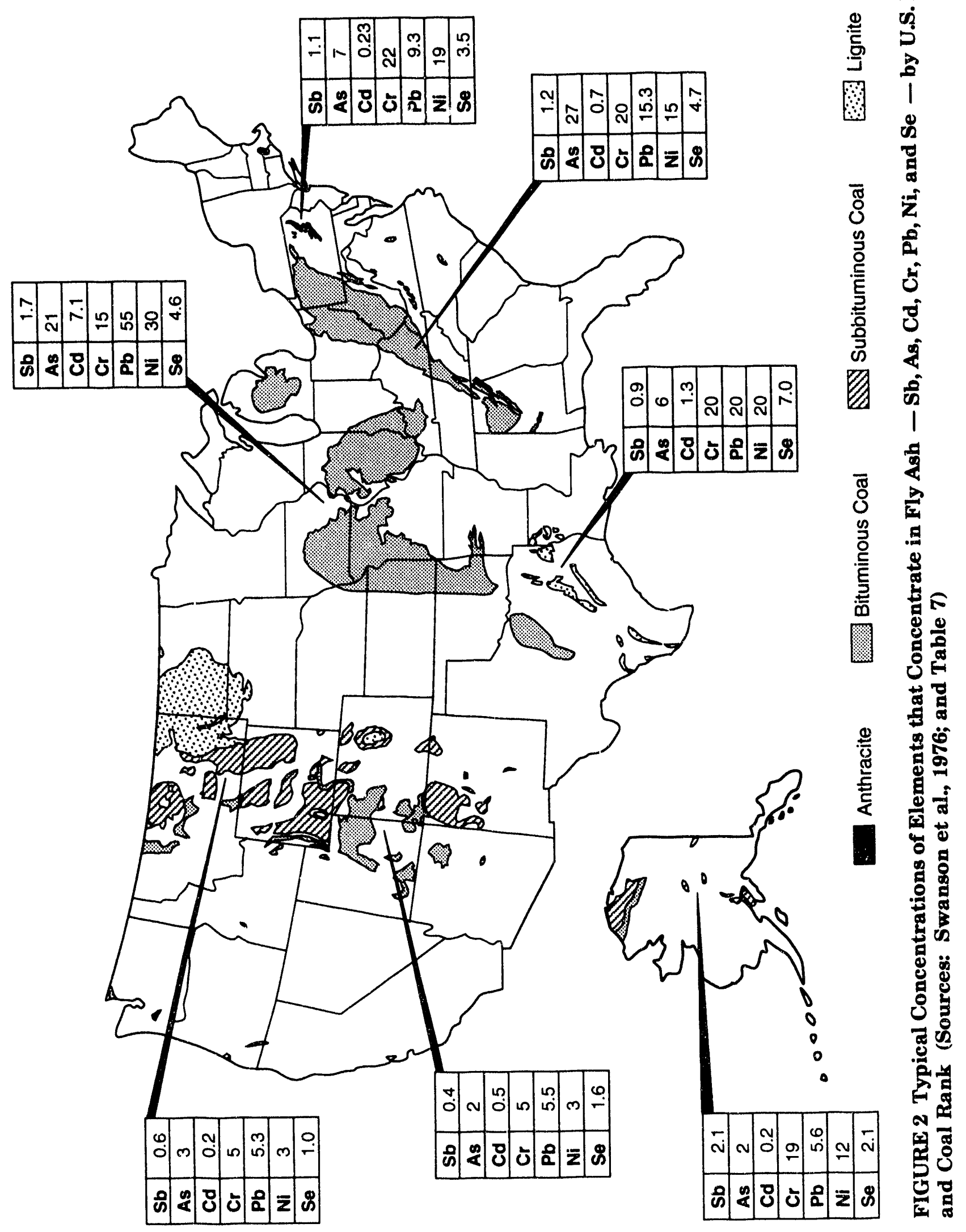




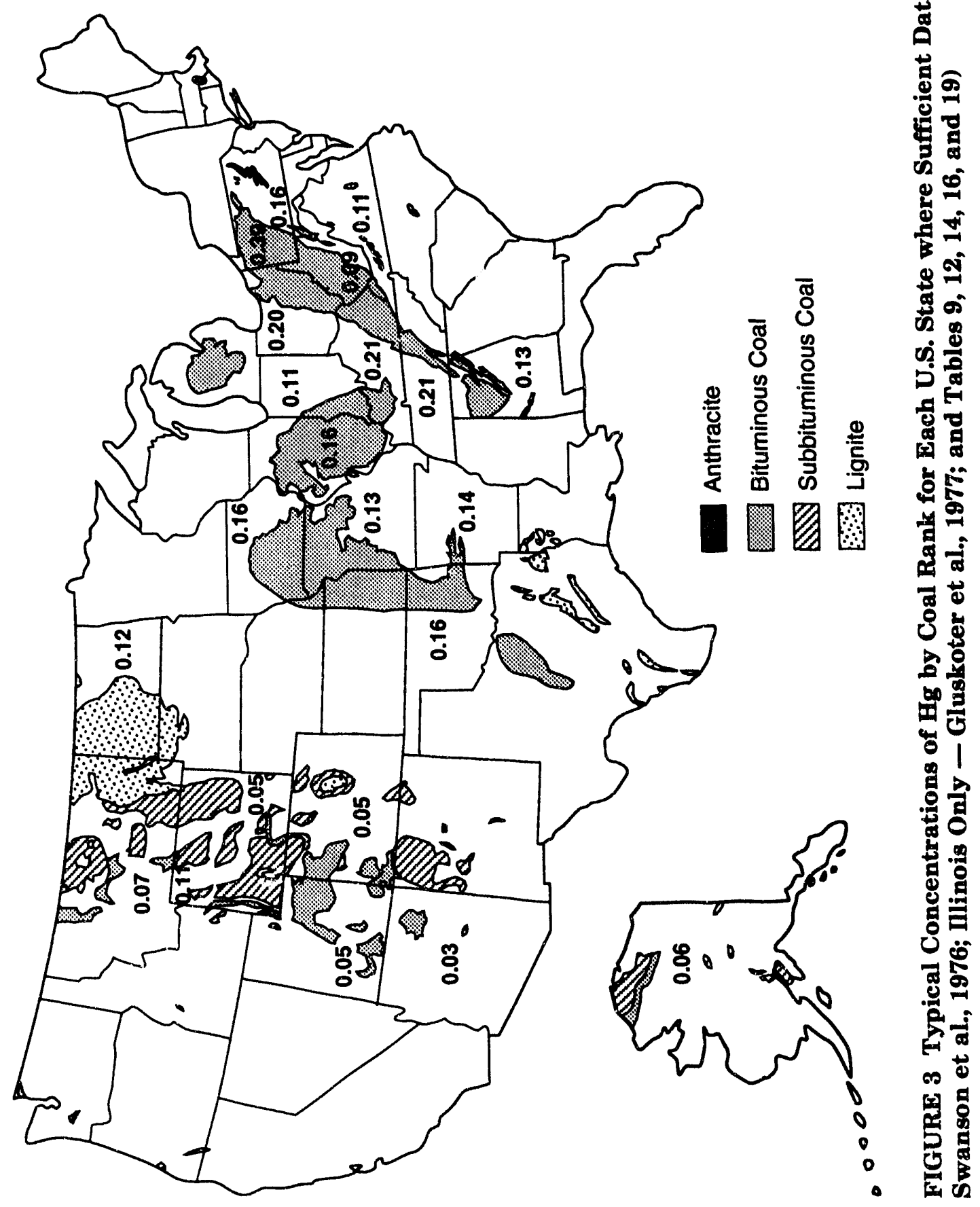


TARLE 21 Concentration Ranges of Trace Elements in U.S. Coal Ash (ppm)

\begin{tabular}{|c|c|c|c|c|c|c|}
\hline \multirow[b]{2}{*}{ Element } & \multicolumn{2}{|c|}{$\begin{array}{l}\text { Lignites and } \\
\text { Subbituminous }\end{array}$} & \multicolumn{2}{|c|}{ Bituminous } & \multicolumn{2}{|c|}{ Anthracites } \\
\hline & Min. & Max. & Min. & Max. & Min. & Max. \\
\hline $\mathrm{Sb}$ & $\mathrm{NA}^{\mathrm{a}}$ & NA & NA & NA & NA & NA \\
\hline As & 9 & 45 & 11 & 990 & NA & NA \\
\hline $\mathrm{Be}$ & 1 & 28 & 4 & 60 & 6 & 11 \\
\hline $\mathrm{Cd}$ & NA & NA & NA & NA & NA & NA \\
\hline $\mathrm{Cl}$ & 41 & 90 & 76 & 270 & NA & NA \\
\hline $\mathrm{Cr}$ & 11 & 140 & 36 & 490 & 210 & 395 \\
\hline Co & 11 & 310 & 10 & 440 & 10 & 165 \\
\hline $\mathrm{F}$ & 16 & 1,000 & 30 & 380 & NA & NA \\
\hline $\mathrm{Pb}$ & 20 & 165 & 23 & 1,500 & 41 & 120 \\
\hline $\mathbf{M}$ & 310 & 1,030 & 31 & 4,400 & 58 & 365 \\
\hline $\begin{array}{l}\text { n } \\
\mathrm{Hg}\end{array}$ & NA & NA & NA & NA & NA & NA \\
\hline $\mathrm{Ni}$ & 20 & 420 & 20 & 610 & 125 & 320 \\
\hline $\mathrm{P}$ & NA & NA & NA & NA & NA & NA \\
\hline $\mathrm{Se}$ & 5 & 16 & 10 & 37 & NA & NA \\
\hline Th & 21 & 43 & 26 & 54 & NA & NA \\
\hline $\mathrm{U}$ & NA & NA & NA & $\mathrm{NA}$ & NA & NA \\
\hline
\end{tabular}

a NA = not available.

Source: Eschenroeder et al. (1985). 


\section{EFFECTS OF COMBUSTION ON THE TRACE ELEMENTS IN COAL}

During coal combustion, trace elements are released from both the organic and mineral matter. Ash particles form as a result of complex processes involving fusion, volatilization, condensation, and coalescence. Most of the available information relates to pulverized-coal combustion. The distribution of trace elements in the combustion waste products is influenced by the type of boiler, operating conditions, and flue gas cleaning equipment, as well as the inherent concentrations in the coal.

Conventional air pollution control systems have the potential to remove many of the air toxic emissions from the flue gas generated from the combustion of coal. However, there is a lack of precise analytical data on the removal of those toxics across the various environmental control devices, such as electrostatic precipitators, baghouses, and wetlimestone scrubbers. Moreover, the relative concentrations of some of the toxic materials could also be increased as a result of using these technologies, in that residence times are sometimes increased with materials looping, or toxics could be formed with the addition of chemicals to the flue gas stream to increase particulate collection efficiency. For example, some of the more advanced $\mathrm{SO}_{2}$ and $\mathrm{NO}_{\mathbf{x}}$ mitigation technologies involve furnace injection of a sorbent and combustion modification. Thus, to date, little hard information exists on the effects these advanced technologies will have on the amounts of toxic substances formed in the combustion zone (Brown et al. 1991).

Estimates of the emissions of trace elements have been made, both measurements and calculations. A high percentage of $\mathrm{Sb}, \mathrm{Be}$, and $\mathrm{Se}$ emissions is from coal combustion, while $\mathrm{Ni}$ emissions are mainly from oil combustion. Smelters and secondary nonferrous metal plants release the largest amounts of $\mathrm{As}, \mathrm{Cd}$, and $\mathrm{Cu}$. Chromium and $\mathrm{Mn}$ are emitted largely from the manufacture of iron, steel, and ferroalloys and $\mathrm{Pb}$ from the combustion of gasoline (Pacyna et al. 1984).

Smith (1987) warns of the uncertainty of emission estimates, especially for the more volatile trace elements such as $\mathrm{Cd}, \mathrm{Hg}$, and Se. For example, the estimates in 1982 for total Cd emissions for West Germany were $328 \mathrm{t} / \mathrm{yr}^{*}$ according to Pacyna (1983) compared to only $23 \mathrm{t} / \mathrm{yr}$ by the Bundesministerium des Innern.

In particular, the difficulty of quantifying $\mathrm{Hg}$ emissions was outlined by Pacyna (1983), who estimated the amount adsorbed on particles in the total emissions for West Germany to be $4.7 \mathrm{t} / \mathrm{yr}$; of this amount, $0.7 \mathrm{t} / \mathrm{yr}$ was estimated to be derived from hard-coalfired emissions. This figure is far less than the $22 \mathrm{t} / \mathrm{yr}$ estimated for the gaseous form of $\mathrm{Hg}$ (Coenen 1985). Thus, it does not yet appear possible to make reliable estimates of the amounts of trace elements adsorbed on particles resulting from coal-fired combustion,

\footnotetext{
"The abbreviation $\mathrm{t} / \mathrm{yr}$ means metric tons per year; a metric ton (tonne) is $1,000 \mathrm{~kg}$. (A short
} ton $[2,000 \mathrm{lb}]$ is indicated by "T.") 
especially with respect to $\mathrm{Hg}$, despite the assertions of Diehl et al. (1972) and Swaine (1977) (Section 3.2.11).

Typical emission factors are difficult, if not impossible, to derive (Smith 1987). There is considerable uncertainty in the data available because of the wide variability of trace element concentrations in coal, variations in the design and operating parameters of boilers and control devices, and uncertainties in sampling and analysis.

\subsection{COMBUSTION TYPES AND TRACE ELEMENT EMISSIONS}

In small combustion units, stokers (including spreaders) of the chain and traveling grate types are used. The stokers operate within a temperature range of $900-1,400^{\circ} \mathrm{C}$. In this type of boiler, the ash is usually removed continuously by movement of the grate. Cyclone boilers burn crushed coal in a horizontal kiln into which a high-velocity stream of air is injected tangentially. Such injection creates a cyclonic flame pattern that centrifuges particles of coal to the walls where they burn. The resultant ash fuses to form slag (Smith 1987).

In larger boilers, pulverized-coal systems are used. Here, coal is dried and milled (normally smaller than $100 \mu \mathrm{m}$ ) before being transported by preheated air to the burners. Secondary air is generally introduced around or near the burner. Pulverized-coal firing yields more fly ash than bottom ash. The two types of combustion systems used with pulverized coal differ principally with respect to ash handling.

In the cyclone-fed slag tap boiler (or wet-bottom type), most of the fly ash is retained in the combustion chamber. The fused slag is periodically drained off and chilled, forming bottom slag. Corrosion problems and a lowered thermal efficiency due to loss of heat from ash melting have led to the decline of this type of boiler. Another disadvantage is the high operating temperature, which results in undesirably high $\mathrm{NO}_{\mathbf{x}}$ emissions. The operating temperature ranges from 1,450 to $1,650^{\circ} \mathrm{C}$, and the residence time of the ash is one to two hours, which favors evaporation of trace element compounds.

Blower-fed, pulverized-coal boilers with dry-bottom-ash removal are currently preferred. The temperature is about $200^{\circ} \mathrm{C}$ lower than that of the wet-bottom boiler, and the residence time of the ash in the high-temperature zone is reduced to a few seconds. Up to $90 \%$ of the coal ash is transported with the flue gas as fly ash through particulate controls, and the rest is removed as bottom ash.

The fluidized-bed combustion (FBC) type of boiler operates at a lower temperature, about $800-900^{\circ} \mathrm{C}$, at which the ash does not fuse. Combustion characteristics of FBCs operating at $800-900^{\circ} \mathrm{C}$ are different from those in pulverized-coal combustors operating at $1,600-1,700^{\circ} \mathrm{C}$. Thus, the distribution of trace elements in the waste products could be different from that resulting from conventional coal combustors. The emission of trace elements from FBC units is expected to be reduced because of less volatilization occurring at the lower combustion temperatures. This reduction could be partly offset by the longer 
residence time, thus allowing volatilization to occur. Preliminary results indicate that it may be possible to retain virtually all of the $\mathrm{Pb}$ and some of the $\mathrm{As}, \mathrm{Cl}, \mathrm{F}$, and $\mathrm{Hg}$ (Highley 1985).

Comparisons of fly ash produced in FBCs and pulverized-coal systems burning the same coal have shown that the two ashes have widely differing morphologies (Hobbs 1983; Gay and Von Rosenstiel 1982). The FBC particles were irregular in shape and not fused. Because of the porosity of the particles, FBC fly ash has more surface area, which probably improves the potential of FBC fly ash to adsorb vapor phase constituents. However, the enrichment characteristics of trace elements on the smaller particles were different (and lower, on the whole) in the FBC fly ash, except in the case of Pb. In FBC, the use of limestone or dolomite for $\mathrm{S}$ retention results in the addition of trace elements contained in the sorbent.

Preliminary tests have indicated that significant amounts of $\mathrm{Cl}$ and $\mathrm{F}$ may be absorbed. The $\mathrm{Cl}$ and $\mathrm{F}$ emissions may be reduced by lower temperatures as a result of greater retention in the ash.

Pressurized fluidized-bed combustion (PFBC) units were reported in 1975 to have significant proportions of gaseous $\mathrm{As}, \mathrm{Hg}, \mathrm{Pb}$, and $\mathrm{Se}$ in the flue gases. Also, a comparison with pulverized-coal combustion in 1977 showed that the elements $\mathrm{Sb}, \mathrm{As}, \mathrm{Be}, \mathrm{Cd}, \mathrm{Hg}$, and $\mathrm{Pb}$ were less enriched in the fly ash from the PFBC (Gill and Littlejohn 1980).

\subsection{CLASSIFICATION OF THE TRACE ELEMENTS - PARTITIONING}

The quantity and composition of the fine particles emitted upon coal combustion are highly dependent on the interactions between coal composition, combustor operating conditions, and furnace design. These interactions are not well defined. Physical processes related to plant design, turbulence during combustion, pollution control devices, temperature profiles, and other parameters all affect the distribution of trace elements.

During combustion, the coal particles undergo complex changes among which are the formation of char, agglomeration of melted inclusions, and vaporization of volatile elements. Finely dispersed elements, such as those bound on organic matter in the coal, vaporize to a larger extent than those found in micron-sized mineral inclusions, although the precise relationship between volatilization and organic affinity is not clearly understood. Vaporization is considered to be enhanced by high temperatures or by long residence times at reducing conditions. The volatile elements and those primarily associated with the organic fraction of the coal are $\mathrm{As}, \mathrm{Cl}, \mathrm{Hg}$, and $\mathrm{Se}$ (Smith 1987). However, most elements are removed in the solid residues.

Varying amounts of certain trace elements are present in the flue gases in hoth the solid state and in the gas phase. These trace elements may be released into the atmosphere with the flue gases. The amount of each element emitted depends on the concentration in the coal, the size and the type of boiler, the efficiency of the pollution control devices, and the distribution between the various phases. 
In actual material balance determinations, such as reported by Brown et al. (1991), material closure is not usually obtained for the elements $\mathrm{B}, \mathrm{Cd}, \mathrm{F}, \mathrm{Hg}$, and $\mathrm{P}$. In such determinations, some elements (e.g., $\mathrm{Sb}, \mathrm{As}, \mathrm{Cd}, \mathrm{Pb}$, and $\mathrm{Se}$ ) are usually enriched in the fly ash as they pass through the system from the furnace to the stack. Other elements (e.g., $\mathrm{Cr}$, $\mathrm{Co}$, and $\mathrm{Mn}$ ) show patterns of enrichment that vary from plant to plant. Most elements are found to reside in the silicate matrix and exhibit no enrichment patterns.

The volatile elements are assumed by some researchers to be emitted as vapors. These elements may include $\mathrm{As}, \mathrm{Cl}, \mathrm{F}, \mathrm{Hg}, \mathrm{S}$, and Se. In the flue gas, 4-73\% of the Se and $1-9 \%$ of the As in the coal are said to be released. Overall, the release of all radionuclides is measurably insignificant.

The classification of the elements by Klein et al. (1975) according to their partitioning in a pulverized-coal-fired (PCF) power plant has been cited by many authors and is largely confirmed (Smith 1987).

- Class I (nonvapcrization) elements exhibit low volatility, even at high temperatures $\left(1,200-1,600^{\circ} \mathrm{C}\right)$, and have no tendency to concentrate in or on the fly ash - Co, Mn, Th, U. These elements tend to distribute themselves equally in the bottom ash and fly ash (Szpunar et al. 1980). Phosphorus presumably can be categorized in this class until proven otherwise.

- Class II (vaporization-condensation) elements are vaporized but then recondense, tending to concentrate in or on the fines, and are depleted in the slag - $\mathrm{Sb}, \mathrm{As}, \mathrm{Cd}, \mathrm{Pb}$, and $\mathrm{Se}$. These elements preferentially concentrate in the fly ash fraction and exhibit pronounced concentration in the smaller fly ash particles (Szpunar et al. 1980).

- Class I/II (intermediate) elements exhibit both Class I and Class II behavior, showing no clear-cut preference - $\mathrm{Be}, \mathrm{Cr}$ (class II predominantly), and $\mathrm{Ni}$ (class II predominantly).

- Class III (vaporization-noncondensation) elements remain mostly in the gas phase and may be emitted from the stack - $\mathrm{Cl}, \mathrm{F}$, and $\mathrm{Hg}$.

The distribution of trace elements on the different particle sizes is not uniform, with the smaller particles exhibiting higher concentrations of several trace elements, particularly class II, than the larger sized particles. Enrichment on smaller particles has received much attention because these particles have higher atmospheric mobilities and greater potential toxicity. Enrichment is caused by the larger specific surface area (per unit weight) on small particles, which allows greater amounts of volatile elements to condense or be absorbed on 
the surface (Natusch 1978). This surface association is important in determining the toxicity of trace elements in coal fly ash for two reasons:

1. It increases the biological availability of trace elements on particles that might later contact body fluids and tissues such as the lungs, and

2. Conventional bulk analyses of particulates provide a poor measure of the actual concentrations of toxic trace elements to which the external environment is exposed.

Finally, solubility is also very important in determining trace element toxicity.

A variation on Klein's classification scheme regarding the behavior of trace elements during combustion has more recently been proposed by Clarke and Sloss (1992), who cite a wide group of researchers (Clarke 1991; Yokoyama et al. 1991; Meij 1989; Mojtahedi 1989; Smith 1987; Cherchar 1985; Conzemius et al. 1984; and Klein et al. 1975), as follows:

- Group 1 elements (Mn and Th) concentrate in the coarse residues or are equally partitioned between the coarse residues and the finer particulates. (Phosphorus, although not mentioned because it is considered a minor, not a trace, element, probably resides in this group.)

- Intermediate between Group 1 and Group 2 are $\mathrm{Be}, \mathrm{Co}, \mathrm{Cr}, \mathrm{Ni}$, and $\mathrm{U}$.

- Group 2 elements ( $\mathrm{Sb}, \mathrm{As}, \mathrm{Cd}$, and $\mathrm{Pb}$ ) volatilize in the combustor but condense downstream and are concentrated in the finer-grained particulates.

- Intermediate between Group 2 and Group 3 is Se.

- Group 3 volatile elements $(\mathrm{Cl}, \mathrm{F}$, and $\mathrm{Hg})$ are depleted in all solid phases.

Clarke and Sloss (1992) suggest that partitioning behavior varies for different combustion systems with different operating conditions, thus resulting in an overlapping classification scheme for the trace elements. Beryllium, $\mathrm{Co}, \mathrm{Cr}, \mathrm{Ni}$, and $\mathrm{U}$ have been grouped as intermediate between Group 1 and Group 2, and the relatively volatile element Se has been placed intermediate between Group 2 and Group 3. This overlap is not surprising since the divisions between groups are largely arbitrary and the conditions, especially the temperatures, may vary considerably.

In addition, toxic organics may be formed during combustion. These organics may then be released as gases or may be adsorbed onto fly ash particles.

In summary, differences ir combustion system, combustion temperature, excess air, and residence time (some of which are inherent in different methods of firing) add variables to the high variability of trace elements in coals and lead to a preferential enrichment of 
differing elements (and/or toxic organics) in or on the waste products. Differences in the origins of the coal - particularly in the chemical speciation of the elements - are especially important. Most trace elements are associated with the particulates. Volatile elements preferentially condense onto the surface of the smaller particles in the flue gas stream because of the greater surface area to volume ratio. Thus, the finest particles are enriched with certain Group 2 elements.

Typical individual emission factors by element or compound are difficult, if not impossible, to derive. There is considerable uncertainty in the data available because of the wide variability of trace element concentrations in coal, variations in the design and operating parameters of boilers and control devices (especially important in the formation of toxic organics), and the uncertainty in sampling and analysis. Thus, the distribution of trace elements (and toxic organics) in the combustion waste products is influenced by the type of boiler, operating conditions, and flue gas cleaning equipment, as well as their concentrations in the coal. 


\section{PROJECTED TRACE ELEMENT HAZARDOUS AIR POLLUTANT EMISSIONS}

Partitioning behavior upon coal combustion for the HAP trace elements has been presented in Section 5.2, which indicates there are three basic types. In summary, Group 1 includes those trace elements of low volatility, even at high combustion temperatures, that have no tendency to concentrate in or on the fly ash and that tend to concentrate in the coarse residues or distribute themselves equally between the coarse residues (bottom ash) and the finer particulates (fly ash) - Mn, Th, and, probably, P. Group 2 includes those trace elements that are vaporized but then recondense, preferentially concentrating in the fly ash fraction and exhibiting pronounced concentration in the smaller fly ash particles - Sb, As, $\mathrm{Cd}$, and $\mathrm{Pb}$. Group 3 includes those trace elements that are also vaporized but remain mostly in the gas phase and may be emitted from the stack in a gaseous form $-\mathrm{Cl}, \mathrm{F}$, and $\mathrm{Hg}$. Several trace elements are intermediate between these basic groups: $\mathrm{Be}, \mathrm{Co}, \mathrm{Cr}, \mathrm{Ni}$, and $\mathrm{U}$ (intermediate between Groups 1 and 2) and Se (intermediate between Groups 2 and 3).

Rigorous derivation of standard combustion emission factors is difficult because of the inherent nature of partitioning behavior, despite a variety of values having been reported by many researchers. Also, emission factors other than those actually measured may be only conjectural because partitioning behavior seems to depend on combustion system design, operating conditions, control devices, combustion temperature, amount of excess air, residence time, chemical form in the feed coal, and other variables.

Nevertheless, to guide the policymaker in judiciously monitoring and regulating HAPs, a single emission factor is assumed for each HAP trace element in this study. These assumed emission factors (Table 22) are based partly on research reported by Bignoli (1989) (for a hypothetical, new, modern, stringently regulated, coal-fired power plant) and partly on my assessment (as presented in Section 5.2) of the trace element partitioning literature since Natusch (1978). For reference, I have assumed a particulate capture efficiency of $99.8 \%$; compliance FGD, although unspecified as to type; and operation at a $70 \%$ capacity factor.

Although somewhat simplistic (given the cautions and behavior already discussed), this set of factors can be considered to represent the best conservative estimates available for emissions from a new, modern, environmentally regulated, coal-fired power plant. (Mercury [89\%], F [30\%], Se [14.4\%], and $\mathrm{Cl}$ [10\%] exhibit the highest emission factors.) These assumed, simplified emission factors permit the volume of trace element emissions from U.S. coals by region, state, and rank to be calculated.

Table 23 previews, summarizes, and highlights the projected quantity of total emissions for each region, state, and coal rank for which sufficient data are available

\footnotetext{
*What follows is a sample calculation format for trace element emissions from a hypothetical, 500-MWe, coal-fired power plant: (ppm trace element in the feed coal) $\times$ ( $\mathrm{T}$ coal presumed to be burned annually in the plant) $\times$ (assumed emission factor $)=(T$ trace element emitted annually $)$.
} 
(Appendix A, Tables A.1-A.7). Table 23 also indicates the quantity of dominant emissions of $\mathrm{Cl}, \mathrm{F}$, and to a lesser extent, $\mathrm{Mn}$, if the coal burned is assumed to have typical (average) concentrations for each of the HAP trace elements. If greater than typical concentrations of these HAP trace elements are present in the coal actually burned, the emissions of $\mathrm{As}, \mathrm{Co}, \mathrm{Pb}, \mathrm{Hg}$, and Se may also exceed the 10-TPY guideline and may need to be monitored.

\subsection{APPALACHIAN BITUMINOUS COAL}

From a regional viewpoint and on the basis of the typical characteristics of Appalachian bituminous coals, a new, modern, 500-MWe, coal-fired, electricity-generating power plant would probably exceed the 25-TPY CAAA limit. The plant may thus be su'jject to monitoring, if electric utilities are included for regulation after the currently mandated EPA studies. Calculations indicate that total annual emissions may reach $65 \mathrm{TPY}$, with probable $\mathrm{Cl}$ emissions of 22 TPY, F emissions of 26 TPY, and Mn emissions of 13 TPY (Appendix A, Table A.1). At their typical concentrations, other trace element HAPs do not appear to contribute significantly to emissions.

However, As, Co, and Se may also need to be monitored because each of their emissions levels could exceed 10 TPY if higher, although very atypical, concentrations of these elements were found in the actual feed coal burned. In a worst case scenario, nearly 1,570 TPY could be emitted.

\subsubsection{Pennsylvania}

Calculations indicate that projected total annual emissions from a new, modern, 500-MWe, coal-fired power plant burning Pennsylvanian bituminous coal are likely to reach 70 TPY, with probable Cl emissions of 31 TPY and F emissions of 33 TPY (Appendix A, Table A.1.1).
TABLE 22 Assumed Simplified Emission Factors for HAP Trace Elements from CoalFired Power Plants

\begin{tabular}{cr}
\hline & $\begin{array}{c}\% \\
\text { Element }\end{array}$ \\
\hline $\mathrm{Sb}$ & 2.4 \\
$\mathrm{As}$ & 2.8 \\
$\mathrm{Be}$ & 2.0 \\
$\mathrm{Cd}$ & 2.7 \\
$\mathrm{Cl}$ & 10.0 \\
$\mathrm{Cr}$ & 1.0 \\
$\mathrm{Co}$ & 1.2 \\
$\mathrm{~F}$ & 30.0 \\
$\mathrm{~Pb}$ & 1.8 \\
$\mathrm{Mn}$ & 2.0 \\
$\mathrm{Hg}$ & 89.0 \\
$\mathrm{Ni}$ & 0.4 \\
$\mathrm{P}$ & 0.1 \\
$\mathrm{Se}$ & 14.4 \\
$\mathrm{Th}$ & 0.4 \\
$\mathrm{U}$ & 1.2 \\
\hline On the basis of input \\
\hline fuel.
\end{tabular}



TABLE 23 Calculated Annual Significant Trace Element Emissions
from a New 500-MWe Power Plant ${ }^{\mathrm{a}}$ Firing U.S. Coal

\begin{tabular}{|c|c|c|c|}
\hline \multirow[b]{2}{*}{ Region - State - Coal Rank } & \multicolumn{2}{|c|}{ Typical Content (TPY) } & \multirow[b]{2}{*}{$\begin{array}{l}\text { Atypical } \\
\text { Content }^{b}\end{array}$} \\
\hline & $\begin{array}{l}\text { Calculated Total } \\
\text { Emissions }\end{array}$ & $\begin{array}{l}\text { Significant Elements } \\
\text { by Contribution }\end{array}$ & \\
\hline Appalachian Bituminous & 65 & $\mathrm{Cl}-22, \mathrm{~F}-26, \mathrm{Mn}-13$ & $\mathrm{As}, \mathrm{Co}, \mathrm{Se}$ \\
\hline Pennsylvania & 70 & $\mathrm{Cl}-31, \mathrm{~F}-33$ & -c \\
\hline Eastern Kentucky & 66 & $\mathrm{Cl}-22, \mathrm{~F}-39$ & As, $\mathrm{Mn}$ \\
\hline Ohio & 60 & $\mathrm{Cl}-29, \mathrm{~F}-28$ & $\mathrm{Se}$ \\
\hline Tennessee & 48 & $\mathrm{Cl}-19, \mathrm{~F}-25$ & - \\
\hline West Virginia & 35 & $\mathrm{Cl}-13, \mathrm{~F}-20$ & Mn \\
\hline Virginia & 21 & F -12 & $\mathrm{Cl}$ \\
\hline Interior Bituminous & 91 & $\mathrm{Cl}-58, \mathrm{~F}-26$ & $\mathrm{~Pb}, \mathrm{Mn}, \mathrm{Se}$ \\
\hline Illinois & 242 & $\mathrm{Cl}-134, \mathrm{~F}-104$ & $\mathrm{Mn}$ \\
\hline Iowa & 116 & $\mathrm{Cl} \cdot 70, \mathrm{~F}-31$ & $\mathrm{Mn}, \mathrm{Se}$ \\
\hline Missouri & 58 & $\mathrm{Cl}-22, \mathrm{~F}-25$ & Mn \\
\hline Oklahoma & 43 & $\mathrm{Cl}-21, \mathrm{~F}-17$ & - \\
\hline Indiana & 42 & $\mathrm{Cl}-17, \mathrm{~F}-21$ & - \\
\hline Arkansas & 25 & F -17 & $\mathrm{Cl}$ \\
\hline Rocky Mountain Bituminous & 46 & $\mathrm{Cl} \cdot 16, \mathrm{~F} \cdot 28$ & $\mathrm{Mn}$ \\
\hline Colorado & 64 & $\mathrm{Cl}-18, \mathrm{~F}-44$ & - \\
\hline Wyoming & 35 & $\mathrm{Cl}-15, \mathrm{~F}-18$ & - \\
\hline Arizona & 34 & $\mathrm{Cl}-20, \mathrm{~F}-13$ & - \\
\hline Utah & 32 & $\mathrm{Cl}-11, \mathrm{~F}-20$ & - \\
\hline $\begin{array}{l}\text { Northern Plains Lignite and } \\
\text { Subbituminous }\end{array}$ & 46 & $\mathrm{Cl}-22, \mathrm{~F}-22$ & As, $\mathrm{Mn}, \mathrm{Hg}$ \\
\hline North Dakota Lignite & 52 & $\mathrm{Cl} \cdot 34, \mathrm{~F} \cdot 15$ & - \\
\hline Wyoming Subbituminous & 57 & $\mathrm{Cl}-22, \mathrm{~F}-32$ & $\mathrm{Mn}$ \\
\hline Montana Subbituminous & 36 & $\mathrm{Cl}-17, \mathrm{~F}-18$ & - \\
\hline Gulf Lignite & 367 & $\begin{array}{c}\mathrm{Cl}-215, \mathrm{~F}-124, \\
\mathrm{Mn}-16\end{array}$ & - \\
\hline Alabama & 398 & $\begin{array}{c}\mathrm{Cl}-229, \mathrm{~F}-135 \\
\mathrm{Mn}-21\end{array}$ & - \\
\hline Alaskan Subbituminous & 84 & $\mathrm{Cl}-24, \mathrm{~F}-57$ & - \\
\hline Pennsylvanian Anthracite & 39 & $\mathrm{Cl}-15, \mathrm{~F}-21$ & - \\
\hline
\end{tabular}

a Hypothetical, new, modern, stringently regulated plant assuming particulate capture efficiency of $99.8 \%$; compliance FGD, although unspecified as to type; and operation at $70 \%$ capacity factor.

b Possible contributing element(s) if atypical concentration is present.

c The dash means no elements are significant. 
Projected emissions could more than double, thus reaching 160 TPY at the 2-S.D. level (representing 95\% of the sampled coal population) (Daniel and Terrell 1983). An exceedingly remote possibility could produce emissions exceeding 200 TPY in the worst possible scenario, that is, if the highest value of each HAP trace element reported were simultaneously present in the coal burned.

\subsubsection{Eastern Kentucky}

Calculations indicate that projected total annual emissions from a new, modern, 500-MWe, coal-fired power plant burning Eastern Kentucky bituminous coal are likely to exceed 66 TPY, with probable $\mathrm{Cl}$ emissions of 22 TPY and F emissions of 39 TPY (Appendix A, Table A.1.2).

Projected emissions may nearly triple, reaching 192 TPY at the 2-S.D. level, thereby bringing Mn into proposed noncompliance at 11 TPY. At the extremely atypical level, As may also need to be monitored because its emissions level could exceed 10 TPY if a higher, although atypical, concentration of this element were found in the actual feed coal burned. In that worst case, 268 TPY could be emitted.

\subsubsection{Ohio}

Calculations indicate that projected total annual emissions from a new, modern, 500-MWe, coal-fired power plant burning Ohio bituminous coal are likely to exceed 60 TPY, with probable $\mathrm{Cl}$ emissions of 29 TPY and F emissions of 28 TPY (Appendix A, Table A.1.3).

Projected emissions could more than double, exceeding 131 TPY at the 2-S.D. level. In addition, Se may also need to be monitored because its emissions level could exceed 10 TPY if a higher, although atypical, concentration of this element were found in the actual feed coal burned. In that worst case scenario, 170 TPY could be emitted.

\subsubsection{Tennessee}

Calculations indicate that projected total annual emissions from a new, modern, 500-MWe, coal-fired power plant burning Tennessee bituminous coal are likely to reach 48 TPY, with probable Cl emissions of 19 TPY and F emissions of 25 TPY (Appendix A, Table A.1.4).

At the 2-S.D. level, total emissions could reach 119 TPY. In the worst case scenario, 141 TPY could be emitted. 


\subsubsection{West Virginia}

Calculations indicate that projected total annual emissions from a new, modern, 500-MWe, coal-fired power plant burning West Virginia bituminous coal are likely to exceed 35 TPY, with probable $\mathrm{Cl}$ emissions of 13 TPY and F emissions of 20 TPY (Appendix A, Table A.1.5).

At the 2-S.D. level, total emissions could reach 120 TPY. In the worst case scenario, Mn could reach 12 TPY, and the total emissions could reach 300 TPY.

\subsubsection{Virginia}

Calculations indicate that projected total annual emissions from a new, modern, 500-MWe, coal-fired power plant burning Virginia bituminous coal are likely to exceed 21 TPY but should not exceed the 25-TPY level (Appendix A, Table A.1.6). However, F emissions at 12 TPY may trigger the 10-TPY level.

At the 2-S.D. level, with 52-TPY total emissions, $\mathrm{Cl}$ may reach 17 TPY and need to be monitored. In the worst case scenario, total emissions could exceed 78 TPY.

\subsection{INTERIOR BITUMINOUS COAL}

From a regional viewpoint and on the basis of the typical characteristics of Interior bituminous coals, a new, modern, 500-MWe, coal-fired power plant would probably exceed the 25-TPY CAAA limit and may thus be subject to monitoring. Calculations indicate that total annual emissions could exceed 91 TPY, with probable $\mathrm{Cl}$ emissions of 58 TPY and F emissions of 26 TPY (Appendix A, Table A.2). At their typical concentrations, other trace element HAPs do not appear to contribute significantly to emissions.

However, $\mathrm{Pb}, \mathrm{Mn}$, and Se may also need to be monitored because each of their emissions levels could exceed 10 TPY if higher, although atypical, concentrations of these elements were found in the actual feed coal burned. In a worst case scenario, more than 950 TPY could be emitted. (Data are not at hand to consider this category at the 2-S.D. level.)

\subsubsection{Illinois}

Calculations indicate that projected total annual emissions from a new, modern, $500-\mathrm{MWe}$, coal-fired power plant burning Illinois bituminous coal are likely to reach 242 TPY (the largest projected total emissions at typical trace element concentrations for bituminous coals), with probable $\mathrm{Cl}$ emissions of 134 TPY and F emissions of 104 TPY (Appendix A, Table A.2.1). 
At the 2-S.D. level, total emissions could more than quadruple, exceeding 1,160 TPY. Also, in the worst case scenario, Mn may need to be monitored because its emissions level could equal 13 TPY if a higher, although atypical, concentration of this element were found in the actual feed coal burned. In that worst case scenario, more than 2,320 TPY could be emitted.

\subsubsection{Iowa}

Calculations indicate that projected total annual emissions from a new, modern, 500-MWe, coal-fired power plant burning Iowa bituminous coal are likely to reach 116 TPY, with probable $\mathrm{Cl}$ emissions of 70 TPY and F emissions of 31 TPY (Appendix A, Table A.2.2).

At the 2-S.D. level, total emissions could double, reaching 231 TPY, with Mn exceeding 17 TPY. Also, Se may need to be monitored because its emissions level (16 TPY) could exceed 10 TPY if a higher, although atypical, concentration of this element were found in the actual feed coal burned. In that worst case scenario, 272 TPY could be emitted.

\subsubsection{Missouri}

Calculations indicate that projected total annual emissions from a new, modern, 500-MWe, coal-fired power plant burning Missouri bituminous coal are likely to exceed 58 TPY, with probable $\mathrm{Cl}$ emissions of 22 TPY and F emissions of 25 TPY (Appendix A, Table A.2.3).

At the 2-S.D. level, where total emissions could exceed 157 TPY, Mn could reach 47 TPY. In the worst case scenario, more than 235 TPY could be emitted.

\subsubsection{Oklahoma}

Calculations indicate that projected total annual emissions from a new, modem, 500-MWe, coal-fired power plant burning Oklahoma bituminous coal are likely to reach 43 TPY, with probable $\mathrm{Cl}$ emissions of 21 TPY and F emissions of 17 TPY (Appendix A, Table A.2.4).

At the 2-S.D. level, total emissions could more than double to 99 TPY. In the worst case scenario, more than 108 TPY could be emitted.

\subsubsection{Indiana}

Calculations indicate that projected total annual emissions from a new, modern, 500-MWe, coal-fired power plant burning Indiana bituminous coal are likely to reach 42 TPY, with probable $\mathrm{Cl}$ emissions of 17 TPY and F emissions of 21 TPY (Appendix A, Table A.2.5). 
At the 2-S.D. level, total emissions could more than double to 86 TPY. In the worst case scenario, more than 116 TPY could be emitted.

\subsubsection{Arkansas}

Calculations indicate that projected total annual emissions from a new, modern, 500-MWe, coal-fired power plant burning Arkansas bituminous coal are likely to exceed 25 TPY, with probable F emissions of 17 TPY (Appendix A, Table A.2.6).

At the 2-S.D. level, where total emissions could more than double to 52 TPY, Cl could reach 12 TPY. In the worst case scenario, 56 TPY could be emitted.

\subsection{ROCKY MOUNTAIN BITUMINOUS COAL}

From a regional viewpoint and on the basis of the typical characteristics of Rocky Mountain bituminous coals, a new, modern, 500-MWe, coal-fired power plant would probably exceed the 25-TPY CAAA limit and may thus be subject to monitoring. Calculations indicate that total annual emissions could reach 46 TPY, with probable $\mathrm{Cl}$ emissions of 16 TPY and F emissions of 28 TPY (Appendix A, Table A.3). At their typical concentrations, other trace element HAPs do not appear to contribute significantly to emissions.

However, Mn may also need to be monitored because its emissions levels could exceed 10 TPY if higher, although atypical, concentrations of these elements were found in the actual feed coal burned. In the worst case scenario, more than 575 TPY could be emitted. (Data are not at hand to consider this category at the 2-S.D. level.)

\subsubsection{North Park, Colorado}

Calculations indicate that projected total annual emissions from a new, modern, 5C. $-\mathrm{MWe}$, coal-fired power plant burning Colorado bituminous coal are likely to exceed 64 TPY, with probable $\mathrm{Cl}$ emissions of 18 TPY and F emissions of 44 TPY (Appendix A, Table A.3.1).

At the 2-S.D. level, more than 272 TPY could be emitted; in the worst case scenario, more than 510 TPY could be emitted.

\subsubsection{Hanna, Wyoming}

Calculations indicate that projected total annual emissions from a new, modern, 500-MWe, coal-fired power plant burning Wyoming bituminous coal are likely to exceed 35 TPY, with probable $\mathrm{Cl}$ emissions of 15 TPY and F emissions of 18 TPY (Appendix A, Table A.3.2). 
At the 2-S.D. level, total emissions could reach 82 TPY. In the worst case scenario, nearly 84 TPY could be emitted.

\subsubsection{Black Mesa, Arizona}

Calculations indicate that projected total annual emissions from a new, modern, 500-MWe, coal-fired power plant burning Arizona bituminous coal are likely to exceed 34 TPY, with probable $\mathrm{Cl}$ emissions of 20 TPY and F emissions of 13 TPY (Appendix A, Table A.3.3).

At the 2-S.D. level, total emissions could reach 58 TPY. In the worst case scenario, 63 TPY could be emitted.

\subsubsection{Uinta, Utah}

Calculations indicate that projected total annual emissions from a new, modern, 500-MWe, coal-fired power plant burning Utah bituminous coal are likely to exceed 32 TPY, with probable $\mathrm{Cl}$ emissions of 11 TPY and $\mathrm{F}$ emissions of 20 TPY (Appendix A, Table A.3.4).

At the 2-S.D. level, total emissions could more than double to reach 80 TPY. In the worst case scenario, total emissions could exceed 110 TPY.

\subsection{NORTHERN PLAINS LIGNITE AND SUBBITUMINOUS COAL}

From a regional viewpoint and on the basis of the typical characteristics of Northern Plains lignites and subbituminous coals, a new, modern, 500-MWe, coal-fired power plant would probably exceed the 25-TPY CAAA limit and may thus be subject to monitoring. Calculations indicate that total annual emissions could exceed 46 TPY, with probable $\mathrm{Cl}$ emissions of 22 TPY and F emissions of 22 TPY (Appendix A, Table A.4). At their typical concentrations, other trace element HAPs do not appear to contribute significantly to emissions.

However, As, $\mathrm{Mn}$, and $\mathrm{Hg}$ may also need to be monitored because each of their emissions levels could exceed 10 TPY if higher, although atypical, concentrations of these elements were found in the actual feed coal burned. In the worst case scenario, more than 800 TPY could be emitted. (Data are not at hand to consider this category at the 2-S.D. level.)

It is notable that this region's coal is the only case in this study that projects $\mathrm{Hg}$ as a significant HAP. 


\subsubsection{North Dakota Lignite}

Calculations indicate that projected total annual emissions from a new, modern, 500-MWe, coal-fired power plant burning North Dakota lignite are likely to exceed 52 TPY, with probable $\mathrm{Cl}$ emissions of 34 TPY and F emissions of 15 TPY (Appendix A, Table A.4.1).

At the 2-S.D. level, total emissions could exceed 81 TPY; in the worst case scenario, 83 TPY could be emitted.

\subsubsection{Wyoming Subbituminous Coal}

Calculations indicate that projected total annual emissions from a new, modern, 500-MWe, coal-fired power plant burning Wyoming subbituminous coal are likely to exceed 57 TPY, with probable $\mathrm{Cl}$ emissions of 22 TPY and F emissions of 32 TPY (Appendix A, Table A.4.2).

At the 2-S.D. level, total emissions could reach 127 TPY. Also, Mn may need to be monitored because its emissions level could exceed 10 TPY if a higher, although atypical, concentration of this element were found in the actual feed coal burned; in the worse case scenario, nearly 180 TPY could be emitted.

\subsubsection{Montana Subbituminous Coal}

Calculations indicate that projected total annual emissions from a new, modern, 500-MWe, coal-fired power plant burning Montana subbituminous coal are likely to exceed 36 TPY, with probable $\mathrm{Cl}$ emissions of 17 TPY and F emissions of 18 TPY (Appendix A, Table A.4.3).

At the 2-S.D. level, total emissions could reach $68 \mathrm{TPY}$; in the worst case scenario, total emissions could reach 76 TPY.

\subsection{GULF LIGNITE}

From a regional viewpoint and on the basis of the typical characteristics of Gulf lignites, a new, modern, 500-MWe, coal-fired power plant would most probably exceed the 25-TPY CAAA limit and may thus be subject to monitoring. Calculations indicate total annual emissions could reach 367 TPY, with probable $\mathrm{Cl}$ emissions of 215 TPY, F emissions of 124 TPY, and Mn emissions of 16 TPY (Appendix A, Table A.5). At thuir typical concentrations, other trace element HAPs do not appear to contribute significantly to emissions.

In the worst case scenario, more than 925 TPY could be emitted. (Data are not at hand to consider this category at the 2-S.D. level.) 
Calculations indicate that projected total annual emissions from a new, modern, 500-MWe, coal-fired power plant burning Alabama lignite are likely to reach 398 TPY, with probable Cl emissions of 229 TPY, F emissions of 135 TPY, and Mn emissions of 21 TPY (Appendix A, Table A.5.1).

At the 2-S.D. level, total emissions could exceed 862 TPY; in the worst case scenario, more than 940 TPY could be emitted.

\subsection{ALASKAN SUBBITUMINOUS COAL}

On the basis of the typical characteristics of Alaskan subbituminous coals, a new, modern, 500-MWe, coal-fired power plant would probably exceed the 25 TPY CAAA limit and may thus be subject to monitoring. Calculations indicate total annual emissions could exceed 84 TPY, with probable $\mathrm{Cl}$ emissions of 24 TPY and F emissions of 57 TPY (Appendix A, Table A.6). At their typical concentrations, other trace element HAPs do not appear to contribute significantly to emissions.

At the 2-S.D. level, total emissions could reach 195 TPY; in the worst case scenario, more than 248 TPY could be emitted.

\subsection{PENNSYLVANIAN ANTHRACITE}

On the basis of the typical characteristics of Pennsylvanian anthracites, a new, modern, 500-MWe, coal-fired power plant would probably exceed the 25-TPY CAAA limit and may thus be subject to monitoring. Calculations indicate total annual emissions could reach 39 TPY, with probable $\mathrm{Cl}$ emissions of 15 TPY and F emissions of 21 TPY (Appendix A, Table A.7). At their typical concentrations, other trace element HAPs do not appear to contribute significantly to emissions.

At the 2-S.D. level, total emissions exceed 114 TPY; in the worst case scenario, total emissions could exceed 230 TPY. 


\section{MEASURED ORGANIC MAZARDOUS AIR POLLUTANT EMISSIONS}

\subsection{IDENTIFICATION AND QUANTIFICATION OF ORGANIC EMISSIONS}

Various researchers have detected and measured organic emissions from conventional PCF power plants. A sampling of their research, culled from the results of Warman (1984), Eschenroeder et al. (1985), and Zelenski et al. (1980), is summarized in Table 24. The organic compounds of significant concentration are listed in the table. Note that, for the most part, these specifically identified organic compounds have been lumped, for purposes of the 1990 CAAA, into the POM category. Only benzene, biphenyl, ethylbenzene, xylene(s), naphthalene, and toluene are listed separately in the CAAA HAP listing. All the organic compound entries in Table 24 are measured and representative concentrations of actually detected emissions, not just sample calculations.

The Warman data indicate measured flue gas concentrations of organic emissions in micrograms per cubic meter. The Eschenroeder et al. data indicate measured concentrations of flue gas and fly ash organic emissions from the stack and in the plume, also in micrograms per cubic meter. The Zelenski et al. data indicate measured concentrations of organic emissions from the stack in $10^{-5}$ nanograms per Joul?.

\subsection{ORGANIC EMISSIONS BY PLANT TYPE AND TYPE OF FIRING}

PAH emissions from coal-fired plants can depend on a considerable number of factors. Among these are the size of the plant, the load factor, the type of coal, the type of burner, and the flue gas cleaning equipment. The load factor and boiler type are thought to be crucial factors in determining the emissions.

Warman (1984) presents a comprehensive summary of the chemical measurements of organic emissions from coal-fired facilities. The individual data sets presented therein are not only for PCF plants (A-C) (Table 25) but also for plants with moving and fixed grates (DF and G) (Table 26) and plants with fluidized-bed combustors (H-K) (Table 27) with a brief summary of the firing conditions for each case. The significant data are summarized in Tables 25-27.

- Plant A is a dual-fired (pulverized coal/oil) power plant that can produce $350 \mathrm{MWt}$ at full load. The flue gas is passed through an electrostatic precipitator (ESP).

- Plant B is a PCF power plant that can produce $270 \mathrm{MWe}(600 \mathrm{MWt})$ at full load. The boiler is equipped with a high-efficiency ESP. The unit fires a mixture of low-S coals. 
TABLE 24 Significant Organic Emissions Measured from PCF Power Plants

\begin{tabular}{|c|c|c|c|c|}
\hline \multirow[b]{2}{*}{ Organic Compound ${ }^{a}$} & \multirow{2}{*}{$\frac{\begin{array}{c}\text { Concentration } \\
\left(\mu \mathrm{g} / \mathrm{m}^{3}\right)^{\mathrm{b}}\end{array}}{\text { Flue Gas }}$} & \multicolumn{2}{|c|}{$\begin{array}{l}\text { Concentration } \\
\left(\mu \mathrm{g} / \mathrm{m}^{3}\right)^{\mathrm{c}}\end{array}$} & \multirow{2}{*}{$\frac{\begin{array}{c}\text { Concentration } \\
\left(10^{-5} \mathrm{ng} / J\right)^{\mathrm{d}}\end{array}}{\text { Stack }}$} \\
\hline & & Stack & Plume & \\
\hline Anthanthrene & - & 5 & - & $0.46-0.5$ \\
\hline Anthracene & $0.14^{\mathrm{e}}$ & - & $f$ & $0.6-8.3$ \\
\hline $\begin{array}{l}\text { Benzene } \\
\text { (and 2,4-dimethylpentane) }\end{array}$ & - & - & - & 1,520 \\
\hline Benzo(a)anthracene & $0.15^{e}$ & - & 0.069 & $2.40-15.4$ \\
\hline Benzo(b)fluoranthene & $0.23^{\mathrm{e}}$ & - & - & $\begin{array}{r}<0.0035 \\
<0.009^{8}\end{array}$ \\
\hline Benzo(bkj)fluoranthene & $0.88^{h}$ & - & - & - \\
\hline Benzo(ghi)fluoranthene & $1.4^{\mathrm{h}}$ & - & - & - \\
\hline Benzo(k)fluoranthene & $0.12^{e}$ & - & $\mathbf{f}$ & - \\
\hline 1,2-Benzofluorene & - & - & - & $8.6-180$ \\
\hline 2,3-Benzofluorene & - & - & - & 2.7 \\
\hline Benzo(ghi)perylene & $f, e, h$ & 100 & 0.012 & $<0.0035 \cdot 104.3$ \\
\hline Benzoperylene & - & - & - & 0.42 \\
\hline Benzophenanthrene & - & - & - & 270 \\
\hline Benzo(a)pyrene & $\begin{array}{l}0.09^{\mathrm{e}} \\
0.79^{\mathrm{h}}\end{array}$ & 18 & 0.0129 & $0.0035-720$ \\
\hline Benzo(e)pyrene & $\begin{array}{l}0.13^{\mathrm{e}} \\
0.81^{\mathrm{h}}\end{array}$ & 380 & 0.0098 & $<0.0035-64.5$ \\
\hline Biphenyl & - & - & - & 2.4 \\
\hline Chrysene/triphenylene & $0.49^{\mathrm{e}}$ & - & 0.048 & 1.68 \\
\hline Coronene & $\mathrm{f}, \mathrm{h}$ & 31 & - & $<0.0035-8.8$ \\
\hline Dihydroanthracene & - & - & - & 2.9 \\
\hline $\begin{array}{l}\text { 7,12-Dimethyl } \\
\text { benzo(a)anthracene }\end{array}$ & - & - & f & $<0.0035-3.23$ \\
\hline Ethylbenzene & - & - & - & 2,635 \\
\hline Ethylmethylphenanthrene & $2.4^{\mathrm{h}}$ & - & - & - \\
\hline Fluoranthene & $\begin{array}{l}1.24^{\mathrm{e}} \\
22.1^{\mathrm{h}}\end{array}$ & 8 & 0.0027 & $0.07-1,500$ \\
\hline Fluorene & - & - & f & 45 \\
\hline m- and p-Xylenes & - & - & - & 9,193 \\
\hline Methylanthracenes & - & - & - & $0.08-2.1$ \\
\hline Methylcholanthrene & - & - & - & $<0.0035-1.92$ \\
\hline Methyinaphthalenes & - & - & - & $1.1-1.2$ \\
\hline Methylphenanthrene(s) & $0.42^{\mathrm{e}}$ & - & - & $<5.9$ \\
\hline Methylpyrene & - & - & - & 30 \\
\hline Naphthalene & - & - & - & 1.9 \\
\hline o-Xylene & - & - & - & 2,028 \\
\hline Peryle-a & $f, e, h$ & - & $<0.002$ & $<0.0035-6.8$ \\
\hline Phenanthrene & $\begin{array}{l}1.42^{\mathrm{e}} \\
15.3^{\mathrm{h}}\end{array}$ & 34 & f & $1.9 \cdot 1,100$ \\
\hline Phenylnaphthylene & $1.7^{\mathrm{h}}$ & - & -- & - \\
\hline Pyrene & $0.44^{\mathrm{e}}$ & 180 & 0.0164 & $0.01 \cdot 1,100$ \\
\hline Toluene & - & - & - & 1,230 \\
\hline
\end{tabular}

a POM or PAH, unless otherwise noted in bold as a specifically listed 1990 CAAA HAP.

b Warman (1984).

c Eschenroeder et al. (1985).

d Zelenski et al. (1980).

e PCF plants, where emissions $>0.05 \mu \mathrm{g} / \mathrm{m}^{3}$ flue gas.

$f$ Detected but not quantified.

$g$ Benzofluoranthenes, in general.

h Coal-fired plants with fixed grate, where emissions $>0.5 \mu \mathrm{g} / \mathrm{m}^{3}$. 
TABLE 25 PAH Concentrations Measured in Flue Gas $\left(\mu \mathrm{g} / \mathrm{m}^{3}\right)$ from PCF Plants

\begin{tabular}{|c|c|c|c|c|c|c|c|c|c|}
\hline \multirow{3}{*}{\begin{tabular}{l}
\multicolumn{1}{c}{ Compound } \\
Anthracene \\
Anthracenone/ \\
phenanthrenone
\end{tabular}} & \multicolumn{2}{|c|}{ Plant A } & \multicolumn{5}{|c|}{ Plant B } & \multicolumn{2}{|c|}{ Plant $C$} \\
\hline & 0.04 & 0.04 & 0.14 & 0.14 & $<0.02$ & $<0.01$ & $<0.01$ & $<0.1$ & $<0.1$ \\
\hline & & & & & & 0.28 & $<0.01$ & & \\
\hline Benzo(a)anthracene & 0.15 & $<0.02$ & 0.06 & 0.05 & $<0.02$ & $<0.01$ & $<0.01$ & $<0.1$ & $<0.1$ \\
\hline Benzo(b)fluoranthene & 0.23 & 0.07 & 0.03 & 0.04 & $<0.02$ & & & & \\
\hline Benzo(k)fluoranthene & 0.12 & 0.03 & 0.02 & 0.02 & $<0.02$ & & & & \\
\hline Benzo(ghi)perylene & & & & & & $<0.01$ & $<0.01$ & $<0.1$ & $<0.1$ \\
\hline Benzo(a)pyrene & 0.09 & 0.04 & 0.02 & 0.03 & $<0.02$ & $<0.01$ & $<0.01$ & $<0.1$ & $<0.1$ \\
\hline Benzo(e)pyrene & 0.13 & 0.03 & 0.01 & 0.01 & $<0.02$ & $<0.01$ & $<0.01$ & $<0.1$ & $<0.1$ \\
\hline Chrysene/triphenylene & 0.49 & 0.25 & 0.23 & 0.31 & $<0.02$ & $<0.01$ & $<0.01$ & $<0.1$ & $<0.1$ \\
\hline Fluoranthene & 1.24 & 0.35 & 0.60 & 0.53 & $<0.02$ & $<0.01$ & $<0.01$ & $<0.1$ & $<0.1$ \\
\hline Ideno( $1,2,3, \mathrm{~cd})$ pyrene & & & & & & $<0.01$ & $<0.01$ & $<0.1$ & $<0.1$ \\
\hline 2-Methylanthracene & 0.02 & 0.04 & 0.02 & 0.03 & $<0.02$ & & & & \\
\hline $\begin{array}{l}\text { 4,5-Methylene- } \\
\text { phenanthrene }\end{array}$ & 0.01 & 0.02 & 0.02 & 0.01 & $<0.02$ & & & & \\
\hline $\begin{array}{l}\text { Methylphenanthrene/ } \\
\text { anthracene- } \\
\text { isomer } 1\end{array}$ & 0.07 & 0.04 & 0.11 & 0.07 & $<0.02$ & & & & \\
\hline $\begin{array}{l}\text { Methylphenanthrene/ } \\
\text { anthracene - } \\
\text { isomer } 2\end{array}$ & 0.10 & 0.05 & 0.13 & 0.09 & $<0.02$ & & & & \\
\hline $\begin{array}{l}\text { Methylphenanthrene/ } \\
\text { anthracene - } \\
\text { isomer } 3\end{array}$ & 0.06 & 0.04 & 0.09 & 0.06 & $<0.02$ & & & & \\
\hline 1-Methylphenanthrene & 0.07 & 0.04 & 0.09 & 0.06 & $<0.02$ & & & & \\
\hline 1-Methylpyrene & $<0.02$ & $<0.02$ & $<0.02$ & $<0.02$ & $<0.02$ & & & & \\
\hline 4-Methylpyrene & $<0.02$ & $<0.02$ & $<0.02$ & $<0.02$ & $<0.02$ & & & & \\
\hline Perylene & & & & & & $<0.01$ & $<0.01$ & $<0.1$ & $<0.1$ \\
\hline Phenanthrene & 0.55 & 0.19 & 1.42 & 1.11 & $<0.02$ & & & $<0.1$ & $<0.1$ \\
\hline Pyrene & 0.44 & 0.18 & 0.29 & 0.24 & $<0.02$ & $<0.01$ & $<0.01$ & $<0.1$ & $<0.1$ \\
\hline
\end{tabular}

Source: Warman (1984).

- Plant C is a PCF power plant of the Benson type that can produce $720 \mathrm{MWe}$ at full load. The flue gas system consists of an ESP and a wet-lime FGD unit. About 20\% of the total gas flow is treated in the FGD unit; the untreated flue gas is by-passed. The $\mathrm{SO}_{2}$ removal efficiency is greater than $80 \%$.

- Plant $\mathrm{D}$ is a coal-fired industrial steam boiler that can produce $40 \mathrm{t}^{*}$ steam $/ \mathrm{h}$ at $6 \mathrm{MPa}$ and $440^{\circ} \mathrm{C}$. During the tests, the load was $78 \%$ $(25 \mathrm{MWt})$. The low-S $(0.9 \%) \mathrm{coal}$ is fired on a moving grate $\left(23 \mathrm{~m}^{2}\right)$. The flue gas cleaning equipment consists of a multiple cyclone unit and a secondary cyclone circuit.

- Plant $\mathrm{E}$ is a coal-fired steam boiler of the La Mont type with a heat exchanger that provides district heating. The boiler can produce $35 \mathrm{t}$ steam/h at $2.7 \mathrm{MPa}$ and $425^{\circ} \mathrm{C}$. The low-S coal $(0.7 \%)$ is fired on a

\footnotetext{
"A metric ton (tonne) is abbreviated "t." A short ton (2,000 lb) is abbreviated "T."
} 
TABLE 26 PAH Concentrations Measured in Flue Gas $\left(\mu \mathrm{g} / \mathrm{m}^{3}\right)$ from Coal-Fired Plants with Grates

\begin{tabular}{|c|c|c|c|c|c|}
\hline \multirow[b]{2}{*}{ Compound } & \multicolumn{4}{|c|}{ Moving Grate } & \multirow{2}{*}{$\frac{\text { Fixed Grate }}{\text { Plant G }}$} \\
\hline & Plant D & Plar & t $E$ & Plant F & \\
\hline Anthracene & $<0.1$ & $\mathbf{a}$ & a & $<0.1$ & $<0.1$ \\
\hline Benzo(c)acenaphthylene & & & & & $<0.1$ \\
\hline Benzo(a)anthracene & $<0.1$ & $<0.01$ & $<0.01$ & $<0.1$ & 1.4 \\
\hline Benzo(bkj)fluoranthene & & & & & 0.88 \\
\hline Benzo(ghi)fluoranthene & & & & & 1.4 \\
\hline Benzofluorene & & & & & $<0.1$ \\
\hline Benzo(ghi)perylene & $<0.1$ & $<0.01$ & $<0.01$ & $<0.1$ & $<0.1$ \\
\hline Benzo(a)pyrene & $<0.1$ & $<0.01$ & $<0.01$ & $<0.1$ & 0.79 \\
\hline Benzo(e)pyrene & $<0.1$ & $<0.01$ & $<0.01$ & $<0.1$ & 0.81 \\
\hline Binaphthyl & & & & & $<0.1$ \\
\hline Chrysene/triphenylene & $<0.1$ & $<0.01$ & $<0.01$ & $<0.1$ & $<0.1$ \\
\hline Coronene & & & & & $<0.1$ \\
\hline Dibenzo(ah)anthracene & & & & & $<0.1$ \\
\hline Ethyl-4,5-methylphenanthrene & & & & & 2.4 \\
\hline Fluoranthene & $<0.1$ & $<0.01$ & $<0.01$ & $<0.1$ & 22.1 \\
\hline Ideno(1,2,3,cd)pyrene & $<0.1$ & $<0.01$ & $<0.01$ & $<0.1$ & $<0.1$ \\
\hline 2-Methylanthracene & & & & & $<0.1$ \\
\hline 4,5-Methylenephenanthrene & $<0.1$ & & & & $<0.1$ \\
\hline 1-Methylpyrene & & & & & $<0.1$ \\
\hline Perylene & $<0.1$ & $<0.01$ & $<0.01$ & $<0.1$ & $<0.1$ \\
\hline Phenanthrene & $<0.1$ & $<0.01$ & $<0.01$ & 0.29 & 15.3 \\
\hline Phenylnaphthylene & & & & & 1.7 \\
\hline Pyrene & $<0.1$ & $<0.07$ & $<0.07$ & $<0.1$ & 0.91 \\
\hline
\end{tabular}

a Detected but not quantified.

Source: Warman (1984).

moving grate similar to that of Plant D. The samples were collected in a flue gas stream that is passed through a baghouse filter.

- Plant $\mathrm{F}$ is a spreader stoker, coal- and oil-fired, water-tu've boiler that can produce $130 \mathrm{t}$ steam $/ \mathrm{h}$ at $11.5 \mathrm{MPa}$ and $540^{\circ} \mathrm{C}$. The flue gas is passed through a two-step multiple cyclone unit with 440 little cyclones in step one and 2 big cyclones in step two.

- Plant G is a coal-fired, hot-water boiler with a capacity of $2.1 \mathrm{MWt}$. Because the grate is immovable, the furnace normally is deslagged by hand twice a day. The furnace was nnt deslagged during the test, however. The boiler is equipped with multiple cyclones with full flow circulation. 
TABLE 27 PAH Concentrations Measured in Flue Gas $\left(\mu \mathrm{g} / \mathrm{m}^{3}\right)$ from FBC Plants

\begin{tabular}{|c|c|c|c|c|c|}
\hline \multirow{2}{*}{$\frac{\text { Compound }}{\text { Anthracene }}$} & \multirow{2}{*}{$\frac{\text { Plant H }}{109}$} & \multicolumn{2}{|c|}{ Plant I } & \multirow[t]{2}{*}{ Plant J } & \multirow{2}{*}{$\frac{\text { Plant K }}{0.053}$} \\
\hline & & 1.8 & $<0.1$ & & \\
\hline Benzo(e)acenaphthylene & 21.7 & & & & \\
\hline Benzo(a)anthracene & 32.2 & $<0.1$ & $<0.1$ & $<0.6$ & \\
\hline Benzo(a)fluoranthene & 7.5 & & & & 0.001 \\
\hline $\begin{array}{l}\text { Benzo(b)fluoranthene and/or } \\
\text { benzo(jk)fluoranthene }\end{array}$ & 26.0 & & & & \\
\hline Benzo(ghi)fluoranthene & 23.0 & $<0.1$ & $<0.1$ & & \\
\hline Benzofluorene & 27.6 & & & & \\
\hline Benzo(ghi)perylene & 3.9 & $<0.1$ & $<0.1$ & & \\
\hline Benzo(c)phenanthrene & 14.4 & & & & 0.0002 \\
\hline Benzo(a)pyrene & 12.6 & 0.1 & $<0.1$ & $<0.2$ & 0.0005 \\
\hline Benzo(e)pyrene & 12.5 & $<0.1$ & 0.1 & & \\
\hline Benzylnaphthalene & 1.3 & & & & \\
\hline Chrysene/triphenylene & 18.4 & $<0.1$ & $<0.1$ & $<0.6$ & 0.0038 \\
\hline Dibenzo(ac/ah)anthracene & 1.0 & & & & \\
\hline Dibenzo(ab)fluorene & 20 & & & & \\
\hline Dihydrobenz(a)anthracene & 4.1 & & & & \\
\hline Dimethylphenanthrene & 8.9 & & & & \\
\hline Ethyl-4,5-methylphenanthrene & 8.5 & & & & \\
\hline Fluoranthene & 227 & 11.0 & $<0.3$ & $<1.0$ & 0.026 \\
\hline Ideno $(1,2,3, \mathrm{~cd})$ pyrene & 5.0 & $<0.1$ & $<0.1$ & & \\
\hline 2-Methylanthracene & 2.2 & 1.41 & $<0.1$ & & 0.005 \\
\hline 4,5-Methylphenanthrene & 14 & & & & \\
\hline 1-Methylpyrene & & & & & 0.001 \\
\hline Perylene & 2.1 & $<0.1$ & $<0.1$ & & \\
\hline Phenanthrene & 657 & 33.2 & 0.28 & $<1.0$ & \\
\hline Pyrene & 205 & 5.8 & $<0.1$ & $<1.0$ & 0.009 \\
\hline Trimethylphenanthrene & 1.9 & & & & \\
\hline
\end{tabular}

Source: Warman (1984).

- Plant $\mathrm{H}$ is a small, demonstration, atmospheric fluidized-bed combustcr (AFBC) that also produces hot water for district heating.

- Plant I is a circulating AFBC of the Pyroflow ${ }^{\circledR}$ type that can produce $90 \mathrm{t}$ steam $/ \mathrm{h}$ at $8.4 \mathrm{MPa}$ and $500^{\circ} \mathrm{C}$. The $\mathrm{FBC}$ is equipped with an ESP. No limestone was used during the test.

- Plant $\mathrm{J}$ is an AFBC with bed area of $10 \mathrm{~m}^{2}$; its boiler is equipped with a superheater and an economizer. The fuel is fed to the bed through an over-bed feed system.

- Plant $\mathrm{K}$ is a pressurized fluidized-bed combustor (PFBC) constructed for research by Exxon. The facility has a $0.32-\mathrm{m}$ diameter reactor that 
operates at $890^{\circ} \mathrm{C}, 900 \mathrm{kPa}, 1.2 \mathrm{~m} / \mathrm{s}$ superficial velocity, and $40 \%$ excess air. Coal consumption is $75 \mathrm{~kg} / \mathrm{h}$, with $11.0 \mathrm{~kg}$ dolomite sorbent/h fed to the reactor. During testing, a molar ratio of $1.25 \mathrm{Ca} / \mathrm{S}$ was calculated. The flue gas was passed through a two-stage cyclone separator.

Zelenski et al. (1980) present measured organic emissions from the stack (Table 28), which are primarily PAHs. They also note the types of firing, as follows: tangential, corner, vertical, chain-grate stoker, front-walled, opposed, opposed-downward-inclined, cyclone, and spreader. 
TABLE 28 Organic Stack Emissions Measured from Coal-Fired Conventional Power Plants $\left(1^{-5} \mathbf{n g} / \mathbf{J}\right)$

\begin{tabular}{|c|c|c|}
\hline Compound $^{a}$ & Emission & Type(s) of Firing ${ }^{b}$ \\
\hline Anthanthrene & $0.46 \cdot 0.5$ & Tangential, corner \\
\hline Anthracene/phenanthrene & $0.6 \cdot 8.3$ & Corner \\
\hline Benzo(a)anthracene & $2.40-15.4$ & Vertical, corner \\
\hline Benzofluoranthenes & $<0.0035-<0.009$ & \\
\hline 1,2-Benzoflurorene & $8.6-180$ & Chain-grate stoker \\
\hline 2,3-Benzofluorene & 2.7 & \\
\hline Benzo(ghi)perylene & $<0.0035-104.3$ & $\begin{array}{l}\text { Vertical, front-walled, tangential, opposed-downward- } \\
\text { inclined, cyclone, corner }\end{array}$ \\
\hline Benzoperylene & 0.42 & \\
\hline Benzophenanthrene & 270 & \\
\hline Benzo(c)phenanthrene & $<0.0035-<0.007$ & \\
\hline Benzo(a)pyrene & $0.0055-720$ & $\begin{array}{l}\text { Vertical, front-walled, tangential, opposed-downward- } \\
\text { inclined, cyclone, spreader and chain-grate stoker, } \\
\text { corner }\end{array}$ \\
\hline Benzo(e)pyrene & $<0.0035-64.5$ & $\begin{array}{l}\text { Vertical, front-walled, tangential, opposed-downward- } \\
\text { inclined, cyclone, spreader stoker, corner }\end{array}$ \\
\hline Biphenyl & 2.4 & \\
\hline Chrysene & 1.68 & \\
\hline Chrysene/benzo(a)anthracene & $<0.0035-0.22$ & \\
\hline Coronene & $<0.0035-8.8$ & $\begin{array}{l}\text { Tangential, opposed-downward-inclined, cyclone, } \\
\text { spreader stoker, corner }\end{array}$ \\
\hline Dibenzo(ah)anthracene & $<0.0035-<0.007$ & \\
\hline Dibenzo(ai, ah)pyrenes & $<0.0035-<0.007$ & \\
\hline Dibenzo(cg)carbazolene & $<0.0035-0.007$ & \\
\hline Dihydroanthracene & 2.9 & \\
\hline 7,12-Dimethylbenzo(a)anthrocene & $<0.0035-3.23$ & Opposed \\
\hline 2,4-Dimethylpentane and & 1,520 & \\
\hline Ethylbenzene & 2,635 & \\
\hline Fluoranthene & $0.07-1,500$ & $\begin{array}{l}\text { Vertical, front-walled, tangential, opposed-downward- } \\
\text { inclined, cyclone, spreader and chain-grate stoker, } \\
\text { corner }\end{array}$ \\
\hline Fluorene & 45 & Chain-grate stoke: \\
\hline Indeno $(1,2,3-c d)$ pyrene & $<0.0035-<0.007$ & \\
\hline m- and p-Xylenes & 9,193 & \\
\hline Methylanthracenes & $0.08-2.1$ & \\
\hline Methylbenzopyrenes & $<0.0035-<0.007$ & \\
\hline 3-Methylcholanthrene & $<0.0035-1.92$ & Opposed \\
\hline Methylchrysenes & $<0.0035-<0.007$ & \\
\hline Methylnaphthalenes & $1.1-1.2$ & \\
\hline Methylphenanthrene & $<5.9$ & \\
\hline Methylpyrene & 30 & Chain-grate stoker \\
\hline Methylpyrene/fluoranthene & $<0.0035-0.45$ & \\
\hline Naphthalene & 1.9 & \\
\hline o-Xylene & 2,028 & \\
\hline Perylene & $<0.6035 \cdot 6.8$ & Vertical, tangential, cyclone, corner \\
\hline Phenanthrene & $1.9 \cdot 1,100$ & $\begin{array}{l}\text { Front-walled, tangential, chain-grate stoker, corner, } \\
\text { vertical }\end{array}$ \\
\hline Pyrene & $0.01-1,100$ & $\begin{array}{l}\text { Vertical, front-walled, tangential, opposed-downward- } \\
\text { inclined, cyclone, spreader and chain-grate stoker, } \\
\text { corner }\end{array}$ \\
\hline Toluene & 1,230 & \\
\hline
\end{tabular}

a PAH, unless otherwise noted in bold as an HAP.

b If unlisted, then not mentioned.

Source: Zelenski et al. (1980). 


\section{HIGHLIGHTS AND FUTURE DIRECTIONS}

Beyond the extensive characterizations and various discussions presented in this report, several topical areas stand out that deserve continued characterization and study for consideration in the regulators' and policymakers' arenas. These highlighted research and development areas include the following:

1. Statistical characterization of trace elements inherent in U.S. coal resources by region, state, and rank. The appropriate presentation and assimilation of these data will allow policymakers and decision makers to consider discrete units of heterogeneous coal by location and rank. However, CAAA regulatory needs might be more fully met by additional characterization and assimilation of existing trace element coal data into useful blocks for statistical manipulation and analysis and, more importantly, their incorporation into existing models ${ }^{*}$ that forecast emissions. In this way, potential or probable air toxic emissions could be calculated by unit, state, region, and nation, just as $\mathrm{SO}_{2}, \mathrm{NO}_{\mathrm{x}}$, and particulate emissions are forecast today.

2. Projected emissions from real, not hypothetical, coal-fired plants on the basis of inherent trace element concentrations. Although calculated conservatively in this report, projections for real, existing coal-fired plants will allow policymakers to consider only those HAP trace elements that are of significant importance to public health, such as $\mathrm{Cl}$, $\mathrm{F}, \mathrm{Hg}, \mathrm{Mn}$, and $\mathrm{Se}$. In this way, potential electric utility regulation of HAP trace elements could be better focused.

3. Organic compounds derived from coal-fired combustion. If we can identify and quantify those organic compounds actually emitted relative to their associated combustion conditions and designs, policymakers will be able to focus only on those organic compounds actually present in quantities significant enough to contribute to the public's detriment.

An additional and obvious extension of this work is :o determine how much U.S. coal is likely to be placed in jeopardy by becoming noncompliant under the new CAA and potential EPA regulations, on the basis of specific source coal characterizations involving the listed HAPs or their precursors. This extension leads to the question of the economic competitiveness of various coal-related industries and the tremendous potential effect on the domestic economy.

It is also apparent that modeling studies will be enhanced by the source data collected and manipulated in this study for subsequent applications. Applicable computer

\footnotetext{
"The data appear to lend themselves to being meshed with existing util"ty model input data bases such as the Coal Supply and Transportation Model (CSTM) (DOE 1987).
} 
models exist at Argonne National Laboratory and can be considered for modification and expansion with relative ease and swiftness for subsequent policy scenario development.

Moreover, the DOE, the Utility Air Regulatory Group, the EPRI, and the EPA are reportedly collaborating to expand on the study of HAPs from utility boilers. Their effort will involve measurements at various power plants with different boiler designs, $\mathrm{NO}_{\mathrm{x}}$ control methods, particulate control devices, and $\mathrm{SO}_{2}$ removal system 1 (wet and dry). These measurements may enable prediction of the potential air toxic emissions from coal-fired boilers in 1995 and 2000; after that time, controls are expected to be installed to meet the requirements of the acid rain title of the CAAA (Brown et al. 1991).

Finally, DOE (1992) has stated its intention to join with EPRI in assessing selected HAPs from a number of utilities that use different pollution control and process systems burning bituminous or subbituminous coals. The objectives of this study are:

1. To determine the removal efficiencies of pollution control systems for selected pollutants and the concentrations of the respective pollutants associated with the particulate fraction of the flue gas as a function of particle size, and

2. To determine mass balances solected pollutants for a variety of different input, and output streams of the power plants as well as for the entire plant.

For regulators, policymakers, and decision makers, these initiatives should go a long way toward supporting or refuting the concerns raised in this study. 
98

$\cdot$

$-$

$=$ 
APPENDIX A:

TABLES LISTING THE CALCULATED ANNUAL TRACE ELEMENT EMISSIONS FROM A NEW, MODERN, 500-MWe POV'ER PLANT FIRING U.S. COAL 
TABLE A.1 Calculated Annual Trace Element Emissions ${ }^{a, b}$ from a New, Modern, 500-MWe Power Plant ${ }^{c}$ Firing U.S. Appalachian Bituminous Coal

\begin{tabular}{|c|c|c|c|c|}
\hline Element & $\begin{array}{c}\text { Typical } \\
\text { Content } \\
(\mathrm{ppm})^{\mathbf{e}}\end{array}$ & $\begin{array}{c}\text { Calculated } \\
\text { Emirsions } \\
\text { F ed on } \\
\text { 1ypical } \\
\text { Content } \\
\text { (TPY) } \\
\end{array}$ & $\begin{array}{c}\text { Maximum } \\
\text { Content } \\
(\mathrm{ppm})^{\mathrm{f}}\end{array}$ & $\begin{array}{c}\text { Calculated } \\
\text { Emissions } \\
\text { Based on } \\
\text { Maximum } \\
\text { Content } \\
\text { (TPY) }\end{array}$ \\
\hline $\mathrm{Sb}$ & 1.2 & 0.03 & 35 & 0.90 \\
\hline As & 27 & 0.81 & 354 & 10.7 \\
\hline $\mathrm{Be}$ & 2 & 0.04 & 25 & 0.54 \\
\hline $\mathrm{Cd}$ & 0.7 & 0.02 & 4.02 & 0.12 \\
\hline $\mathrm{Cl}$ & 207 & 22.3 & $8,000^{\mathrm{g}, \mathrm{h}}$ & 862 \\
\hline $\mathrm{Cr}$ & 20 & 0.22 & 220 & 2.4 \\
\hline Co & 7 & 0.09 & 930 & 12.0 \\
\hline $\mathrm{F}$ & 80 & 25.9 & 1,900 & 615 \\
\hline $\mathrm{Pb}$ & 15.3 & 0.30 & 86 & 1.67 \\
\hline $\mathrm{Mn}$ & 620 & 13.4 & 1,400 & 30.2 \\
\hline $\mathrm{Hg}$ & 0.24 & 0.23 & 3.2 & 3.07 \\
\hline $\mathrm{Ni}$ & 15 & 0.06 & 220 & 0.95 \\
\hline $\mathrm{P}$ & 372 & 0.40 & $6,000^{h, i}$ & 6.46 \\
\hline Se & 4.7 & 0.73 & 150 & 23.3 \\
\hline Th & 4.9 & 0.02 & 10 & 0.04 \\
\hline $\mathrm{U}$ & 1.4 & 0.02 & 19 & 0.24 \\
\hline Total & & 64.57 & & $1,569.59$ \\
\hline
\end{tabular}

a Bignoli (1989) provides several estimates of the quantity of elements expected to be mobilized in the EEC in the future from new PCF power plants.

b Szpunar, C.B., preliminary assessment results in progress, Argonne National Laboratory, Argonne, Illinois; these projections are based on current scientific thought about element partitioning during coal firing and additional unpublished estimates of the quantity of elements expected to be mobilized in the future from new PCF power plants.

c Hypothetical, new, modern, stringently regulated plant; particulate capture assumed to be $99.8 \%$; compliance FGD, although unspecified as to type; and operation at a $70 \%$ capacity factor.

d The coal is assumed to have a calorific value of $12,890 \mathrm{Btu} / \mathrm{b}$ (typical).

e Swanson et al. (1976) provide coal trace element data.

f Zubovic et al. (1979).

g Gluskoter et al. (1977).

h Henderson et al. (1985).

i Virginia coals only. 
TABLE A.1.1 Calculated Annual Trace Element Emissions ${ }^{a, b}$ from a New, Modern, 500-MWe Power Plant ${ }^{c}$ Firing U.S. Pennsylvania Bituminous Coal ${ }^{\mathrm{d}}$

\begin{tabular}{|c|c|c|c|c|c|c|}
\hline Element & $\begin{array}{l}\text { Typical } \\
\text { Content } \\
(\text { ppm) }\end{array}$ & $\begin{array}{c}\text { Calculated } \\
\text { Emissions } \\
\text { Based on } \\
\text { Typical } \\
\text { Content } \\
\text { (TPY) }\end{array}$ & $\begin{array}{c}\text { Typical } \\
\text { Content } \\
+2 \text { S.D. } \\
\text { (ppm) }\end{array}$ & $\begin{array}{c}\text { Calculated } \\
\text { Emissions } \\
\text { Based on } \\
\text { Typical } \\
\text { Content } \\
+2 \text { S.D. } \\
\text { (TPY) }\end{array}$ & $\begin{array}{c}\text { Maximum } \\
\text { Content } \\
(\mathrm{ppm})^{\mathrm{e}}\end{array}$ & $\begin{array}{c}\text { Calculated } \\
\text { Emissions } \\
\text { Based on } \\
\text { Maximum } \\
\text { Content } \\
\text { (TPY) }\end{array}$ \\
\hline $\mathrm{Sb}$ & 1.2 & 0.03 & 4.2 & 0.10 & 8.8 & 0.23 \\
\hline As & 31 & 0.97 & 115 & 3.60 & 294 & 9.17 \\
\hline $\mathrm{Be}$ & 2.8 & 0.06 & 6.0 & 0.13 & 7 & 0.16 \\
\hline Cd & 0.99 & 0.03 & 2.53 & 0.08 & 4.02 & 0.12 \\
\hline $\mathrm{Cl}$ & 280 & 31.2 & 570 & 63.5 & 620 & 69.0 \\
\hline $\mathrm{Cr}$ & 25 & 0.28 & 59 & 0.66 & 70 & 0.78 \\
\hline Co & 15 & 0.20 & 91 & 1.21 & 300 & 4.00 \\
\hline $\mathbf{F}$ & 99 & 33.0 & 241 & 80.4 & 300 & 100 \\
\hline $\mathrm{Pb}$ & 17.6 & 0.35 & 40.2 & 0.80 & 61.9 & 1.24 \\
\hline $\mathrm{Mn}$ & 65 & 1.45 & 171 & 3.81 & 400 & 8.91 \\
\hline $\mathrm{Hg}$ & 0.39 & 0.39 & 1.43 & 1.43 & 3.3 & 3.27 \\
\hline $\mathrm{Ni}$ & 27 & 0.12 & 103 & 0.46 & 300 & 1.44 \\
\hline $\mathbf{P}$ & 610 & 0.68 & 1,296 & 1.44 & 1,400 & 1.56 \\
\hline Se & 5.3 & 0.8 & 13.5 & 2.16 & 18.0 & 2.89 \\
\hline $\mathrm{Th}$ & 5.3 & $0.5 \%$ & 12.9 & 0.05 & 20.5 & 0.09 \\
\hline $\mathrm{U}$ & 1.3 & 0.02 & 3.3 & 0.05 & 4.7 & 0.06 \\
\hline Total & & 69.65 & & 159.88 & & 202.92 \\
\hline
\end{tabular}

a Bignoli (1989) provides several estimates of the quantity of elements expected to be mobilized in the EEC in the future from new PCF power plants.

b Szpunar, C.B., preliminary assessment results in progress, Argonne National Laboratory, Argonne, Mlinois; these projections are based on current scientific thought about element partitioning during coal firing and additional unpublished estimates of the quantity of elements expected to be mobilized in the future from new PCF power plants.

c Hypothetical, new, modern, stringently regulated plant; particulate capture assumed to be $99.8 \%$; compliance FGD, although unspecified as to type; and operation at a $70 \%$ capacity factor.

d The coal is assumed to have a calorific value of $12,470 \mathrm{Btu} / \mathrm{lb}$ (typical).

e Swanson et al. (1976) provide coal trace element data. 
TABLE A.1.2 Calculated Annual Trace Element Emissions ${ }^{a, b}$ from a New, Modern, 500-MWe Power Plant ${ }^{\mathrm{c}}$ Firing U.S. Eastern Kentucky Bituminous Coal ${ }^{\mathbf{d}}$

\begin{tabular}{|c|c|c|c|c|c|c|}
\hline Element & $\begin{array}{l}\text { Typical } \\
\text { Content } \\
\text { (ppm) }^{\mathrm{e}}\end{array}$ & $\begin{array}{c}\text { Calculated } \\
\text { Emissions } \\
\text { Based on } \\
\text { Typical } \\
\text { Content } \\
\text { (TPY) }\end{array}$ & $\begin{array}{c}\text { Typical } \\
\text { Content } \\
+2 \text { S.D. } \\
\text { (ppm) }\end{array}$ & $\begin{array}{c}\text { Calculated } \\
\text { Emissions } \\
\text { Based on } \\
\text { Typical } \\
\text { Content } \\
+2 \text { S.D. } \\
\text { (TPY) }\end{array}$ & $\begin{array}{c}\text { Maximum } \\
\text { Content } \\
(\mathrm{ppm})^{\mathrm{e}}\end{array}$ & $\begin{array}{c}\text { Calculated } \\
\text { Emissions } \\
\text { Based on } \\
\text { Maximum } \\
\text { Content } \\
\text { (TPY) }\end{array}$ \\
\hline $\mathrm{Sb}$ & 1.8 & 0.05 & 4.8 & 0.13 & 8.8 & 0.25 \\
\hline As & 41 & 1.37 & 161 & 5.38 & 300 & 10.0 \\
\hline $\mathrm{Be}$ & 4.1 & 0.10 & 7.9 & 0.19 & 7.0 & 0.17 \\
\hline $\mathrm{Cd}$ & 0.21 & 0.007 & 0.47 & 0.02 & 0.49 & 0.02 \\
\hline $\mathrm{Cl}$ & 183 & 21.9 & 461 & 55.2 & 500 & 59.9 \\
\hline $\mathrm{Cr}$ & 15 & 0.18 & 33 & 0.40 & 50 & 0.60 \\
\hline Co & 7 & 0.10 & 15 & 0.21 & 20 & 0.29 \\
\hline $\mathbf{F}$ & 108 & 38.7 & 318 & 114 & 460 & 165 \\
\hline $\mathrm{Pb}$ & 17.3 & 0.37 & 46.7 & 1.00 & 69.9 & 1.51 \\
\hline $\mathrm{Mn}$ & 87 & 2.08 & 471 & 11.3 & 1,000 & 23.9 \\
\hline $\mathrm{Hg}$ & 0.21 & 0.22 & 0.71 & 0.74 & 1.30 & 1.38 \\
\hline $\mathrm{Ni}$ & 15 & 0.07 & 33 & 0.15 & 50 & 0.24 \\
\hline $\mathbf{P}$ & 182 & 0.22 & 918 & 1.11 & 1,900 & 2.27 \\
\hline $\mathrm{Se}$ & 6.4 & 1.10 & 13.4 & 2.30 & 14.0 & 2.41 \\
\hline Th & 7.7 & 0.04 & 23.3 & 0.12 & 47.8 & 0.23 \\
\hline $\mathbf{U}$ & 2.4 & 0.03 & 7.2 & 0.09 & 10.5 & 0.15 \\
\hline Total & & 66.537 & & 192.34 & & 268.32 \\
\hline
\end{tabular}

a Bignoli (1989) provides several estimates of the quantity of elements expected to be mobilized in the EEC in the future from new PCF power plants.

b Szpunar, C.B., preliminary assessment results in progress, Argonne National Laboratory, Argonne, Illinois; these projections are based on current scientific thought about element partitioning during coal firing and additional unpublished estimates of the quantity of elements expected to be mobilized in the future from new PCF power plants.

c Hypothetical, new, modern, stringently regulated plant; particulate capture assumed to be $99.8 \%$; compliance FGD, although unspecified as to type; and operation at a $70 \%$ capacity factor.

d The coal is assumed to have a calorific value of $11,600 \mathrm{Btu} / \mathrm{lb}$ (typical).

e Swanson et al. (1976) provide coal trace element data. 

TABLE A.1.3 Calculated Annual Trace Element Emissions ${ }^{\text {a,b }}$ from a New, $^{\text {a }}$
Modern, 500-MWe Power Plant
${ }^{c}$ Firing U.S. Ohio Bituminous Coal

\begin{tabular}{|c|c|c|c|c|c|c|}
\hline Element & $\begin{array}{c}\text { Typical } \\
\text { Content } \\
(\mathrm{ppm})^{\mathrm{e}}\end{array}$ & $\begin{array}{c}\text { Calculated } \\
\text { Emissions } \\
\text { Based on } \\
\text { Typical } \\
\text { Content } \\
\text { (TPY) } \\
\end{array}$ & $\begin{array}{c}\text { Typical } \\
\text { Content } \\
+2 \text { S.D. } \\
\text { (ppm) }\end{array}$ & $\begin{array}{c}\text { Calculated } \\
\text { Emissions } \\
\text { Based on } \\
\text { Typical } \\
\text { Content } \\
\text { + } 2 \text { S.D. } \\
\text { (TPY) }\end{array}$ & $\begin{array}{c}\text { Maximum } \\
\text { Content } \\
(\mathrm{ppm})^{\mathrm{e}}\end{array}$ & $\begin{array}{c}\text { Calculated } \\
\text { Emissions } \\
\text { Based on } \\
\text { Maximum } \\
\text { Content } \\
\text { (TPY) }\end{array}$ \\
\hline $\mathrm{Sb}$ & 0.8 & 0.002 & 3.8 & 0.01 & 7.2 & 0.02 \\
\hline As & 15 & 0.45 & 49 & 1.47 & 78 & 2.36 \\
\hline $\mathrm{Be}$ & 1.8 & 0.04 & 3.8 & 0.08 & 5.0 & 0.11 \\
\hline $\mathrm{Cd}$ & 0.69 & 0.02 & 1.73 & 0.05 & 2.49 & 0.07 \\
\hline $\mathrm{Cl}$ & 264 & 28.6 & 552 & 59.8 & 580 & 62.8 \\
\hline $\mathrm{Cr}$ & 17 & 0.18 & 39 & 0.41 & 50 & 0.54 \\
\hline Co & 3.2 & 0.04 & 7.0 & 0.09 & 10 & 0.13 \\
\hline $\mathbf{F}$ & 86 & 27.9 & 178 & 57.9 & 230 & 74.7 \\
\hline $\mathrm{Pb}$ & 14.3 & 0.28 & 32.9 & 0.64 & 46.7 & 0.91 \\
\hline $\mathrm{Mn}$ & 54 & 1.17 & 110 & 2.38 & 130 & 2.82 \\
\hline $\mathrm{Hg}$ & 0.20 & 0.19 & 0.50 & 0.48 & 1.10 & 1.06 \\
\hline $\mathrm{Ni}$ & 9.8 & 0.04 & 19.4 & 0.08 & 20 & 0.09 \\
\hline $\mathbf{P}$ & 516 & 0.56 & 1,200 & 1.30 & 1,200 & 1.30 \\
\hline $\mathrm{Se}$ & 6.1 & 0.95 & 41.1 & 6.4 & 150 & 23.4 \\
\hline Th & 5.5 & 0.02 & 12.7 & 0.05 & 19.8 & 0.08 \\
\hline $\mathrm{U}$ & 0.9 & 0.01 & 2.3 & 0.02 & 3.7 & 0.05 \\
\hline Total & & 60.452 & & 131.16 & & 170.44 \\
\hline
\end{tabular}

a Bignoli (1989) provides several estimates of the quantity of elements expected to be mobilized in the EEC in the future from new PCF power plants.

b Szpunar, C.B., preliminary assessment results in progress, Argonne National Laboratory, Argonne, Illinois; these projections are based on current scientific thought about ele nent partitioning during coal firing and additional unpublished estimates of the quanicy of elements expected to be mobilized in the future from new PCF power plants.

c Hypothetical, new, modern, stringently regulated plant; particulate capture assumed to be $99.8 \%$; compliance FGD, although unspecified as to type; and operation at a $70 \%$ capacity factor.

$\mathrm{d}$ The coal is assumed to have a calorific value of $12,830 \mathrm{Btu} / \mathrm{b}$ (typical).

e Swanson et al. (1976) provide coal trace element data. 
TABLE A.1.4 Calculated Annual Trace Element Emissions ${ }^{\text {a,b }}$ from a New,
Modern, 500-MWe Power Plant ${ }^{c}$ Firing U.S. Tennessee Bituminous Coal

\begin{tabular}{|c|c|c|c|c|c|c|}
\hline Element & $\begin{array}{l}\text { Typical } \\
\text { Content } \\
(\mathrm{ppm})^{\mathrm{e}}\end{array}$ & $\begin{array}{c}\text { Calculated } \\
\text { Emissions } \\
\text { Based on } \\
\text { Typical } \\
\text { Content } \\
\text { (TPY) }\end{array}$ & $\begin{array}{c}\text { Typical } \\
\text { Content } \\
+2 \text { S.D. } \\
\text { (ppm) }\end{array}$ & $\begin{array}{c}\text { Calculated } \\
\text { Emissions } \\
\text { Based on } \\
\text { Typical } \\
\text { Content } \\
+2 \text { S.D. } \\
\text { (TPY) }\end{array}$ & $\begin{array}{c}\text { Maximum } \\
\text { Content } \\
\text { (ppm) }\end{array}$ & $\begin{array}{c}\text { Calculated } \\
\text { Emissions } \\
\text { Based on } \\
\text { Maximum } \\
\text { Content } \\
\text { (TPY) }\end{array}$ \\
\hline $\mathrm{Sb}$ & 1.2 & 0.03 & 2.8 & 0.07 & 3.7 & 0.09 \\
\hline As & 26 & 0.76 & 78 & 2.28 & 89 & 2.60 \\
\hline $\mathrm{Be}$ & 1.8 & 0.04 & 5.0 & 0.11 & 7.0 & 0.14 \\
\hline Cd & 0.74 & 0.02 & 1.72 & 0.05 & 1.97 & 0.06 \\
\hline $\mathrm{Cl}$ & 185 & 19.3 & 473 & 49.3 & 650 & 67.8 \\
\hline $\mathrm{Cr}$ & 16 & 0.17 & 50 & 0.53 & 70 & 0.73 \\
\hline Co & 3.3 & 0.04 & 7.5 & 0.09 & 10 & 0.12 \\
\hline$F$ & 80 & 25.0 & 196 & 61.2 & 200 & 62.4 \\
\hline $\mathrm{Pb}$ & 12.3 & 0.23 & 28.1 & 0.52 & 31.0 & 0.58 \\
\hline $\mathrm{Mn}$ & 37 & 0.77 & 93 & 1.94 & 130 & 2.71 \\
\hline $\mathrm{Hg}$ & 0.21 & 0.19 & 0.57 & 0.52 & 0.58 & 0.54 \\
\hline $\mathrm{Ni}$ & 12 & 0.05 & 32 & 0.13 & 50 & 0.21 \\
\hline $\mathrm{P}$ & 451 & 0.47 & 1,087 & 1.13 & 1,400 & 1.46 \\
\hline $\mathrm{Se}$ & 3.4 & 0.51 & 7.0 & 1.05 & 8.7 & 1.31 \\
\hline Th & 4.9 & 0.02 & 11.3 & 0.05 & 14.5 & 0.06 \\
\hline $\mathrm{U}$ & 1.6 & 0.02 & 5.0 & 0.06 & 6.7 & 0.08 \\
\hline Total & & 47.62 & & 119.03 & & 140.89 \\
\hline
\end{tabular}

a Bignoli (1989) provides several estimates of the quantity of elements expected to be mobilized in the EEC in the future from new PCF power plants.

b Szpunar, C.B., preliminary assessment results in progress, Argonne National

Laboratory, Argonne, Illinois; these projections are based on current scientific thought about element partitioning during coal firing and additional unpublished estimates of the quantity of elements expected to be mobilized in the future from new PCF power plants.

c Hypothetical, new, modern, stringently regulated plant; particulate capture assumed to be $99.8 \%$; compliance FGD, although unspecified as to type; and operation at a $70 \%$ capacity factor.

d The coal is assumed to have a calorific value of $13,320 \mathrm{Btu} / \mathrm{lb}$ (typical).

e Swanson et al. (1976) provide coal trace element data. 


\section{TABLE A.1.5 Calculated Annual Trace Element Emissions ${ }^{a, b}$ from a J Jew, Modern, 500-MWe Power Plant ${ }^{\mathrm{c}}$ Firing U.S. West Virginia Bit uminous Coal ${ }^{\text {d }}$}

\begin{tabular}{|c|c|c|c|c|c|c|}
\hline Element & $\begin{array}{l}\text { Typical } \\
\text { Content } \\
\text { (ppm) }^{\mathrm{e}}\end{array}$ & $\begin{array}{c}\text { Calculated } \\
\text { Emissions } \\
\text { Based on } \\
\text { Typical } \\
\text { Content } \\
\text { (TPY) } \\
\end{array}$ & $\begin{array}{c}\text { Typical } \\
\text { Content } \\
+2 \text { S.D. } \\
\text { (ppm) }\end{array}$ & $\begin{array}{c}\text { Calculated } \\
\text { Emissions } \\
\text { Based on } \\
\text { Typical } \\
\text { Content } \\
+2 \text { S.D. } \\
\text { (TPY) } \\
\end{array}$ & $\begin{array}{c}\text { Maximum } \\
\text { Content } \\
(\mathrm{ppm})^{\mathrm{e}}\end{array}$ & $\begin{array}{c}\text { Calculated } \\
\text { Emissions } \\
\text { Based on } \\
\text { Maximum } \\
\text { Content } \\
\text { (TPY) }\end{array}$ \\
\hline $\mathrm{Sb}$ & 1.4 & 0.05 & 7.6 & 0.16 & 223 & 0.56 \\
\hline As & 6 & 0.17 & 20 & 0.57 & 36 & 1.05 \\
\hline $\mathrm{Be}$ & 2.6 & 0.05 & 6.0 & 0.12 & 7.0 & 0.14 \\
\hline $\mathrm{Cd}$ & 0.08 & 0.002 & 0.22 & 0.006 & 0.48 & 0.01 \\
\hline $\mathrm{Cl}$ & 123 & 12.8 & 381 & 39.6 & 950 & 98.5 \\
\hline $\mathrm{Cr}$ & 19 & 0.20 & 49 & 0.52 & 70 & 0.73 \\
\hline Co & 7.4 & 0.09 & 15.6 & 0.19 & 20 & 0.25 \\
\hline $\mathbf{F}$ & 64 & 19.9 & 232 & 72.3 & 586 & 182 \\
\hline $\mathrm{Pb}$ & 14.7 & 0.27 & 34.9 & 0.64 & 58.2 & 1.09 \\
\hline Mn & 32 & 0.66 & 194 & 4.00 & 580 & 12.0 \\
\hline $\mathrm{Hg}$ & 0.09 & 0.08 & 0.23 & 0.20 & 0.35 & 0.32 \\
\hline $\mathrm{Ni}$ & 16 & 0.07 & 46 & 0.20 & 100 & 0.41 \\
\hline $\mathbf{P}$ & 56 & 0.06 & 172 & 0.18 & 420 & 0.44 \\
\hline Se & 5.1 & 0.76 & 10.1 & 1.50 & 11.0 & 1.64 \\
\hline $\mathrm{Th}$ & 5.4 & 0.02 & 11.2 & 0.04 & 15.4 & 0.06 \\
\hline $\mathrm{U}$ & 1.3 & 0.02 & 2.5 & 0.04 & 2.8 & 0.03 \\
\hline Total & & 35.182 & & 120.266 & & 299.23 \\
\hline
\end{tabular}

a Bignoli (1989) provides several estimates of the quantity of elements expected to be mobilized in the EEC in the future from new PCF power plants.

b Szpunar, C.B., preliminary assessment results in progress, Argonne National Laboratory, Argonne, Illinois; these projections are based on current scientific thought about element partitioning during coal firing and additional unpublished estimates of the quantity of elements expected to be mobilized in the future from new PCF power plants.

c Hypothetical, new, modern, stringently regulated plant; particulate capture assumed to be $99.8 \%$; compliance FGD, although unspecified as to type; and operation at a $70 \%$ capacity factor.

d The coal is assumed to have a calorific value of $13,390 \mathrm{Btu} / \mathrm{b}$ (typical).

e Swanson et al. (1976) provide coal trace element data. 
TABLE A.1.6 Calculated Annual Trace Element Emissions ${ }^{\text {a,b }}$ from a New, Modern, 500-MWe Power Plant ${ }^{c}$ Firing U.S. Virginia Bituminous Coal ${ }^{d}$

\begin{tabular}{|c|c|c|c|c|c|c|}
\hline Element & $\begin{array}{l}\text { Typicial } \\
\text { Content } \\
\text { (ppm) }^{\mathrm{e}}\end{array}$ & $\begin{array}{c}\text { Calculated } \\
\text { Emissions } \\
\text { Based on } \\
\text { Typical } \\
\text { Content } \\
\text { (TPY) }\end{array}$ & $\begin{array}{c}\text { Typical } \\
\text { Content } \\
+2 \text { S.D. } \\
(\text { ppn })\end{array}$ & $\begin{array}{c}\text { Calculated } \\
\text { Emissions } \\
\text { Based on } \\
\text { Typical } \\
\text { Content } \\
\text { + } 2 \text { S.D. } \\
\text { (TPY) }\end{array}$ & $\begin{array}{l}\text { Maximum } \\
\text { Content } \\
(\text { ppm })^{\mathrm{e}}\end{array}$ & $\begin{array}{c}\text { Calculated } \\
\text { Emissions } \\
\text { Based on } \\
\text { Maximum } \\
\text { Content } \\
\text { (TPY) }\end{array}$ \\
\hline $\mathrm{Sb}$ & 1.6 & 0.04 & 11.6 & 0.29 & 34.6 & 0.81 \\
\hline As & 18 & 0.49 & 60 & 1.63 & 80 & 2.19 \\
\hline $\mathrm{Be}$ & 1.3 & 0.02 & 3.3 & 0.05 & 7.0 & 0.14 \\
\hline $\mathrm{Cd}$ & 0.06 & 0.002 & 0.12 & 0.004 & 0.12 & 0.003 \\
\hline $\mathrm{Cl}$ & 77 & 7.54 & 171 & 16.7 & 260 & 25.4 \\
\hline $\mathrm{Cr}$ & 10 & 0.10 & 32 & 0.32 & 70 & 0.68 \\
\hline Co & 5.3 & 0.06 & 9.7 & 0.11 & 10 & 0.12 \\
\hline$F$ & 40 & 11.8 & 98 & 28.8 & 145 & 42.6 \\
\hline $\mathrm{Pb}$ & 6.6 & 0.12 & 26.4 & 0.48 & 65.6 & 1.16 \\
\hline $\mathbf{M n}$ & 33 & 0.65 & 103 & 2.03 & 150 & 2.94 \\
\hline $\mathrm{Hg}$ & 0.11 & 0.10 & 0.31 & 0.28 & 0.42 & 0.36 \\
\hline $\mathrm{Ni}$ & 9 & 0.03 & 23 & 0.08 & 50 & 0.20 \\
\hline $\mathbf{P}$ & 94 & 0.09 & 434 & 0.42 & 740 & 0.72 \\
\hline Se & 1.9 & 0.27 & 4.7 & 0.67 & 6.7 & 0.94 \\
\hline Th & 3.4 & 0.01 & 5.2 & 0.02 & 7.0 & 0.03 \\
\hline U & 1.0 & 0.01 & 2.0 & 0.02 & 2.1 & 0.02 \\
\hline Total & & 21.332 & & 51.904 & & 78.313 \\
\hline
\end{tabular}

a Bignoli (1989) provides several estimates of the quantity of elements expected to be mobilized in the EEC in the future from new PCF power plants.

b Szpunar, C.B., preliminary assessment results in progress, Argonne National Laboratory, Argonne, Illinois; these projections are based on current scientific thought about element partitioning during coal firing and additional unpublished estimates of the quantity of elements expected to be mobilized in the future from new PCF power plants.

c Hypothetical, new, modern, stringently regulated plant; particulate capture assumed to be 99.8\%; compliance FGD, although unspecified as to type; and operation at a $70 \%$ capacity factor.

d The coal is assumed to have a calorific value of $14,190 \mathrm{Btu} / \mathrm{lb}$ (typical).

e Swanson et al. (1976) provide coal trace element data. 
TABLE A.2 Calculated Annual Trace Element Emissiong ${ }^{a, b}$ from a New, Modern, 500-MWe Power Plant ${ }^{\mathrm{c}}$ Firing U.S. Interior Bituminous Coal ${ }^{\mathrm{d}}$

\begin{tabular}{|c|c|c|c|c|}
\hline Element & $\begin{array}{c}\text { Typical } \\
\text { Content } \\
(\mathrm{ppm})^{\mathrm{e}}\end{array}$ & $\begin{array}{c}\text { Calculated } \\
\text { Emissions } \\
\text { Based on } \\
\text { Typical } \\
\text { Content } \\
\text { (TPY) }\end{array}$ & $\begin{array}{c}\text { Maximum } \\
\text { Content } \\
(\mathrm{ppm})^{\mathrm{f}}\end{array}$ & $\begin{array}{c}\text { Calculated } \\
\text { Emissions } \\
\text { Based on } \\
\text { Maximum } \\
\text { Content } \\
\text { (TPY) } \\
\end{array}$ \\
\hline $\mathrm{Sb}$ & 1.7 & 0.05 & 16 & 0.46 \\
\hline As & 21 & 0.70 & 240 & 8.06 \\
\hline $\mathrm{Be}$ & 3 & 0.07 & 18 & 0.43 \\
\hline $\mathrm{Cd}$ & 7.1 & 0.23 & 170 & 5.50 \\
\hline $\mathrm{Cl}$ & 485 & 58.2 & $5,400^{g, h}$ & 648 \\
\hline $\mathrm{Cr}$ & 15 & 0.18 & 200 & 2.40 \\
\hline Co & 7 & 0.10 & 500 & 7.20 \\
\hline $\mathbf{F}$ & 71 & 25.6 & 630 & 227 \\
\hline $\mathrm{Pb}$ & 55 & 1.19 & 590 & 12.7 \\
\hline Mn & 138 & 3.31 & 1,100 & 26.4 \\
\hline $\mathrm{Hg}$ & 0.14 & 0.15 & 1.5 & 1.60 \\
\hline $\mathrm{Ni}$ & 30 & 0.14 & 580 & 2.78 \\
\hline $\mathbf{P}$ & 365 & 0.44 & $1,430^{g, h, i}$ & 1.72 \\
\hline $\mathrm{Se}$ & 4.6 & 0.79 & 75 & 13.0 \\
\hline $\mathrm{Th}$ & 5.2 & 0.02 & 79 & 0.38 \\
\hline $\mathbf{U}$ & 3.3 & 0.05 & 59 & 0.85 \\
\hline Total & & 91.22 & & 958.48 \\
\hline
\end{tabular}

a Bignoli (1989) provides several estimates of the quantity of elements expected to be mobilized in the EEC in the future from new PCF power plants.

b Szpunar, C.B., preliminary assessment results in progress, Argonne National Laboratory, Argonne, Illinois; these projections are based on current scientific thought about element partitioning during coal firing and additional unpublished estimates of the quantity of elements expected to be mobilized in the future from new PCF power plants.

c Hypothetical, new, modern, stringently regulated plant; particulate capture assumed to be $99.8 \%$; compliance FGD, although unspecified as to type; and operation at a $70 \%$ capacity factor.

d The coal is assumed to have a calorific value of 11,580 Btu/lb (typical).

e Swanson et al. (1976) provide coal trace element data; Illinois coals are excluded.

f Zubovic et al. (1979); Illinois coals are included.

B Gluskoter et al. (1977).

h Illinois coals only.

i Abernethy and Gibson (1963). 
TABLE A.2.1 Calculated Annual Trace Element Emissions ${ }^{a, b}$ from a New, Modern, 500-MWe Power Plant ${ }^{c}$ Firing U.S. Illinois Bituminous Coal ${ }^{d}$

\begin{tabular}{|c|c|c|c|c|c|c|}
\hline Element & $\begin{array}{l}\text { Typical } \\
\text { Content } \\
\text { (ppm) })^{\mathrm{e}}\end{array}$ & $\begin{array}{c}\text { Calculated } \\
\text { Emissions } \\
\text { Based on } \\
\text { Typical } \\
\text { Content } \\
\text { (TPY) } \\
\end{array}$ & $\begin{array}{c}\text { Typical } \\
\text { Content } \\
+2 \text { S.D. } \\
\text { (ppm) }\end{array}$ & $\begin{array}{c}\text { Calculated } \\
\text { Emissions } \\
\text { Based on } \\
\text { Typical } \\
\text { Content } \\
\text { + } 2 \text { S.D. } \\
\text { (TYY) } \\
\end{array}$ & $\begin{array}{c}\text { Maximum } \\
\text { Content } \\
(\mathrm{ppm})^{\mathrm{e}}\end{array}$ & $\begin{array}{c}\text { Calculated } \\
\text { Emissions } \\
\text { Based on } \\
\text { Maximum } \\
\text { Content } \\
\text { (TPY) }\end{array}$ \\
\hline $\mathrm{Sb}$ & 1.3 & 0.03 & 5.3 & 0.12 & 11.0 & 0.29 \\
\hline As & 4.1 & 0.12 & 13.7 & 0.40 & 24.8 & 0.76 \\
\hline $\mathrm{Be}$ & 1.1 & 0.02 & 2.3 & 0.05 & 2.3 & 0.05 \\
\hline $\mathrm{Cd}$ & 0.50 & 0.01 & 4.18 & 0.12 & 10.4 & 0.31 \\
\hline $\mathrm{Cl}$ & 1,228 & 134 & 4,182 & 456 & 4,768 & 521 \\
\hline $\mathrm{Cr}$ & 37.3 & 0.41 & 168.1 & 1.85 & 416 & 4.55 \\
\hline Co & 5.4 & 0.07 & 16.4 & 0.21 & 25.5 & 0.33 \\
\hline $\mathbf{F}$ & 317 & 104 & 2,109 & 693 & 5,387 & 1,767 \\
\hline $\mathrm{Pb}$ & 12.2 & 0.24 & 53.8 & 1.06 & 96.3 & 1.90 \\
\hline Mn & 81 & 1.77 & 279 & 6.10 & 596 & 13.0 \\
\hline $\mathrm{Hg}$ & 0.10 & 0.16 & 0.42 & 0.42 & 0.62 & 0.60 \\
\hline $\mathrm{Ni}$ & 22.9 & 0.10 & 69.1 & 0.30 & 132 & 0.58 \\
\hline $\mathbf{P}$ & 187 & 0.20 & 1,687 & 1.80 & 4,820 & 5.27 \\
\hline $\mathrm{Se}$ & 4.0 & 0.63 & 20.4 & 3.21 & 53.9 & 8.49 \\
\hline Th & 3.9 & 0.02 & 16.1 & 0.08 & 26.4 & 0.11 \\
\hline $\mathrm{U}$ & 3.2 & 0.04 & 18.6 & 0.23 & 41.6 & 0.55 \\
\hline Total & & 241.82 & & $1,164.95$ & & $2,324.79$ \\
\hline
\end{tabular}

a Bignoli (1989) provides several estimates of the quantity of eleme t" expected to be mobilized in the EEC in the future from new PCF power plants.

b Szpunar, C.B., preliminary assessment results in progress, Argonne National Laboratory, Argonne, Illinois; these projections are based on current scientific thought about element partitioning during coal firing and additional cinpublished estimates of the quantity of elements expected to be mobilized in the future from new PCF power plants.

c Hypothetical, new, modern, stringently regulated plant assuming particulate capture efficiency of $99.8 \%$; compliance FGD, al ${ }^{4}$ hough unspecified as to type; and operation at a $70 \%$ capacity factor.

$\mathrm{d}$ The coal is assumed to have a calorific value of $12,700 \mathrm{Btu} / \mathrm{lb}$ (typical).

e Gluskoter et al. (1977) provide coal trace element data. 
TABLE A.2.2 Calculated Annual Trace Element Emissions ${ }^{a, b}$ from a New, Modern, 500-MWe Power Plant ${ }^{c}$ Firing U.S. Iowa Bituminous Coal ${ }^{\mathrm{d}}$

\begin{tabular}{|c|c|c|c|c|c|c|}
\hline Element & $\begin{array}{l}\text { Typical } \\
\text { Content } \\
\text { (ppm) }^{\mathrm{e}}\end{array}$ & $\begin{array}{c}\text { Calculated } \\
\text { Emissions } \\
\text { Based on } \\
\text { Typical } \\
\text { Content } \\
\text { (TPY) }\end{array}$ & $\begin{array}{c}\text { Typical } \\
\text { Content } \\
+2 \text { S.D. } \\
\text { (ppm) }\end{array}$ & $\begin{array}{c}\text { Calculated } \\
\text { Emissions } \\
\text { Based on } \\
\text { Typical } \\
\text { Content } \\
+2 \text { S.D. } \\
\text { (TPY) }\end{array}$ & $\begin{array}{c}\text { Maximum } \\
\text { Content } \\
\text { (ppm) }^{\mathrm{e}}\end{array}$ & $\begin{array}{c}\text { Calculated } \\
\text { Emissions } \\
\text { Based on } \\
\text { Maximum } \\
\text { Content } \\
\text { (TPY) }\end{array}$ \\
\hline $\mathrm{Sb}$ & 3.0 & 0.10 & 11.6 & 0.39 & 16.0 & 0.56 \\
\hline As & 35 & 1.43 & 131 & 5.35 & 240 & 9.80 \\
\hline $\mathrm{Be}$ & 2.3 & 0.07 & 4.1 & 0.12 & 5.0 & 0.15 \\
\hline $\mathrm{Cd}$ & 11.4 & 0.45 & 58.8 & 2.32 & 99.7 & 3.93 \\
\hline $\mathrm{Cl}$ & 477 & 69.6 & 829 & 121 & 920 & 134 \\
\hline $\mathrm{Cr}$ & 20 & 0.29 & 48 & 0.70 & 70 & 1.02 \\
\hline Co & 18 & 0.31 & 60 & 1.03 & 100 & 1.75 \\
\hline $\mathbf{F}$ & 71 & 31.2 & 151 & 66.3 & 160 & 69.9 \\
\hline $\mathrm{Pb}$ & 64.9 & 1.70 & 177 & 4.65 & 255 & 6.70 \\
\hline $\mathbf{M n}$ & 225 & 6.56 & 601 & 17.5 & 780 & 22.8 \\
\hline $\mathrm{Hg}$ & 0.16 & 0.21 & 0.34 & 0.45 & 0.44 & 0.57 \\
\hline $\mathrm{Ni}$ & 52 & 0.30 & 148 & 0.85 & 200 & 1.17 \\
\hline $\mathbf{P}$ & 1,018 & 1.48 & 1,750 & 2.55 & 2,000 & 2.92 \\
\hline Se & 9.1 & 1.91 & 35.9 & 7.55 & 75.0 & 15.8 \\
\hline Th & 10.3 & 0.06 & 36.1 . & 0.21 & 52.3 & 0.30 \\
\hline $\mathbf{U}$ & 8.1 & 0.14 & 28.1 & 0.48 & 42.9 & 0.75 \\
\hline Total & & 115.81 & & 231.45 & & 272.12 \\
\hline
\end{tabular}

a Bignoli (1989) provides several estimates of the quantity of elements expected to be mobilized in the EEC in the future from new PCF power plants.

b Szpunar, C.B., preliminary assessment results in progress, Argonne National Laboratory, Argonne, nlinois; these projections are based on current scientific thought about element partitioning during coal firing and additional unpublished estimates of the quantity of elements expected to be mobilized in the future from new PCF power plants.

c Hypothetical, new, modern, stringently regulated plant assuming particulate capture efficiency of $99.8 \%$; compliance FGD, although unspecified as to type; and operation at a $70 \%$ capacity factor.

d The coal is assumed to have a calorific value of $9,520 \mathrm{Btu} / \mathrm{lb}$ (typical).

e Swanson et al. (1976) provide coal trace element data. 
TABLE A.2.3 Calculated Annual Trace Element Emissions ${ }^{\text {a,b }}$ from a New, Modern, 500-MWe Power Plant ${ }^{c}$ Firing U.S. Missouri Bituminous Coal ${ }^{d}$

\begin{tabular}{|c|c|c|c|c|c|c|}
\hline Element & $\begin{array}{l}\text { Typical } \\
\text { Content } \\
(p p m)^{e}\end{array}$ & $\begin{array}{c}\text { Calculated } \\
\text { Emissions } \\
\text { Based on } \\
\text { Typical } \\
\text { Content } \\
\text { (TPY) }\end{array}$ & $\begin{array}{c}\text { Typical } \\
\text { Content } \\
+2 \text { S.D. } \\
\text { (ppm) }\end{array}$ & $\begin{array}{c}\text { Calculated } \\
\text { Emissions } \\
\text { Based on } \\
\text { Typical } \\
\text { Content } \\
+2 \text { S.D. } \\
\text { (T'PY) }\end{array}$ & $\begin{array}{c}\text { Maximum } \\
\text { Content } \\
(\mathrm{ppm})^{\mathrm{e}}\end{array}$ & $\begin{array}{c}\text { Calculated } \\
\text { Emissions } \\
\text { Based on } \\
\text { Maximum } \\
\text { Content } \\
\text { (TPY) }\end{array}$ \\
\hline $\mathrm{Sb}$ & 2.7 & 0.08 & 8.3 & 0.25 & 12.0 & 0.36 \\
\hline As & 16 & 0.56 & 42 & 1.47 & 60 & 2.11 \\
\hline $\mathrm{Be}$ & 1.6 & 0.04 & 2.6 & 0.06 & 3.0 & 0.07 \\
\hline $\mathrm{Cd}$ & 9.0 & 0.30 & 44.6 & 1.49 & 77.1 & 2.61 \\
\hline $\mathrm{Cl}$ & 172 & 21.6 & 332 & 41.7 & 360 & 45.1 \\
\hline $\mathrm{Cr}$ & 11 & 0.14 & 25 & 0.32 & 30 & 0.38 \\
\hline Co & 6 & 0.09 & 14 & 0.21 & 15 & 0.23 \\
\hline $\mathbf{F}$ & 67 & 25.2 & 147 & 55.2 & 170 & 63.9 \\
\hline $\mathrm{Pb}$ & 76.0 & 1.71 & 222 & 5.00 & 283 & 6.38 \\
\hline Mn & 266 & 6.67 & 1,880 & 47.1 & 4,400 & 110 \\
\hline $\mathrm{Hg}$ & 0.13 & 0.14 & 0.23 & 0.25 & 0.29 & 0.32 \\
\hline $\mathrm{Ni}$ & 22 & 0.11 & 46 & 0.23 & 50 & 0.25 \\
\hline $\mathrm{P}$ & 204 & 0.26 & 654 & 0.83 & 780 & 0.98 \\
\hline $\mathrm{Se}$ & 6.9 & 1.24 & 16.7 & 3.00 & 22.0 & 3.97 \\
\hline Th & 7.7 & 0.04 & 35.1 & 0.18 & 79.4 & 0.40 \\
\hline $\mathrm{U}$ & 3.4 & 0.05 & 11.8 & 0.17 & 19.3 & 0.29 \\
\hline Total & & 58.23 & & 157.46 & & 237.35 \\
\hline
\end{tabular}

a Bignoli (1989) provides several estimates of the quantity of elements expected to be mobilized in the EEC in the future from new PCF power plants.

b Szpunar, C.B., preliminary assessment results in progress, Argonne National Laboratory, Argonne, Illinois; these projections are based on current scientific thought about element partitioning during coal firing and additional unpublished estimates of the quantity of elements expected to be mobilized in the future from new PCF power plants.

c Hypothetical, new, modern, stringently regulated plant assuming particulate capture efficiency of $99.8 \%$; compliance FGD, although unspecified as to type; and operation at a $70 \%$ capacity factor.

d The coal is assumed to have a calorific value of $11,080 \mathrm{Btu} / \mathrm{lb}$ (typical).

e Swanson et al. (1976) provide coal trace element data. 
TABLE A.2.4 Calculated Annual Trace Element Emissions ${ }^{\text {a,b }}$ from a New,
Modern, 500-MWe Power Plant ${ }^{c}$ Firing U.S. Oklahoma Bituminous Coal

\begin{tabular}{|c|c|c|c|c|c|c|}
\hline Element & $\begin{array}{l}\text { Typical } \\
\text { Content } \\
(\text { ppm })^{\mathrm{e}}\end{array}$ & $\begin{array}{c}\text { Calculated } \\
\text { Emissions } \\
\text { Based on } \\
\text { Typical } \\
\text { Content } \\
\text { (TPY) }\end{array}$ & $\begin{array}{c}\text { Typical } \\
\text { Content } \\
+2 \text { S.D. } \\
\text { (ppm) }\end{array}$ & $\begin{array}{c}\text { Calculated } \\
\text { Emissions } \\
\text { Based on } \\
\text { Typical } \\
\text { Content } \\
\text { + } 2 \text { S.D. } \\
\text { (TPY) }\end{array}$ & $\begin{array}{c}\text { Maximum } \\
\text { Content } \\
\text { (ppm) }\end{array}$ & $\begin{array}{c}\text { Calculated } \\
\text { Emissions } \\
\text { Based on } \\
\text { Maximum } \\
\text { Content } \\
\text { (TFY) }\end{array}$ \\
\hline $\mathbf{S b}$ & 0.5 & 0.01 & 1.7 & 0.04 & 2.7 & 0.07 \\
\hline As & 14 & 0.40 & 44 & 1.25 & 60 & 1.70 \\
\hline $\mathrm{Be}$ & 0.5 & 0.01 & 1.5 & 0.03 & 1.5 & 6.03 \\
\hline Cd & 0.13 & 0.004 & $0.2 \delta$ & 0.006 & 0.3 & 0.008 \\
\hline $\mathrm{Cl}$ & 210 & 21.3 & 472 & 47.6 & 530 & 53.4 \\
\hline $\mathrm{Cr}$ & 14 & 0.14 & 38 & 0.39 & 50 & 0.51 \\
\hline Co & 6 & 0.07 & 14 & 0.17 & 15 & 0.18 \\
\hline $\mathbf{F}$ & 57 & 17.3 & 129 & 39.3 & 130 & 39.6 \\
\hline $\mathrm{Pb}$ & 5.0 & 0.09 & 13.4 & 0.24 & 19.2 & 0.35 \\
\hline Mn & 116 & 2.35 & 354 & 7.17 & 410 & 8.31 \\
\hline $\mathrm{Hg}$ & 0.16 & 0.14 & 0.58 & 0.52 & 0.83 & 0.75 \\
\hline $\mathrm{Ni}$ & 14 & 0.06 & 36 & 0.14 & 50 & 0.20 \\
\hline $\mathbf{P}$ & 459 & 0.46 & 1,017 & 1.03 & 1,100 & 1.11 \\
\hline $\mathrm{Se}$ & 2.0 & 0.29 & 6.8 & 0.99 & 11.0 & 1.60 \\
\hline Th & 5.2 & 0.02 & 16.2 & 0.07 & 26.1 & 0.11 \\
\hline $\mathrm{U}$ & 1.7 & 0.02 & 7.5 & 0.09 & 12.9 & 0.16 \\
\hline Total & & 42.664 & & 99.036 & & 108.088 \\
\hline
\end{tabular}

a Bigncli (1989) provides several estimates of the quantity of elements expected to be mobilized in the EEC in the future from new PCF power plants.

b Szpunar, C.B., preliminary assessment results in progress, Argonne National Laboratory, Argonne, Mlinois; these projections are based on current scientific thought about element partitioning during coal firing and additional unpublished estimates of the quantity of elements expected to be mobilized in the future from new PCF power plants.

c Hypothetical, new, modern, stringently regulated plant assuming particulate capture efficiency of $99.8 \%$; compliance FGD, although unspecified as to type; and operation at a $70 \%$ capacity factor.

d The coal is assumed to have a calorific value of $13,710 \mathrm{Btu} / \mathrm{lb}$ (typical).

e Swanson et al. (1976) provide coal trace element data. 
TABLE A.2.5 Calculated Annu\&l Trace Element Emissions ${ }^{a, b}$ from a New, Modern, 500-MWe Power Plant ${ }^{c}$ Firing U.S. Indiana Bituminous Coal ${ }^{d}$

\begin{tabular}{|c|c|c|c|c|c|c|}
\hline Element & $\begin{array}{c}\text { Typical } \\
\text { Content } \\
\text { (ppm) }^{\mathrm{e}}\end{array}$ & $\begin{array}{c}\text { Calculated } \\
\text { Emissions } \\
\text { Based on } \\
\text { Typical } \\
\text { Content } \\
\text { (TPY) }\end{array}$ & $\begin{array}{c}\text { Typical } \\
\text { Content } \\
+2 \text { S.D. } \\
\text { (ppm) }\end{array}$ & $\begin{array}{c}\text { Calculated } \\
\text { Emissions } \\
\text { Based on } \\
\text { Typical } \\
\text { Content } \\
\text { + } 2 \text { S.D. } \\
\text { (TPY) }\end{array}$ & $\begin{array}{c}\text { Maximum } \\
\text { Content } \\
\text { (ppm) }^{\mathrm{e}}\end{array}$ & $\begin{array}{c}\text { Calculated } \\
\text { Emissions } \\
\text { Based on } \\
\text { Maximum } \\
\text { Content } \\
\text { (TPY) }\end{array}$ \\
\hline Sb & 1.4 & 0.04 & 4.4 & 0.13 & 6.9 & 0.20 \\
\hline As & 10 & 0.33 & 28 & 0.94 & 40 & 1.34 \\
\hline $\mathrm{Be}$ & 2.1 & 0.05 & 4.1 & 0.10 & 5.0 & 0.12 \\
\hline $\mathrm{Cd}$ & 0.43 & 0.01 & 1.75 & 0.06 & 3.02 & 0.10 \\
\hline Cl & 142 & 1.6 .9 & 312 & 37.2 & 440 & 52.5 \\
\hline $\mathrm{Cr}$ & 12 & 0.14 & 24 & 0.29 & 30 & 0.36 \\
\hline Co & 3.5 & 0.05 & 9.1 & 0.13 & 10.0 & 0.14 \\
\hline $\mathbf{F}$ & 60 & 21.48 & 108 & 38.7 & 135 & 48.3 \\
\hline $\mathbf{P b}$ & 12.5 & 0.27 & $\mathbf{3 3 . 5}$ & 0.72 & 41.3 & 0.89 \\
\hline Mn & 59 & 1.41 & 203 & 4.84 & 360 & 8.59 \\
\hline $\mathbf{H g}$ & 0.11 & 0.12 & 0.27 & 0.29 & 0.44 & 0.47 \\
\hline $\mathrm{Ni}$ & 16 & 0.08 & 42 & 0.20 & 50 & 0.24 \\
\hline $\mathbf{P}$ & 80 & 0.09 & 224 & 0.26 & 380 & 0.45 \\
\hline Se & 4.4 & 0.76 & 11.4 & 1.96 & 13.0 & 2.23 \\
\hline Th & 4.4 & 0.02 & 10.6 & 0.05 & 17.9 & 0.08 \\
\hline $\mathbf{U}$ & 2.2 & 0.03 & 8.8 & 0.13 & 16.6 & 0.24 \\
\hline Total & & 41.78 & & 86.00 & & 116.25 \\
\hline
\end{tabular}

a Bignoli (1989) provides several estimates of the quantity of elements expected to be mobilized in the EEC in the future from new PCF power plants.

b Szpunar, C.B., preliminary assessment results in progress, Argonne National Laboratory, Argonne, Illinois; these projections are based on current scientific thought about element partitioning during coal firing and additional unpublished estimates of the quantity of elements expected to be mobilized in the future from new PCF power plants.

c Hypothetical, new, modern, stringently regulated plant assuming particulate capture efficiency of $99.8 \%$; compliance FGD, although unspecified as to type; and operation at a $70 \%$ capacity factor.

d The coal is assumed to have a calorific value of $11,640 \mathrm{Btu} / \mathrm{lb}$ (typical).

e Swanson et al. (1976) provide coal trace element data. 
TABLE A.2.6 Calculated Annual Trace Element Emissions ${ }^{\text {a,b }}$ from a New, Modern, 500-MWe Power Plant ${ }^{\mathrm{c}}$ Firing U.S. Arkansas Bituminous Coal ${ }^{d}$

\begin{tabular}{|c|c|c|c|c|c|c|}
\hline Element & $\begin{array}{c}\text { Typical } \\
\text { Content } \\
\text { (ppm) }\end{array}$ & $\begin{array}{c}\text { Calculated } \\
\text { Emissions } \\
\text { Based on } \\
\text { Typical } \\
\text { Content } \\
\text { (TPY) } \\
\end{array}$ & $\begin{array}{c}\text { Typical } \\
\text { Content } \\
+2 \text { S.D. } \\
\text { (ppm) }\end{array}$ & $\begin{array}{c}\text { Calculated } \\
\text { Emissions } \\
\text { Based on } \\
\text { Typical } \\
\text { Content } \\
\text { + } 2 \text { S.D. } \\
\text { (TPY) } \\
\end{array}$ & $\begin{array}{c}\text { Maximum } \\
\text { Content } \\
(\mathrm{ppm})^{\mathrm{e}}\end{array}$ & $\begin{array}{c}\text { Calculated } \\
\text { Emissions } \\
\text { Based on } \\
\text { Maximum } \\
\text { Content } \\
\text { (TPY) }\end{array}$ \\
\hline $\mathrm{Sb}$ & 0.2 & 0.005 & 0.4 & 0.008 & 0.5 & 0.01 \\
\hline As & 17 & 0.48 & 73 & 2.04 & 120 & 3.36 \\
\hline $\mathrm{Be}$ & 0.4 & 0.008 & 0.7 & 0.01 & 0.7 & 0.01 \\
\hline $\mathrm{Cd}$ & 0.11 & 0.003 & 0.17 & 0.004 & 0.2 & 0.005 \\
\hline Cl & 64 & 6.40 & 118 & 11.8 & 120 & 12.0 \\
\hline $\mathrm{Cr}$ & 8 & 0.08 & 18 & 0.18 & 20 & 0.20 \\
\hline Co & 5 & 0.06 & 11 & 0.13 & 15 & 0.18 \\
\hline $\mathbf{F}$ & 56 & 16.8 & 112 & 33.6 & 120 & 36.0 \\
\hline $\mathrm{Pb}$ & 2.7 & 0.05 & 6.5 & 0.11 & 7.4 & 0.13 \\
\hline $\mathbf{M n}$ & 54 & 1.08 & 144 & 2.88 & 150 & 3.00 \\
\hline Hg & 0.14 & 0.12 & 0.48 & 0.42 & 0.59 & 0.52 \\
\hline $\mathrm{Ni}$ & 10 & 0.04 & 24 & 0.09 & 30 & 0.12 \\
\hline $\mathbf{P}$ & 82 & 0.08 & 180 & 0.18 & 210 & 0.21 \\
\hline $\mathrm{Se}$ & 1.5 & 0.22 & 3.3 & 0.47 & 3.3 & 0.47 \\
\hline Th & 3.0 & 0.01 & 3.0 & 0.01 & 3.0 & 0.01 \\
\hline $\mathbf{U}$ & 0.4 & 0.005 & 1.0 & 0.02 & 1.3 & 0.02 \\
\hline Total & & 25.441 & & 51.952 & & 56.254 \\
\hline
\end{tabular}

a Bignoli (1989) provides several estimates of the quantity of elements expected to be mobilized in the EEC in the future from new PCF power plants.

b Szpunar, C.B., preliminary assessment results in progress, Argonne National Laboratory, Argonne, Ilinois; these projections are based on current scientific thought about element partitioning during coal firing and additional unpublished estimates of the quantity of elements expected to be mobilized in the future from new PCF power plants.

c Hypothetical, new, modern, stringently regulated plant assuming particulate capture efficiency of $99.8 \%$; compliance FGD, although unspecified as to type; and operation at a $70 \%$ capacity factor.

d The coal is assumed to have a calorific value of $13,890 \mathrm{Btu} / \mathrm{b}$ (typical).

e Swanson et al. (1976) provide coal trace element data. 
TABLE A.3 Calculated Annual Trace Element Emissiong ${ }^{\text {a,b }}$ from a New, Modern, 500-MWe Power Plant ${ }^{\mathrm{c}}$ Firing U.S. Rocky Mountain Bituminous Coal ${ }^{\text {d }}$

\begin{tabular}{|c|c|c|c|c|}
\hline Element & $\begin{array}{c}\text { Typical } \\
\text { Content } \\
\text { (ppm) }\end{array}$ & $\begin{array}{c}\text { Calculated } \\
\text { Emissions } \\
\text { Based on } \\
\text { Typical } \\
\text { Content } \\
\text { (TPY) }\end{array}$ & $\underset{\text { Content }}{\text { Maximum }}$ & $\begin{array}{c}\text { Calculated } \\
\text { Emissions } \\
\text { Based on } \\
\text { Maximum } \\
\text { Content } \\
\text { (TPY) }\end{array}$ \\
\hline $\mathrm{Sb}$ & 0.4 & 0.01 & 7.3 & 0.23 \\
\hline As & 2 & 0.07 & 60 & 2.23 \\
\hline $\mathrm{Be}$ & 0.7 & 0.02 & 6.2 & 0.16 \\
\hline Cd & 0.5 & 0.02 & 0.99 & 0.04 \\
\hline Cl & 120 & 15.9 & $1,300^{g, h}$ & 172 \\
\hline $\mathrm{Cr}$ & 5 & 0.07 & 75 & 0.99 \\
\hline Co & 2 & 0.03 & 21 & 0.33 \\
\hline $\mathbf{F}$ & 70 & 27.8 & 940 & 375 \\
\hline $\mathrm{Pb}$ & 5.5 & 0.13 & 137 & 3.27 \\
\hline Mn & 36 & 0.95 & 590 & 15.6 \\
\hline $\mathrm{Hg}$ & 0.06 & 0.07 & 0.90 & 1.06 \\
\hline $\mathrm{Ni}$ & 3 & 0.02 & 340 & 1.80 \\
\hline $\mathbf{P}$ & 192 & 0.25 & $510^{\mathrm{g}, \mathrm{h}}$ & 0.68 \\
\hline $\mathrm{Se}$ & 1.6 & 0.30 & 13 & 2.48 \\
\hline Th & 3.6 & 0.02 & 18 & 0.10 \\
\hline $\mathbf{U}$ & 1.6 & 0.02 & 42 & 0.67 \\
\hline Total & & 45.68 & & 576.64 \\
\hline
\end{tabular}

a Bignoli (1989) provides several estimates of the quantity of elements expected to be mobilized in the EEC in the future from new PCF power plants.

b Szpunar, C.B., preliminary assessment results in progress, Argonne National Laboratory, Argonne, Illinois; these projections are based on current scientific thought about element partitioning during coal firing and additional unpublished estimates of the quantity of elements expected to be mobilized in the future from new PCF power plants.

c Hypothetical, new, modern, stringently regulated plant assuming particulate capture efficiency of $99.8 \%$; compliance FGD, although unspecified as to type; and operation at a $70 \%$ capacity factor.

d The coal is assumed to have a calorific value of $10,480 \mathrm{Btu} / \mathrm{lb}$ (typical).

e Swanson et al. (1976) provide coal trace element data.

f Zubovic et al. (1979).

B Gluskoter et al. (1977).

h Western coals; rank unspecified. 


\section{TABLE A.3.1 Calculated Annual Trace Element Emissions ${ }^{\text {a,b }}$ from a New, Modern, 500-MWe Power Plant ${ }^{\mathrm{c}}$ Firing U.S. North Park, Colorado, Bituminous Coal ${ }^{\mathrm{d}}$}

\begin{tabular}{|c|c|c|c|c|c|c|}
\hline Element & $\begin{array}{l}\text { Typical } \\
\text { Content } \\
(\mathrm{ppm})^{\mathrm{e}}\end{array}$ & $\begin{array}{c}\text { Calculated } \\
\text { Emissions } \\
\text { Based on } \\
\text { Typical } \\
\text { Content } \\
\text { (TPY) } \\
\end{array}$ & $\begin{array}{c}\text { Typical } \\
\text { Content } \\
+2 \text { S.D. } \\
\text { (ppm) }\end{array}$ & $\begin{array}{c}\text { Calculated } \\
\text { Emissions } \\
\text { Based on } \\
\text { Typical } \\
\text { Content } \\
\text { + } 2 \text { S.D. } \\
\text { (TPY) } \\
\end{array}$ & $\begin{array}{c}\text { Maximum } \\
\text { Content } \\
(\mathrm{ppm})^{\mathrm{e}}\end{array}$ & $\begin{array}{c}\text { Calculated } \\
\text { Emissions } \\
\text { Based on } \\
\text { Maximum } \\
\text { Content } \\
\text { (TPY) }\end{array}$ \\
\hline $\mathrm{Sb}$ & 0.2 & 0.007 & 0.6 & 0.02 & 0.9 & 0.03 \\
\hline As & 2 & 0.08 & 4 & 0.16 & 4 & 0.16 \\
\hline $\mathrm{Be}$ & 0.6 & 0.02 & 2.0 & 0.05 & 3.0 & 0.08 \\
\hline $\mathrm{Cd}$ & 0.1 & 0.004 & 0.5 & 0.02 & 0.9 & 0.03 \\
\hline $\mathrm{Cl}$ & 129 & 17.9 & 481 & 66.7 & 880 & 122 \\
\hline $\mathrm{Cr}$ & 11 & 0.15 & 43 & 0.60 & 70 & 0.97 \\
\hline Co & 2.4 & 0.04 & 7.4 & 0.13 & 10.0 & 0.17 \\
\hline $\mathrm{F}$ & 106 & 44.1 & 482 & 199 & 920 & 381 \\
\hline $\mathrm{Pb}$ & 4.9 & 0.12 & 14.3 & 0.36 & 22 & 0.55 \\
\hline $\mathrm{Mn}$ & 41 & 1.14 & 117 & 3.24 & 140 & 3.88 \\
\hline $\mathrm{Hg}$ & 0.05 & 0.06 & 0.13 & 0.16 & 0.21 & 0.26 \\
\hline $\mathrm{Ni}$ & 4 & 0.02 & 14 & 0.07 & 15 & 0.08 \\
\hline$P$ & 201 & 0.28 & 485 & 0.67 & 570 & 0.79 \\
\hline Se & 1.2 & 0.24 & 3.6 & 0.72 & 5.7 & 1.14 \\
\hline Th & 6.7 & 0.04 & 21.3 & 0.12 & 34.8 & 0.19 \\
\hline $\mathrm{U}$ & 4.1 & 0.07 & 15.7 & 0.26 & 23.7 & 0.39 \\
\hline Total & & 64.271 & & 272.28 & & 511.72 \\
\hline
\end{tabular}

a Bignoli (1989) provides several estimates of the quantity of elements expected to be mobilized in the EEC in the future from new PCF power plants.

b Szpunar, C.B., preliminary assessment results in progress, Argonne National Laboratory, Argonne, Illinois; these projections are based on current scientific thought about element partitioning during coal firing and additional unpublished estimates of the quantity of elements expected to be mobilized in the future from new PCF power plants.

c Hypothetical, new, modern, stringently regulated plant assuming particulate capture efficiency of $99.8 \%$; compliance FGD, although unspecified as to type; and operation at a $70 \%$ capacity factor.

d The coal is assumed to have a calorific value of $10,020 \mathrm{Btu} / \mathrm{lb}$ (typical).

e Swanson et al. (1976) provide coal trace element data. 
TABLE A.3.2 Calculated Annual Trace Element Emissions ${ }^{\text {a,b }}$ from a New, Mociern, 500-MWe Power Plant ${ }^{c}$ Firing U.S. Hanna, Wyoming, Bituminous Coal ${ }^{\text {d }}$

\begin{tabular}{|c|c|c|c|c|c|c|}
\hline Element & $\begin{array}{c}\text { Typical } \\
\text { Content } \\
(\mathrm{ppm})^{\mathrm{e}}\end{array}$ & $\begin{array}{c}\text { Calculated } \\
\text { Emissions } \\
\text { Based on } \\
\text { Typical } \\
\text { Content } \\
\text { (TPY) }\end{array}$ & $\begin{array}{c}\text { Typical } \\
\text { Content } \\
+2 \text { S.D. } \\
\text { (ppm) } \\
\end{array}$ & $\begin{array}{c}\text { Calculated } \\
\text { Emissions } \\
\text { Based on } \\
\text { Typical } \\
\text { Content } \\
+2 \text { S.D. } \\
\text { (TPY) } \\
\end{array}$ & $\begin{array}{c}\text { Maximum } \\
\text { Content } \\
(\mathrm{ppm})^{\mathrm{e}}\end{array}$ & $\begin{array}{c}\text { Calculated } \\
\text { Emissions } \\
\text { Based on } \\
\text { Maximum } \\
\text { Content } \\
\text { (TPY) } \\
\end{array}$ \\
\hline $\mathrm{Sb}$ & 0.4 & 0.01 & 0.8 & 0.03 & 0.9 & 0.03 \\
\hline As & 3 & 0.11 & 5 & 0.18 & 5 & 0.18 \\
\hline $\mathrm{Be}$ & 0.4 & 0.01 & 1.4 & 0.04 & 2.0 & 0.05 \\
\hline $\mathrm{Cd}$ & 0.2 & 0.007 & 0.4 & 0.01 & 0.5 & 0.02 \\
\hline $\mathrm{Cl}$ & 115 & 15.1 & 180 & 23.6 & 180 & 23.6 \\
\hline $\mathrm{Cr}$ & 5 & 0.07 & 9 & 0.12 & 10 & 0.13 \\
\hline Co & 1.6 & 0.02 & 4.6 & 0.07 & 7.0 & 0.11 \\
\hline F & 70 & 18.4 & 136 & 53.7 & 140 & 55.2 \\
\hline $\mathrm{Pb}$ & 4.2 & 0.10 & 9.0 & 0.21 & 9.3 & 0.22 \\
\hline $\mathrm{Mn}$ & 41 & 1.08 & 107 & 2.81 & 110 & 2.89 \\
\hline $\mathrm{Hg}$ & 0.05 & 0.06 & 0.10 & 0.12 & 0.10 & 0.12 \\
\hline $\mathrm{Ni}$ & 5 & 0.03 & 10 & 0.05 & 10 & 0.05 \\
\hline$P$ & 132 & 0.17 & 390 & 0.51 & 390 & 0.51 \\
\hline $\mathrm{Se}$ & 0.8 & 0.15 & 2.6 & 0.49 & 2.9 & 0.55 \\
\hline Th & 3.3 & 0.02 & 4.9 & 0.02 & 6.3 & 0.03 \\
\hline $\mathrm{U}$ & 1.5 & 0.02 & 2.2 & 0.03 & 2.2 & 0.03 \\
\hline Total & & 35.357 & & 81.99 & & 83.72 \\
\hline
\end{tabular}

a Bignoli (1989) provides several estimates of the quantity of elements expected to be mobilized in the EEC in the future from new PCF power plants.

b Szpunar, C.B., preliminary assessment results in progress, Argonne National Laboratory, Argonne, Illinois; these projections are based on current scientific thought about element partitioning during coal firing and additional unpublished estimates of the quantity of elements expected to be mobilized in the future from new PCF power plants.

c Hypothetical, new, modern, stringently regulated plant assuming particulate capture efficiency of $99.8 \%$; compliance FGD, although unspecified as to type; and operation at a $70 \%$ capacity factor.

$\mathrm{d}$ The coal is assumed to have a calorific value of $10,570 \mathrm{Btu} / \mathrm{lb}$ (typical).

e Swanson et al. (1976) provide coal trace element data. 
TABLE A.3.3 Calculated Annual Trace Element Emissions ${ }^{a, b}$ from a New, Modern, 500-MWe Power Plant ${ }^{c}$ Firing U.S. Black Mesa, Arizona, Bituminous Coal ${ }^{\mathrm{d}}$

\begin{tabular}{|c|c|c|c|c|c|c|}
\hline Element & $\begin{array}{c}\text { Typical } \\
\text { Content } \\
(\mathrm{ppm})^{\mathrm{e}}\end{array}$ & $\begin{array}{c}\text { Calculated } \\
\text { Emissions } \\
\text { Based on } \\
\text { Typical } \\
\text { Content } \\
\text { (TPY) } \\
\end{array}$ & $\begin{array}{c}\text { Typical } \\
\text { Content } \\
+2 \text { S.D. } \\
\text { (ppm) }\end{array}$ & $\begin{array}{c}\text { Calculated } \\
\text { Emissions } \\
\text { Based on } \\
\text { Typical } \\
\text { Content } \\
\text { + } 2 \text { S.D. } \\
\text { (TPY) } \\
\end{array}$ & $\begin{array}{c}\text { Maximum } \\
\text { Content } \\
(\mathrm{ppm})^{\mathbf{e}}\end{array}$ & $\begin{array}{c}\text { Calculated } \\
\text { Emissions } \\
\text { Based on } \\
\text { Maximum } \\
\text { Content } \\
\text { (TPY) } \\
\end{array}$ \\
\hline $\mathrm{Sb}$ & 0.3 & 0.009 & 0.5 & 0.02 & 0.6 & 0.02 \\
\hline As & 2 & 0.07 & 6 & 0.22 & 10 & 0.36 \\
\hline $\mathrm{Be}$ & 0.4 & 0.01 & 1.2 & 0.03 & 1.5 & 0.04 \\
\hline $\mathrm{Cd}$ & 0.09 & 0.003 & 0.17 & 0.006 & 0.2 & 0.007 \\
\hline $\mathrm{Cl}$ & 154 & 19.6 & 250 & 31.9 & 250 & 31.9 \\
\hline $\mathrm{Cr}$ & 3 & 0.04 & 7 & 0.09 & 10 & 0.13 \\
\hline Co & 1.2 & 0.02 & 2.6 & 0.03 & 3.0 & 0.04 \\
\hline $\mathbf{F}$ & 35 & 13.4 & 63 & 24.1 & 75 & 28.7 \\
\hline $\mathrm{Pb}$ & 2.4 & 0.05 & 4.6 & 0.11 & 5.6 & 0.13 \\
\hline $\mathbf{M n}$ & 10 & 0.25 & 17 & 0.43 & 17 & 0.43 \\
\hline $\mathrm{Hg}$ & 0.03 & 0.03 & 0.05 & 0.06 & 0.07 & 0.08 \\
\hline $\mathrm{Ni}$ & 2.8 & 0.01 & 6.0 & 0.03 & 7.0 & 0.04 \\
\hline $\mathrm{P}$ & 333 & 0.42 & 550 & 0.70 & 550 & 0.70 \\
\hline $\mathrm{Se}$ & 1.6 & 0.29 & 2.1 & 0.39 & 2.1 & 0.39 \\
\hline Th & 3.0 & 0.01 & 3.4 & 0.02 & 3.7 & 0.02 \\
\hline $\mathbf{U}$ & 0.5 & 0.008 & 1.1 & 0.02 & 1.1 & 0.02 \\
\hline Total & & 34.22 & & 58.156 & & 63.007 \\
\hline
\end{tabular}

a Bignoli (1989) provides several estimates of the quantity of elements expected to be mobilized in the EEC in the future from new PCF power plants.

b Szpunar, C.B., preliminary assessment results in progress, Argonne National Laboratory, Argonne, Illinois; these projections are based on current scientific thought about element partitioning during coal firing and additional unpublished estimates of the quantity of elements expected to be mobilized in the future from new PCF power plants.

c Hypothetical, new, modern, stringently regulated plant assuming particulate capture efficiency of $99.8 \%$; compliance FGD, although unspecified as to type; and operation at a $70 \%$ capacity factor.

$\mathrm{d}$ The coal is assumed to have a calorific value of $10,890 \mathrm{Btu} / \mathrm{lb}$ (typical).

e Swanson et al. (1976) provide coal trace element data. 
TABLE A.3.4 Calculated Annual Trace Element Emissions ${ }^{a, b}$ from a New, Modern, 500-MWe Power Plant ${ }^{c}$ Firing U.S. Uinta, Utah, Bituminous Coal ${ }^{d}$

\begin{tabular}{|c|c|c|c|c|c|c|}
\hline Element & $\begin{array}{l}\text { Typical } \\
\text { Content } \\
\text { (ppm) }^{\mathrm{e}}\end{array}$ & $\begin{array}{c}\text { Calculated } \\
\text { Emissions } \\
\text { Based on } \\
\text { Typical } \\
\text { Content } \\
\text { (TPY) }\end{array}$ & $\begin{array}{c}\text { Typical } \\
\text { Content } \\
+2 \text { S.D. } \\
\text { (ppm) }\end{array}$ & $\begin{array}{c}\text { Calculated } \\
\text { Emissions } \\
\text { Based on } \\
\text { Typical } \\
\text { Content } \\
\text { + } 2 \text { S.D. } \\
\text { (TPY) }\end{array}$ & $\begin{array}{c}\text { Maximum } \\
\text { Content } \\
\text { (ppm) }^{\mathrm{e}}\end{array}$ & $\begin{array}{c}\text { Calculated } \\
\text { Emissions } \\
\text { Based on } \\
\text { Maximum } \\
\text { Content } \\
\text { (TPY) }\end{array}$ \\
\hline $\mathrm{Sb}$ & 0.2 & 0.005 & 0.6 & 0.02 & 0.9 & 0.02 \\
\hline As & 1 & 0.03 & 3 & 0.09 & 8 & 0.25 \\
\hline $\mathrm{Be}$ & 0.4 & 0.009 & 1.0 & 0.02 & 1.0 & 0.02 \\
\hline Cd & 0.1 & 0.003 & 0.16 & 0.005 & 0.2 & 0.006 \\
\hline $\mathrm{Cl}$ & 96 & 10.6 & 184 & 20.4 & 240 & 26.6 \\
\hline $\mathrm{Cr}$ & 7 & 0.08 & 20 & 0.22 & 30 & 0.33 \\
\hline Co & 1.2 & 0.02 & 2.4 & 0.03 & 3.0 & 0.04 \\
\hline $\mathbf{F}$ & 61 & 20.3 & 169 & 56.1 & 240 & 79.8 \\
\hline $\mathrm{Pb}$ & 3.6 & 0.07 & 6.8 & 0.13 & 7.7 & 0.15 \\
\hline $\mathrm{Mn}$ & 18 & 0.40 & 84 & 1.87 & 180 & 3.99 \\
\hline $\mathrm{Hg}$ & 0.05 & 0.05 & 0.21 & 0.20 & 0.38 & 0.37 \\
\hline $\mathrm{Ni}$ & 2.8 & 0.01 & 6.8 & 0.03 & 10 & 0.04 \\
\hline $\mathbf{P}$ & 137 & 0.15 & 267 & 0.30 & 280 & 0.31 \\
\hline $\mathrm{Se}$ & 1.8 & 0.29 & 3.0 & 0.48 & 3.4 & 0.54 \\
\hline Th & 3.4 & 0.01 & 5.6 & 0.02 & 7.9 & 0.03 \\
\hline $\mathbf{U}$ & 0.9 & 0.01 & 2.3 & 0.03 & 3.1 & 0.04 \\
\hline Total & & 32.037 & & 79.945 & & 112.536 \\
\hline
\end{tabular}

a Bignoli (1989) provides several estimates of the quantity of elements expected to be mobilized in the EEC in the future from new PCF power plants.

b Szpunar, C.B., preliminary assessment results in progress, Argonne National Laboratory, Argonne, Illinois; these projections are based on current scientific thought about element partitioning during coal firing and additional unpublished estimates of the quantity of elements expected to be mobilized in the future from new PCF power plants.

c Hypothetical, new, modern, stringently regulated plant assuming particulate capture efficiency of $99.8 \%$; compliance FGD, although unspecified as to type; and operation at a $70 \%$ capacity factor.

d The coal is assumed to have a calorific value of $12,530 \mathrm{Btu} / \mathrm{lb}$ (typical).

e Swanson et al. (1976) provide coal trace element data. 
TABLE A.4 Calculated Annual Trace Element Emissions ${ }^{a, b}$ from a New, Modern, 500-MWe Power Plant ${ }^{c}$ Firing U.S. Northern Plains Lignite/ Subbituminous Coal ${ }^{\mathrm{d}}$

\begin{tabular}{|c|c|c|c|c|}
\hline Element & $\begin{array}{l}\text { Typical } \\
\text { Content } \\
(\mathrm{ppm})^{\mathrm{e}}\end{array}$ & $\begin{array}{c}\text { Calculated } \\
\text { Emissions } \\
\text { Based on } \\
\text { Typical } \\
\text { Content } \\
\text { (TPY) }\end{array}$ & $\begin{array}{c}\text { Maximum } \\
\text { Content } \\
(\mathrm{ppm})^{\mathrm{f}}\end{array}$ & $\begin{array}{c}\text { Calculated } \\
\text { Emissions } \\
\text { Based on } \\
\text { Maximum } \\
\text { Content } \\
\text { (TPY) }\end{array}$ \\
\hline $\mathrm{Sb}$ & 0.6 & 0.02 & 9.1 & 0.36 \\
\hline As & 3 & 0.14 & 420 & 19.3 \\
\hline $\mathrm{Be}$ & 0.5 & 0.02 & 14 & 0.46 \\
\hline $\mathrm{Cd}$ & 0.2 & 0.009 & 2.7 & 0.12 \\
\hline $\mathrm{Cl}$ & 131 & 21.5 & $290^{g}$ & 47.5 \\
\hline $\mathrm{Cr}$ & 5 & 0.08 & 66 & 1.08 \\
\hline Co & 2 & 0.04 & 43 & 0.84 \\
\hline $\mathbf{F}$ & 45 & 22.1 & 1,400 & 687 \\
\hline $\mathrm{Pb}$ & 5.3 & 0.16 & 58 & 1.70 \\
\hline Mn & 51 & 1.67 & 660 & 21.6 \\
\hline $\mathrm{Hg}$ & 0.09 & 0.13 & 12 & 17.5 \\
\hline $\mathrm{Ni}$ & 3 & 0.02 & 84 & 0.55 \\
\hline $\mathbf{P}$ & 208 & 0.34 & $640^{g}$ & 1.05 \\
\hline $\mathrm{Se}$ & 1.0 & 0.23 & 16 & 3.77 \\
\hline Th & 2.7 & 0.02 & 42 & 0.27 \\
\hline $\mathbf{U}$ & 0.9 & 0.02 & 16 & 0.31 \\
\hline Total & & 46.499 & & 803.41 \\
\hline
\end{tabular}

a Bignoli (1989) provides several estimates of the quantity of elements expected to be mobilized in the EEC in the future from new PCF power plants.

b Szpunar, C.B., preliminary assessment results in progress, Argonne National Laboratory, Argonne, Illinois; these projections are based on current scientific thought about element partitioning during coal firing and additional unpublished estimates of the quantity of elements expected to be mobilized in the future from new PCF power plants.

c Hypothetical, new, modern, stringently regulated plant assuming particulate capture efficiency of $99.8 \%$; compliance FGD, although unspecified as to type; and operation at a $70 \%$ capacity factor.

$\mathrm{d}$ The coal is assumed to have a calorific value of $8,480 \mathrm{Btu} / \mathrm{lb}$ (typical).

e Swanson et al. (1976) provide coal trace element data.

f Zubovic et al. (1979).

g Montana and Wyoming subbituminous coals only. 
TABLE A.4.1 Calculated Annual Trace Element Emissions ${ }^{\mathrm{a}, \mathrm{b}}$ from a New, Modern, 500-MWe Power Plant ${ }^{c}$ Firing U.S. North Dakota Lignite ${ }^{d}$

\begin{tabular}{|c|c|c|c|c|c|c|}
\hline Element & $\begin{array}{c}\text { Typical } \\
\text { Content } \\
(\mathrm{ppm})^{\mathrm{e}}\end{array}$ & $\begin{array}{c}\text { Calculated } \\
\text { Emissions } \\
\text { Based on } \\
\text { Typical } \\
\text { Content } \\
\text { (TPY) }\end{array}$ & $\begin{array}{c}\text { Typical } \\
\text { Content } \\
+2 \text { S.D. } \\
\text { (ppm) }\end{array}$ & $\begin{array}{c}\text { Calculated } \\
\text { Emissions } \\
\text { Based on } \\
\text { Typical } \\
\text { Content } \\
\text { + } 2 \text { S.D. } \\
\text { (TPY) }\end{array}$ & $\begin{array}{c}\text { Maximum } \\
\text { Content } \\
(\mathrm{ppm})^{\mathrm{e}}\end{array}$ & $\begin{array}{c}\text { Calculated } \\
\text { Emissions } \\
\text { Based on } \\
\text { Maximum } \\
\text { Content } \\
\text { (TPY) }\end{array}$ \\
\hline $\mathrm{Sb}$ & 0.3 & 0.01 & 1.1 & 0.05 & 1.8 & 0.08 \\
\hline As & 7 & 0.38 & 21 & 1.14 & 30 & 1.63 \\
\hline $\mathrm{Be}$ & 0.5 & 0.02 & 3.7 & 0.14 & 7.0 & 0.27 \\
\hline Cd & 0.12 & 0.006 & 0.22 & 0.01 & 0.30 & 0.02 \\
\hline $\mathrm{Cl}$ & 173 & 33.5 & 260 & 50.4 & 260 & 50.4 \\
\hline $\mathrm{Cr}$ & 2.1 & 0.04 & 4.9 & 0.10 & 7.0 & 0.14 \\
\hline Co & 1.1 & 0.02 & 2.5 & 0.06 & 3.0 & 0.07 \\
\hline$F$ & 26 & 15.1 & 40 & 23.2 & 40 & 23.2 \\
\hline $\mathrm{Pb}$ & 3.4 & 0.12 & 7.2 & 0.25 & 8.3 & 0.29 \\
\hline $\mathrm{Mn}$ & 48 & 1.86 & 98 & 3.80 & 120 & 4.65 \\
\hline $\mathrm{Hg}$ & 0.12 & 0.21 & 0.40 & 0.68 & 0.49 & 0.84 \\
\hline $\mathrm{Ni}$ & 2 & 0.01 & 4 & 0.03 & 5.0 & 0.04 \\
\hline $\mathbf{P}$ & 318 & 0.62 & 530 & 1.03 & 530 & 1.03 \\
\hline $\mathrm{Se}$ & 0.8 & 0.22 & 1.8 & 0.50 & 2.0 & 0.56 \\
\hline $\mathrm{Th}$ & 3.5 & 0.03 & 5.9 & 0.04 & 8.0 & 0.06 \\
\hline $\mathrm{U}$ & 0.7 & 0.02 & 1.7 & 0.04 & 2.6 & 0.06 \\
\hline Total & & 52.166 & & 81.47 & & 83.34 \\
\hline
\end{tabular}

a Bignoli (1989) provides several estimates of the quantity of elements expected to be mobilized in the EEC in the future from new PCF power plants.

b Szpunar, C.B., preliminary assessment results in progress, Argonne National

Laboratory, Argonne, Illinois; these projections are based on current scientific thought about element partitioning during coal firing and additional unpublished estimates of the quantity of elements expected to be mobilized in the future from new PCF power plants.

c Hypothetical, new, modern, stringently regulated plant assuming particulate capture efficiency of $99.8 \%$; compliance FGD, although unspecified as to type; and operation at a $70 \%$ capacity factor.

d The coal is assumed to have a calorific value of 7,170 Btu/lb (typical).

e Swanson et al. (1976) provide coal trace element data. 
TABLE A.4.2 Projected Quantity ${ }^{\mathrm{a}, \mathrm{b}}$ of Trace Elements Likely to Be Emitted Annually from a New, Modern, 500-MWe Power Plant ${ }^{\mathrm{c}}$ Firing U.S. Wyeming Subbituminous Coal ${ }^{d}$

\begin{tabular}{lcccccc}
\hline & Calculated & & $\begin{array}{c}\text { Calculated } \\
\text { Emissions } \\
\text { Based on } \\
\text { Typical }\end{array}$ & & $\begin{array}{c}\text { Calculated } \\
\text { Emissions } \\
\text { Based on }\end{array}$ & $\begin{array}{c}\text { Typical } \\
\text { Based on }\end{array}$ \\
Element & $\begin{array}{c}\text { Typical } \\
\text { Content } \\
\text { (ppm) }\end{array}$ & $\begin{array}{c}\text { Typical } \\
\text { Content } \\
\text { (TPY) }\end{array}$ & $\begin{array}{c}\text { Content } \\
+2 \text { S.D. } \\
\text { (ppm) }\end{array}$ & $\begin{array}{c}\text { Content } \\
+2 \text { S.D. } \\
\text { (TPY) }\end{array}$ & $\begin{array}{c}\text { Maximum } \\
\text { Content } \\
\text { (ppm) }\end{array}$ & $\begin{array}{c}\text { Maximum } \\
\text { Content } \\
\text { (TPY) }\end{array}$ \\
\hline Sb & 0.5 & 0.02 & 1.3 & 0.05 & 2.1 & 0.08 \\
As & 3 & 0.13 & 7 & 0.30 & 12 & 0.52 \\
Be & 0.4 & 0.01 & 1.2 & 0.04 & 1.5 & 0.05 \\
Cd & 0.18 & 0.007 & 0.40 & 0.02 & 0.40 & 0.02 \\
Cl & 144 & 22.2 & 272 & 41.9 & 290 & 44.7 \\
Cr & 7.7 & 0.12 & 18.9 & 0.29 & 30.0 & 0.46 \\
Co & 2.4 & 0.04 & 5.8 & 0.11 & 7.0 & 0.13 \\
F & 68 & 31.5 & 160 & 73.8 & 255 & 117.9 \\
Pb & 7.2 & 0.20 & 25.0 & 0.69 & 42.1 & 1.17 \\
Mn & 75 & 2.31 & 251 & 7.73 & 370 & 11.4 \\
Hg & 0.11 & 0.15 & 0.25 & 0.34 & 0.29 & 0.40 \\
Ni & 6.0 & 0.04 & 14.8 & 0.09 & 20.0 & 0.12 \\
P & 276 & 0.42 & 570 & 0.88 & 640 & 0.99 \\
Se & 1.1 & 0.24 & 3.1 & 0.69 & 6.7 & 1.49 \\
Th & 3.6 & 0.02 & 5.8 & 0.03 & 7.2 & 0.04 \\
U & 1.0 & 0.02 & 2.4 & 0.04 & 2.9 & 0.05 \\
Total & & 57.427 & & 127.00 & & 179.52 \\
\hline
\end{tabular}

a Bignoli (1989) provides several estimates of the quantity of elements expected to be mobilized in the EEC in the future from new PCF power plants.

b Szpunar, C.B., preliminary assessment results in progress, Argonne National Laboratory, Argonne, Illinois; these projections are based on current scientific thought about element partitioning during coal firing and additional unpublished estimates of the quantity of elements expected to be mobilized in the future from new PCF power plants.

c Hypothetical, new, modern, stringently regulated plant assuming particulate capture efficiency of $99.8 \%$; compliance FGD, although unspecified as to type; and operation at a $70 \%$ capacity factor.

d The coal is assumed to have a calorific value of $9,010 \mathrm{Btu} / \mathrm{lb}$ (typical).

e Swanson et al. (1976) provide coal trace element data. 
TABLE A.4.3 Calculated Annual Trace Element Emissions ${ }^{\mathrm{a}, \mathrm{b}}$ from a New, Modern, 500-MWe Power Plant ${ }^{\mathrm{c}}$ Firing U.S. Montana Subbituminous Coal ${ }^{\mathrm{d}}$

\begin{tabular}{|c|c|c|c|c|c|c|}
\hline Element & $\begin{array}{l}\text { Typical } \\
\text { Content } \\
(p p m)^{\mathrm{e}}\end{array}$ & $\begin{array}{c}\text { Calculated } \\
\text { Emissions } \\
\text { Based on } \\
\text { Typical } \\
\text { Content } \\
\text { (TPY) }\end{array}$ & $\begin{array}{c}\text { Typical } \\
\text { Content } \\
+2 \text { S.D. } \\
\text { (ppm) }\end{array}$ & $\begin{array}{c}\text { Calculated } \\
\text { Emissions } \\
\text { Based on } \\
\text { Typical } \\
\text { Content } \\
\text { + } 2 \text { S.D. } \\
\text { (TPY) }\end{array}$ & $\begin{array}{c}\text { Maximum } \\
\text { Content } \\
(\mathrm{ppm})^{\mathbf{e}}\end{array}$ & $\begin{array}{c}\text { Calculated } \\
\text { Emissions } \\
\text { Based on } \\
\text { Maximum } \\
\text { Content } \\
\text { (TPY) }\end{array}$ \\
\hline $\mathrm{Sb}$ & 0.8 & 0.03 & 1.8 & 0.07 & 2.5 & 0.10 \\
\hline As & 2 & 0.09 & 8 & 0.37 & 15 & 0.70 \\
\hline $\mathrm{Be}$ & 0.5 & 0.02 & 1.3 & 0.04 & 1.5 & 0.05 \\
\hline $\mathrm{Cd}$ & 0.11 & 0.005 & 0.17 & 0.008 & 0.2 & 0.009 \\
\hline $\mathrm{Cl}$ & 100 & 16.6 & 168 & 27.9 & 170 & 28.2 \\
\hline $\mathrm{Cr}$ & 3.2 & 0.05 & 8.4 & 0.14 & 15.0 & 0.25 \\
\hline Co & 1.2 & 0.02 & 2.0 & 0.04 & 2.0 & 0.04 \\
\hline $\mathbf{F}$ & 36 & 17.91 & 70 & 34.8 & 80 & 39.9 \\
\hline $\mathrm{Pb}$ & 3.5 & 0.10 & 5.9 & 0.17 & 6.2 & 0.18 \\
\hline Mn & 37 & 1.23 & 97 & 3.21 & 140 & 4.64 \\
\hline $\mathrm{Hg}$ & 0.07 & 0.10 & 0.19 & 0.28 & 0.31 & 0.46 \\
\hline $\mathrm{Ni}$ & 1.8 & 0.01 & 3.6 & 0.02 & 5.0 & 0.03 \\
\hline $\mathbf{P}$ & 99 & 0.16 & 189 & 0.31 & 260 & 0.43 \\
\hline $\mathrm{Se}$ & 0.7 & 0.17 & 2.3 & 0.55 & 3.4 & 0.81 \\
\hline Th & 2.7 & 0.02 & 4.5 & 0.03 & 5.0 & 0.03 \\
\hline $\mathbf{U}$ & 0.8 & 0.02 & 1.6 & 0.03 & 1.7 & 0.03 \\
\hline Total & & 36.535 & & 67.968 & & 75.859 \\
\hline
\end{tabular}

a Bignoli (1989) provides several estimates of the quantity of elements expected to be mobilized in the EEC in the future from new PCF power plants.

b Szpunar, C.B., preliminary assessment results in progress, Argonne National Laboratory, Argonne, Illinois; these projections are based on current scientific thought about element partitioning during coal firing and additional unpublished estimates of the quantity of elements expected to be mobilized in the future from new PCF power plants.

c Hypothetical, new, modern, stringently regulated plant assuming particulate capture efficiency of $99.8 \%$; compliance FGD, although unspecified as to type; and operation at a $70 \%$ capacity factor.

d The coal is assumed to have a calorific value of $8,380 \mathrm{Btu} / \mathrm{lb}$ (typical).

e Swanson et al. (1976) provide coal trace element data. 
TABLE A.5 Calculated Annual Trace Element Emissions ${ }^{a, b}$ from a New, Modern, 500-MWe Power Plant ${ }^{c}$ Firing U.S. Gulf Lignite ${ }^{d}$

\begin{tabular}{|c|c|c|c|c|}
\hline Element & $\begin{array}{l}\text { Typical } \\
\text { Content } \\
(\text { ppm) }\end{array}$ & $\begin{array}{c}\text { Calculated } \\
\text { Emissions } \\
\text { Based on } \\
\text { Typical } \\
\text { Content } \\
\text { (TPY) }\end{array}$ & $\begin{array}{c}\text { Maximum } \\
\text { Content } \\
(\mathrm{ppm})^{\mathrm{e}, \mathrm{f}}\end{array}$ & $\begin{array}{c}\text { Calculated } \\
\text { Emissions } \\
\text { Based on } \\
\text { Maximum } \\
\text { Content } \\
\text { (TPY) }\end{array}$ \\
\hline $\mathrm{Sb}$ & 0.9 & 0.07 & 5.2 & 0.42 \\
\hline As & 6 & 0.56 & 31 & 2.89 \\
\hline $\mathrm{Be}$ & 2 & 0.13 & 15 & 1.00 \\
\hline $\mathrm{Cd}$ & 1.3 & 0.12 & 5.5 & 0.49 \\
\hline $\mathrm{Cl}$ & 646 & 215 & $1,400^{e, g}$ & 466 \\
\hline $\mathrm{Cr}$ & 20 & 0.67 & 87 & 2.90 \\
\hline Co & 7 & 0.28 & 30 & 1.20 \\
\hline $\mathbf{F}$ & 124 & 124 & $350^{\mathrm{e}}$ & 348 \\
\hline $\mathrm{Pb}$ & 20 & 1.20 & 129 & 7.73 \\
\hline Mn & 240 & 16.0 & 1,075 & 71.6 \\
\hline $\mathrm{Hg}$ & 0.18 & 0.53 & 1.5 & 4.45 \\
\hline $\mathrm{Ni}$ & 20 & 0.27 & 79 & 1.05 \\
\hline $\mathbf{P}$ & 1,255 & 4.18 & $2,600^{e, g}$ & 8.66 \\
\hline $\mathrm{Se}$ & 7.0 & 3.36 & 18 & 8.63 \\
\hline Th & 8.3 & 0.11 & 28 & 0.37 \\
\hline $\mathrm{U}$ & 3.2 & 0.13 & 17 & 0.68 \\
\hline Total & & 366.61 & & 926.07 \\
\hline
\end{tabular}

a Bignoli (1989) provides several estimates of the quantity of elements expected to be mobilized in the EEC in the future from new PCF power plants.

b Szpunar, C.B., preliminary assessment results in progress, Argonne National Laboratory, Argonne, Illinois; these projections are based on current scientific thought about element partitioning during coal firing and additional unpublished estimates of the quantity of elements expected to be mobilized in the future from new PCF power plants.

c Hypothetical, new, modern, stringently regulated plant assuming particulate capture efficiency of $99.8 \%$; compliance FGD, although unspecified as to type; and operation at a $70 \%$ capacity factor.

$\mathrm{d}$ The coal is assumed to have a calorific value of $4,170 \mathrm{Btu} / \mathrm{lb}$ (typical).

e Swanson et al. (1976) provide coal trace element data.

f White et al. (1983).

g Alabama lignite only. 
TABLE A.5.1 Calculated Annual Trace Element Emissions ${ }^{a, b}$ from a New, Modern, 500-MWe Power Plant ${ }^{c}$ Firing U.S. Alabama Lignite ${ }^{d}$

\begin{tabular}{|c|c|c|c|c|c|c|}
\hline Element & $\begin{array}{l}\text { Typical } \\
\text { Content } \\
(p p m)^{e}\end{array}$ & $\begin{array}{c}\text { Calculated } \\
\text { Emissions } \\
\text { Based on } \\
\text { Typical } \\
\text { Content } \\
\text { (TPY) }\end{array}$ & $\begin{array}{c}\text { Typical } \\
\text { Content } \\
+2 \text { S.D. } \\
\text { (ppm) }\end{array}$ & $\begin{array}{c}\text { Calculated } \\
\text { Emissions } \\
\text { Based on } \\
\text { Typical } \\
\text { Content } \\
+2 \text { S.D. } \\
\text { (TPY) }\end{array}$ & $\begin{array}{c}\text { Maximum } \\
\text { Content } \\
(\mathrm{ppm})^{\mathbf{e}}\end{array}$ & $\begin{array}{c}\text { Calculated } \\
\text { Emissions } \\
\text { Based on } \\
\text { Maximum } \\
\text { Content } \\
\text { (TPY) }\end{array}$ \\
\hline $\mathrm{Sb}$ & 0.6 & 0.05 & 1.4 & 0.12 & 1.6 & 0.14 \\
\hline As & 5 & 0.50 & 13 & 1.29 & 16 & 1.59 \\
\hline $\mathrm{Be}$ & 2.0 & 0.14 & 4.2 & 0.29 & 5.0 & 0.35 \\
\hline $\mathrm{Cd}$ & 1.69 & 0.16 & 4.51 & 0.43 & 5.55 & 0.53 \\
\hline $\mathrm{Cl}$ & 646 & 229 & 1,314 & 466 & 1,400 & 497 \\
\hline $\mathrm{Cr}$ & 24 & 0.85 & 66 & 2.35 & 70 & 2.49 \\
\hline Co & 5 & 0.21 & 11 & 0.47 & 15 & 0.64 \\
\hline $\mathbf{F}$ & 127 & 135 & 303 & 324 & 340 & 363 \\
\hline $\mathrm{Pb}$ & 27.2 & 1.74 & 78.8 & 5.04 & 130 & 8.31 \\
\hline Mn & 297 & 21.1 & 619 & 44.0 & 690 & 49.0 \\
\hline $\mathrm{Hg}$ & 0.13 & 0.41 & 0.33 & 1.05 & 0.41 & 1.30 \\
\hline $\mathrm{Ni}$ & 17 & 0.24 & 39 & 0.55 & 50 & 0.71 \\
\hline $\mathbf{P}$ & 1,255 & 4.46 & 2,463 & 8.75 & 2,600 & 9.24 \\
\hline Se & 6.8 & 3.48 & 15.2 & 7.78 & 17.0 & 8.70 \\
\hline $\mathrm{Th}$ & 5.1 & 0.07 & 11.1 & 0.16 & 14.5 & 0.21 \\
\hline $\mathrm{U}$ & 2.5 & 0.11 & 5.3 & 0.22 & 5.7 & 0.24 \\
\hline Total & & 397.52 & & 862.50 & & 943.45 \\
\hline
\end{tabular}

a Bignoli (1989) provides several estimates of the quantity of elements expected to be mobilized in the EEC in the future from new PCF power plants.

b Szpunar, C.B., preliminary assessment results in progress, Argonne National Laboratory, Argonne, Illinois; these projections are based on current scientific thought about element partitioning during coal firing and additional unpublished estimates of the quantity of elements expected to be mobilized in the future from new PCF power plants.

c Hypothetical, new, modern, stringently regulated plant assuming particulate capture efficiency of $99.8 \%$; compliance FGD, although unspecified as to type; and operation at a $70 \%$ capacity factor.

d The coal is assumed to have a calorific value of $3,910 \mathrm{Btu} / \mathrm{lb}$ (typical).

e Swanson et al. (1976) provide coal trace element data. 
TABLE A.6 Calculated Annual Trace Element Emissions ${ }^{\mathrm{a}, \mathrm{b}}$ from a New, Modern, 500-MWe Power Plant ${ }^{c}$ Firing U.S. Alaska Subbituminous Coal ${ }^{d}$

\begin{tabular}{|c|c|c|c|c|c|c|}
\hline Element & $\begin{array}{l}\text { Typical } \\
\text { Content } \\
(\text { ppm) }\end{array}$ & $\begin{array}{c}\text { Calculated } \\
\text { Emissions } \\
\text { Based on } \\
\text { Typical } \\
\text { Content } \\
\text { (TPY) } \\
\end{array}$ & $\begin{array}{c}\text { Typical } \\
\text { Content } \\
+2 \text { S.D. } \\
\text { (ppm) }\end{array}$ & $\begin{array}{c}\text { Calculated } \\
\text { Emissions } \\
\text { Based on } \\
\text { Typical } \\
\text { Content } \\
\text { + } 2 \text { S.D. } \\
\text { (TPY) } \\
\end{array}$ & $\begin{array}{c}\text { Maximum } \\
\text { Content } \\
\text { (ppm) }^{\mathbf{e}}\end{array}$ & $\begin{array}{c}\text { Calculated } \\
\text { Emissions } \\
\text { Based on } \\
\text { Maximum } \\
\text { Content } \\
\text { (TPY) } \\
\end{array}$ \\
\hline Sb & 2.1 & 0.09 & 5.9 & 0.24 & 8.1 & 0.33 \\
\hline As & 2 & 0.10 & 4 & 0.19 & 5 & 0.24 \\
\hline $\mathrm{Be}$ & 0.5 & 0.02 & 2.1 & 0.07 & 3.0 & 0.10 \\
\hline $\mathrm{Cd}$ & 0.2 & 0.009 & 0.49 & 0.02 & 0.6 & 0.03 \\
\hline $\mathrm{Cl}$ & 138 & 23.7 & 302 & 51.9 & 380 & 65.3 \\
\hline $\mathrm{Cr}$ & 19 & 0.33 & 51 & 0.87 & 70 & 1.20 \\
\hline Co & 4.5 & 0.09 & 10 & 0.21 & 10 & 0.21 \\
\hline $\mathbf{F}$ & 110 & 56.7 & 258 & 133 & 335 & 173 \\
\hline $\mathrm{Pb}$ & 5.6 & 0.17 & 12.0 & 0.37 & 15.0 & 1.46 \\
\hline $\mathbf{M n}$ & 60 & 2.06 & 130 & 4.47 & 130 & 4.47 \\
\hline $\mathrm{Hg}$ & 0.06 & 0.09 & 0.20 & $0 . \$ 1$ & 0.30 & 0.46 \\
\hline $\mathrm{Ni}$ & 12 & 0.08 & 24 & 0.17 & 30 & 0.21 \\
\hline $\mathbf{P}$ & 157 & 0.27 & 403 & 0.69 & 450 & 0.77 \\
\hline $\mathrm{Se}$ & 2.1 & 0.52 & 7.9 & 1.95 & 11.0 & 2.72 \\
\hline Th & 5.6 & 0.04 & 13.4 & 0.09 & 17.5 & 0.12 \\
\hline $\mathbf{U}$ & 1.5 & 0.03 & 3.9 & $0 . \AA \Omega$ & $\tilde{3} .2$ & 0.11 \\
\hline Total & & 84.299 & & i94.63 & & 248.03 \\
\hline
\end{tabular}

a Bignoli (1989) provides several estimates of the quantity of elements expecter to be mobilized in the EEC in the future from nev PCF power plants.

b Szpunar, C.B., preliminary assessment results in progress, Argonne National Laboratory, Argonne, Illinois; these projections are based on current scientific thought about element partitioning during coal firing and additional unpublished estimates of the quantity of elements expected to be mobilized in the future from new PCF power plants.

c Hypothetical, new, modern, stringently regulated plant assuming particulate capture efficiency of $99.8 \%$; compliance FGD, although unspecified as to type; and operation at a $70 \%$ capacity factor.

d The coal is assumed to have a calorific value of $8,080 \mathrm{Btu} / \mathrm{lb}$ (typical).

e Swanson et al. (1976) provide coal trace element data. 
TABLE A.7 Calculated Annual Trace Element Emissions ${ }^{\text {a,b }}$ from a New, Modern, 500-MWe Power Plant ${ }^{c}$ Firing U.S. Pennsylvania Anthracite ${ }^{d}$

\begin{tabular}{|c|c|c|c|c|c|c|}
\hline Element & $\begin{array}{l}\text { Typical } \\
\text { Content } \\
(p p m)^{e}\end{array}$ & $\begin{array}{c}\text { Calculated } \\
\text { Emissions } \\
\text { Based on } \\
\text { Typical } \\
\text { Content } \\
\text { (TPY) }\end{array}$ & $\begin{array}{c}\text { Typical } \\
\text { Content } \\
+2 \text { S.D. } \\
\text { (ppm) }\end{array}$ & $\begin{array}{c}\text { Calculated } \\
\text { Emissions } \\
\text { Based on } \\
\text { Typical } \\
\text { Content } \\
+2 \text { S.D. } \\
\text { (TPY) }\end{array}$ & $\begin{array}{c}\text { Maximum } \\
\text { Content } \\
(\mathrm{ppm})^{\mathrm{e}}\end{array}$ & $\begin{array}{c}\text { Calculated } \\
\text { Emissions } \\
\text { Based on } \\
\text { Maximum } \\
\text { Content } \\
\text { (TPY) }\end{array}$ \\
\hline $\mathrm{Sb}$ & 1.1 & 0.03 & 5.1 & 0.13 & 12.5 & 0.33 \\
\hline As & 7 & 0.21 & 45 & 1.37 & 140 & 4.26 \\
\hline $\mathrm{Be}$ & 1.4 & 0.03 & 3.2 & 0.07 & 5.0 & 0.11 \\
\hline $\mathrm{Cd}$ & 0.23 & 0.007 & 1.09 & 0.03 & $\mathbf{3 . 0 0}$ & 0.09 \\
\hline $\mathrm{Cl}$ & 142 & 15.4 & 446 & 48.6 & 1,100 & 120 \\
\hline $\mathrm{Cr}$ & 22 & 0.24 & 48 & 0.52 & 70 & 0.76 \\
\hline Co & 8 & 0.10 & 25 & 0.32 & 50 & 0.65 \\
\hline$F$ & 64 & 20.9 & 178 & 57.9 & 290 & 94.5 \\
\hline $\mathrm{Pb}$ & 9.3 & 0.18 & 20.7 & 0.40 & 24.2 & 0.47 \\
\hline Mn & 31 & 0.67 & 101 & 2.19 & 210 & 4.56 \\
\hline $\mathrm{Hg}$ & 0.16 & 0.15 & 0.56 & 0.54 & 1.25 & 1.21 \\
\hline $\mathrm{Ni}$ & 19 & 0.08 & 45 & 0.19 & 70 & 0.30 \\
\hline $\mathrm{P}$ & 178 & 0.19 & 564 & 0.61 & 950 & 1.03 \\
\hline $\mathrm{Se}$ & 3.5 & 0.55 & 8.7 & 1.36 & 13.0 & 2.03 \\
\hline $\mathrm{Th}$ & 5.6 & 0.02 & 11.4 & 0.05 & 14.4 & 0.06 \\
\hline $\mathrm{U}$ & 1.8 & 0.02 & 8.4 & 0.11 & 25.2 & 0.33 \\
\hline Total & & 38.777 & & 114.39 & & 230.69 \\
\hline
\end{tabular}

a Bignoli (1989) krovides several estimates of the quantity of elements expected to be mobilized in the EEC in the future from new PCF power plants.

b Szpunar, C.B., preliminary assessment results in progress, Argonne National Laboratory, Argonne, Illinois; these projections are based on current scientific thought about element partitioning during cnal firing and additional unpublished estimates of the quantity of elements expected to be mobilized in the future from new PCF power plants.

c Hypothetical, new, modern, stringently regulated plant assuming particulate capture efficiency of $99.8 \%$; compliance FGD, although unspecified as to type; and operation at a $70 \%$ capacity factor.

d The coal is assumed to have a calorific value of $12,780 \mathrm{Btu} / \mathrm{b}$ (typical).

e Swanson et al. (1976) provide coal trace element data. 


\section{REFERENCES}

Abbott, D.T., et al., 1984, Radionuclides in Western Coal, abstract, Chemical Abstracts, 100:141871 (1984).

Abermethy, R.F., and F.H. Gibson, 1963, Rare Elements in Coal, information circular 8163, U.S. Department of the Interior, Bureau of Mines, Washington, D.C.

Abernethy, R.F., et al., 1969, Major Ash Constituents in U.S. Coals, report of investigations 7240, U.S. Department of the Interior, Bureau of Mines, Washington, D.C.

Affolter, R.H., and G.D. Stricker, 1987, "Geochemistry of Coal from the Cretaceous Corwin and Chandler Formations, National Petroleum Reserve in Alaska," in Alaskan North Slope Geology, 1. Tailleur and P. Wellmer (editors), Society of Economic Paleontologists, Calif., Vol. 1, pp. 217-224.

Airey, D., 1982, The Contributions from Coal and Industrial Materials to Mercury in Air, Rainwater, and Snow, The Science of the Total Environment, 25:19-40.

Akers, D.J., et al., 1989, Trace Elements in Coal and Coal Wastes, report EPRI GS-6575, prepared by Kaiser Engineers, Inc., Homer City, Penn., for Electric Power Research Institute, Palo Alto, Calif., Dec.

Andren, A.W., et al., 1975, "Selenium in Coal-Fired Steam Plant Emissions," Environmental Science and Technology, 9:856-858.

Austin, L.S., and G.E. Millward, 1988, "Simulated Effects of Tropospheric Emissions on the Global Antimony Cycle," Atmospheric Environment, 22:1395-1403.

Bennett, B.G., 1982, "Exposure of Man to Environmental Nickel - An Exposure Commitment Assessment," The Scien:" of the Total Environment, 22:203-212.

Bennett, B.G., 1981, Exposure Commitment Assessments of Environmental Pollutants, report 23, MARC.

Bignoli, G., 1989, "Health and Environmental Impact of Chromium Released from Coal Ash," Journal of Coal Quality, 8:3-4, 72-81, July-Dec.

Boutacoff, D., 1991, "The Question of Airborne Toxics," EPRI Journal, pp. 5-13, Mar.

Breger, I.A., et al., 1955a, "Geochemistry and Mineralogy of a Uraniferous Subbituminous Coal," Economic Geology, 50:610-624.

Breger, I.A., et al., 1955b, "Geochemistry and Mineralogy of a Uraniferous Lignite," Economic Geology, 50:206-226. 
Brown, T.D., et al., 1991, "Comprehensive Assessment of Toxic Emissions from Coal-Fired Power Plants," prepared for presentation at the Conference on Managing Hazardous Air Pollutants: State of the Art, sponsored by the EPRI, Palo Alto, Calif., held in Washington, D.C., Nov. 4-6.

Cadle, R.D., et al., 1973, "Trace Constituents Emitted to the Atmosphere by Hawaiian Volcanoes," Chemosphere, (6):231-234.

Caruccio, F.T., 1972, "Trace Element Distribution in Reactive and Inert Pyrite," proceedings of the Fourth Symposium on Coal Mine Drainage Research, Carnegie Mellon Institute, Pittsburgh, Penn., pp. 48-54.

Cherchar, 1985, Etude des Conditions de Formation et d'Evolution des Polluants en Traces Lors de la Combustion du Charbon dans les Foyers Industriels (Study of the Formation Conditions and Evolution of Trace Pollutants from Coal Combustion in Industrial Boilers), Commission of the European Communities, report EUR 9659 FR, Brussels, Belgium.

Clarke, L.B., 1991, "The Behavior of Trace Elements during Coal Combustion and Gasification: An Overview," presented at the Conference on Managing Hazardous Air Pollutants: State of the Art, sponsored by the EPRI, Palo Alto, Calif., held in Washington, D.C., Nov. 4-6.

Clarke, L.B., and L.L. Sloss, 1992, Trace Element Emissions from Coal Combustion and Gasification, report IEACR/49, IEA Coal Research, London, England, July.

Coenen, R., 1985, Steinkohle - Technikfolgenabschatzung Ihres Verstarkten Einsatzes in der Bundesrepublik Deutschland (Hard Coal - Evaluation of the Technical Consequences for its Increased Use in the FRG), Springer-Verlag, Berlin, Federal Republic of Germany.

Collins, S., 1990, "Can Problems Arising from Chlorine in Coal Be Solved Generically?" Power, Dec., 59-60.

Conzemius, R.J., et al., 1984, "Elemental Partitioning in Ash Depositories and Material Balances for a Coal Burning Facility by Spark Source Mass Spectrometry," Environmental Science and Technology, 18(1):12-18.

Cooke, T.D., and K.W. Bruland, 1987, "Aquatic Chemistry of Selenium: Evidence of Biomethylation," Environmental Science Technology, 21:1214-1219.

Corbett, J.O., 1983, "The Radiation Dose from Coal Burning: A Review of Pathways and Data," Radiation Protection Dosimetry, 4:5-19.

Daniel, W.W., and J.C. Terrell, 1983, Business Statistics: Basic Concepts and Methodology, 3rd ed., Houghton Mifflin Company, Boston, Mass.

Deurbrouck, A.W., and P.S. Jacobsen, 1974, "Coal Cleaning: State of the Art," Conference on Coal and the Environment, Louisville, Ky., Oct. 22. 
DHHS: See U.S. Department of Health and Human Services/U.S. DHHS.

Diehl, R.C., et al., 1972, Fate of Trace Mercury in the Combustion of Coal, technical program report 54, U.S. Bureau of Mines, Washington, D.C.

DOE: See U.S. Department of Energy/U.S. DOE.

Dvornikov, A.G., 1981a, "Forms of Mercury Occurrence in Coals of the Donets Basin," abstract, Chemical Abstracts, 95:135456.

Dvornikov, A.G., 1981b, "Forms of Mercury in Donets Basin Coals," abstract, Chemical Abstracts, 95:135454.

EPA: See U.S. Environmental Protection Agency/U.S. EPA.

Eschenroeder, A.Q., et al., 1985, Assessing the Health Risks of Airborne Carcinogens, EPRI report EA-4021, prepared by Arthur D. Little, Cambridge, Mass., for Electric Power Research Institute, Palo Alto, Calif., May.

Eshleman, A., et al., 1971, "Is Mercury from Hawaiian Volcanoes a Natural Source of Pollution?" Nature, 233:471-472.

Finkelman, R.B., 1988, "The Inorganic Geochemistry of Coal: A Scanning Electron Microscopy View," Scanning Microscopy, 2(1):97-105.

Finkelman, R.B., 1981, Modes of Occurrence of Trace Elements in Coal, open file report OFR81-99, U.S. Geological Survey, Reston, Va., also Ph.D. thesis, University of Maryland, College Park, Md.

Finkelman, R.B., et al., 1979, "Modes of Occurrence of Selected Trace Elements in Several Appalachian Coals," American Chemical Society Division, Fuel Chemistry Preprint, $24(1): 236-241$.

Fishbein, L., 1981, "Sources, Transport, and Alterations of Metal Compounds: An Overview: Arsenic, Beryllium, Cadmium, Chromium, and Nickel," Environmental Health Perspectives, 40:43-64.

Fukuzaki, N., et al., 1986, "Mercury Emission from a Cement Factory and Its Influence on the Environment," Atmospheric Environment, 20:2291-2299.

Gay, A.J., and A.P. Von Rosenstiel, 1982, A Study of the Composition and Morphology of Fly Ash from Coal-Burning Installations, final report CL 82/55, Jan. 1980-Dec. 1981, The Hague, The Netherlands. 
Gill, D.W., and R.F. Littlejohn, 1980, "Technical/Economic Evaluation of the Methods to Diminish Emissions," in Study into the Emission of Air Pollutants Coming from the Use of Coal within the U.K., report no. EUR 6853, Commission of the European Communities, Luxembourg, pp. 109-219.

Given, P.H., and R.N. Miller, 1987, "The Association of Major, Minor, and Trace Inorganic Elements with Lignites," Geochimica Cosmochimica Acta, 51:1843-1853.

Gladney, E.S., and J.W. Owens, 1976, "Beryllium Emissions from a Coal-Fired Power Plant," Journal of Environmental Science and Health, A11:297-311.

Gluskoter, H.J., 1975, "Mineral Matter and Trace Elements in Coal," chap. 1 in Trace Elernents in Fuel, S.P. Babu (editor), Advances in Chemistry Series, no. 141, American Chemical Society, Washington, D.C.

Gluskoter, H.J., and P.C. Lindahl, 1973, "Cadmium - Mode of Occurrence in Illinois Coals," Science, 188:264-266.

Gluskoter, H.J., and O.W. Rees, 1964, Chlorine in Illinois Coal, circular 372, Illinois State Geological Survey, Champaign, Ill.

Gluskoter, H.J., and R.R. Ruch, 1971, "Chlorine and Sodium in Illinois Coals as Determined by Neutron Activation Analyses," Fuel, 50:65-76.

Gluskoter, H.J., et al., 1977, Trace Elements in Coal: Occurrence and Distribution, circular 499, Illinois State Geological Survey, Champaign, Ill.

Greenland, L.P., and E.P. Aruscavage, 1986, "Volcanic Emission of Selenium, Tellurium, and Arsenic from Kilanea Volcano, Hawaii," Journal of Volcanology and Geothermal Research, 27:195-201.

Hawley, G.G., 1977, The Condensed Chemical Dictionary, 9th ed., Van Nostrand Reinhold Company, New York, N.Y.

Henderson, J.A., et al., 1985, Analyses of Virginia Coal Samples Collected 1978-1980, publication 63, Virginia Division of Mineral Resources, Reston, Va.

Highley, J., 1985, Atmospheric FBC and CFB: the European Approach, proceedings of the Advanced Coal Power Technology Symposium, held in Malmo, Sweden, Nov. 6-7, sponsored by the Sydkraft Research Foundation, Mulmo, Sweden.

Hobbs, C.H., 1983, Status of Research on Physical, Chemical, and Biological Characterization of Particulate and Organic Emissions from Conventional and Fluidized Bed Combustion of Coal: 1976 to the Present, report DOE/ER-0162, prepared by Inhalation Toxicology Research Institute, Albuquerque, N.M., for U.S. Department of Energy, Washington, D.C., Apr. 
Hodges, N.J., et al., 1983, "Chlorine in Coal: A Review of Its Origin and Mode of Occurrence," Journal of the Institute of Energy, 56:158-169.

Hootman, H.A., and J.E. Vernet, 1991, Air Toxics Provisions of the Clean Air Act: Potential Impacts on Energy, report ANL/EAIS/TM-66, Argonne National Laboratory, Argonne, Ill., Nov.

Jacobi, W., et al., 1982, "Comparison of Radiation Exposure from Coal-Fired and Nuclear Power Plants in the Federal Republic of Germany," abstract, Chemical Abstracts, 98:97558 (1983).

Joensuu, O.I., 1971, "Fossil Fuels as a Source of Mercury Pollution," Science, 172:1027-1028.

Kama, W., and S.M. Siegel, 1980, "Volatile Mercury Release from Vascular Planis," Organic Geochemistry, 2:99-101.

Kirsch, H., et al., 1980, "The Origin of the Trace Elements Zinc, Cadmium, and Vanadium in Bituminous Coals and Their Behavior During Combustion," VGB Kraftwerkstechnik, 60:734-744.

Klein, D.H., et al., 1975, "Pathways of Thirty-Seven Trace Elements through a Coal-Fired Power Plant," Environmental Science and Technology, 9(10):973-979.

Lag, J., and E. Steinnes, 1978, "Regional Distribution of Selenium and Arsenic in Humus Layers of Norwegian Forest Soils," Geoderma, 20:3-14.

Levander, O.A., 1987, "A Global View of Human Selenium Nutrition," Annual Review of Nutrition, 7:227-250.

Lightowlers, P.J., and J.N. Cape, 1988, "Sources and Fate of Atmospheric HCl in the U.K. and Western Europe," Atmospheric Environment, 22:7-15.

Mann, R.M., et al., 1991, "Air Toxics Monitoring Issues," EPRI Journal, 5-13, May.

Marczak, M., and H. Parzentny, 1985, "Geochemical and Ecological Evaluation of High-Lead Coal from the Chelm Deposit," abstract, IEA Coal Abstracts, 10:7521 (1986).

Martinez-Tarazona, M.R., et al., 1988, "The Mode of Occurrence of Chlorine in High Volatile Bituminous Coals from the Asturian Central Coalfield," Fuel, 67:1624-1628.

McCarroll, J., 1980, "Health Effects Associated with Increased Use of Coal," Journal of the Air Pollution Control Association, 30:652-656.

Meij, R., 1991, personal communication from Meij (Netherlands Agency for Energy and the Environment [NOVEM], Utrecht, The Netherlands), to L.L. Sloss, (IEA Coal Research, London, England), Mar. 
Meij, R., 1989, "Tracking Trace Elements at a Coal-Fired Power Plant Equipped with a WetFlue-Gas Desulfurization Facility," KEMA Scientific and Technical Reports, special issue, 7(5):267-355.

Merritt, R.I., 1988, "General Trends in Major, Minor, and Trace Elements in Coal with a Comparative Profile of Alaskan Coal," Journal of Coal Quality, 7(3):95-103.

Minkin, J.A., et al., 1984, "Microcharacterization of Arsenic- and Selenium-Bearing Pyrite in Upper Freeport Coal, Indiana County, Pennsylvania," Scanning Electron Microscopy, (4)15151524.

Mishra, U.C., et al., 1984, "Relative Radiation Hazards of Coal-Based and Nuclear Power Plants in India," Radiation Risk, proceedings of the 6th international conference, 1:537-540.

Mojtahedi, W., 1989, "Trace Metals Volatilization in Fluidized-Bed Combustion and Gasification of Coal," Combustion Science and Technology, 63:209-227.

Mosher, B.W., and R.A. Duce, 1983, "Vapor Phase and Particulate Selenium in the Marine Atmosphere," Journal of Geophysical Research, 88(C11):6761-6768.

National Research Council, 1977, Drinking Water and Health, National Academy of Sciences, Washington, D.C.

Natusch, D.F.S., 1978, "Potentially Carcinogenic Species Emitted to the Atmosphere by Fossil-Fueled Power Plants," Environmental Health Perspectives, 22:79-90, Feb.

Nriagu, J.O., 1990, "Global Metal Pollution: Poisoning the Biosphere?" Environment, 32(7):7-33, Sept.

Nriagu, J.C., 1979, "Global Inventory of Natural and Anthropogenic Emissions of Trace Metals to the Atmosphere," Nature, 279:409-411.

Nriagu, J.O., et al., 1988, "Distribution and Characteristic Features of Chromium in the Atmosphere," in Chromium in the Natural and Human Environments, J.O. Nriagu and E. Nieboer (editors), John Wiley \& Sons, Inc., New York, N.Y.

O'Gorman, J.V., and P.L. Walker, Jr., 1972, Mineral Matter and Trace Elements in U.S. Coals, R\&D report 61 , interim report 2, U.S. Department of the Interior, Office of Coal Research, Washington, D.C.

O'Gorman, J.V., and P.L. Walker, Jr., 1971, "Mineral Matter Characteristics of Some American Coals," Fuel, 50(2):135-51.

Oman, C.L., et al., 1988, Selenium in Coals from the Powder River Basin, Wyoming and Montana, circular 1025, U.S. Geological Survey, Reston, Va. 
Pacyna, J.M., 1983, Trace Element Emission from Anthropogenic Sources in Europe, report NILU TR 10/82, Norwegian Institute for Air Research, Lillestrom, Norway, Feb.

Pacyna, J.M., et al., 1984, "Emissions and Long-Range Transport of Trace Elements in Europe," Tellus, 36(3):163-178.

Patterson, C.C., and D.M. Settle, 1987, "Magnitude of Lead Flux to the Atmosphere from Volcanoes," Geochimica Cosmochimica Acta, 51:675-681.

Porritt, R.E., and D.J. Swaine, 1976, "Mercury and Selenium in Some Australian Coals and Fly Ash," in proceedings of the Australian Institute of Fuel Conference, Sydney, New South Wales, pp. 18.1-18.9.

Public Health Service: See U.S. Department of Health and Human Services/U.S. DHHS.

Rao, C.P., and H.J. Gluskoter, 1973, Occurrence and Distribution of Minerals in Illinois Coals, circular 476, Illinois State Geological Survey, Champaign, Ill.

Ruch, R.R., et al., 1974, Occurrence and Distribution of Potentially Volatile Trace Elements in Coal, environmental geological notes 72, Illinois State Geological Survey, Champaign, Ill., Aug.

Ruch, R.R., et al., 1971, Mercury Content of Illinois Coals, environmental notes 43, Illinois State Geological Survey, Champaign, Ill.

Sabbioni, E., and L. Goetz, 1983, Mobilization of Heavy Metals from Fossil-Fuelled Power Plants, Potential Ecological and Biochemical Implications, Part 4, Assessment Studies of the European Situation, PB84-211770, EUR-6998EN Part IV, Commission of the European Communities, Luxembourg.

Salmon, L., et al., 1984, "The Radioactivity Content of U.K. Coal," The Science of the Total Environment, 35:403-415.

Saunders, K.G., 1980, "Microstructural Studies of Chlorine in Some British Coals," Journal of the Institute of Energy, 53:109-115.

Schobert, H.H., 1987, Coal: The Energy Source of the Past and Future, American Chemical Society, Washington, D.C.

Schroeder, H.A., 1967, Circulation, 35:570.

Schultz, H., et al., 1975, "Fate of Some Trace Elements During Coal Pretreatment and Combustion," chap. 11 in Trace Elements in Fuel, S.P. Babu (editor), Advances in Chemistry Series, no. 141, American Chemical Society, Washington, D.C.

Slemr, F., and E. Langer, 1992, "Increase in Global Atmospheric Concentrations of Mercury Inferred from Measurements over the Atlantic Ocean," Nature, 355:434-436, Jan. 
Sloss, L.L., 1992, Halogen Emissions from Coal Combustion, IEA Coal Research, London, England.

Smith, 1987, Trace Elements from Coal Combustion: Emissions, report IEACR/01, IEA Coal Research, London, England, June.

Spackman, W., 1982, The Characteristics of American Coals in Relation to Their Conversion into Clean-Energy Fuels, Final Report Appendices VIII A and B, DOE/ET/10615,17-App. 8A and $8 \mathrm{~B}$, June.

Swaine, D.J., 1990, Trace Elements in Coal, Butterworths, London, England.

Swaine, D.J., 1984, The Fate of Trace Elements During Combustion, proceedings of the Australian Coal Science Conference, Gippsland Institute for Advanced Education, Churchill, Vic.

Swaine, D.J., 1982, "The Importance of Trace Elements in Australian Coals," Energy News Journal, 4(3):18-22.

Swaine, D.J., 1977, Trace Elements in Fly Ash, bulletin 218, New Zealand Department of Scientific and Industrial Research.

Swaine, D.J., et al., 1988, "The Deposition of Trace Elements from the Atmosphere," in Trace Elements in New Zealand: Environmental, Human, and Animal, proceedings of the New Zealand Trace Elements Group Conference, Canterbury, New Zealand, pp. 1-10.

Swanson, V.E., et al., 1976, Collection, Chemical Analysis, and Evaluation of Coal Samples in 1975, open file report 76-468, U.S. Department of the Interior, U.S. Geological Survey, Reston, Va.

Szpunar, C.B., et al., 1980, The Fate of Trace Elements in Coal Combustion, report COR.24KW.80, Exxon Research and Engineering, Baytown, Texas, Dec.

Thiessen, G., et al., 1936, "Coal Ash and Coal Mineral Matter," Industrial and Engineering Chemistry Research, 28:355-61.

U.S. Congress, 1990, "Clean Air Act as Amended," Public Law 101-549.

U.S. Department of Energy (DOE), 1992, Request for Proposal - Comprehensive Assessment of Toxic Emissions from Coal-Fired Power Plants, Attachment A, DE-RP22-92PC91349, Pittsburgh Energy Technology Center, Pittsburgh, Penn., Jan.

U.S. DOE, 1989, International Energy Annual: 1988, report DOE/EIA-0219(88), Energy Information Administration, Washington, D.C.

U.S. DOE, 1987, Coal Supply and Transportation Model (CSTM) Model Description, report DOE/EIA-0401, Energy Information Administration, Washington, D.C., June. 
U.S. Department of Health and Human Services (DHHS), 1990a, Toxicological Profile for Lead, ATSDR/TP-88/17, Public Health Service, Agency for Toxic Substances and Disease Registry, Washington, D.C., prepared by Syracuse Research Corporation, Arlington, Va., in collaboration with the U.S. EPA, Washington, D.C., June.

U.S. DHHS, 1990b, Toxicological Profile for Antimony and Compounds, draft, Public Health Service, Agency for Toxic Substances and Disease Registry, Washington, D.C., prepared by Syracuse Research Corporation, Arlington, Va., under contract to Clement Associates, Inc., Los Altos, Calif., Oct.

U.S. DHHS, 1990c, Toxicological Profile for Cobalt, draft, Public Health Service, Agency for Toxic Substances and Disease Registry, Washington, D.C., prepared by Syracuse Research Corporation, Arlington, Va., under subcontract to Clement Associates, Inc., Los Altos, Calif., Oct.

U.S. DHHS, 1990d, Toxicological Profile for Manganese and Compounds, draft, Public Health Service, Agency for Toxic Substances and Disease Registry, Washington, D.C., prepared by Life Systems, Inc., Dallas, Texas, under subcontract to Clement Associates, Inc., Los Altos, Calif., Oct.

U.S. DHHS, 1990e, Toxicological Profile for Thorium, draft TP-90-25, Public Health Service, Agency for Toxic Substances and Disease Registry, Washington, D.C., prepared by Syracuse Research Corporation, Arlington, Va., under subcontract to Clement Associates, Inc., Los Altos, Calif., in collaboration with the U.S. EPA, Washington, D.C., Oct.

U.S. DHHS, 1990f, Toxicological Profile for Hexachlorobenzene, Public Health Service, Agency for Toxic Substances and Disease Registry, Washington, D.C., prepared by Life Systems, Inc., Dallas, Texas, under subcontract to Clement Associates, Inc., Los Altç, Calif., Dec.

U.S. DHHS, 1990g, Toxicological Profile for Naphthalene and 2-Methylnaphthalene, TP-90-18, Public Health Service, Agency for Toxic Substances and Disease Registry, Washington, D.C., prepared by Life Systems, Inc., Dallas, Texas, under subcontract to Clement Associates, Inc., Los Altos, Calif., Dec.

U.S. DHHS, 1990h, Toxicological Profile for Polycyclic Aromatic Hydrocarbons, TP-90-20, Public Health Service, Agency for Toxic Substances and Disease Registry, Washington, D.C., prepared by Clement Associates, Inc., Los Altos, Calif., Dec.

U.S. DHHS, 1990i, Toxicological Profile for Radon, TP-90-23, Public Health Service, Agency for Toxic Substances and Disease Registry, Washington, D.C., prepared by Clement Associates, Inc., Los Altos, Calif., in collaboration with the U.S. EPA, Washington, D.C., Dec.

U.S. DHHS, 1990j, Toxicological Profile for Uranium, TP-90-29, Public Health Service, Agency for Toxic Substances and Disease Registry, Washington, D.C., prepared by Syracuse Research Corporation under subcontract to Clement Associates, Inc., Los Altos, Calif., in collaboration with the U.S. EPA, Washington, D.C., Dec. 
U.S. DHHS, 1989a, Toxicological Profile for Chloroform, ATSDR/TP-88/09, Public Health Service, Agency for Toxic Substances and Disease Registry, Washington, D.C., prepared by Syracuse Research Corporation, Arlington, Va., in collaboration with the U.S. EPA, Washington, D.C., Jan.

U.S. DHHS, 1989b, Toxicological Profile for Arsenic, ATSDR/TP-88/02, Public Health Service, Agency for Toxic Substances and Disease Registry, Washington, D.C., prepared by Life Systems, Inc., Dallas, Texas, in collaboration with the U.S. EPA, Washington, D.C., March.

U.S. DhitS, 1989c, Toxicological Profile for Cadmium, ATSDR/TP-88/08, Public Health Service, Agency for Toxic Substances and Disease Registry, Washington, D.C., prepared by Life Systems, Inc., Dallas, Texas, in collaboration with the U.S. EPA, Washington, D.C., March.

U.S. DHHS, 1989d, Toxicological Profile for Benzene, ATSDR/TP-88/03, Public Health Service, Agency for Toxic Substances and Disease Registry, Washington, D.C., prepared by Oak Ridge National Laboratory, Oak Ridge, Tenn., in collaboration with the U.S. EPA, Washington, D.C., May.

U.S. DHHS, 1989e, Toxicological Profile for Chromium, ATSDR/TP-88/10, Public Health Service, Agency for Toxic Substances and Disease Registry, Washington, D.C., prepared by Syracuse Research Corporation, Arlington, Va., in collaboration with the U.S. EPA, Washington, D.C., July.

U.S. DHHS, 1989f, Toxicological Profile for Benzidene, Public Health Service, Agency for Toxic Substances and Disease Registry, Washington, D.C., prepared by Life Systems, Inc., Dallas, Texas, under subcontract to Clement Associates, Inc., Los Altos, Calif., in collaboration with the U.S. EPA, Washington, D.C., Dec.

U.S. DHHS, 1989g, Toxicological Profile for Carbon Tetrachloride, Public Health Service, Agency for Toxic Substances and Disease Registry, Washington, D.C., prepared by Life Systems, Inc., Dallas, Texas, under subcontract to Clement Associates, Inc., Los Altos, Calif., in collaboration with the U.S. EPA, Washington, D.C., Dec.

U.S. DHHS, 1989h, Toxicological Profile for Mercury, Public Health Service, Agency for Toxic Substances and Disease Registry, Washington, D.C., prepared by Clement Associates, Inc., Los Altos, Calif., in collaboration with the U.S. EPA, Washington, D.C., Dec.

U.S. DHHS, 1989i, Toxicological Profile for Phenol, Public Health Service, Agency for Toxic Substances and Disease Registry, Washington, D.C., prepared by Syracuse Research Corporation, Arlington, Va., under subcontract to Clement Associates, Inc., Los Altos, Calif., in collaboration with the U.S. EPA, Washington, D.C., Dec.

U.S. DHHS, 1989j, Toxicological Profile for Selenium, Public Health Service, Agency for Toxic Substances and Disease Registry, Washington, D.C., prepared by Clement Associates, Inc., Los Altos, Calif., in collaboration with the U.S. EPA, Washington, D.C., Dec. 
U.S. DHHS, 1989k, Toxicological Profile for Toluene, Public Health Service, Agency for Toxic Substances and Disease Registry, Washington, D.C., prepared by Life Systems, Inc., Dallas, Texas, under subcontract to Clement Associates, Inc., Los Altos, Calif., in collaboration with the U.S. EPA, Washington, D.C., Dec.

U.S. DHHS, 1988a, Toxicological Profile for Trichloroethylene, draft, Public Health Service, Agency for Toxic Substances and Disease Registry, Washington, D.C., prepared by Technical Resources, Inc., Rockville, Md., revised by Syracuse Research Corporation, Arlington, Va., in collaboration with the U.S. EPA, Washington, D.C., Jan.

U.S. DHHS, 1988b, Toxicological Profile for Beryllium, ATSDR/TP-88/07, Public Health Service, Agency for Toxic Substances and Disease Registry, Washington, D.C., prepared by Syracuse Research Corporation, Arlington, Va., in collaboration with the U.S. EPA, Washington, D.C., Dec.

U.S. DHHS, 1988c, Toxicological Profile for Nickel, ATSDR/TP-88/19, Public Health Service, Agency for Toxic Substances and Disease Registry, Washington, D.C., prepared by Syracuse Research Corporation, Arlington, Va., in collaboration with the U.S. EPA, Washington, D.C., Dec.

U.S. DHHS, 1987, Toxicological Profile Report for 2,3,7,8-Tetrachlorodibenzo-p-dioxin, draft, Public Health Service, Agency for Toxic Substances and Disease Registry, Washington, D.C., prepared by Syracuse Research Corporation, Arlington, Va., Nov.

U.S. Environmental Protection Agency (EPA), 1992, "Part IV, Environmental Protection Agency, Initial List of Categories of Sources Under Section 112(c)(1) of the Clean Air Act Amendments of 1990; Notice," Federal Register, 57(137):31576-31592, July 16.

U.S. EPA, 1991, Revised Criteria for Selecting High-Risk Pollutants for the Purposes of the Clean Air Act, Section 112(i)(5)(E), internal memorandum by B.M. Hassett-Sipple, May.

U.S. EPA, 1990a, Documentation for Developing the Source Category List, preliminary draft, Office of Air Quality Planning and Standards, Research Triangle Park, N.C., Dec.

U.S. EPA, 1990b, Cancer Risk from Outdoor Exposure to Air Toxics, EPA-450/1-90-004a, Office of Air Quality Planning and Standards, Research Triangle Park, N.C., Sept.

U.S. EPA, 1989, Estimating Air Toxics Emissions from Coal and Oil Combustion Sources, EPA-450/2-89-001, Office of Air Quality Planning and Standards, Research Triangle Park, N.C., April.

Varekamp, J.C., and P.R. Buseck, 1986, "Global Mercury Flux from Volcanic and Geothermal Sources," Applied Geochemistry, 1:65-73.

Wagner, P., et al., 1980, Radioactive Emissions from Coal Production and Utilization, progress report, (NTIS no. LA-8618-PR), U.S. Department of Energy, Washington, D.C. 
Walsh, P.R., et al., 1979, "Considerations of the Enrichment, Sources, and Flux of Arsenic in the Troposphere," Journal of Geophysical Research, 84(C4)1719-1726.

Wandless, A.M., 1958, "British Coal Seams: A Review of Their Properties with Suggestions for Research," conference proceedings, Science in the Use of Coal, Sheffield, England, pp. A1-A12.

Warman, K., 1984, PAH Emissions from Coal-Fired Plants, (NTIS no. DE85 750375), Studsvik Energiteknik AB, Nykoeping, Sweden, Jan.

Wewerka, E.M., e'c al., 1976, Environmental Contamination from Trace Elements in Coal Preparation Was'es: A Literature Review and Assessment, ERDA LA-6600-MS and EPA-600/776-007, prepared for U.S. EPA Office of Research and Development and U.S. ERDA Office of Assistant Administrator for Environment and Safety, Aug.

White, D.M., et al., 1984, Correlation of Coal Properties with Environmental Control Technology Needs for Sulfur and Trace Elements, EPA-600/7-84-066, Radian Corp., Austin, Texas, June.

White, D.M., et al., 1983, Trace Elements in Texas Lignite, report TENRAC/EDF-094 (NTIS no. DE84900413), Radian Corporation, Austin, Texas, Aug.

Yokoyama, T., et al., 1991, Field Study of Trace Elements Behavior in Coal-Fired Plants, report no. ET 91002, Komae Research Laboratory, Komae, Japan, CRIEPI, Aug.

Zelenski, S.G., et al., 1980, Inventory of Organic Emissions from Fossil Fuel Combustion for Power Generation, EPRI EA-1394, TPS 78-820, prepared for Electric Power Research Instituto, Palo Alto, Calif., Apr.

Zieve, R., and P.J. Peterson, 1984, "Volatilization of Selenium from Plants and Soils," Science of the Total Environment, 32:197-202.

Zubovic, P., 1966a, "Physicochemical Properties of Certain Minor Elements as Controlling Factors in Their Distribution in Coal," Advances in Chemistry Series, no. 55, American Chemical Society, Washington, D.C., pp. 221-30.

Zubovic, P., 1966b, "Eastern Interior Coals," Advanced Chemistry Series, no. 55, American Chemical Society, Washington, D.C., pp. 232-247.

Zubovic, P., et al., 1979, Assessment of the Chemical Composition of Coal Resources, report TCD/NRET/AC.12/EP/15, U.N. Symposium World Coal Prospects, United Nations, New York, N.Y.

Zubovic, P., et al., 1967, Distribution of Minor Elements in Some Coals in the Western and Southwestern Regions of the Interior Coal Province, bullein 1117-D, U.S. Geological Survey, Reston, Va. 
Zubovic P., et al., 1966, Distribution of Minor Elements in Coals of the Appalachian Region, bulletin 1117-C, U.S. Geological Survey, Reston, Va.

Zubovic, P., et al., 1964, Distribution of Minor Elements in Coal Beds of the Eastern Interior Region, bulletin 1117-B, U.S. Geological Survey, Reston, Va.

Zubovic, P., et al., 1961, Geochemistry of Minor Elements in Coals of the Northern Great Plains Coal Province, bulletin 1117-A, U.S. Geological Survey, Reston, Va.

Zubovic, P., et al., 1960, Comparative Abundance of the Minor Elements in Coals from Different Parts of the United States, professional paper 400-B, pp. B87-B88, U.S. Geological Survey, Reston, Va. 


\section{BIBLIOGRAPHY}

Averitt, P., et al., 1976, Minor and Trace Elements in Coal: A Selected Bibliography of Reports in English, open file report 76-481, U.S. Geological Survey, Reston, Va.

Bethell, F.V., 1963, Journal of the Institute of Fuel, 36:478-92 (distribution of elements in coal published prior to 1962 with more than 200 references).

Boni, A.A., et al., 1990, Transformations of Inorganic Coal Constituents in Combustion Systems, Part 1, Sections 1-6, PSI Technology Co., Andover, Mass., DOE/PC/90751-T4-Pt.1, Mar.

Electric Power Alert, 1992, Environmental Adders: Advisory Group Study Targets Impact of State Externality Rules on Coal, p. 17, Feb. 19.

Hall, J.V., et al., 1992, "Valuing the Health Benefits of Clean Air," Science, 255: Feb. 14.

Harrison, C.D., and J.D. Hervol, 1989, Proceedings: Reducing Power Plant Emissions by Controlling Coal Quality, EPRI GS-6281, prepared for Electric Power Research Institute by Writing Consultants Associated, Pittsburgh, Penn., Oct.

Kowalczyk, G.S., et al., 1988, Emissions of Air Toxics from a Coal-Fired Power Plant, Annual Meeting of Air Pollution Control Association in Dallas, Texas, June 19-24, Air Pollution Control Association, Pittsburgh, Penn.

Magee, E.M., et al., 1973, Potential Pollutants in Fossil Fuels, U.S. EPA Technological Ser., report EPA-R2-73-249 (excellent review of potential pollutants in fossil fuels with special attention to $\mathrm{Hg}$ and $\mathrm{S})$.

Mitchell, D.L., and B.L. Wilson, 1987, A Trace Metal Study Surrounding a Coal-Fired Electrical Generating Facility, CONF-870436-2 (DOE microfiche DE88-014918), Texas Southern University, Dept. of Chemistry, Houston, Texas.

Organization for Cooperation and Development (OECD), 1987, Energy and Cleaner Air: Costs of Reducing Emissions, Paris, France.

OECD, 1985, Environmental Effects of Electricity Generation, Paris, France.

Schmidt, C., 1991, "Air Toxics and the 1990 Clean Air Act," PETC Review, pp. 26-31, Mar.

U.S. Department of Energy, 1986, Estimating Environmental Costs and Benefits for Five Generating Resources, Bonneville Power Administration, April.

U.S. Environmental Protection Agency, 1989, Toxics-Release Inventory: A National Perspective, 1987, (NTIS no. PB89-208144), Washington, D.C., June. 
U.S. EPA, 1976, EPA Program Conference Report Fuel Cleaning Program: Coal, (NTIS no. PB-262 876), Washington, D.C., Oct.

U.S. Geological Survey, 1976, Minor and Trace Elements in Coal: A Selected Bibliography of Reports in English, (microfiche USGS-OFR-76-481), U.S. Geological Survey, Washington, D.C., Jan.

Watt, J.D., 1968, "The Physical and Chemical Behavior of the Mineral Matter in Coal under the Conditions Met in a Combustion Plant," in The Occurrence, Origin, Identity, Distribution, and Estimation of the Mineral Species in British Coals, Part 1, British Coal Utilization Research Assoc., Leatherhead, Surrey, England (not limited to minerals in coal or to British coals). 

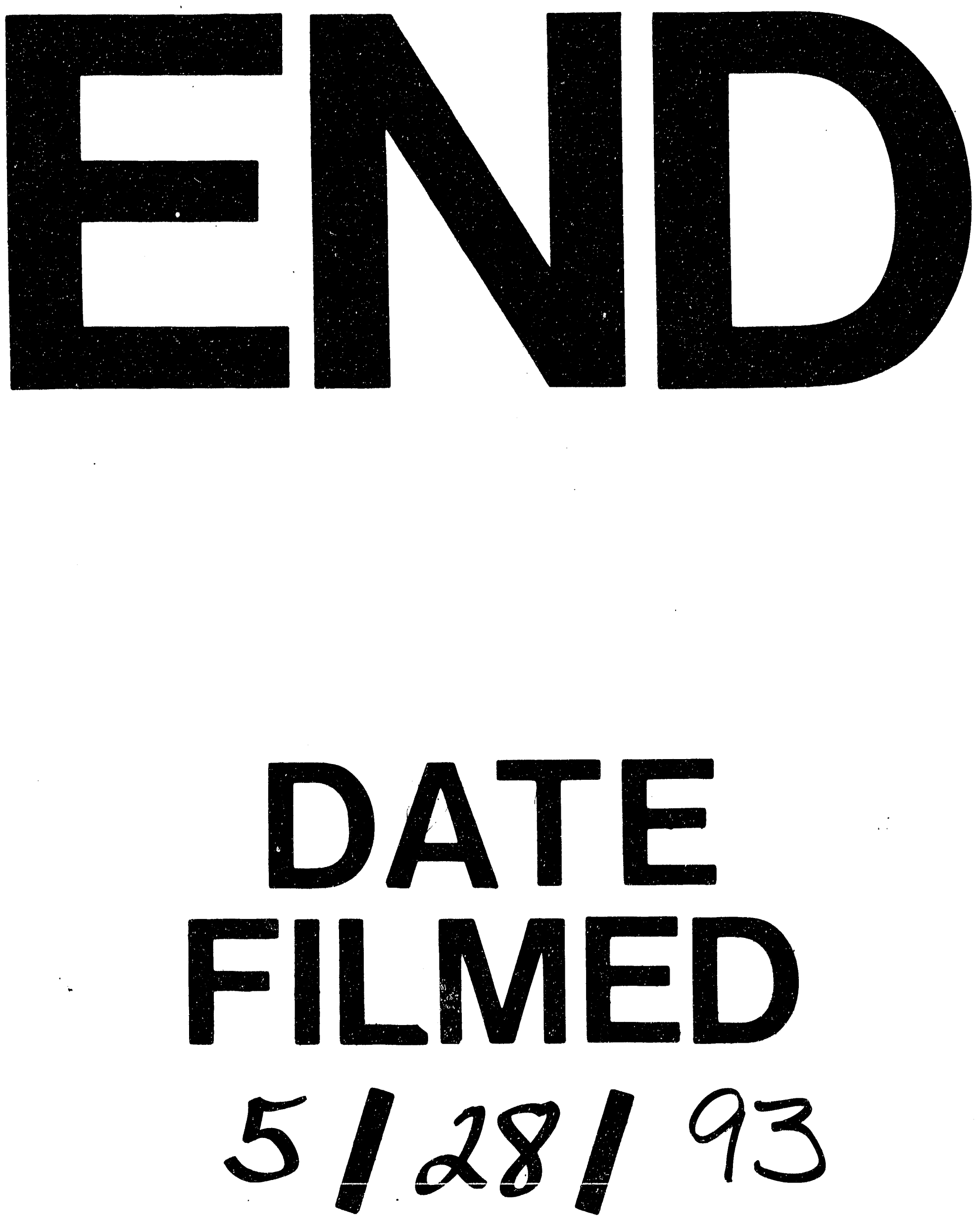

( 
